ANA SHITARA INGLESI

\title{
A leitura nas organizações não-governamentais e inter-relações com a escola pública: \\ um estudo de caso
}

Dissertação apresentada à Faculdade de Educação da Universidade de São Paulo para a obtenção do título de Mestre em Educação.

Área Temática: Linguagem e Educação

Orientadora: Profa. Dra. Idméa Semeghini-Siqueira

SÃo PAULO

2008 
Autorizo a reprodução e divulgação total ou parcial deste trabalho, por qualquer meio convencional ou eletrônico, para fins de estudo e pesquisa, desde que citada a fonte.

Catalogação na Publicação

Serviço de Biblioteca e Documentação

Faculdade de Educação da Universidade de São Paulo

372.4 Shitara-Inglesi, Ana

I51L A leitura nas organizações não-governamentais e interrelações com a escola pública : um estudo de caso / Ana Shitara-Inglesi; orientação Idméa Semeghini-Siqueira. São Paulo : s.n., 2008.

282 p. il., grafs. tabs.

Dissertação (Mestrado - Programa de Pós-Graduação em Educação.Área de Concentração : Linguagem e Educação) - Faculdade de Educação da Universidade de São Paulo.

1. Leitura 2. Organização não-governamental 3. Educação não formal 4. Letramento 5. Escola pública 6. Políticas públicas Educação I. Semeghini-Siqueira, Idméa, orient. 


\section{FOLHA DE APROVAÇÃO}

\section{Ana Shitara Inglesi}

A leitura nas organizações não-governamentais e inter-relações com a escola pública: um estudo de caso.

Dissertação apresentada à Faculdade de Educação da Universidade de São Paulo para a obtenção do título de Mestre em Educação.

Área Temática: Linguagem e Educação

Aprovado em:

Banca Examinadora

Prof. Dr.

Instituição: Assinatura:

Prof. Dr.

Instituição: Assinatura:

Prof. Dr. Instituição: Assinatura: 


\section{DEDICATÓRIA}

Aos meus pais, Koji e Dulce, pelo amor, apoio e estímulo nos momentos decisivos.

À Tetê por ter me dado alegria de viver, quando eu mais precisei.

Ao Marco, meu esposo, com amor e gratidão por sua compreensão, carinho, presença e apoio ao longo do período de elaboração deste trabalho e durante todo o nosso convívio. 
À Professora Doutora Idméa Semeghini-Siqueira que, nos anos de convivência, muito me ensinou, contribuindo para o meu crescimento científico e intelectual, tratando-me com muito carinho e respeito. Uma verdadeira Professora: aquela que estimula e aumenta a autoestima de seus alunos, os fazendo acreditar que podem sempre aprender e melhorar.

À Professora Shoko Kimura, pela atenção, sinceridade, estímulo e risadas durante o processo de definição e orientação.

À ONG 6 e seus participantes pela oportunidade de realização da pesquisa, por se colocarem à disposição de braços abertos, sempre facilitando e colaborando com o trabalho da pesquisadora. 


\section{RESUMO}

SHITARA-INGLESI, A. A leitura nas organizações não-governamentais e inter-relações com a escola pública: um estudo de caso. 2008, 286 f. Dissertação (Mestrado) - Faculdade de Educação, Universidade de São Paulo, São Paulo, 2008.

Tendo em vista o baixo grau de letramento entre os alunos do ensino fundamental e médio no Brasil e, concomitantemente, o crescimento espantoso do número de organizações nãogovernamentais (ONGs) trabalhando no campo da educação nas últimas décadas, o presente trabalho procura estabelecer uma ponte entre estas duas faces da educação no Brasil. Pretendemos, então, compreender a dinâmica e a influência das ONGs no Brasil no campo da educação e, mais especificamente, no campo da leitura, tendo em vista o desenvolvimento do letramento. Para tanto, fizemos um estudo qualitativo com características etnográficas baseado, sobretudo, em observações feitas em campo das atividades de uma organização e que foram analisadas a partir de concepções de leitura propostas pelos teóricos da psicolingüística (Smith, 1989,1999) e da Estética da Recepção (Jauss, 2002). Com isso, esperamos contribuir com os estudos sobre leitura e, principalmente, avançar nestas novas possibilidades educativas que nos são, hoje, apresentadas pela sociedade civil e que nos direcionam em busca de uma solução alternativa para um problema que vem afligindo os educadores há décadas no Brasil. Nossa principal hipótese seria que a escola pública poderia beneficiar-se e melhorar o grau de letramento de seus alunos, bem como ampliar o número de leitores proficientes/competentes, se pudesse estabelecer uma parceria com as instituições da sociedade civil/ONGs que já possuem um projeto consistente. Assim, por meio de troca de idéias e experiências, as instituições educacionais não-governamentais poderiam contribuir para o desenvolvimento de uma escola pública de qualidade, sem, no entanto, substituí-la de forma alguma, deixando para o Governo a responsabilidade que lhe cabe.

Palavras-chave: Leitura. ONG. Educação não-formal. Letramento. Parcerias. Políticas públicas para educação. Constituição de leitores. 


\begin{abstract}
\end{abstract}
SHITARA-INGLESI, A. Reading activities in Nongovernmental Organizations and Interrelations with the public school: a case study. 2008, 286 f. Dissertation (Master) Faculdade de Educação, Universidade de São Paulo, São Paulo, 2008.

In view of the low level of literacy among students of elementary and middle schools in Brazil and, meanwhile, the astonishing growth of nongovernmental organizations (NGOs) working in the educational field in recent decades, this work tries to establish a connection between those two faces of education in Brazil. We intend to understand the dynamics and influence of NGOs in Brazil, and more specifically, in the field of reading for the development of literacy. Therefore, we did a qualitative study with ethnographic characteristics founded, above all, in remarks made at the field of the activities we saw, which later were examined/analyzed using the reading conceptions proposed by the psycholinguistics scholars (Smith, 1989, 1999) and the Aesthetics of Reception scholars (Jauss, 2002). In this way, we hopefully wish to contribute to the many studies on reading and, in particular, to move forward with these new educational possibilities that are, today, presented by the civil society which is searching for alternative solutions to a problem that has been worrying educators for decades in Brazil. Our main hypothesis would be that public schools could benefit themselves and improve the level of literacy of their students, as well as expand the number of proficient readers / competent, if they could establish a partnership with institutions of civil society / NGOs who already have a consistent project. Thus, by means of an exchange of ideas and experiences, the non-governmental educational institutions could contribute to the development of the quality of our public school, without, however, replace it in any way, leaving what is the governmet responsibility for the government itself.

Keywords: Reading. NGOs. Non-formal Education. Literacy. Partnerships. Policies for public education. Training of readers. 


\section{LISTA DE TABELAS E GRÁFICOS}

Figura 01 - Quadro de doação de empresas a ONGs no Brasil segundo a revista Veja em julho de 2006 $-84$

Figura 02 - Quadro comparativo de tópicos analisados nas 6 ONGs observadas$-147$

Figura 03 - Dados resultantes do questionário inicial aplicado para 219 jovens no $1^{\circ}$ semestre de 2005 - Como você soube dos círculos de leitura? $-162$

Figura 04 - Dados resultantes do questionário inicial aplicado para 123 jovens no $2^{\circ}$ semestre de 2005 - Como você soube dos círculos de leitura? $-163$

Figura 05 - Pontos principais do Projeto "Círculo de Leitura" $-199$

Figura 06 - Passos das atividades realizadas nos "Círculos" 204

Figura 07 - Dados resultantes do questionário inicial aplicado para 219 jovens no $1^{\circ}$ semestre de 2005 - Com que frequiência você lê livros? $-222$

Figura 08 - Dados resultantes do questionário inicial aplicado para 123 jovens no $2^{\circ}$ semestre de 2005 - Com que freqüência você lê livros?

Figura 09 - Dados resultantes do questionário inicial aplicado para 219 jovens no $1^{\circ}$ semestre de 2005 - Alguém lia histórias para você quando era pequeno? 225

Figura 10 - Dados resultantes do questionário inicial aplicado para 219 jovens no $1^{\circ}$ semestre de 2005 - Além de você, quem tem o hábito de ler em casa? $-226$

Figura 11 - Dados resultantes do questionário inicial aplicado para 123 jovens no $2^{\circ}$ semestre de 2005 - Alguém lia histórias para você quando era pequeno? 
Figura 12 - Dados resultantes do questionário inicial aplicado para 123 jovens no $2^{\circ}$ semestre de 2005 - Além de você, quem tem o hábito de ler em casa? --------------------227 
RESUMO --------- 6

ABSTRACT------- 7

LISTA DE TABELAS E GRÁFICOS--- 8

APRESENTAÇÃO ---

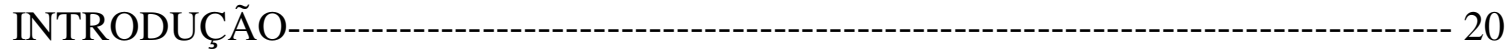

1. METODOLOGIA DE PESQUISA--

1.1 PROBLEMAS E OBJETIVOS--- 29

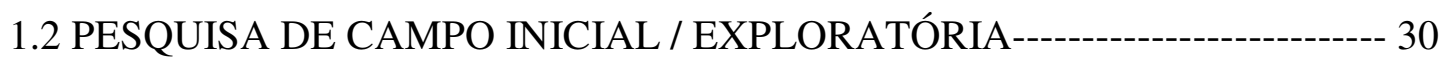

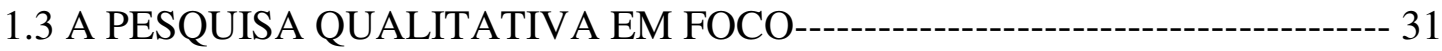

1.3.1 Alguns problemas no uso das abordagens qualitativas

e recursos utilizados para maximizar a confiabilidade dos

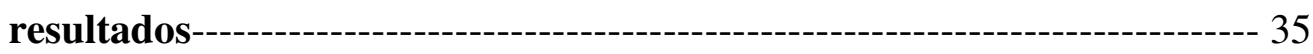

1.4 SUJEITOS DA PESQUISA ---

1.5 TEMPO DE PERMANÊNCIA EM CAMPO-- 38

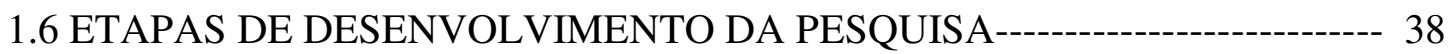

1.6.1 Fase de negociação----------------- 39

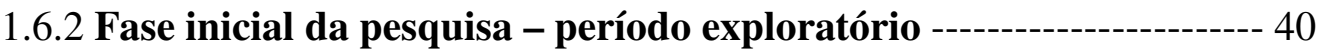

1.6.3 Procedimento para coleta de dados---on 41

1.6.3.1 Observação participante----------------------------- 41

1.6.3.2 Entrevista em profundidade---------------------------- 42

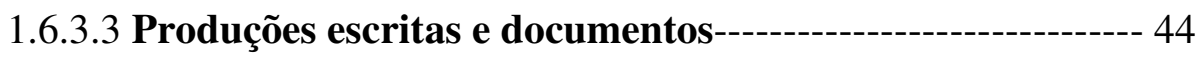

1.6.4 Investigação focalizada: coleta sistemática de dados---------------- 44

1.6.5 Procedimento para análise dos dados - (Análise de

Conteúdo como método de pesquisa)-- 45

1.6.5.1 Triangulação das fontes - observação, materiais escritos e entrevistas---

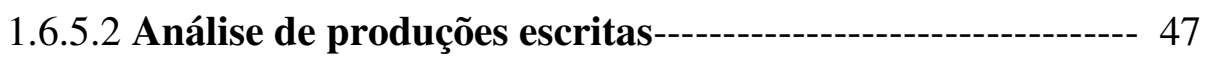




\section{2 . A LEITURA DE TEXTOS LITERÁRIOS}

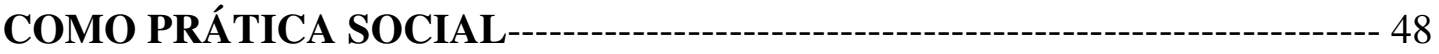

2.1 DELIMITANDO O CAMPO DA LEITURA---------------------------------------- 48

2.2 A LEITURA E SEU PAPEL SOCIAL AO LONGO DA HISTÓRIA:

EM QUE MEDIDA LER É IMPORTANTE?

2.3 PANORAMA HISTÓRICO DA LEITURA NO BRASIL E SEU VALOR NAS

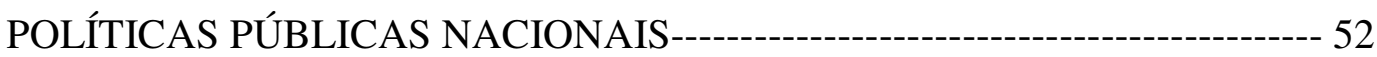

2.4 LENDO LITERATURA E HUMANIZANDO-SE---------------------------------- 54

2.5 PAPEL SOCIAL DA LITERATURA:

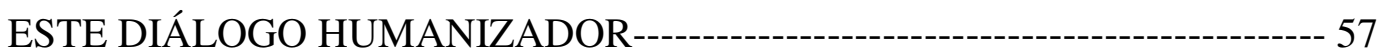

3. DESVELO E LEITURA: A CONSTRUÇÃO SOCIAL DO LEITOR------------ 62

3.1 UM OLHAR SOBRE OS PROCESSOS ENVOLVIDOS

NO ATO DE LER: CONTRIBUIÇÕES DA PSICOLINGÜÍSTICA--------------- 62

3.2 UM OLHAR SOBRE A LEITURA DO TEXTO LITERÁRIO:

CONTRIBUIÇÕES DA ESTÉTICA DA RECEPÇÃO-------------------------- 65

3.2.1 O papel do afeto (prazer emocional) e

do prazer estético-

3.2.2 Construção social do leitor crítico por meio

do prazer estético e emocional: o jovem leitor

e seu horizonte de expectativas

4. AS ONGS NA SOCIEDADE: EM FOCO, A LEITURA

4.1 O PAPEL DAS ONGs NA TRANSFORMAÇÃO DA SOCIEDADE------------ 76

4.2 AS ONGs E A ATUAL SOCIEDADE COMPLEXA------------------------- 78

4.2.1 ONGs - organizações não-governamentais-------------------------- 79

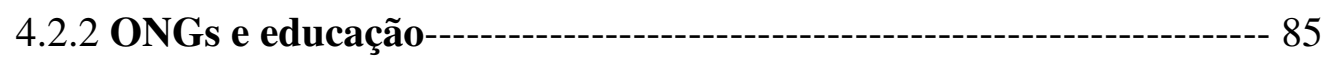

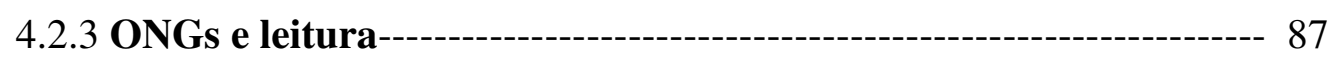

5 . PESQUISA DE CAMPO INICIAL: VISITAS A DIVERSAS ONGs----------- 89 
5.1.1 Histórico, projeto pedagógico e estrutura---------------------------- 90

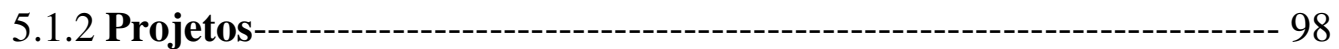

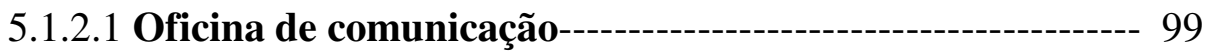

5.1.3 ONG e relação com escola pública ------------------------------- 100

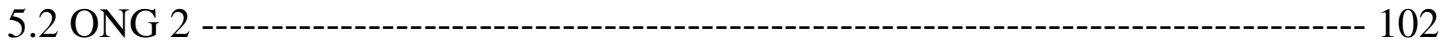

5.2.1 Histórico, projeto pedagógico e estrutura---------------------------- 103

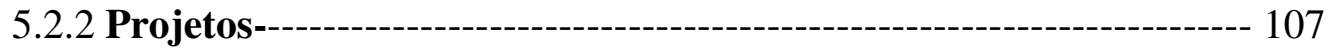

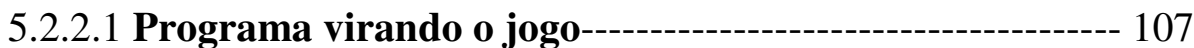

5.2.2.2 Programa de formação de agentes comunitários

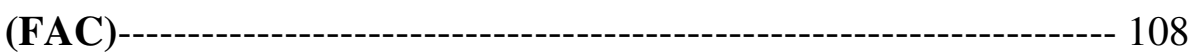

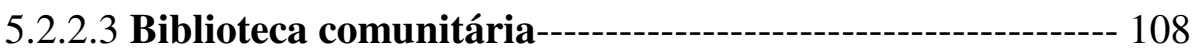

5.2.3 Fundação e escola pública------ 109

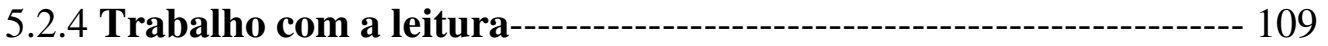

5.3 ONG 3----------------------------------------------------------------------------------------- 111

5.3.1 Histórico, projeto pedagógico e estrutura------------------------ 111

5.3.2 Projetos -Observação de uma atividade--------------------------- 118

5.3.3 ONG, educação comunitária e escola pública----------------------- 123

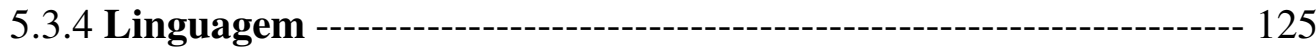

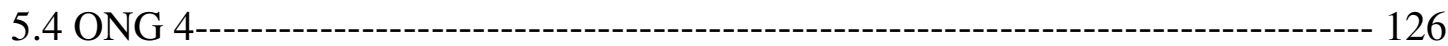

5.4.1 Histórico, projeto pedagógico e estrutura--------------------------- 126

5.4.2 Projetos------------------------------------------------------------------------ 130

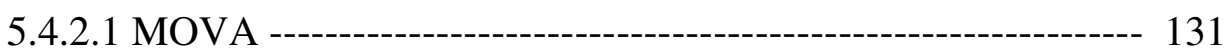

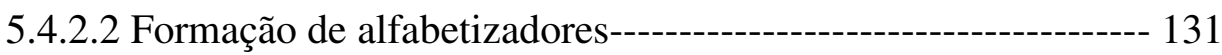

5.4.2.3 Projeto Brasil alfabetizado-------------------------------------- 132

5.4.2.4 Fomento à pesquisa ----------------------------------------------- 132

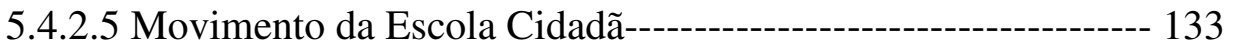

5.4.3 ONG e escola pública----------------------------------------------- 133

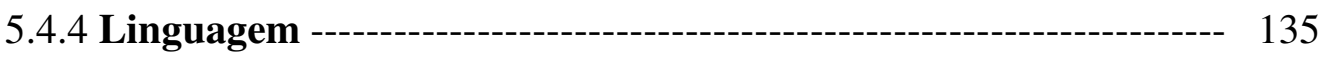

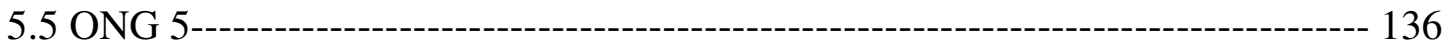


5.5.1 Histórico, projeto pedagógico e estrutura 136

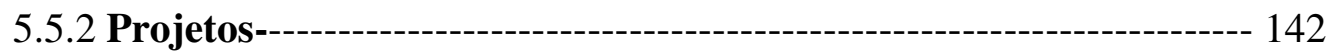

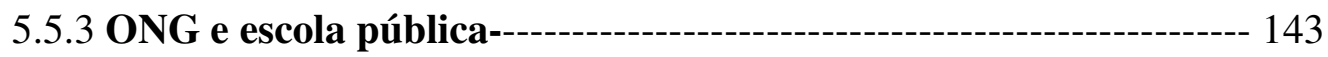

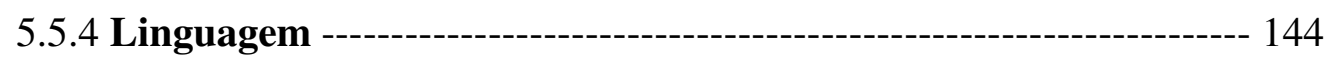

5.6 QUADRO COMPARATIVO DAS ONGs, ANÁLISE DOS DADOS E

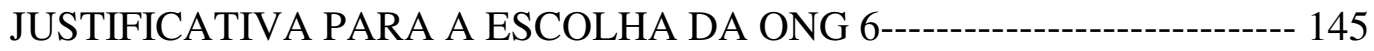

6. ESTUDO DE CAMPO NA ONG 6--- 149

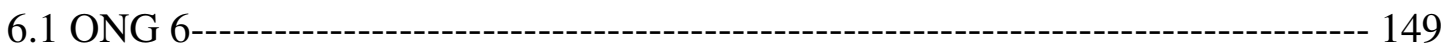

6.1.1 Histórico, projeto pedagógico e estrutura---------------------------- 150

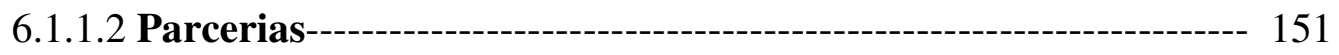

6.1.1.3 Projeto pedagógico/Metodologia------------------------------------ 151

6.1.1.4 Avaliação--------------------------------------------------------------- 153

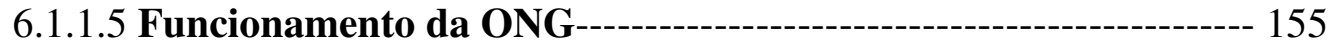

6.1.1.6 Registro de presença e permanência na ONG-------------------- 156

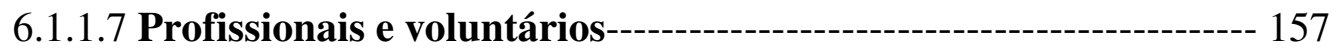

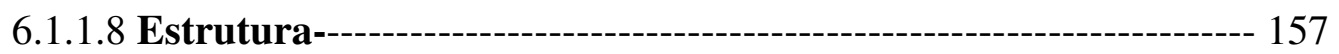

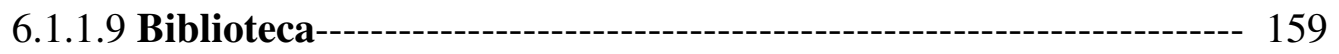

6.2 PROJETO “CÍRCULO DE LEITURA” - ORIGENS ----------------------------- 160

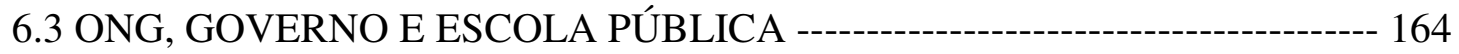

7. ANÁliSE DOS DADOS CONCERNENTES À METODOLOGIA E ÀS INTERAÇÕES DOS PARTICIPANTES DO PROJETO “CÍRCULO DE

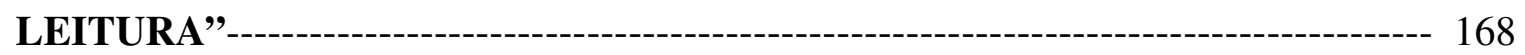

7.1 TEORIA: CONCEPÇÃO DE LEITURA E LEITOR NA ONG----------------- 169

7.1.1 As reflexões da ONG sobre a leitura-------------------------------- 169

7.1.2 Educador Renato e sua concepção

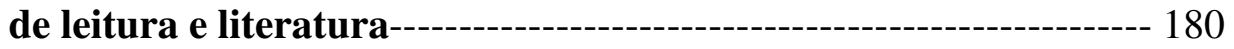

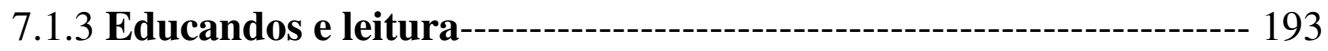

7.2 PRÁTICA: PROPOSTA DE TRABALHO E METODOLOGIA DO

PROJETO "CÍRCULO DE LEITURA" 


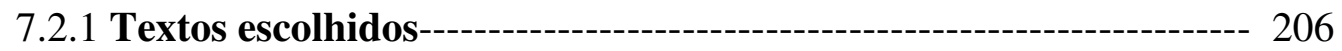

7.2.2 Gestão do tempo e parceria com a escola----------------- 212

7.3 RESULTADO: ANÁLISE DO PROJETO POR PARTE

DOS PARTICIPANTES--------------------------------------------------------------- 213

7.3.1 Os educandos e sua relação com o projeto e com o desenvolvimento da leitura------------------------------------------------------------------------------ 213

7.3.2 Avaliação do projeto pela professora de Português e impacto do

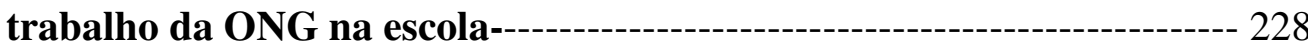

7.3.3 Problemas de evasão, desempenho escolar e outras considerações----

7.3.4 Relacionamentos inter-pessoais:

a questão afetiva e grupal

CONSIDERAÇÕES FINAIS--- 241

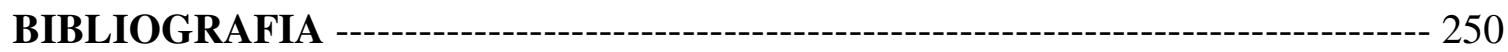

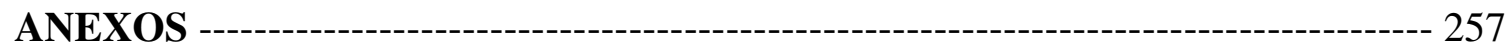

Proposta metodológica dos “Círculos de Leitura”-------------------------------- 257

“Seqüîncia” de João Guimarães Rosa----------------------------------------- 282 



\section{APRESENTAÇÃO}

No Brasil, os problemas concernentes à prática da leitura e ao trabalho com a linguagem sempre foram fatores de preocupação, sobretudo quando sabemos, por princípio, que a leitura é elemento fundamental para que o homem possa exercer a sua cidadania. Constatamos, preocupados, que ainda são poucos os brasileiros inseridos no universo da língua escrita e menos ainda os capazes de ler com espírito crítico o mundo a sua volta.

O domínio da leitura e da escrita é uma das contrapartidas para nossa inserção social porque vivemos em uma sociedade grafocêntrica que deixa à margem aqueles que possuem um pequeno grau de letramento. Ao não lerem, estes indivíduos, segundo Tezzari (2005, p.54), deixam de usufruir os bens culturais produzidos pela sociedade, de exercer seus direitos e não vivenciam práticas sociais significativas, desta forma, sendo excluídos das possibilidades construídas a partir da leitura e escrita.

À parte aqueles que não possuem o domínio da leitura, há ainda uma grande parcela da população que, apesar de ter desenvolvido habilidades de leitura, por motivos diversos, não usufrui dessa aprendizagem. O fato de não realizar leituras com freqüência implica uma redução da habilidade até o ponto de ser considerado analfabeto funcional por alguns teóricos (Azevedo, 1997; Enzensberger, 1985; Tfouni, 1995, 1988).

Desde a época em que cursava o Ensino Fundamental e Médio, percebia entre a maioria de meus colegas, de uma escola particular de São Paulo, a aversão pela leitura e o desinteresse total pelos livros.

Ao começar a ministrar aulas para crianças de classe média alta $^{1}$, constatei a mesma indiferença em relação ao ato de ler. A escola em que trabalhava procurava desenvolver a aquisição de uma língua estrangeira a partir de atividades lúdicas. Sendo assim, realizava diversas atividades das quais as crianças participavam com entusiasmo; porém, quando era

\footnotetext{
${ }^{1}$ Crianças entre $5-12$ anos, cursando a pré-escola e o $1^{\circ}$ ciclo do Ensino Fundamental.
} 
chegada a hora da leitura de um livro em inglês, a maior parte delas mostrava desinteresse e pedia para fazer outra coisa. As palavras "leitura", "livro", "ler" causavam um afastamento quase que instantâneo dessas crianças da atividade, pois esperavam que fosse entediante. Tentando não impor a leitura, procurava outros caminhos, começando a conversar sobre o assunto que o livro trazia, perguntando se já tinham estado naquela situação, se gostavam do assunto (poderia ser "doce", "bichos" etc.) e, assim, a partir de uma conversa informal, introduzia a leitura dizendo: "Pois é, também conheço um menino que gosta de animais, vamos conhecê-lo?". Desta forma se iniciavam as leituras bem sucedidas e, ao final da atividade, percebia que as crianças haviam se divertido, prestado atenção e aprendido alguma coisa. Comecei então a indagar-me sobre o porquê desse bloqueio inicial que grande parte de meus alunos apresentava diante das atividades de leitura. Ao longo da minha trajetória, tem sido, portanto, muito comum encontrar crianças e adultos de diferentes classes sociais que acham ler uma atividade sem atrativos, demorada, obrigatória e cansativa.

Ao realizar estágios em escolas públicas de São Paulo (tanto escolas estaduais como municipais da Zona Sul de São Paulo) durante o período em que cursei a Licenciatura na Faculdade de Educação, estive sempre atenta aos hábitos de leitura dos alunos, indagando-os sobre suas preferências e contato com a matéria escrita. Na grande maioria das vezes, deparei-me com crianças sem interesse pelos livros, com pouco contato com o material impresso e com baixa freqüiência de leitura, tal como aquelas da escola particular em que havia estudado.

À medida que o estágio decorria, foi ficando claro que as professoras também não estimulavam seus alunos a ler, e mais claro ainda que, com seus exercícios estruturais / gramaticais e cópias sem fim, elas afastavam cada vez mais os alunos do universo da leitura e da língua portuguesa.

Sendo responsabilidade da escola e dos professores formar leitores (principalmente quando atendem alunos que não possuem contato com diversidade de materiais escritos, relações com a leitura e nem com leitores na família), esperava que as professoras investissem na constituição de leitores orientando os alunos e sugerindo-lhes leituras, mas nada disso ocorria em sala de aula, elas não liam para seus alunos, não contavam histórias e nem sequer disponibilizavam o acervo. 
As bibliotecas escolares, quando existiam, permaneciam fechadas: os alunos só podiam visitá-las em companhia das professoras (que raramente o faziam) e a retirada de livros era proibida, devido à ausência de um bibliotecário responsável.

Neste quadro, a leitura sempre me pareceu ocupar um espaço periférico na sala de aula, só acontecendo para preencher um espaço de fim de aula e ancorada sempre em textos do livro didático. O objeto 'livro', o objeto 'jornal' e o objeto 'revista' eram inexistentes. De modo geral, as aulas reduziam o ato de ler a um simples processo de decodificação e ao uso de textos como pretextos para o ensino de gramática, ou ainda, observava o texto literário sendo trabalhado como texto informativo, com atividades que demandavam a simples retirada de informações, sem qualquer trabalho voltado à fruição estética/artística.

Ainda na graduação, considerando estas primeiras observações, passei a interessar-me cada vez mais pela questão da leitura, bem como pela linguagem e procurei a professora Dra. Idméa Semeghini-Siqueira para tornar-me sua orientanda de iniciação científica. Procurava, com isso, aprofundar-me nestas questões e buscar entender porque tantos alunos não percebiam a riqueza da leitura dos livros como atividade cultural complexa, de muitos aspectos (sociológico, histórico, psicológico etc.) e, porque não, prazerosa.

A princípio, a idéia era buscar saber quais os fatores determinantes e como, na trajetória de sua vida particular e escolar, uma pessoa tornava-se um leitor fluente e assíduo. No entanto, ao iniciar a pesquisa sobre este tema, encontrei uma tese de doutorado no Instituto de Psicologia da Universidade de São Paulo que o havia trabalhado com certa profundidade (Marques, 1999). Vendo o meu projeto inicial de pesquisa já realizado, parti em busca de um novo tema, por entender que o assunto, visto por esta perspectiva, não precisaria ser ainda mais aprofundado.

A despeito disso, instigou-me o sintomático aumento do voluntariado e a disseminação pelo país das Organizações não-governamentais (ONGs) nos últimos anos. Já chamava a minha atenção a importância da ação civil nos problemas concernentes a todos nós, como: saúde, educação, meio ambiente, políticas públicas, arte e cultura etc. Assim, 
tornei-me voluntária em uma creche no bairro da Liberdade, onde entrei em contato pela primeira vez com a população mais carente da cidade de São Paulo. Posteriormente, trabalhei em uma Oficina de linguagem no âmbito do projeto Esporte-Talento do Instituto Ayrton Senna em parceria com o CEPEUSP (Centro de Práticas Esportivas da Universidade de São Paulo), como parte de meu estágio para a disciplina de Metodologia do Ensino de Língua Portuguesa (MELP) do curso de Licenciatura. Nesse projeto, a professora Idméa SemeghiniSiqueira havia ministrado um curso para a formação de educadores e abriu espaço para os estagiários realizarem oficinas de linguagem.

Estes primeiros contatos, aliados à minha experiência prévia como professora de crianças, começaram a gerar a primeira idéia para este projeto: o trabalho com a linguagem e, em particular, com a leitura, realizado pelas ONGs com jovens e crianças. Participei então, como observadora, das mesas-redondas sobre movimentos sociais, ONGs e educação no "Fórum Mundial de Educação - São Paulo" e de diversos seminários como forma de inteirarme melhor sobre o assunto e começar a estudá-lo.

Em uma das escolas estaduais onde havia estagiado (desta vez, um estágio de observação em sala de aula para a mesma disciplina), observei alguns alunos que vestiam a camiseta de uma ONG que existia nas proximidades. Ao conversar com estes alunos, percebi o quanto eles gostavam de participar deste projeto social e o quanto eles não gostavam de vir para a escola. Suas falas eram recheadas de comparações.

Nesta ONG, os alunos precisavam cumprir certas obrigações / tarefas e não podiam faltar às atividades que abrangiam aulas de inglês, francês, informática, capoeira, artes, aulas de reforço, entre outras. Assim, esta ONG trabalhava como um espaço educativo diferente: aquele que os alunos adoravam. Eles relatavam que ficavam anos na fila da instituição para conseguir uma vaga e, quando a conseguiam, nunca faltavam às aulas e atividades que aconteciam todos os dias da semana, antes da escola e aos sábados das $7 \mathrm{~h} 30$ às $12 \mathrm{hs}$.

A partir de então, uma série de questionamentos foi surgindo destas experiências: por que será que estes dois espaços de aprendizagem, a escola e a ONG, eram tão diferentes para os educandos? Exatamente em que aspectos suas metodologias se diferenciavam? Por que em uma as crianças aprendiam e se divertiam e na outra nem tanto? E, principalmente, as ONGs podem ajudar a escola pública a melhorar? 
Levantei a hipótese de que as ações civis na área de educação poderiam contribuir, junto com a escola, e nunca em substituição à mesma, para a constituição de leitores. Essa perspectiva explicativa surgiu-me pela articulação entre as duas experiências anteriormente relatadas, tendo me apoiado na constatação de Macedo e Semeghini-Siqueira (2000, p. 5) de que,

há algumas décadas, a escola era considerada a única instância para a educação do cidadão, mas que atualmente, entretanto, é preciso redimencionar este quadro, incluindo a biblioteca, a mídia (televisão, rádio, cinema, teatro, jornal etc.), a nova mídia (a Internet) e, obviamente, a família e a comunidade, em especial, as ONGs.

Focalizando a importância da parceria entre a educação formal, fornecida pela escola, e a educação não-formal, feita fora da instituição escolar (no caso desta pesquisa, aquela realizada pelas ONGs), pretendo trazer para a discussão o papel fundamental que possui a sociedade como um todo na constituição de leitores, a partir do momento em que consideramos a leitura como atividade cultural e, portanto, de caráter social, não podendo, assim, esperar que a promoção da leitura seja de responsabilidade exclusiva das instituições escolares. 


\section{INTRODUÇÃO}

Um dado que alarmou os educadores em 2000 e em 2003 foi o resultado do Programa Internacional de Avaliação de Alunos, o PISA, coordenado pela Organização para a Cooperação e o Desenvolvimento Econômico (OCDE). Em 2000, na prova de leitura, o Brasil ficou com uma média de 396, numa escala de zero a 800, ficando em último lugar entre os 31 países participantes. Com o ingresso de mais dez nações (PISA ampliado), o país acabou ficando em $37^{\circ}$ lugar entre 41 países, à frente somente da Macedônia, da Indonésia, da Albânia e do Peru. Na média geral (incluindo conhecimentos de matemática e ciências), o Brasil ficou em penúltimo lugar. Em 2003, nosso resultado continuou bem abaixo da média, ficamos em $32^{\circ}$ lugar dentre os 41 países participantes.

Apesar dos inúmeros questionamentos metodológicos que podem ou não surgir a partir deste dado e dos interesses a ele subjacentes ${ }^{2}$, o consideramos importante na medida em que nos serve como um indicador da leitura no nosso país, e explicita, quer gostemos ou não, uma situação já evidente: há muito tempo, o Brasil apresenta dificuldade em constituir leitores.

Durante muitos anos buscamos traçar respostas e justificar a importância da superação da crise da leitura em nosso país. Dentre as mais diversas correntes teóricas existentes, uma afirmação nos parece consensual: que o exercício da cidadania passa pela capacidade de ler criticamente o mundo e de poder participar ativamente de todas as práticas sociais que envolvem a língua escrita, principalmente, devido ao fato de estarmos inseridos em uma sociedade grafocêntrica.

Sendo a leitura uma prática social, refletimos sobre sua importância, na medida em que brasileiros que possuem um grau mínimo de letramento deixam de usufruir efetivamente dos bens culturais produzidos pela sociedade e se vêem impedidos de exercerem direitos e deveres de qualquer cidadão.

\footnotetext{
${ }^{2}$ Para uma análise mais aprofundada sobre o instrumento de avaliação de leitura do Pisa 2000, ver Capítulo 4 do seguinte trabalho: Marchetti, G.N. (2005). Leitura e leitor: análise do dizer teórico e do fazer prático em uma proposta avaliativa. São Paulo, Dissertação de Mestrado, Faculdade de Educação da USP.
} 
Tendo em vista esta observação, torna-se evidente a necessidade de se buscar a melhoria da qualidade de ensino e a elevação do grau de letramento dos alunos brasileiros, permitindo que estes desenvolvam habilidades essenciais para a participação efetiva na sociedade.

Naturalmente, a gravidade do problema do ensino e aprendizagem da leitura no Brasil deu origem a um número significativo de pesquisas em diversas universidades, como na Universidade de S.Paulo, na Pontifícia Universidade Católica de S. Paulo e na Universidade de Campinas, que buscam discutir os entraves e obstáculos existentes para que finalmente possamos construir um país de leitores.

Dentre essas pesquisas, parecem existir dois grandes estilos de investigação relacionados ao campo da leitura. Uma parte desses estudos traça um diagnóstico do que ocorre no ensino da leitura no âmbito escolar e, às vezes, no nível universitário, buscando apontar, eventualmente, saídas para os problemas observados. São saídas que, em alguns casos, nem sempre foram postas em prática e que podemos considerar como especulações. Um segundo tipo de investigação engloba aquelas que problematizam as teorias relacionadas à leitura, atendo-se principalmente à análise de diferentes práticas.

Há, em ambas as linhas de pesquisa, aquelas que, ao invés de simplesmente especular, buscam mostrar algumas respostas para o problema e o que está efetivamente sendo feito para melhorar a leitura de nossos alunos. A maior parte desses trabalhos tem origem em estudos de casos e ações pontuais que ocorrem em uma determinada escola e que poderá vir a servir como exemplo de uma prática pedagógica efetiva de leitura.

A imensa maioria desses estudos acadêmicos apresenta aprofundamento e grande consistência na análise dos entraves e dificuldades pelas quais passam alunos e professores no decorrer dos processos de ensino e aprendizazem da leitura nas escolas. Freqüentemente, problematizam questões teóricas e pré-conceitos existentes na sociedade, comparam nosso sistema escolar com sistemas de ensino de outros países, analisam e observam/descrevem situações complexas que vão além dos muros da escola, tendo suas raízes, muitas vezes, em razões sociais e /ou pessoais, como por exemplo, a influência familiar na constituição do leitor. 
Tais estudos foram elaborados tendo a escola como foco principal de suas ações e análises teóricas, o que é bastante compreensível visto que, na área educacional, a escola é a principal instituição e agente dos processos de ensino e aprendizagem. Porém, os estudiosos da leitura no meio acadêmico acabaram deixando de lado um fato relativamente novo, mas cada vez mais importante na sociedade atual: o surgimento do vasto campo da educação nãoformal promovida pelas inúmeras ONGs (organizações não-governamentais) existentes no Brasil, que tem crescido com velocidade e intensidade excepcionais.

Comparados com os estudos relacionados à leitura, são escassos os trabalhos que tratam das Organizações Não-Governamentais (ONGs) e dos movimentos sociais ligados à educação. É nulo o número de estudos sobre práticas de leitura nestes espaços, segundo levantamento de dados provenientes de teses e dissertações das três universidades citadas anteriormente. Assim, parece-nos necessário um estudo que focalize a questão da leitura nesse novo caminho educativo que hoje possui grande influência no campo educacional e nas tomadas de decisões relativas às políticas públicas para a educação.

O presente trabalho, portanto, pretende ser uma contribuição para começar a suprir esta lacuna e responder à demanda de estudos que buscam compreender a dinâmica e a influência das ONGs no Brasil tanto no campo da educação, como, mais especificamente, no campo da leitura e, portanto, do desenvolvimento do letramento.

Foi a partir dos anos 90 que a sociedade civil começou a atuar mais intensamente no Brasil, buscando soluções para problemas educacionais que, infelizmente, o ensino público não tem conseguido resolver sozinho. As propostas vindas das inúmeras ONGs, apesar de ainda serem pouco difundidas e estudadas no meio acadêmico, talvez possam trazer resultados positivos, estimulando o prazer de ler e aumentando o grau de letramento entre a população de baixa renda, em geral, a que possui menos acesso aos bens culturais produzidos pela sociedade.

Assim, tendo em vista a problemática que nossas escolas vêm enfrentando no tocante à constituição de leitores, formulamos a seguinte pergunta: a sociedade, por meio dos movimentos sociais e organizações não-governamentais, pode efetivamente ajudar a melhorar este quadro? E, se é possível, como e em que medida? 
Nesse sentido, o trabalho de desenvolvimento da leitura para ampliação do grau de letramento realizado pela sociedade civil será o objeto de estudo desta pesquisa, uma vez que, talvez, possa nos indicar uma saída para um problema que vem afligindo os educadores há décadas no Brasil.

Ao justificarmos a escolha deste tema, partirmos do pressuposto de que a leitura, inicialmente, não é um ato solitário. Assim, não se lê sem que haja diálogo e não nos constituímos como leitores sem o contato com o outro. Ao mobilizar todo o repertório daquele que lê, suas crenças e valores, ou seja, sua relação com o mundo e com as pessoas que o circundam, podemos pensar na leitura como produção social e socializadora ao mesmo tempo. De acordo com Eireter (2001, p. 25), o modo como interpretamos o mundo, os estímulos que dele recebemos (sejam imediatos ou mediados por textos), a leitura que dele realizamos, é socialmente construída e muda ao longo da história.

No livro "Questões de literatura e estética", ao discutir a questão do discurso na literatura, Bakthin (1988, p. 86) nos revela que o diálogo inerente aos diversos discursos fazse, sobretudo, dentro de uma esfera social:

O enunciado existente, surgindo de maneira significativa num determinado momento social e histórico, não pode deixar de tocar os milhares de fios dialógicos existentes, tecidos pela consciência ideológica em torno de um dado objeto de enunciação, não pode deixar de ser participante ativo do diálogo social. Ele também surge desse diálogo como seu prolongamento, como sua réplica (...)

Sendo "todas as palavras e formas que povoam uma linguagem vozes sociais" (p.106), Bakhtin (1988, p. 100) conclui que

Em essência, para a consciência individual, a linguagem enquanto concreção sócio-ideológica viva e enquanto opinião plurilíngüe, coloca-se nos limites de seu território e nos limites do território de outrem.

Tendo este caráter notadamente social e sendo ao mesmo tempo uma atividade cultural, conclui-se que a constituição de leitores deve ser uma preocupação para a sociedade como um todo e, sendo assim, não se pode esperar que a promoção da leitura seja uma tarefa a cargo somente da escola ou da família. Eireter (2001, p. 13) ainda complementa que é justamente em países onde não existe uma tradição de leitura que o esforço para que ela se constitua deve permear toda a sociedade e não apenas alguns setores da mesma. 
Pensamos, então, que a leitura, tanto de textos informativos quanto de textos literários, faz parte do mundo escolar, mas que não deve, de maneira nenhuma, a ele se restringir. É importante que a leitura faça parte do cotidiano, da vida fora dos bancos escolares e esteja presente, repleta de significação, em todos os momentos, nas interações do sujeito com o mundo, ou seja, na sua experiência social.

Na medida em que a sociedade torna-se mais complexa, portanto, a forma e a função tradicionais da educação se tornam insuficientes, e passamos a questionar, não a prioridade da escola, mas sua centralidade como lócus de saber a ser disseminado e sistematizado.

Vale ressaltar que, segundo Brunstein (2003, p. 43),

a idéia de que os interesses coletivos não podem ser cuidados exclusivamente pelo poder público central - muitas vezes distantes dos problemas locais, específicos e multifacetados - dá vazão a uma série de ações organizadas pela sociedade civil.

Segundo a mesma autora (2003, p. 100), dentre os programas inscritos de ONGs no Prêmio Itaú-Unicef de 1999, 93\% disseram atuar na área de educação - o que torna ainda mais evidente a importância de estudos referentes a projetos dos movimentos civis que trabalham com a educação, uma vez

O Prêmio Itaú-Unicef foi criado pela Fundação Itaú Social e pelo Fundo das Nações Unidas para a Infância (UNICEF) para reconhecer e estimular o trabalho de organizações que contribuam para a educação integral de crianças e adolescentes brasileiros de 6 a 18 anos em condições de vulnerabilidade socioeconômica, estimulando seu ingresso, regresso, permanência, aprendizagem e participação na escola.

que são muitos. Logo, torna-se necessário, em vista deste dado, sabermos o que estes projetos estão fazendo e como eles podem auxiliar na melhoria da educação nacional e do grau de letramento, se é que eles podem contribuir para essa melhoria.

Mais adiante, o presente trabalho pretende discutir não somente a questão da leitura, mas, também, a problemática das próprias ONGs na sua relação com o Estado, na medida em que não devem assumir para si as responsabilidades que cabem ao governo, nem funcionar como meio assistencialista que não atinge objetivos a longo prazo, como ajudar a desenvolver o grau de letramento de nossos alunos. Essas questões e outras problemáticas a elas relacionadas serão analisadas com maior aprofundamento no capítulo 4 do presente trabalho. 
Nossa hipótese geral é que, por meio desta nova proposta de educação não-formal (ou seja, fora do sistema escolar), possamos despertar o interesse pela leitura e, conseqüentemente, ampliar o grau de letramento de crianças e jovens. Especificamente, partimos da hipótese de que a escola pública poderia também se beneficiar no sentido de melhorar o grau de letramento de seus alunos, ampliando o número de leitores proficientes/competentes, se pudesse estabelecer uma parceria com as instituições da sociedade civil/ONGs portadoras de um projeto consistente e que apresentem bons resultados. Assim, por meio de uma troca de idéias e experiências, as ONGs e instituições educacionais não-governamentais poderiam ajudar no desenvolvimento de uma escola pública de qualidade, sem substituí-la de forma alguma, deixando ao Estado a responsabilidade que lhe cabe.

Ainda no âmbito de nossas hipóteses, acreditamos que, talvez, o que favoreça o sucesso dos laboratórios pedagógicos de leitura nestas diversas organizações seja a vantagem que algumas ONGs possuem em relação à maior parte das escolas, por não se sentirem obrigadas a cumprirem um currículo pré-determinado e não sofrerem as inúmeras pressões e cobranças que sofrem os professores por parte de alunos, pais, diretoria e do próprio tempo. Além disso, ainda contam, como participantes de suas atividades, com alunos que estão lá espontaneamente e que talvez por isso acabem participando das atividades com mais interesse e entusiasmo, diminuindo consideravelmente, desta forma, a incidência de indisciplina.

Assim, fora do ambiente da escola, e longe das obrigações e pressões curriculares e burocráticas tão freqüentes neste ambiente, tanto os alunos como os professores sentir-se-iam mais à vontade para utilizarem novas metodologias. Tais metodologias inovadoras e, na nossa hipótese, eficazes, que estão em curso nestes espaços não-escolares, podem contribuir para um redirecionamento das práticas metodológicas utilizadas nas escolas públicas. Não pretendemos com isso afirmar que todas as escolas públicas sofram pressões curriculares e não estejam abertas para novas práticas; porém, por meio de diversas pesquisas podemos verificar que a grande maioria de nossas escolas enfrenta sérios problemas quando o assunto se refere a novas práticas educativas.

Cabe aqui ressaltarmos que apesar de a LDB e os PCNs representarem "um passo à frente para o ensino de Língua Portuguesa, pois suas propostas estão estabelecidas sobre 
pilares teóricos sólidos" (Polido, 2003, p. 112), e de darem autonomia aos professores em relação a diferentes práticas educativas, servindo como "rumos para os quais a educação deve caminhar" (NASCIMENTO e GREGORIN, 2000, p. 11) e como "texto de apoio ao professor à reflexão sobre à prática educativa e na análise do material didático" (POLIDO, 2003, p. 6), em geral, percebe-se que o cotidiano escolar, a distância existente entre estes documentos e os professores, bem como a força da tradição acabam sendo obstáculos para a implementação de novas práticas.

De acordo com Polido (2003), tanto os PCNs quanto a LDB, para serem compreendidos, requerem conhecimentos e leituras prévias que boa parte dos professores não teve oportunidade de incluir em seu repertório. A autora nos mostra que os PCN-LP (de língua portuguesa) não atingem seus objetivos, pois há uma "leitura ineficiente das propostas pela maioria dos professores" (2003, p. 10), vinculada a uma intimidação e frustração dos professores frente ao documento: "o diálogo entre texto (PCN) e leitor (professores), neste caso, tende a ser lacônico, com poucas interações e, muito provavelmente, raros resultados práticos" (p.113).

Assim, as dificuldades no uso da língua, a falta de corpus de referência e as implicações da formação inicial e continuada dos professores interferem diretamente na compreensão e no uso dos PCNs pelos mesmos (p. 10). Polido (2003, p. 117) conclui que:

(...) não bastam políticas públicas que apresentem propostas inovadoras e consistentes, para que sejam perceptíveis os reflexos na prática pedagógica. Também não é razoável que a pena pela não concretização de uma proposta pertinente seja imputada unicamente aos professores, identificando-os como ineficientes e desmotivados. Retomando Perrenoud [1993], a transformação das práticas pedagógicas passa não apenas pela disponibilização de novas teorias, mas também pela transformação do habitus. Daí julgamos imprescindível entender a formação do professor como um processo para o qual contribuem experiências extra e intra-escolares, e saberes que transitam tanto pelo campo teórico como pelo campo prático.

Segundo Semeghini-Siqueira (2006, p. 10), no cotidiano “da sala de aula 'incide' uma intrincada teia, tecida por tênues fios, na qual se entrecruzam questões de formação inicial / contínua e condições de atuação do professor na escola de um país em desenvolvimento". 
A autora afirma que, desde a década de 50, as aulas de Língua Portuguesa têm, na sua maioria, focalizado práticas antigas de ensino gramatical, desconsiderando o trabalho com práticas novas de oralidade-leitura-escrita. Em suas investigações, ela conclui que há duas forças que incidem sobre o professor no dia-a-dia da sala de aula que são obstáculos para a implementação de novas práticas educativas (p. 11), sendo a primeira delas o poder do passado, “o 'círculo vicioso' em que se reproduzem as 'formações imaginárias' dos universitários (professores em formação) acerca das práticas de seus antigos professores, portanto, das representações que armazenam em sua 'memória discursiva"” (p.10):

- uma força que provém de hábitos introjetados, ou seja, da rede de interconexões existentes no conjunto mente-cérebro do professor, constituída por vivências e conhecimentos de um longo período de 11 anos no ensino básico, que propicia um rápido acionamento de práticas muito repetidas / bem conhecidas / seguras de seus antigos professores.

- outra força, relacionada ao contexto adverso, às condições de atuação dos professores, que resulta da pressão das "práticas tradicionais" instaladas na escola atual por uma série de motivos: o número excessivo de alunos nas salas de aula; problemas de indisciplina e violência na sala de aula ou ausência de motivação dos alunos; a problemática das Bibliotecas Escolares ou Salas de Leitura (o acervo insuficiente/inadequado, a ausência de um profissional para realizar uma mediação eficiente e a falta de estrutura para livre acesso ou até inexistência de um espaço destinado à biblioteca em muitas escolas); os empecilhos para um uso sistemático do Laboratório de Informática; a falta de jogos/materiais pedagógicos diversificados na sala ambiente, além de livros didáticos; o grau reduzido de compromisso com a educação dos dirigentes de algumas escolas; as condições precárias para a educação contínua dos professores; o tempo "insuficiente" para o planejamento das aulas; os aviltantes salários dos professores; enfim, um conjunto de critérios que os responsáveis pelas políticas públicas têm estabelecido para a educação no Brasil.

Tendo em vista todas estas condições adversas que enfrentam os professores no ensino público, acreditamos que as ONGs podem auxiliar os professores, aos poucos, a inserir novas práticas educativas de leitura nas escolas. Assim, para que possamos averiguar se estas hipóteses se confirmam e responder a nossa pergunta de pesquisa, pretendemos, no presente trabalho, analisar e explicitar primeiramente os fundamentos teóricos, ou seja, a concepção de leitura que subsidia as propostas que estão sendo trabalhadas por instituições não-escolares da sociedade civil. Em seguida, realizamos a descrição e análise de nosso estudo de campo propriamente dito. 
Para tanto, nossa pesquisa está organizada em 7 capítulos. No primeiro capítulo, esclarecemos a metodologia utilizada, discutindo a contribuição das pesquisas etnográficas no campo educacional, bem como explicitamos quem são os sujeitos participantes e os instrumentos utilizados para a coleta de dados. Nos capítulos 2 e 3, problematizamos conceitos que visam a esclarecer os aspectos nodais desta pesquisa e seu papel social, levando em consideração a função do prazer emocional e estético na constituição do leitor e a influência da Estética da Recepção nos estudos sobre a leitura. Em seguida, no capítulo 4, buscamos traçar um breve histórico das organizações não-governamentais, sua atuação na área da educação no Brasil e discutir o que entendemos por educação formal, educação nãoformal e ONG, refletindo sobre este tema tão controverso. No capítulo 5, são apreciadas as propostas educacionais e descritas as estruturas de diferentes instituições não-governamentais visitadas no decorrer de uma pesquisa de campo exploratória. A seguir, nos capítulos 6 e 7, a partir de intensa pesquisa de campo, acompanhamos o trabalho de uma organização para averiguar sua eficácia ou não, bem como seu relacionamento com a escola pública, buscando com isso explicitar e analisar as novas metodologias propostas por este espaço educativo. Finalmente, pretendemos estabelecer relações entre os tópicos: grau de letramento / leitura / escola pública / organizações da sociedade civil, de modo a compreender como as ações podem e devem ser coerentemente articuladas para obter sucesso na constituição de novos leitores. Procuramos avaliar, também, a parceria entre escola pública e organizações da sociedade civil com o intuito de buscar uma solução para o problema da leitura no Brasil.

Entendemos que, ao identificarmos as novas metodologias e saídas propostas pela sociedade civil, podemos contribuir para abrir perspectivas de solução, tornando a leitura significativa para crianças e jovens de um país em desenvolvimento. E, assim, talvez possamos avançar nestas novas possibilidades educativas que são, hoje, propostas pelas ONGs e pelos movimentos da sociedade civil nesta área.

Julgamos que a leitura, considerada na sua dimensão social, no presente trabalho, e o quadro geral que pretendemos traçar das ONGs educativas, tornam o tema relevante para professores, diretores e coordenadores pedagógicos que, eventualmente, entrem em contato com novas práticas educacionais, mas também para todos os profissionais que trabalham no campo da educação e que talvez encontrem neste trabalho mais uma contribuição para o estudo das práticas educativas nesta área. 


\section{CAPÍTULO 1 - METODOLOGIA E SUJEITOS DE PESQUISA}

Neste capítulo, a partir dos problemas e objetivos desta dissertação, definimos as características desta pesquisa de cunho etnográfico, mostrando suas vantagens e desvantagens. Mais adiante, expomos as etapas de desenvolvimento do estudo, o tempo de permanência no campo e apresentamos os sujeitos analisados. São detalhados também os procedimentos de coleta (observação participante, entrevistas, produções escritas e documentos) e de análise de dados (triangulação de dados).

\subsection{PROBLEMAS E OBJETIVOS}

Nesta investigação, procuramos responder à pergunta central deste trabalho, a saber: no tocante à constituição de leitores, a sociedade, por meio das organizações nãogovernamentais, pode efetivamente ajudar a melhorar o grau de letramento dos jovens brasileiros? Como e em que medida? A fim de responder a esta questão e atingir os objetivos mais adiante listados, escolhemos realizar uma pesquisa de cunho etnográfico que busca retratar o contexto de forma mais complexa e profunda, revelando a multiplicidade de dimensões presentes em uma determinada situação, focalizando-a como um todo, e, assim, permitindo uma análise mais acurada dos eventos presenciados.

São analisados e explicitados os fundamentos teóricos e as atividades realizadas, ou seja, a concepção de leitura que subsidia as propostas que estão sendo trabalhadas por instituições não-escolares da sociedade civil. Para tanto, temos os seguintes objetivos:

- $\quad$ Explicitar conceitos que visem a esclarecer aspectos nodais desta pesquisa como: letramento, leitura, literatura, educação formal, educação nãoformal e ONG;

- $\quad$ Expor um breve histórico das ONGs na área da educação;

- $\quad$ Fazer o levantamento de propostas educacionais de diferentes instituições não-governamentais relacionadas ao problema da leitura; 
- $\quad$ Acompanhar o trabalho de uma organização e averiguar sua eficácia ou não, e o seu relacionamento com a escola pública. Explicitar e analisar as novas metodologias propostas por este novo espaço educativo;

- Analisar e procurar capturar o ponto de vista dos participantes do projeto investigado no tocante à leitura e ao leitor;

- $\quad$ Estabelecer relações entre os tópicos: grau de letramento / leitura / literatura / escola pública / organizações da sociedade civil, de modo a compreender como as ações podem e devem ser coerentemente articuladas para obter sucesso na constituição de novos leitores;

- $\quad$ Avaliar a parceria entre escola pública e organizações da sociedade civil com o intuito de buscar uma solução para o problema da leitura no Brasil.

Assim, ao atingir esses objetivos, esperamos identificar novas metodologias colocadas como saídas propostas pela sociedade civil, no sentido de abrir perspectivas de solução para tornar a leitura significativa para crianças e jovens de um país em desenvolvimento.

\subsection{PESQUISA DE CAMPO INICIAL / EXPLORATÓRIA}

Este primeiro período refere-se a aproximadamente quatro meses, durante os quais, munidos de referências (notícias veiculadas em mídia de grande circulação, experiências pessoais), pesquisas na ABONG - Associação Brasileira de Organizações NãoGovernamentais - e por meio de prêmios e selos de reconhecimento, travamos contato com diferentes ONGs, com o intuito de conhecer diversas organizações que possuíam a educação como foco principal de suas ações.

Foram realizadas diversas visitas a oito ONGs, até encontrar um projeto em que esta pesquisa pudesse ser realizada, em uma organização aberta e disposta a facilitar a nossa inserção em campo.

A descrição dessas visitas e as observações feitas durante este período encontram-se no capítulo 5 desta dissertação. Enfatizamos que estas descrições não constituem o corpus do estudo de caso, servindo, no entanto, para fornecer um panorama geral dos trabalhos realizados por diferentes ONGs na cidade de São Paulo. 


\subsection{A PESQUISA QUALITATIVA EM FOCO}

Para realizar este trabalho, fizemos uma pesquisa qualitativa que buscou estudar as atividades promovidas pela ONG 6 (sediada no município de São Paulo, mas com atuação nas escolas públicas do $\mathrm{ABC}^{3}$ ), direcionadas para a melhoria e para o estímulo à leitura - o que constitui o corpus desta dissertação. Desta forma, estabelecemos relações entre as ações da ONG em questão e o auxílio efetivo ou não à constituição de novos leitores.

Segundo Ludke e André (1986, p. 3 e 4), a pesquisa qualitativa surgiu para suprir as carências deixadas por outros métodos de pesquisa, como as análises quantitativas multivariadas que procuravam decompor os fenômenos educativos em variáveis básicas, e freqüentemente transformavam o contexto complexo que observavam em um esquema simplificador.

Até o fortalecimento das pesquisas qualitativas, a tradição em metodologia de pesquisa defendia também a neutralidade do pesquisador, que é contestada pelas autoras acima citadas, quando afirmam ser impossível estabelecer uma separação nítida e asséptica entre o pesquisador e seu objeto de estudo, uma vez que aquele traz consigo todo o seu conhecimento sobre o assunto (uma dada teoria) bem como sua visão política. Gómez, Flores e Jiménez (1999, p. 32) ainda completam que "la investigación cualitativa no puede contemplarse por más tiempo desde una perspectiva positivista, neutral y objetiva".

A definição de pesquisa qualitativa pode diferir, em pequenos aspectos, de estudioso para estudioso, porém, segundo Gómez, Flores e Jiménez (1999, p. 32), há um consenso em relação à estrutura básica deste tipo de pesquisa:

La investigación cualitativa tiene significados diferentes en cada momento. Una primeira definición, aportada por Denzin y Lincoln (1994:2), destaca que “es multimetódica en el

\footnotetext{
${ }^{3}$ Santo André, São Bernardo do Campo, São Caetano e Diadema: cidades que se desenvolveram na periferia da cidade de São Paulo, habitadas originalmente por operários e pela camada mais pobre da população.
} 
enfoque, implica un enfoque interpretativo, naturalista hacia su objeto de estudio". Esto significa que los investigadores cualitativos estudian la realidad en su contexto natural, tal y como sucede, intentando sacar sentido de, o interpretar, los fenómenos de acuerdo con los significados que tienen para las personas implicadas. La investigación cualitativa implica la utilización y recogida de una gran variedad de materiales - entrevista, experiencia personal, histórias de vida, observaciones, textos históricos, imágenes, sonidos - que describen la rutina y las situaciones problemáticas y los significados en la vida de las personas.

Podemos adicionar ainda que a pesquisa qualitativa coloca o pesquisador no meio da cena investigada (sendo ele mesmo o seu principal instrumento de coleta de dados) tendo o ambiente natural como sua fonte direta de informações. Sendo assim, este tipo de pesquisa supõe o contato direto e prolongado do pesquisador com o ambiente e a situação que está sendo investigada, normalmente por meio do trabalho intensivo de campo. A justificativa para que o pesquisador mantenha um contato estreito e direto com a situação na qual os fenômenos ocorrem naturalmente é a de que estes, bem como a análise dos mesmos, estão diretamente relacionados ao contexto em que ocorrem (Ludke e André, 1986, p.8).

Portanto, a pesquisa qualitativa permite que o pesquisador tente encontrar meios para compreender o significado manifesto e latente das atitudes dos indivíduos, partindo dos pressupostos de que as ações humanas são significativamente influenciadas pelo contexto em que se situam. Ele busca, desta forma, sempre considerar o que se observa como algo dinâmico, global e construído a partir de um processo de interação.

Os estudos qualitativos baseiam-se, sobretudo, na observação participante e na entrevista aberta, buscando um contato direto e pessoal com o universo investigado (Velho, 1978, p. 36).

Nesta dissertação, de cunho etnográfico, de acordo com Spradley, citado por Gómez, Flores e Jiménez (1999, p.44), a etnografia é "uma descrição de um sistema de significados culturais de um determinado grupo". Fizemos, portanto, uso de técnicas etnográficas de observação participante (intensa interação social entre pesquisador e sujeitos) utilizando, para tanto, um diário de campo para anotação das observações e reflexões e um gravador de áudio. 
Os dados coletados são, de início, predominantemente descritivos, buscando com isso descobrir o quê e o como ocorrem as atividades na prática diária da ONG em questão, para a melhoria do grau de letramento de seus participantes. Privilegiam-se, portanto, a descrição e o processo de desenvolvimento mais do que o resultado final, de maneira a encontrar novos conceitos, novas relações e novas formas de entendimento do contexto observado. Assim, buscamos verificar, finalmente, como a leitura se manifesta nas atividades, nos procedimentos e nas interações cotidianas da ONG. Deve-se lembrar sempre que, no plano epistemológico, os estudos qualitativos assumem uma via indutiva dos dados obtidos durante a observação participante.

Utilizamos também a entrevista como instrumento de coleta de dados, na tentativa de capturar a "perspectiva dos participantes", pois segundo Bogdan e Biklen (apud Ludke e André, 1982, p. 12) o "significado" que as pessoas dão às coisas e à sua vida devem ser um foco de atenção especial do pesquisador. Ela abre a possibilidade de perceber como os participantes desses estudos encaram as questões que estão sendo focalizadas (o conceito de leitura, o que significa ser um "bom leitor").

Além das descrições acuradas das situações e das entrevistas, o estudo apresenta outros materiais produzidos pelos sujeitos (produções escritas), que contribuem para ilustrar sua perspectiva. Apresenta, também, análises de documentos que podem fornecer um quadro mais vivo e completo da situação estudada.

Segundo Gómez, Flores e Jiménez (1999, p. 32):

La investigación cualitativa es muchas cosas al mismo tiempo. Es multiparadigmática en su enfoque. Los que la practican son sensibles al valor del enfoque multimetódico. Están sometidos a la perspectiva naturalista y la comprensión interpretativa de la experiencia humana.

Portanto, ao fazer uso de uma variedade de dados e fontes de informação, este método de pesquisa busca retratar o contexto observado de forma mais completa e profunda, revelando a multiplicidade de dimensões presentes numa determinada situação ou problema, 
focalizando-o como um todo. Esse tipo de abordagem enfatiza a complexidade natural das situações, evidenciando a inter-relação dos seus componentes, procurando confrontar os dados obtidos com o conhecimento teórico referente à pesquisa.

Neste trabalho, a pesquisa qualitativa funciona como um estudo de caso das atividades de uma ONG em particular, visando sempre a construir o conhecimento na medida em que se avança na pesquisa, partindo apenas de alguns pressupostos básicos (como a hipótese de que as atividades promovidas pela ONG estudada podem contribuir para a melhoria do grau de letramento e, portanto, da qualidade do ensino nas escolas públicas).

A preocupação central, segundo Ludke e André (1986, p. 17), em desenvolver esse tipo de pesquisa - estudo de caso - é a compreensão de uma instância singular. Isso significa que o objeto estudado é tratado como único, "uma representação singular da realidade que é multidimensional e historicamente situada". No entanto, as autoras complementam que:

\footnotetext{
É possível que o leitor perceba a semelhança de muitos aspectos desse caso particular com outros casos ou situações por ele vivenciados, estabelecendo assim uma "generalização naturalística". O estudo de caso parte do princípio de que o leitor vá usar seus conhecimentos para fazer as generalizações e desenvolver novas idéias, novos significados, novas compreensões. Existe também outro tipo de generalização que fica mais restrito ao âmbito profissional e acadêmico, onde diferentes leitores reconhecem as bases comuns de diferentes estudos de caso desenvolvidos em diferentes contextos. A identificação desses aspectos comuns e recorrentes vai permitir, assim, uma ampliação e maior solidez no conhecimento do objeto estudado.
}

Sinteticamente, podemos dizer que o estudo qualitativo de natureza etnográfica se caracteriza pelos seguintes fatores, de acordo com Atkinson e Hammersley (1999, p. 248), citados por Gómez, Flores e Jiménez (1999, p. 45):

a) Uma forte ênfase na exploração da natureza de um fenômeno social concreto, antes que se possa comprovar hipóteses sobre o mesmo;

b) Uma tendência a trabalhar com dados não estruturados, ou seja, dados que não tenham sido codificados em um conjunto fechado de categorias analíticas; 
c) A investigação de um pequeno número de casos, quiçá somente um, porém em profundidade;

d) A análise dos dados implica a interpretação dos significados e funções dos atos humanos, expressando-os por meio de descrições e explicações verbais, deixando a análise estatística a um plano secundário.

Considerando este "holismo seletivo", nas palavras de Gómez, Flores e Jiménez (1999, p. 45), e uma contextualização determinada na realização da pesquisa de cunho etnográfico, buscamos descrever e analisar os sujeitos desta pesquisa em suas relações sociais nos grupos de leitura, na sede da ONG e na escola, observando sempre os ambientes físicos e as características dos mesmos que facilitam a leitura e o valor que se concede à leitura neste meio social.

\subsubsection{ALGUNS PROBLEMAS NO USO DAS ABORDAGENS QUALITATIVAS E RECURSOS UTILIZADOS PARA MAXIMIZAR A CONFIABILIDADE DOS RESULTADOS}

Como já mencionado anteriormente, a questão mais geral e mais freqüentemente levantada em relação às abordagens qualitativas é a da subjetividade do pesquisador. Assim, segundo Ludke e André (1986, p. 51), reconhecendo a impossibilidade de separar os valores pessoais do processo de pesquisa, devemos ter alguns cuidados especiais no sentido de controlar o efeito da subjetividade. Uma das formas de controle é a revelação, pelo pesquisador, de sua concepção teórica da realidade, de modo que as pessoas possam julgar a sua relevância no desenvolvimento do estudo. Na medida do possível, o pesquisador deve também revelar ao leitor em que medida ele foi afetado pelo estudo, explicando as mudanças porventura havidas nos seus pressupostos, valores e julgamentos. Ou seja, trata-se de um

processo dialético entre sujeito e objeto do conhecimento. É importante que ele deixe claros os critérios utilizados para selecionar certos tipos de dados, e não outros, para observar determinadas situações específicas e não outras, e para entrevistar determinadas pessoas e não outras. 
Os cuidados com a objetividade são importantes porque afetam diretamente a validade do estudo. Por este motivo, Mazzotti e Gewandsznajder (1998, p. 172-174) propõem pelo menos seis itens para a realização de uma pesquisa qualitativa válida:

1. "Permanência prolongada no campo": suficientemente longa para que o pesquisador possa apreender a cultura de uma perspectiva mais ampla, corrigir interpretações falsas ou enviesadas e identificar distorções nas informações apresentadas pelos sujeitos. Um período longo é importante para que o pesquisador veja as coisas acontecerem não uma vez, mas repetidamente.

2. "Checagem pelos participantes": captar os significados atribuídos aos eventos pelos participantes, verificar se as interpretações do pesquisador têm algum sentido para aqueles que forneceram os dados nos quais estas informações se baseiam. A verificação deve ser feita de modo mais completo e formal no final, apresentando-se aos participantes os resultados e conclusões, pedindo que os avaliem quanto à precisão e relevância.

3. "Questionamento por pares": solicitar a colegas não envolvidos na pesquisa, mas que trabalhem no mesmo paradigma e conheçam o tema pesquisado, que apontem falhas, identificando evidências não exploradas e oferecendo interpretações e explicações alternativas àquelas elaboradas pelo pesquisador.

4. "Triangulação dos dados": buscar diferentes maneiras para investigar um mesmo aspecto (comparação e análise de diferentes métodos e materiais recolhidos).

5. "Análise de hipóteses alternativas": procurar interpretações diferentes das suas e tentar confirmá-las ou não.

6. "Análise de casos negativos": a análise de casos que se afastam do padrão pode trazer esclarecimentos importantes e ajudar a refinar explicações e interpretações.

Assim, a partir dessas premissas básicas, levamos em consideração esses tópicos e procuramos, neste estudo, buscar fundamentos para a análise das atividades de leitura realizadas pela ONG BEM. Buscamos verificar seus reflexos na constituição de leitores e o auxílio à constituição de leitores nas escolas públicas do $\mathrm{ABC}$ paulista. 


\subsection{SUJEITOS DA PESQUISA}

Os sujeitos principais da pesquisa fazem parte de um grupo de educandos do $3^{\circ}$ ano do Ensino Médio de uma escola estadual de São Bernardo do Campo, no ABC paulista, além do educador que coordenou o grupo, membro do projeto "Círculo de leitura" organizado e patrocinado pela ONG 6.

O histórico da ONG na qual foi realizada a pesquisa de campo e a maneira como foram travados os primeiros contatos estão relatados no capítulo 6 desta dissertação.

Todos os participantes envolvidos neste projeto são provenientes da rede pública de ensino do $\mathrm{ABC}$ paulista, tendo em comum o fato de se interessarem pela proposta da ONG e de participarem de livre e espontânea vontade das atividades propostas.

A escolha deste grupo de sujeitos deveu-se primeiramente à disponibilidade dos grupos em aceitar a presença da pesquisadora e, posteriormente, por meio da indicação de uma das coordenadoras pedagógicas da ONG. Esta, junto conosco, avaliou com qual grupo de alunos seria mais interessante realizar o acompanhamento. Decidiu-se por um grupo iniciante coordenado por um educador com bastante experiência.

Com relação à ONG, traçamos um perfil do trabalho por meio de uma amostragem, buscando retratar as concepções de leitura dos educandos, bem como dos educadores. Para tanto, o acompanhamento ocorreu por meio da observação participante durante os círculos de leituras e fora deles, nos intervalos e nas outras atividades da ONG, além das entrevistas.

No grupo observado, a coordenação ficou a cargo do educador Renato ${ }^{4}$, aluno de Filosofia da PUC-SP. Este grupo era composto por 7 educandos (dois rapazes e cinco moças) do $3^{\circ}$ ano do Ensino Médio.

\footnotetext{
${ }^{4}$ Os nomes dos sujeitos e das próprias ONGs foram trocados a fim de salvaguardar os participantes desta pesquisa, bem como a integridade desta dissertação.
} 
Além dos educandos, educadores e multiplicadores do grupo mencionado acima, foram considerados participantes desta pesquisa outros educadores, educandos e multiplicadores, bem como as coordenadoras pedagógicas da ONG e uma das professoras, na medida em que, no decorrer das observações, suas participações ocorreram naturalmente por meio de conversas informais e registro de diálogos.

\subsection{TEMPO DE PERMANÊNCIA EM CAMPO}

Segundo teóricos dos métodos qualitativos (Ludke e André, 1986; Wolcott, 1975; Gómez, Flores e Jiménez, 1999), o pesquisador deve realizar a maior parte do trabalho de campo pessoalmente e este trabalho deve durar pelo menos um ano, no caso de pesquisas na área de educação, um ano escolar. Portanto, esta pesquisa teve a duração de um ano e meio, calculado desde o primeiro contato com a ONG em 16 de dezembro de 2005.

Os encontros dos círculos de leitura nas escolas ocorriam semanalmente, com a duração de duas horas. Já as atividades para os educadores e multiplicadores ocorriam na sede da ONG, no bairro de Higienópolis, todas as sextas-feiras e aos sábados o dia inteiro. Os encontros foram observados por nós no decorrer de um ano e meio, sendo que os grupos estudados nas escolas e na sede foram acompanhados semanalmente, porém, somente durante um dos períodos (manhã ou tarde da sexta-feira, e, eventualmente, aos sábados). Desta forma, foi possível participarmos de 38 encontros.

\subsection{ETAPAS DE DESENVOLVIMENTO DA PESQUISA (CRONOGRAMA)}

Orientados pelas etapas propostas por Mazzotti e Gewandsznajder (1998, p. 160) para o desenvolvimento de pesquisas qualitativas, descrevemos brevemente as etapas pelas quais esta pesquisa foi sendo constituída e que são desmembradas e descritas com mais profundidade no corpo desta dissertação.

\subsubsection{FASE DE NEGOCIAÇÃO}

Tendo encontrado uma ONG que tornasse a pesquisa viável, deu-se início à fase de negociação. Esta fase refere-se aos primeiros contatos com a ONG, nos quais pesquisador, 
coordenadoras e participantes foram se conhecendo e estabelecendo relações que possibilitariam a realização da pesquisa.

Neste momento, foi preciso conquistar a confiança da idealizadora do projeto e das coordenadoras para sermos aceitos dentro da organização. Para tanto, participamos como convidados em dois encontros dos círculos de leitura, que se mostrou como o melhor espaço para entender o funcionamento do projeto e conhecer os participantes. Também conversamos informalmente com as lideranças (idealizadora e fundadora do projeto e coordenadoras). Ao mesmo tempo em que avaliávamos o projeto, fomos avaliados pela fundadora do projeto, psicanalista, a fim de constatar se nosso perfil interferiria no andamento dos trabalhos da ONG ou não. E, assim, deu-se início ao trabalho de campo.

Tal como Foote-Whyte (1980, p.79) expôs, é fundamental estabelecer uma relação franca e aberta com as lideranças, uma vez que a aceitação do pesquisador pelo grupo depende muito mais das relações pessoais que se desenvolvem do que de eventuais explicações, sendo crucial obter apoio de indivíduos-chave nas organizações estudadas.

Assim, nesta fase de negociação, estabeleceu-se uma relação mais intensa com as coordenadoras do projeto do que com os próprios participantes (educandos e educadores). $\mathrm{Na}$ terceira visita à ONG, passamos uma tarde conversando com uma das coordenadoras, procurando obter mais informações sobre o trabalho da ONG e esclarecendo possíveis dúvidas que a coordenação tivesse em relação à pesquisa que seria realizada. Nesta fase, foram feitas quatro visitas à ONG, antes de começar o período exploratório.

\subsubsection{FASE INICIAL DA PESQUISA - PERÍODO EXPLORATÓRIO}

O período exploratório durou cerca de dois meses, durante os quais visitamos tanto as atividades na sede da ONG como numa das escolas estaduais de São Bernardo do Campo. Esse período foi importante para proporcionar, por meio de nossa imersão no contexto, uma visão geral do problema considerado, contribuindo para a focalização de questões e para a 
identificação de sujeitos (Mazzotti e Gewandsznajder, 1998, p. 150). Desta forma, buscamos obter informações relevantes para focalizar o estudo e orientar decisões iniciais.

Seguindo o conselho de Foote-Whyte (1980, p.81), procuramos não discutir com as pessoas, julgá-las ou parecer muito contestadores, esforçando-nos para aceitar as pessoas e sermos aceitos por elas. Desta forma, de início, não fizemos entrevistas formais, mas obtivemos muitas informações por meio de conversas informais que nos auxiliaram a orientar o estudo e começar a criar hipóteses, esperando sempre o momento apropriado para perguntar e o modo oportuno de perguntar.

Nesta etapa, registramos as primeiras observações no diário de campo, com a finalidade de adquirir maior conhecimento sobre o fenômeno e possibilitar a seleção de aspectos que seriam mais sistematicamente investigados, para compreender e interpretar o fenômeno estudado.

Podemos adiantar que foi neste período que começamos a criar um esquema de entrevista como forma de tentar descobrir a opinião dos participantes sobre questões que julgamos relevantes como: o que é ser um bom leitor, para que serve a leitura, quais as experiências prévias de leitura em sala de aula e fora dela, como eles lêem etc. Neste momento, também levantamos a hipótese, a partir das conversas informais com os multiplicadores, de que talvez o que os atraía para os círculos de leitura não fosse a leitura propriamente dita, mas sim o prazer emocional de compartilhar opiniões, ter a possibilidade de falar sobre si mesmo e de pertencer a um grupo.

\subsubsection{PROCEDIMENTOS PARA COLETA DE DADOS}

Como já afirmado anteriormente, as pesquisas qualitativas são caracteristicamente multimetodológicas, ou seja, usam uma grande variedade de procedimentos e instrumentos de coleta de dados (Mazzotti e Gewandsznajder, 1998; Gómez, Flores e Jiménez, 1999). Desta forma, indicamos aqui os procedimentos utilizados nesta pesquisa: 


\title{
1.6.3.1 OBSERVAÇÃO PARTICIPANTE
}

A observação participante tem papel fundamental e central nas pesquisas qualitativas, lembrando que, por meio dela, segundo Mazzotti e Gewandsznajder (1998, p. 166-167),

\footnotetext{
o pesquisador se torna parte da situação observada, interagindo por longos períodos com os sujeitos, buscando partilhar o seu cotidiano para sentir o que significa estar naquela situação. A importância atribuída à observação participante está relacionada à valorização do instrumental humano, característica da tradição etnográfica.
}

Uma vez que o cerne da pesquisa qualitativa é a descrição e a compreensão das atitudes/ações de um dado contexto, a observação participante possui muitas vantagens, pois

\begin{abstract}
independe do nível de conhecimento ou da capacidade verbal dos sujeitos, ao mesmo tempo em que permite confirmar, na prática, a "sinceridade" de certas respostas que, às vezes, são dadas só para "causar boa impressão", permitindo identificar também atitudes não-intencionais e explorar tópicos que os sujeitos não se sentem à vontade para discutir e finalmente permite também o registro das ações em seu contexto temporal-espacial. (Mazzotti e Gewandsznajder, 1998, p. 164).
\end{abstract}

O fato de esse tipo de observação não ser estruturada ou pré-estabelecida corrobora a afirmação de que pesquisas do tipo qualitativo tendem a partir menos de estereótipos do que outros métodos de pesquisa, e, assim, contemplar o contexto de maneira múltipla e surpreendente.

A observação feita por um longo período de tempo torna-se objeto de uma reflexão sistemática que pretende impedir que o conhecimento do pesquisador seja seriamente comprometido pela rotina, hábitos, estereótipos (Velho, 1978, p.41). É importante lembrar, no entanto, que se trata de uma interpretação e que, por mais que se tenha procurado reunir dados "verdadeiros" e "objetivos" sobre a vida daquele universo, a subjetividade do pesquisador está presente em todo o trabalho (Velho, 1978, p. 43) - a introspecção e a reflexão pessoal têm papel importante na pesquisa de cunho etnográfico. 
A experiência direta promovida pela observação participante é sem dúvida o melhor teste de verificação da ocorrência de um determinado fenômeno, pois permite também que o observador chegue mais perto da "perspectiva dos sujeitos", um importante alvo deste tipo de abordagem (Ludke e André, 1986, p. 26).

No mais, as técnicas de observação são extremamente úteis para "descobrir" aspectos novos de um problema, auxiliando o pesquisador a refletir sobre os propósitos de seu trabalho, sobre as relações entre o que observa e seus conhecimentos teóricos, além de permitir a coleta de dados em situações em que são impossíveis outras formas de comunicação. Assim, torna-se possível manter uma perspectiva mais ampla, sem se desviar demasiado de seus focos de interesse.

Segundo Bogdan e Biklen (apud Ludke e André, 1982, p.12), o conteúdo das observações envolve uma parte descritiva e uma mais reflexiva. A parte descritiva compreende um registro detalhado do que ocorre no campo (descrição dos sujeitos; reconstrução de diálogos; descrição de locais; descrição de eventos especiais; descrição das atividades; as atitudes do observador) e a parte reflexiva inclui as observações pessoais do pesquisador, feitas durante a fase de coleta: suas especulações, sentimentos, problemas, idéias, impressões, pré-concepções, dúvidas, incertezas, surpresas e decepções.

O registro das observações foi feito em um caderno no qual foram registrados os contextos das observações, as reflexões, a duração das atividades etc. Essas anotações foram feitas em geral no momento da observação, buscando com isso maior acuidade. O caderno constituiu a forma principal de registro dos dados e das notas de campo. Eventualmente, foram realizadas gravações dos encontros.

\subsubsection{ENTREVISTAS EM PROFUNDIDADE}

Foram realizados dois tipos de entrevistas: as semi-estruturadas e as não-diretivas. As não-diretivas são aquelas realizadas de maneira informal, como uma conversa, permitindo que o entrevistado fale livremente, contribuindo assim para que o pesquisador apreenda os sistemas de valores, de normas e representações, de símbolos próprios do grupo estudado, uma vez que, como afirma Michelat (1982, p.193), 
(...) a informação conseguida pela entrevista não-diretiva é considerada como correspondendo a níveis mais profundos, isto porque parece existir uma relação entre o grau de liberdade deixado ao entrevistador e o nível de profundidade das informações que ele pode fornecer.

Tais informações diferenciam-se daquelas conseguidas por meio de questionários e entrevistas estruturadas que são, na maioria das vezes, mais superficiais, estereotipadas e mais racionalizadas (Michelat, 1992, p.193).

Em geral, estas entrevistas não-diretivas foram realizadas em situações informais, antes do início dos círculos, durante os almoços, após o encerramento das atividades ou andando pelos corredores.

Por sua vez, as entrevistas semi-estruturadas foram realizadas com gravadores e partiram de um roteiro de perguntas; assim, fizemos perguntas específicas, mas também permitimos ao entrevistado responder em seus próprios termos, buscando não interferir. A entrevista semi-estruturada se desenrola, portanto, a partir de um esquema básico, embora não aplicado rigidamente, favorecendo ao entrevistador fazer as necessárias adaptações.

As perguntas foram elaboradas de maneira a não antecipar ou forçar a resposta do sujeito, deixando margem de liberdade para a resposta. Tendo em mente que na entrevista a relação que se cria é de interação, procurou-se construir um clima de estímulo e de aceitação mútua, para que as informações fluíssem de maneira espontânea e autêntica. Portanto, antes do início das entrevistas, sobretudo com os educandos e com os multiplicadores, enfatizamos que não havia respostas certas ou erradas e que o objetivo era descobrir as opiniões dos sujeitos e seus pontos de vista sobre os assuntos tratados e ouvir suas histórias de vida.

Segundo Ludke e André (1986, p. 34),

a grande vantagem da entrevista sobre outras técnicas é que ela permite a captação imediata e corrente da informação desejada, praticamente com qualquer tipo de informante e sobre os mais diversos tópicos. Pode permitir o aprofundamento de pontos levantados por outras técnicas de coleta de alcance mais superficial, como o questionário. 


\subsubsection{PRODUÇÕES ESCRITAS E DOCUMENTOS}

$\mathrm{Na}$ presente pesquisa, foram recolhidos documentos, entendidos aqui como "quaisquer materiais escritos que possam ser usados como fonte de informação sobre o comportamento humano", tal qual proposto por Phillips (apud Ludke e André, 1986, p. 38).

A coleta e posterior análise são técnicas valiosas de abordagem de dados qualitativos. Segundo as autoras:

os documentos constituem uma fonte estável, perene e rica, de onde podem ser retiradas evidências que fundamentem afirmações e declarações do pesquisador. Ratificando e validando informações obtidas por outras técnicas de coleta de dados.

Desta forma, foram coletadas e analisadas as produções escritas dos sujeitos sobre os encontros nos círculos de leitura, os textos propostos pelo projeto para serem lidos e os documentos criados pela própria ONG (seus próprios questionários, sua proposta de trabalho, refletindo sempre sobre os procedimentos e / ou fontes utilizadas e os propósitos com base nos quais foram elaborados).

\subsubsection{INVESTIGAÇÃO FOCALIZADA: COLETA SISTEMÁTICA DE DADOS}

Esta é a fase principal da pesquisa que teve duração de aproximadamente um ano. Neste período, além da observação constante, fizemos uso de instrumentos auxiliares, como roteiros de entrevista, gravações de encontros, produções escritas e formulários de observação.

Assim como propõem Ludke e André (1986, p. 16), nesta fase, procuramos descrever o que observamos na tentativa de encontrar os princípios subjacentes ao fenômeno estudado e de situar as várias descobertas num contexto mais amplo:

Esta fase envolve o desenvolvimento de teorias, um processo que vai sendo preparado durante todo o desenrolar do estudo. Partindo de um esquema geral de conceitos, o pesquisador procura testar constantemente as suas hipóteses com a realidade observada diariamente. Essa interação 
contínua entre os dados reais e as suas possíveis explicações teóricas permite a estruturação de um quadro teórico dentro do qual o fenômeno pode ser interpretado e compreendido.

Neste momento, também procuramos testar e refinar as explicações teóricas, encontrando ou não evidências que confirmassem ou negassem nossas hipóteses (Becker, apud Ludke e André, 1986, p. 16), uma vez que descobrir evidências positivas e negativas pode reduzir o grau de inferência dos julgamentos na observação participante. Intencionamos, desta forma, ampliar ao máximo possível a descrição do que é observado e colocá-lo em contexto.

\subsubsection{PROCEDIMENTOS PARA ANÁliSE DOS DADOS (ANÁLISE DE CONTEÚdO COMO MÉTODO DE PESQUISA)}

Sendo o intuito desta pesquisa a descrição de como a leitura vem sendo trabalhada nos diversos espaços da ONG em questão (qual o seu espaço, o que é que se faz com ela, quais os materiais utilizados, qual a visão de seus participantes sobre leitura e quais as implicações e resultados decorrentes do modo de ler proposto pela ONG na constituição dos participantes do projeto), analisamos se as atividades de leitura propostas pela ONG colaboram para a constituição de novos leitores.

Buscando cumprir o objetivo de que os dados coletados possam vir a orientar a construção de novos saberes sobre a constituição de leitores nestes novos espaços de educação não-formal, analisamos estes dados, sobretudo, a partir do que se chama de triangulação das fontes.

\subsubsection{TRIANGULAÇÃO DAS FONTES - OBSERVAÇÃO, MATERIAIS ESCRITOS E ENTREVISTAS}

A triangulação de dados é a análise comparativa dos materiais recolhidos (observações, entrevistas, produções escritas, documentos oficiais), buscando encontrar neles tanto pontos comuns como pontos de divergência entre o que foi observado pela pesquisadora e o proposto ou afirmado por seus participantes. Tal procedimento é realizado, uma vez que 
nem sempre, por melhor que sejam as intenções dos participantes, aquilo que é afirmado por eles corresponde ao que ocorre no cotidiano das atividades.

Esta forma de análise é realizada de forma interativa, no decorrer da coleta de dados, acompanhando todo o processo de investigação.

É importante ressaltar aqui que, dentro da triangulação das fontes, subjacente a ela, está a indicação de paradigmas que orientam este estudo. Ou seja, a partir das análises feitas, buscamos estabelecer ligações entre elas e o referencial teórico que sustenta esta pesquisa, visando a destacar os principais achados das observações, bem como construir um conjunto de categorias descritivas para facilitar a compreensão dos dados.

Este conjunto de categorias descritivas pode também ser chamado de "unidades de análises", que é a forma pela qual organizamos os dados para efeito de análise, de acordo com Mazzotti (1998, p. 170):

\begin{abstract}
As pesquisas qualitativas tipicamente geram um enorme volume de dados que precisam ser organizados e compreendidos. Isto se faz através de um processo continuado em que se procura identificar dimensões, categorias, tendências, padrões, relações, desvendando-lhes o significado. À medida que os dados vão sendo coletados, o pesquisador vai procurando identificar temas e relações, construindo interpretações e gerando novas questões e / ou aperfeiçoando as anteriores, o que, por sua vez, o leva a buscar novos dados, complementares ou mais específicos, que sustentam suas interpretações.
\end{abstract}

Certamente, a categorização, por si mesma, não esgota a análise. É, portanto, necessário que o pesquisador vá além, buscando acrescentar algo à discussão já existente sobre o assunto focalizado, ultrapassando os dados, tentando estabelecer conexões e relações que possibilitem a proposição de novas explicações e interpretações. Esse acréscimo pode significar desde um conjunto de preposições bem concatenadas e relacionadas que configuram uma nova perspectiva teórica até o simples levantamento de novas questões e questionamentos a serem mais sistematicamente explorados, o que será realizado nos capítulos 6 e 7 . 


\subsubsection{ANÁLISE DE PRODUÇÕES ESCRITAS}

A análise das produções escritas, dentro deste processo de triangulação das fontes, foi realizada a partir de classificações de seu conteúdo. Isso ocorreu após selecionarmos os tipos de documentos que seriam estudados e analisarmos o conteúdo.

Essa classificação tem como objetivo facilitar a observação e a exploração das ligações entre os diversos itens da pesquisa, estabelecendo relações e associações e passando então a combiná-los, separá-los ou reorganizá-los.

Vale ressaltar também que a análise documental busca identificar informações factuais nos documentos a partir de questões ou hipóteses de interesse. 


\section{CAPÍTULO 2 - A LEITURA DE TEXTOS LITERÁRIOS COMO PRÁTICA SOCIAL}

Há algum tempo, uma diversidade de teóricos, entre eles Steiner (1998) e Arendt (2000), vêm expondo o que chamam de crise da linguagem e da cultura na pós-modernidade. Iniciamos esta discussão teórica refletindo sobre em que medida esta preocupação com uma possível crise cultural é relevante e, principalmente, por que, dentro do universo da cultura, possuir o domínio da leitura da palavra escrita como prática social é importante para que os homens possam exercer plenamente sua cidadania, bem como usufruir os bens culturais produzidos pela sociedade. Desta forma, buscamos explicitar o papel social da leitura em geral (textos não-literários) e, especificamente, da literatura, e sua importância no processo de humanização do homem moderno. No entanto, antes de iniciarmos esta discussão, faremos uma delimitação do campo da leitura, da maneira como está sendo considerada no presente trabalho.

\subsection{DELIMITANDO O CAMPO DA LEITURA}

Quando nos perguntamos se ler é importante, diversas distinções são necessárias. Trata-se da leitura do não-verbal por meio de imagens, sons, olhares, gestos, movimentos etc.? Ou do verbal? Nesta dissertação, tratamos da leitura da palavra, da modalidade escrita da língua.

Para Semeghini-Siqueira (2006, p. 175-177) podemos trabalhar com textos voltados ao pilar da "magia/estética" ou ao da "informação",

uma vez que os autores de textos literários e/ou textos informativos os concebem de modos diferenciados, são produções escritas que detêm especificidades.

Os textos informativos são predominantemente voltados para a construção do conhecimento e "ampliam a competência para o exercício da cidadania". Neste pilar, um conjunto de palavras está subjacente às práticas educacionais: "instrumentação, objetividade almejada, raciocínio, argumentação, crítica/opinião, atenção e fluência”. No que tange aos 
processos envolvidos no ato de ler, a Psicolingüística recorre especialmente a textos informativos.

Para a autora, o outro pilar, o da "magia/estética", contempla a diversidade cultural em que os textos são predominantemente voltados para a Arte: os textos literários. Neste caso, um outro conjunto de palavras está subjacente às práticas educacionais: “imaginação, subjetividade, desejo/prazer, sedução, criação e fluência". Assim sendo,

será imprescindível que se leve em consideração a especificidade do texto literário, e se Literatura é Arte, como tal precisa ser compreendida e tratada.

Desta maneira, compreendemos a leitura, neste trabalho, como a leitura da palavra escrita, levando em consideração os pilares da "informação" e da "magia/estética", focalizando, sobretudo, o último, no qual se inserem os textos literários.

\subsection{A LEITURA E SEU PAPEL SOCIAL AO LONGO DA HISTÓRIA: EM QUE MEDIDA LER É IMPORTANTE?}

Em "Compreendendo a leitura", Frank Smith afirma que a leitura possui conseqüências particulares deste tipo de experiência, tal qual o aumento da memória e do conhecimento específico. Como para o teórico a experiência sempre resulta em aprendizado, a leitura leva a mais conhecimento sobre a própria leitura, incluindo o aumento de vocabulário, o desenvolvimento de melhores "habilidades de compreensão" e melhor desempenho acadêmico em geral. Assim, para Smith (2003, p. 224), a leitura "tornaria as pessoas mais espertas":

(...) a leitura contribui para a crescente habilidade de uma criança para compreender, permitindo a elaboração da estrutura complexa de categorias, lista de características e inter-relacionamentos que constituem a teoria de mundo de cada criança.

Desta forma, a leitura possuiria um alcance ainda maior. Uma vez que outras coisas são aprendidas por meio da leitura, esta seria "o clube dos clubes, a única possibilidade de muitas experiências de aprendizado" (Smith, 2003, p. 238) que ultrapassaria a própria leitura e atingiria um nível social e humanista fundamental na formação do homem. 
Por esta e outras afirmações é bastante comum ouvirmos o discurso de que sem um grau mínimo de letramento, as pessoas deixam de usufruir efetivamente dos bens culturais produzidos pela sociedade e são impedidas de exercerem direitos inalienáveis, uma vez que não vivenciam significativas práticas sociais que poderiam implicar a sua inserção social, ficando à margem das possibilidades constituídas a partir da leitura e da escrita (Tezzari, 2005, p. 54).

Podemos dizer que este discurso nasceu junto ao ideário Iluminista que já no século XVIII defendia, segundo Enzensberger (1985, p.45), que "a infelicidade social tem por base não apenas os privilégios materiais como também os imateriais dos dominantes (...)”. Assim, os intelectuais iluministas

acreditavam que a imaturidade do povo se devia não apenas à sua supressão política e sua exploração econômica, como também à sua ignorância. Partindo dessas premissas, gerações futuras concluíram que a habilidade de ler e escrever é parte essencial de uma existência humana digna.

O domínio da leitura, então, além de humanizar o homem, também se tornou um índice que nos auxiliou a estabelecer relações hierárquicas de poder na sociedade ocidental. Desta forma, percebe-se ao longo da história que o ato de ler, por muito tempo, esteve restrito à elite, transformando-se em um fenômeno social e econômico (Steiner, 1970, p. 150). Por isso, numa tentativa de socializar a leitura e, desta forma, colocar todos os seres humanos numa situação igualitária, libertando-os do que eles consideravam ignorância e opressão, os iluministas propuseram o ensino público e democrático que foi posteriormente instituído por Napoleão Bonaparte na França e depois se espalhou pelo mundo.

Evidentemente, apesar de ter em vista a importância do domínio da leitura, não pretendemos com isso desvalorizar as culturas orais, nem muito menos legitimar preconceitos contra os analfabetos e/ ou sociedades de culturas orais. Como coloca Galvão e Di Pierro (2007, p. 13):

(...) nem todos os povos partilham a mesma experiência histórica ou condições econômicas e culturais similares. Isso torna problemática a generalização das premissas relacionadas à alfabetização, na medida em que obscurecem a compreensão dos grupos sociais entre os quais predominam as formas 
orais de comunicação, o que deixa terreno aberto ao estabelecimento de hierarquias sobre as quais se constróem preconceitos.

E lembram ainda que "o analfabetismo é expressão de processos de exclusão sociocultural, que não afetam a competência intelectual ou o discernimento moral dos sujeitos" (2007, p. 26); ou seja, seria preconceituoso imputar à pessoa não-alfabetizada privação de consciência e responsabilidade no sentido de exercer sua cidadania e participar politicamente da sociedade. Paulo Freire $(2006,2002)$ nos lembra que a leitura do mundo precede sempre a leitura da palavra, e é esta leitura do mundo que nos conscientiza e nos torna seres políticos.

Mas, obviamente, concordamos que a alfabetização e a educação são extremamente importantes como um dos componentes do "processo de conquista de direitos sociais, civis e políticos (um instrumento de cidadania)”, (Galvão \& Di Pierro, 2007, p.77).

Assim, inseridos nesta sociedade - ocidental e letrada - percebemos que até hoje leitura, cultura e educação passaram a caminhar juntas e, muitas vezes, no decorrer da história, um conceito confundiu-se com o outro. Com o tempo, saber ler e consumir cultura passou de um valor intelectual e humanístico a um valor cívico e, posteriormente, no mundo burguês, transformou-se em uma moeda, ou como coloca Arendt (2000, p. 254), em uma "arma" na luta por posição social ou um valor de esnobismo.

De acordo com Alberto Manguel (2004, pp.183, 242), foi no século XIV que os livros passaram das mãos exclusivas da nobreza e do clero para a burguesia e, assim, a leitura passou a ter valor social:

\footnotetext{
A aristocracia tornou-se o modelo para os nouveaux riches: se os nobres liam então eles também leriam (habilidade que os burgueses haviam adquirido na condição de comerciantes); se os nobres dormiam sobre madeira esculpida e entre panos decorados, então eles também o fariam. Ser visto como dono de livros e leitos ornamentados tornou-se sinal de posição social. (...) A simples posse de livros implica uma posição social e uma certa riqueza intelectual.
}

Esta última transformação do ato de ler em moeda social, que permanece, num certo sentido, até os dias de hoje, foi impulsionada principalmente pela pós-modernidade e pela pós-cultura (Steiner, 1970), o que culminou em uma visão burguesa e pragmática do mundo: 
dentro do quadro social fortalecido pela pós-modernidade, no qual a ética da rapidez, da competição, da hiper-valorização da matéria e do individualismo imperam, a mass mídia (encabeçada pela televisão) surgiu em função de fornecer o máximo de impacto e a obsolescência imediata, onde tudo é essencialmente efêmero. Assim, acabam faltando "padrões ao homem da massa que consome incessantemente sem julgar e permanece alienado do mundo, perdido em seu egocentrismo" (Arendt, 2000, p. 251). Para este homem, a leitura e a cultura não possuem valor humanístico, nem tampouco cívico, e sim social e econômico. Ambas tornaram-se armas da elite para subjugar o povo, elite esta que entende a cultura como entende todas as outras coisas "em termos de utilidade imediata e de valores materiais" (Arendt, 2000, p. 256). Segundo a autora (2000, p.254), a grande problemática da visão pós-moderna da cultura é exatamente a de que

a sociedade começou a monopolizar a "cultura" em função de seus próprios objetivos, tais como posição social e status. (...) Na luta por posição social a cultura começou a desempenhar enorme papel como uma das armas.

Portanto, ao mesmo tempo em que podemos observar que a leitura, como elemento intrínseco do universo cultural, foi, principalmente nas camadas populares, desvalorizada em detrimento do que comumente chamamos de mass mídia, observamos, também, que a leitura foi, por outro lado, super-valorizada (como objeto de ascensão social) por ter se tornado cada vez mais uma atividade elitista e hermética, olhada com certa reverência por aqueles que se encontram encarcerados na cultura de massa.

\subsection{PANORAMA HISTÓRICO DA LEITURA NO BRASIL E SEU VALOR NAS POLÍTICAS PÚBLICAS NACIONAIS}

Tendo em vista estes problemas que o conceito de leitura vem enfrentando na sociedade pós-moderna, podemos adicionar a eles as questões específicas da história do ensino da leitura no Brasil para buscar entender como chegamos ao panorama descrito na introdução deste trabalho e qual a importância e valor que a leitura tem na sociedade brasileira.

De acordo com Lajolo \& Zilberman (2003, p. 125), a história da formação da leitura no Brasil inicia-se em 1808 com a vinda da família real, e com ela a instituição de políticas 
educacionais, escolas, a fundação da primeira biblioteca nacional, bem como a liberação do funcionamento das gráficas no país (que antes eram proibidas, constituindo talvez o principal fator responsável pelo retardo e precariedade das práticas de leitura na sociedade brasileira).

Desde 1808, no entanto, o ensino da leitura no Brasil parece vir enfrentando os mesmos obstáculos. No início, a produção de livros estava intrinsecamente ligada à política, uma vez que as gráficas existentes pertenciam ao governo / Estado (2003, p.121) e este, por meio de seus censores, decidiam o que publicar. No quadro atual, a questão editorial não está mais associada ao Estado, mas é criticada por Silva (1999), que acusa os editores de pensarem que "a simples produção de livros pode ser encarada como condição suficiente para a dinamização da leitura e educação de leitores" (p.15) e de "engambelar os professores com manuais didáticos de qualidade duvidosa e, desta forma, em iludir os estudantes com livros didáticos" (p.15). Em geral, de acordo com Silva (2003, p.17), os editores tendem a trabalhar tendo em vista o público já consolidado e não se preocupam com projetos para ampliar o número de leitores.

No que se refere às escolas, de acordo com Lajolo \& Zilberman (2003), estas também surgiram de maneira precária, em más instalações, com professores despreparados, sem formação e mal remunerados. Em 1849, segundo as autoras (2003, p. 143), Primitivo Moacyr afirmou:

O professor dá lições, como dava o mestre com quem aprendeu. Os métodos novos usados em outras partes, com tanto proveito, lhes são desconhecidos. A raridade dos livros, a dificuldade de obtê-los e o preço excessivo que custam, não permitem a um empregado de tão tênues vencimentos adquiri-los.

Pode-se perceber que desde o início da história do ensino no Brasil os professores são pouco valorizados e têm sua auto-estima minada. Segundo Silva (1999, p.22-23):

Em termos históricos, a perda de dignidade dos professores, gerando conseqüências negativas ao nível de sua formação e prática profissional, representa, de fato, um bloqueio ao pleno exercício das suas cidadanias. Mais especificamente, eles são tão influenciados pela ideologia do dom, do sacrifício e/ou sacerdócio, que passam a conviver com uma ampla gama de deveres, normas, obrigações, abnegações e sublimações e, conseqüentemente, vêem-se praticamente obrigados a se encaixar num campo restrito de direitos. 
Evidentemente, Silva (1999, p. 26) completa que:

Sem dúvida a condição básica para uma mudança dessa situação está diretamente relacionada com a recuperação da dignidade do trabalho na área do magistério: sem salários condignos e sem infraestrutura adequada para o exercício profissional, todos os caminhos cairão no romantismo barato ou continuarão desembocando no estatuário das lamentações.

Para o autor (2003, p.37), no entanto, a escola brasileira continua esquecida e abandonada. Se a escola está esquecida, concluímos que o ensino da leitura como ato político também está e refletimos sobre a importância de tudo isto para o estado brasileiro. Paulo Freire (2006, p. 9) lembra que "em uma sociedade que exclui dois terços da sua população (em 1993) (...) é urgente que a questão da leitura e da escrita seja vista enfaticamente sob o ângulo da luta política (...)”.

A própria Biblioteca Real, fundada em 1814, apesar da sua excelência de serviço e material, carecia de novidades no acervo e de freqüentadores (p. 177, 180).

Após esse percurso por alguns tópicos da história e dentro do quadro atual em que se insere a leitura no mundo e no Brasil, somos forçados a procurar um outro lugar para a literatura (como leitura literária). Assim, tentando evitar a transformação da arte em mera moeda para a compra de posição social, e, ao mesmo tempo, buscando valorizá-la como ato criador, político e de conhecimento, como coloca Freire (2006, p.19), encontramos teóricos que nos guiam e defendem a literatura como arte, mas, sobretudo, como um direito e como um elemento de força considerável na formação do homem e de sua humanidade.

\subsection{LENDO LITERATURA E HUMANIZANDO-SE}

Buscando reviver a idéia, de origem iluminista, de que a leitura e o desenvolvimento intelectual e, principalmente, humano, propiciado por ela, são fundamentais para a luta contra a opressão, alguns intelectuais com um viés social mais evidente, como Antonio Candido (1972, 1995), lutam a favor da leitura literária em uma sociedade cada vez mais massificada e regida por valores neo-liberais, que exige pragmatismo, função ou finalidade imediata para tudo, super-valorização do produto final. É o que comumente se denomina práxis utilitária. 
Cobra-se, assim, uma função para a literatura: por que ela seria também fundamental? Quais seriam suas funções? Em que medida ler obras literárias é importante?

Poderíamos começar afirmando que talvez a qualidade principal da arte seja trazer uma beleza que transcende necessidades e funções (Arendt, 2000, p. 261), mas não podemos negar-lhe outras qualidades como a humanização do espírito, na medida em que ela ensina, educa e aperfeiçoa, mesmo não tendo, por vezes, esta intenção. A arte, e neste caso específico a literatura, possui elementos que se opõem aos valores pragmáticos da pós-modernidade, uma vez que nela se busca a humanização do homem coisificado, o desenvolvimento de seu espírito, a união dos homens por meio do conhecimento e do patrimônio / herança cultural da humanidade.

Ao focalizar a leitura, portanto, no pilar da "magia/estética", conduzimos finalmente a nossa discussão a partir de Antonio Candido $(1972,1995)$, autor de textos fundamentais para pensarmos a literatura e seu papel. Ele defendeu em seus textos que a literatura possui "иma função humanizadora e confirma a humanidade no homem, pois o exprime e o forma também”.

Primeiramente, segundo Candido (1995, p. 242), a literatura, como propôs Todorov (1990, p. 27), "uma elaboração estética para a elevação do espírito", possuiria um papel importante na saúde psíquica do homem, pois responde a uma necessidade universal de ficção e de fantasia que é coextensiva a todos nós, uma vez que ninguém passa um dia sem consumir algum tipo de ficção (seja na televisão, em uma piada, no devaneio etc.).

A literatura seria, então, uma das formas mais ricas de sistematizar a fantasia. Umberto Eco (2003, p. 227) ainda corrobora esta afirmação de Candido, quando diz que contar e ouvir histórias é uma função biológica, existe intrinsecamente no homem.

Portanto, ao imaginar histórias, o homem estaria, de um modo figurado, explicando ou buscando razões de ser do mundo físico e social (Candido, 1972, p. 805).

Desta forma, a literatura seria um bem incompressível (do qual não se pode abrir mão), pois garante a integridade espiritual, assim como o direito à crença, à opinião, ao lazer e à arte em geral. Para Candido (1995, p. 241), a necessidade de fruição da literatura como 
fantasia não poderia deixar de ser satisfeita "sob pena de desorganização psíquica pessoal ou frustração mutiladora”.

Além da função psíquica, uma segunda função da literatura seria propriamente a educacional (Candido, 1995, p.244), uma vez que a instrução sempre se baseou nas letras (linguagem escrita), e a formação do homem sempre se relacionou diretamente ao humanismo e à literatura. Porém esta função educacional não seria um "apêndice da instrução moral e cívica", pois segundo o autor, a literatura

age com o impacto indiscriminado da própria vida e educa como ela, com altos e baixos, luzes e sombras (...) ela não corrompe nem edifica, mas trazendo livremente em si o que chamamos o bem e o que chamamos o mal, humaniza em sentido profundo, porque faz viver.

Candido (1972, p. 804), em outra passagem, complementa:

(...) as camadas profundas da nossa personalidade podem sofrer um bombardeio poderoso das obras que lemos e que atuam de maneira que não podemos avaliar. Talvez os contos populares, as historietas ilustradas, os romances policiais ou de capa e espada, as fitas de cinema atuem tanto quanto a escola e a família na formação de uma criança e de um adolescente.

Assim, a literatura, além de satisfazer a necessidade universal de fantasia, contribui para a formação da personalidade e é também uma forma de conhecimento do mundo e do ser, pois representa de maneira cognitiva ou sugestiva a realidade do espírito, da sociedade e da natureza (Candido, 1995, p. 243).

Nelly Novaes Coelho (2002, pp. 29 e 32), ao falar especificamente da literatura infantil, ainda completa:

Na verdade, desde as origens, a literatura aparece ligada a essa função essencial: atuar sobre as mentes, nas quais se decidem as vontades ou as ações; e sobre os espíritos, nos quais se expandem as emoções, paixões, desejos, sentimentos de toda ordem... No encontro com a literatura (ou com a arte em geral), os homens têm a oportunidade de ampliar, transformar ou enriquecer sua própria existência de vida, em um grau de intensidade não igualada por nenhuma outra atividade (...) dentro do sistema de vida contemporânea (pressionado pela imagem, pela velocidade, pela superficialidade dos contatos humanos e da comunicação cada vez mais rápida e aparente...) acreditamos que a literatura (para crianças ou adultos) precisa urgentemente ser descoberta, muito menos como mero entretenimento (pois deste se 
encarregam com mais facilidade os meios de comunicação de massa), e muito mais como uma aventura espiritual que engaje o eu em uma experiência rica de vida, inteligência e emoções.

Ao organizar idéias de maneira literária, preocupando-se com a forma para se criar o efeito estético inerente a toda obra de arte, a literatura também nos torna mais capazes de ordenar a nossa própria mente e sentimentos, ou seja, nossa visão do mundo, o que já seria também, por si, um elemento humanizador (Candido, 1995, pp. 245-256):

A organização da palavra comunica-se ao nosso espírito e o leva, primeiro, a se organizar, em seguida, a organizar o mundo.

Ademais, à parte a forma e o elemento estético, a literatura traz consigo temas que fazem parte do nosso universo e pode funcionar, tal qual afirmou Antonio Candido (1995, p. 256), como um "instrumento consciente de desmascaramento", trazendo à tona questões sociais, sentimentais, políticas, raciais, sexuais etc. que freqüentemente a sociedade tenta ignorar, mas que são, na maioria das vezes, essenciais para que o elemento humano permaneça em meio ao caos da vida moderna e cotidiana.

Assim a literatura seria um elemento importante de humanização, uma vez que humanizar é, segundo Candido (1995, p. 249):

um processo que confirma no homem aqueles traços que reputamos essenciais, como o exercício da reflexão, a aquisição do saber, a boa disposição para com o próximo, o afinamento das emoções, a capacidade de penetrar nos problemas da vida, o senso de beleza, a percepção da complexidade do mundo, dos seres, o cultivo do humor.

\subsection{PAPEL SOCIAL DA LITERATURA: ESTE DIÁLOGO HUMANIZADOR}

"Camarada, isto não é um livro, Quem toca nisto, toca em um homem"

Walt Whitman, Folhas da relva, 1860 
Tendo em vista este caráter humanizador da literatura, por meio das reflexões de Antonio Candido, percebe-se o alcance do ato de ler, tanto para o indivíduo quanto para a sociedade na qual este se insere.

A literatura, cumprindo sua função de "equilíbrio psíquico", é, para Candido (1995, p.243), o sonho acordado das civilizações: "assim como não é possível haver equilíbrio psíquico sem o sonho durante o sono, talvez não haja equilíbrio social sem a literatura".

Neste sentido, segundo Smith (2003, p. 214):

A leitura não é diferente, em essência, de qualquer outra manifestação de atividade pensante - mas pode ser a forma mais natural e satisfatória de pensamento a nós disponível. Como Harold Rosen (1986) e outros têm seguidamente apontado, o cérebro humano é, essencialmente, um dispositivo de narrativa. Funciona à base de histórias. $\mathrm{O}$ conhecimento que armazenamos no cérebro, em nossa "teoria do mundo", está amplamente na forma de histórias. (...) O pensamento alimenta-se de histórias, na construção e exploração de padrões de eventos e idéias, e a leitura freqüentemente oferece um maior alcance para o engajamento em histórias do que qualquer outra forma de atividade.

Assim, ao ler, o sujeito não só mantém seu "equilíbrio psíquico" como mobiliza e armazena uma gama de repertórios que obteve durante a sua vida em contato com os outros, ao mesmo tempo em que aumenta suas experiências e, então, a partir de suas leituras, é muito provável que passe a se relacionar com o mundo e agir de maneira diferenciada.

Desta forma, partindo do pressuposto de que a leitura é um ato individual, mas não solitário, uma vez que mobiliza todo o repertório daquele que lê, suas crenças e valores, ou seja, sua relação com o mundo e com as pessoas que o circundam, podemos pensar na leitura como produção social e socializadora ao mesmo tempo. De acordo com Eireter (2001), o modo como interpretamos o mundo, os estímulos que dele recebemos (sejam imediatos ou mediados por textos), a leitura que dele executamos é socialmente constituída e muda ao longo da história. Ao ler, travamos um diálogo com o autor, com a sociedade na qual este viveu e também com a sociedade em que vivemos.

No seu livro "Questões de literatura e estética", ao discutir a questão do discurso na literatura, Bakthin (1988, p.86) nos revela que o diálogo inerente aos diversos discursos, incluindo-se aqui o literário, faz-se, sobretudo, dentro de uma esfera social: 
O enunciado existente, surgindo de maneira significativa num determinado momento social e histórico, não pode deixar de tocar os milhares de fios dialógicos existentes, tecidos pela consciência ideológica em torno de um dado objeto de enunciação, não pode deixar de ser participante ativo do diálogo social. Ele também surge desse diálogo como seu prolongamento, como sua réplica (...)

Sendo "todas as palavras e formas que povoam uma linguagem vozes sociais" (1988, p.106), Bakhtin (1988, p. 100) conclui que

Em essência, para a consciência individual, a linguagem enquanto concreção sócio-ideológica viva e enquanto opinião plurilíngüe, coloca-se nos limites de seu território e nos limites do território de outrem.

Em “Sobre a literatura”, Marcel Proust, citando Descartes, afirma que a leitura é como uma conversação com as pessoas mais honestas dos séculos passados. Porém, Proust (1989, p.27 e 30) vai mais além: a leitura não termina na conversação, ela parte dela e continua, permitindo um desenvolvimento do pensamento que vai além daquele momento de comunicação:

(...) a leitura, ao contrário da conversação, consistindo para cada um de nós em receber a comunicação de um outro pensamento, mas permanecendo sozinho, isto é, continuando a desfrutar do poder intelectual que se tem na solidão e que a conversação dissipa imediatamente, continuando a poder ser inspirado, a permanecer em pleno trabalho fecundo do espírito sobre si mesmo.

\section{E complementa:}

Sentimos muito bem que nossa sabedoria começa onde a do autor termina, e gostaríamos que ele nos desse respostas, quando tudo o que ele pode fazer é dar-nos desejos. Estes desejos, ele não pode despertar em nós senão fazendo-nos contemplar a beleza suprema à qual o último esforço de sua arte lhe permitiu chegar. Mas por uma lei singular e, aliás, providencial da ótica dos espíritos (lei talvez que signifique que não podemos receber a verdade de ninguém e que devemos criá-la nós mesmos), o que é o fim de sua sabedoria não nos parece senão como começo da nossa, de sorte que é no momento em que eles nos disseram tudo que podiam nos dizer que fazem nascer em nós o sentimento de que ainda nada nos disseram.

Ao falar das metáforas de leitura, Manguel (2004, p.196) faz a seguinte observação sobre o poeta Walt Whitman:

Para Whitman, texto, autor, leitor e mundo espelhavam-se uns aos outros no ato da leitura, um ato cujo significado ele expandiu até que servisse para definir cada atividade humana vital, bem como no universo em que tudo acontecia. Nessa conjunção, o leitor reflete o escritor (ele e eu somos um), o 
mundo faz eco a um livro (livro de Deus, livro da Natureza), o livro é de carne e sangue (carne e sangue do escritor, que mediante uma transubstanciação literária se tornam meus), o mundo é um livro a ser decifrado (os poemas do escritor tornam-se minha leitura do mundo). Durante toda sua vida, Whitman parece ter buscado uma compreensão e uma definição do ato de ler, que é a um só tempo ele mesmo e a metáfora de todas as suas partes.

Podemos dizer que a leitura é para estes autores um diálogo social sem barreiras temporais que se desenvolveria em um diálogo interno reflexivo e leva ao desenvolvimento intelectual tanto individual como humanitário, na medida em que a sociedade é composta de homens e suas idéias.

Mais adiante veremos que a leitura é este diálogo entre leitor-autor mediado pelo texto, e para que haja compreensão é preciso, segundo Frank Smith (2003, pp.200-201), que o leitor tenha questões relevantes a fazer (que o texto pode responder) e que seja capaz de encontrar respostas, pelo menos, para algumas destas questões. Para o autor, "a leitura depende de relevância da especificação que o leitor faz ao texto", ou seja, da capacidade do leitor em travar um diálogo relevante com o autor e transformar sua leitura em uma prática social, relacionando-se com o autor e refletindo sobre diferentes questões relevantes para a sua humanidade.

Assim, ao ler e compreender/dialogar com o que lê, o homem torna-se letrado. O fenômeno deste letramento não possui apenas uma dimensão pessoal, mas possui também uma importante dimensão na sociedade, por ser uma prática social. Segundo Soares (2003, p.72),

Letramento é o que as pessoas fazem com as habilidades de leitura e de escrita, em um contexto específico, e como estas habilidades se relacionam com as necessidades, valores e práticas sociais. Em outras palavras, letramento não é pura e simplesmente um conjunto de habilidades individuais; é o conjunto de práticas sociais ligadas à leitura e à escrita em que os indivíduos se envolvem em seu contexto social.

Soares (2003, p. 75) aponta a existência, ainda, de alguns teóricos que consideram o letramento como:

(...) um conjunto de práticas socialmente construídas que envolvem a leitura e a escrita, geradas por processos sociais mais amplos, e responsáveis por reforçar ou questionar valores, tradições e formas de distribuição de poder presentes nos contextos sociais. 
Neste sentido, para Paulo Freire (2002, p. 112), ser alfabetizado é tornar-se capaz de usar a leitura e a escrita como um meio de tomar consciência da realidade e transformá-la.

Em síntese, a concepção de leitura que propomos aqui é este importante diálogo fundamental na humanização do homem e com um forte caráter social, exatamente por se constituir em um diálogo constante com o outro (épocas, lugares, realidades distintas ou não). Um diálogo que, segundo Freire (2002, pp. 98 e 116), deve nos predispor a constantes revisões, "a uma certa rebeldia, no sentido mais humano da expressão" e que é, sobretudo, uma relação horizontal:

(...) nasce de uma matriz crítica e gera criticidade (Jaspers). Nutre-se do amor, da humildade, da esperança, da fé, da confiança. Por isso, só o diálogo comunica. E quando os dois pólos do diálogo se ligam assim com amor, com esperança, com fé um no outro, se fazem críticos na busca de algo. Instalase, então, uma relação de simpatia entre ambos. Só aí há comunicação.

E, citando Jaspers, completa:

O diálogo é, portanto, o indispensável caminho não somente nas questões vitais para nossa ordenação política, mas em todos os sentidos do nosso ser. Somente pela virtude da crença, contudo, tem o diálogo estímulo e significação: pela crença no homem e nas suas possibilidades, pela crença de que somente chego a ser eu mesmo quando os demais também cheguem a ser eles mesmos.

Assim, Freire acredita que a educação democrática e o diálogo proporcionado pela educação (e aqui levamos esta reflexão também para o ato de ler) baseiam-se na crença no homem, "na crença em que ele não só pode, mas deve, discutir os seus problemas. Os problemas de seu país, do seu continente, do mundo” (Freire, 2002, p.104). 


\section{CAPÍTULO 3 - DESVELO E LEITURA: A CONSTRUÇÃO SOCIAL DO LEITOR}

Após refletirmos sobre a importância do ato de ler e suas conseqüências tanto individuais como sociais, buscamos neste capítulo discutir a importância das contribuições da Psicolingüística, voltadas para o ato de ler, em especial de textos informativos, e da Estética da Recepção, referentes aos textos literários. Isto porque ao focalizarem, sobretudo, o leitor dentro do processo de leitura, nos proporcionam ferramentas para que possamos auxiliar nossos alunos a se constituírem como leitores, partindo fundamentalmente do papel do prazer estético e afetivo neste processo.

\subsection{UM OLHAR SOBRE OS PROCESSOS ENVOLVIDOS NO ATO DE LER: CONTRIBUIÇÕES DA PSICOLINGÜÍSTICA}

$\mathrm{Na}$ tentativa de buscar respostas para alguns dos questionamentos acerca do processo de constituição de leitores e melhoria da qualidade de ensino, teóricos, dentre eles, Frank Smith, passaram a estudar o processo de leitura sob um prisma muito mais amplo, envolvendo diferentes aspectos cognitivos: o conhecimento prévio que cada leitor possui (conhecimento adquirido ao longo da vida), os objetivos e expectativas de leitura, estratégias de processamento do texto e a interação na leitura de textos (intertextualidade).

Para o ensino e aprendizagem, a principal contribuição desses estudos é provável que seja o fato de focalizar o processo de leitura principalmente no leitor, elemento da tríade autor-texto-leitor que pode ser melhor trabalhado e desenvolvido pelos educadores para tornar o processo de leitura significativo. Ao transformar o aluno em um leitor competente, este se tornaria apto a tecer relações necessárias para a construção de sentido e saber fazer uso eficiente de diferentes estratégias de leitura. Trata-se de uma questão de fundamental importância, sobretudo quando levamos em consideração que a aprendizagem da criança na escola está ancorada na leitura, como coloca Kleiman (2004, p. 7).

O papel do professor seria, então, criar oportunidades que permitissem o desenvolvimento do processo cognitivo da leitura de seus alunos, lembrando sempre que a leitura, além de um ato cognitivo, é também um ato social. Segundo Kleiman (2004, p. 7), um ato "entre dois sujeitos - autor e leitor - que interagem entre si, obedecendo a objetivos $e$ 
necessidades socialmente determinados". Essa dimensão interacional seria, para a autora, a mais importante do ato de ler. Ou, como coloca Jauss (2002, p. 83), em outras palavras,

a experiência estética não se distingue apenas do lado de sua produtividade (autor), como criação através da liberdade, mas também do lado de sua receptividade (leitor), como "aceitação em liberdade".

Segundo Smith (2003, p. 201), a compreensão de uma leitura depende dos leitores, das perguntas, expectativas e especificações que estes impõem ao texto. Assim, "o significado particular da leitura seria a resposta que o leitor obtém para determinada questão. O significado, portanto, também depende das questões que são formuladas". Smith (2003, p.202) ainda acrescenta:

Uma habilidade particular de escritores talentosos (e de professores talentosos) é levar os leitores a formularem as questões que consideram apropriadas. Assim a base da leitura fluente é a habilidade para encontrar respostas, na informação visual da linguagem escrita, para as questões particulares que estão sendo formuladas. A linguagem escrita faz sentido quando os leitores podem relacioná-la ao que já sabem (incluindo aquelas ocasiões quando o aprendizado ocorre, quando existe uma modificação global naquilo que os leitores já sabem). E a leitura é interessante e relevante quando pode ser relacionada ao que o leitor deseja saber.

Essa atividade comunicativa e interativa da leitura é a chave para melhor entendermos os processos envolvidos no ato de ler e os aspectos que devem ser trabalhados nos processos de ensino e aprendizagem, especialmente quando sabemos que essa atividade é mediadora da experiência estética (Jauss, 2002, p. 74), fundamental para a constituição do leitor, como veremos no próximo tópico.

Portanto, buscar compreender os aspectos cognitivos da leitura e os conceitos que estão subjacentes a esta faculdade, focalizando sempre o leitor, é fundamental para que o professor possa construir uma prática educacional mais consciente e estratégica ao pensar no processo de constituição de leitores.

Há fortes evidências de que um dos grandes problemas na maneira por meio da qual a leitura se dá em sala de aula é o fato de ela não apresentar um objetivo, como diz Kleiman (2004, p. 30), e de aparecer sempre desvinculada da questão do leitor. Pensamos e refletimos pouco sobre quem é o leitor que está na escola, quais são seus conhecimentos de mundo, 
quais seus conhecimentos prévios e, sobretudo, quais são seus horizontes de expectativas. Assim, sem levar em consideração estes leitores específicos não será possível criar oportunidades que permitam o desenvolvimento do processo cognitivo que é a leitura.

Além do conhecimento de mundo que os alunos trazem para a escola, os horizontes de expectativas também podem ser trabalhados em sala de aula pelos professores por meio de atividades relacionadas aos gêneros textuais e tipos de discurso, o que possibilitará preparar seus alunos para que estes possam criar suas expectativas em relação a um dado texto e desenvolverem suas próprias previsões sobre a leitura, o que, de acordo com Smith (2003, p. 211), facilitará a compreensão do texto e a reflexão do leitor:

\footnotetext{
A leitura fluente está baseada em uma especificação flexível de intenções e expectativas, que mudam e se desenvolvem como uma conseqüência da progressão do leitor ao longo do texto. Assim a leitura fluente demanda conhecimento das convenções do texto, de vocabulário e gramática a estratégias de narrativa empregadas. A quantidade de conhecimento convencional requerida depende das finalidades do leitor e da demanda da situação.
}

Nisto reside a importância do estudo de diferentes gêneros textuais na escola, segundo Smith (2003, p.209):

A vantagem de um leitor competente sobre um neófito reside na familiaridade com uma gama de diferentes espécies de textos, não na possessão de habilidades que facilitem cada tipo de leitura (...) Quanto mais lemos, mais somos capazes de ler.

O leitor fluente busca na leitura a satisfação de suas intenções, faz escolhas, antecipa conseqüências e extrai sentido das situações. Para que o leitor atinja esta fluência desejada, Smith (2003, p.227) afirma que há três elementos determinantes na aprendizagem:

Estes elementos podem ser chamados de demonstrações, que são condições para o aprendizado existentes em todos nós; engajamento, que é a interação do cérebro com a demonstração; e sensibilidade, o estado de aprendizado do cérebro.

Assim, para Smith, a "demonstração" é a oportunidade de observar o que e como pode ser feito. Pergunta-se então: que tipo de leitura os alunos vêem o professor fazer? O que os professores demonstram sobre o seu interesse na leitura? O "engajamento", por sua vez, 
remete à situação em que o aprendiz se engaja na demonstração e responde a uma nova informação. Por fim, a "sensibilidade" seria a ausência de qualquer expectativa de que o aprendizado não ocorra, ou de que será difícil.

\subsection{UM OLHAR SOBRE A LEITURA DO TEXTO LITERÁRIO: CONTRIBUIÇÕES DA ESTÉTICA DA RECEPÇÃO (REZEPTIONSÄSTHETIK)}

Se a Psicolingüística estuda aspectos concernentes ao ato de ler, uma outra vereda é iluminada pela Estética da Recepção. Neste trabalho, são considerados, sobretudo, os estudos de Hans Robert Jauss que têm como foco o leitor, assim como os estudos de Kleiman e Smith já apresentados.

Ao considerar a literatura enquanto produção-recepção-comunicação, tanto na Estética da Recepção como nas teorias Psicolingüísticas cabe ao leitor atribuir sentido ao texto, partindo de perguntas ou hipóteses (horizontes de expectativas) e fazendo uso de diferentes estratégias cognitivas: tanto o conhecimento lingüístico como o extra-lingüístico (valores e conhecimento de mundo) são fundamentais para a construção do sentido.

Considerando, assim, o papel fundamental do leitor no processo de leitura, Certeau (1996, p. 271) propõe que olhemos o ato de ler como um espaço de jogo, no qual o leitor, numa operação de caça, busca dar sentido ao texto.

Para Certeau (1998, p. 264-266), ao contrário dos que pensavam ser a leitura um ato passivo:

(...) ler é peregrinar por um sistema imposto (...) Análises recentes mostram que "toda leitura modifica o seu objeto", que (já dizia Borges) "uma literatura difere da outra menos pelo texto que pela maneira como é lida", e que enfim um sistema de signos verbais ou icônicos é uma reserva de formas que esperam do leitor o seu sentido. Se portanto "o livro é um efeito (uma construção) do leitor", deve-se considerar a operação deste último como uma espécie de lectio, produção própria do "leitor". Este não toma nem o lugar do autor nem um lugar de autor. Inventa nos textos outra coisa que não aquilo que era a "intenção" deles. Destaca-os de sua origem (perdida ou acessória). Combina os seus fragmentos e cria algo não-sabido no espaço organizado por sua capacidade de permitir uma pluralidade indefinida de significações. 
E completa que:

o texto só tem sentido graças a seus leitores; muda com eles; ordena-se conforme códigos de percepção que lhe escapam. Torna-se texto somente na relação à exterioridade do leitor, por um jogo de implicações e de astúcias entre duas espécies de "expectativas" combinadas: a que organiza um espaço legível (uma literalidade) e a que organiza uma démarche necessária para a efetuação da obra (uma leitura).

Pensando, então, nos nossos alunos como leitores e na relevância de seu papel na construção do sentido de um texto, é fundamental que se leve em consideração que estes querem encontrar na leitura um reflexo de suas angústias e também de seus prazeres, por isso faz-se necessário começar a levar em conta as características desses alunos no momento da escolha de livros, de indicações de leitura bem como da maneira pela qual esta será trabalhada. Se não transformarmos a leitura em uma atividade de prazer e de diálogo, dificilmente conseguiremos fazer com que nossos alunos possam futuramente experienciar criticamente o prazer estético de uma obra de arte.

Assim, sem um primeiro contato descompromissado, baseado no prazer da identificação, da catarse no sentido aristotélico da palavra, não se pode desenvolver a faculdade de ler. Aqui cabe lembrar a afirmação kantiana do prazer desinteressado próprio da arte, trabalhado por Jauss, e que mais tarde transformou-se, na teoria de Gêiser, no “desinteresse interessado" (Lima, 2002, p.22). Segundo Jauss (Lima, 2002, p. 22):

Na reação de prazer ante o objeto estético, realiza-se (...) uma reciprocidade entre sujeito e objeto, em que ganhamos interesse em nossa ausência de interesse.

Desta forma, o prazer de tornar o texto coerente, de significar, deveria ser o foco inicial de toda a atividade de leitura em sala de aula, para que, mais adiante, os alunos possam dar o grande passo em direção à busca do prazer estético que está no destrinchamento estrutural do texto, no entendimento e na valorização da construção de que resulta o texto bem escrito, seja ele de que natureza for. E é esta importância do prazer estético e da doutrina dos afetos que será tratada no próximo segmento deste texto. 


\subsubsection{O PAPEL DO AFETO (PRAZER EMOCIONAL) E DO PRAZER ESTÉTICO}

Dentro do escopo fornecido pela Estética da Recepção, gostaríamos, neste trabalho, de aprofundar um aspecto fundamental, que nos pareceu bastante relevante e que de certo modo julgamos estar conectado a todos os outros, servindo de ponto de partida para a aproximação do aluno com a leitura: o desenvolvimento do prazer estético e a importância do afeto / prazer emocional na constituição de leitores.

Se considerarmos, a princípio, que a leitura possui três dimensões: afetiva (como nos sentimos em relação ao que estamos lendo e ao próprio ato de ler), cognitiva (saber/ conhecimento) e pragmática (estratégias para interagir com o texto), pode-se concluir que todas estas dimensões estão envolvidas no que chamamos de prazer estético.

No entanto, para que o leitor consiga atingir o prazer estético e caminhar por estas três dimensões é preciso que, num primeiro momento, exista uma identificação do leitor ou com a história, ou com o tema, ou com uma ou outra personagem, o que desencadearia um prazer emocional ligado à dimensão afetiva. Ou seja, é necessário que a leitura propicie um momento de catarse aristotélica, segundo Jauss (2002, p. 86-87):

o espectador (no caso leitor) pode ser afetado pelo que se representa, identificar-se com as pessoas em ação, dar assim livre curso às próprias paixões despertadas e sentir-se aliviado por sua descarga prazerosa como se participasse de uma cura (katharsis).

Por isso, os contatos iniciais com a leitura, desde o nascimento, nas relações familiares, passando pela educação infantil e os anos iniciais do ensino fundamental, devem priorizar a dimensão afetiva e o pilar da "magia/estética", para que, então, a criança seja seduzida para o universo da leitura.

A leitura, quando pensamos no leitor iniciante, deveria, para Landeira (2005), penetrar no indivíduo de maneira a "atingir o secreto do homem tanto no que mostra aos outros, como naquilo que lhe é interior", o que só pode ser realizado por meio da dimensão afetiva. A afirmação que segue, de Jauss (2002, p. 69), também corrobora a afirmação de que a experiência emocional é fundamental para o desencadeamento do processo de leitura: 
A experiência estética não se inicia pela compreensão e interpretação do significado de uma obra; menos ainda, pela reconstrução da intenção de seu autor. A experiência primária de uma obra de arte realiza-se na sintonia com (Einstellung auf) seu efeito estético, isto é, na compreensão fruidora e na fruição compreensiva. Uma interpretação que ignorasse esta experiência estética primeira seria própria da presunção do filólogo que cultivasse o engano de supor que o texto fora feito, não para o leitor, mas sim especialmente, para ser interpretado.

Colocar o prazer estético como a orientação fundamentadora da experiência estética corresponde à própria concepção de leitura do presente trabalho, uma vez que acreditamos, como o autor, na correspondência da experiência estética com as outras áreas de significação da realidade cotidiana, e um dos valores da arte está nesse entrelaçamento da experiência humana.

Quando se pensa no leitor iniciante e em constituição de leitores, sejam eles crianças, jovens ou adultos, torna-se cada vez mais evidente que a aproximação inicial com a leitura ou com o próprio objeto-livro deve se fazer, primeiramente e, sobretudo, por meio do afeto e do prazer primário, oriundo do efeito estético de uma dada obra. A compreensão fruidora é o primeiro passo para seduzir o sujeito para o mundo das letras. Smith (2002, p. 225) nos explica que se a criança não consegue extrair sentido daquilo que se espera que ela aprenda, ela sente tédio e a falta de estímulo, aliada ao medo de cometer erros, torna-a relutante em aprender. Assim, não devemos buscar logo de início transformar o prazer da leitura em uma complexa trama de interpretações, com o risco de criarmos bloqueios que impedirão o desenvolvimento da prática da leitura.

Evidentemente, a reflexão, a busca de interpretação e a reconstrução dos sentidos são essenciais no processo de leitura, porém, não devemos considerar esta postura racional e crítica mais importante do que o prazer da experiência humana primeira que ocorre por meio da comunicação. Nem devemos esperar esta postura de nós e dos leitores iniciantes o tempo todo.

Com isso, Jauss (2002, p. 95) não quis dizer que o prazer estético se limite a este primeiro contato com a obra de arte. Ele afirmou que este prazer libera da obrigação prática do trabalho, porém, não se opõe ao conhecimento nem à ação. 
O prazer estético exige também um momento crítico que exclui a existência do objeto e o transforma em objeto estético: assim o sujeito participa da produção da obra de arte e dela se apropria, de acordo com seu nível de identificação e sua biografia particular.

Esta apropriação e co-produção do objeto de arte (atividade reflexiva e crítica) só podem ser desenvolvidas pelo sujeito depois que este teve seus sentimentos evocados, liberando-se da existência cotidiana por meio do prazer. Parece-nos, aqui, bastante relevante a afirmação de Jauss (2002, p. 96) de que “a comunicação literária só conserva o caráter de uma experiência estética enquanto a atividade da poiesis, da aisthesis ou da katharsis mantiver o caráter de prazer".

Aqui lembramos que a mediação de um adulto (professor) faz-se fundamental para que o aluno aprimore suas habilidades de leitura e torne-se um leitor competente, capaz de fazer esta passagem da experiência primária ao ato de reflexão, sobretudo quando o professor busca fazer com que o aluno compreenda como a obra se estrutura e quais os recursos estéticos e lingüísticos que causam o prazer. A própria palavra "prazer”, em alemão, possui o sentido de "participação e apropriação" (Jauss, 2002, p. 85), lembrando mais uma vez do papel do leitor na construção do seu próprio prazer. O ato da reflexão que deve seguir-se ao prazer emocional para se constituir em um prazer estético, transformando os textos lidos em espaço de interação é fundamental, tendo em vista a constituição de leitores críticos, como explica Jauss (2002, p. 96 e 98) em duas passagens:

Enquanto o eu se satisfaz no prazer elementar, e este, enquanto dura, é auto-suficiente e sem relação com a vida restante, o prazer estético exige um momento adicional, ou seja, uma tomada de posição, que exclui a existência do objeto e, deste modo, o converte em objeto estético.(...) Em face disso, a atitude estética exige que o objeto distanciado não seja contemplado desinteressadamente, mas que seja co-produzido pelo fruidor (...)

$\mathrm{E}$

O interesse estético se explica pelo fato de que o sujeito, enquanto utiliza sua liberdade de tomada de posição perante o objeto estético irreal, é capaz de gozar tanto o objeto, cada vez mais explorado por seu próprio prazer, quanto seu próprio eu, que nesta atividade, se sente liberado de sua existência cotidiana. Por conseguinte, o prazer estético realiza-se sempre na relação dialética do prazer de si no 
prazer do outro. (...) Isso pressupõe a unidade primária do prazer cognoscente e da compreensão prazerosa, restituindo o significado, originalmente próprio ao uso alemão, de participação e apropriação. Na conduta estética, o sujeito sempre goza mais do que si mesmo: experimenta-se na apropriação de uma experiência do sentido do mundo, ao qual explora tanto por sua própria atividade produtora, quanto pela integração da experiência alheia e que, ademais, é passível de ser confirmado pela anuência de terceiros. O prazer estético que, desta forma, se realiza na oscilação entre a contemplação desinteressada e a participação experimentadora, é um modo da experiência de si mesmo na capacidade de ser outro, capacidade a nós aberta pelo comportamento estético.

\subsubsection{CONSTRUÇÃO SOCIAL DO LEITOR CRÍTICO POR MEIO DE PRAZER ESTÉTICO E EMOCIONAL: O JOVEM LEITOR E SEU HORIZONTE DE EXPECTATIVAS}

Tendo em mente que é preciso constituir leitores, perguntamos-nos: quem são estes leitores que queremos constituir? Que jovens são estes que estão nas escolas e formam o público atendido também pelas ONGs aqui em questão? Qual a sua relação com a literatura? Em relação à leitura, quais são seus horizontes de expectativas? Como a leitura pode ser prazerosa?

De acordo com Brasília (2005), as escolhas de leitura que os jovens possuem fora da escola constituem-se no que chamam de escolhas anárquicas, pois, segundo as autoras, os jovens tendem a escolher suas leituras de maneira aleatória, tendo como critérios aspectos como o título, a capa, o número de páginas e indicações de amigos. Quer dizer, deixam-se levar por seus desejos imediatos e mantêm-se longe do cânone literário.

Entendemos que não devem ser desconsideradas estas "escolhas anárquicas" de leitura, que também possuem sua importância, por serem escolhas livres e, portanto, mais ligadas à leitura como gosto e ao prazer emocional que discutimos anteriormente. Porém, tendo em vista que esta se dá de forma aleatória, a escola e as ONGs devem sistematizar a leitura e buscar ordená-la, baseando-se, sobretudo, no valor estético das obras a serem trabalhadas e nos assuntos pertinentes aos horizontes de expectativas dos jovens leitores. Assim, serão criadas condições para um contato dos jovens com leituras que, muito provavelmente, não fariam se fossem deixados à deriva no meio de suas "escolhas anárquicas”. No seu livro “A aventura do livro - do leitor ao navegador”, Roger Chartier 
(1999, p. 103-4) responde se concorda com a idéia segundo a qual as classes mais jovens estão se afastando da leitura:

Sim, se concordarmos implicitamente sobre o que deve ser a leitura. Aqueles que são considerados nãoleitores lêem, mas lêem coisa diferente daquilo que o cânone escolar define como uma leitura legítima. O problema não é tanto de considerar como não-leituras estas leituras selvagens que se ligam a objetos escritos de fraca legitimidade cultural, mas é o de tentar apoiar-se sobre essas práticas incontroladas e disseminadas para conduzir esses leitores pela escola mas também sem dúvida por múltiplas outras vias, a encontrar outras leituras. É preciso utilizar aquilo que a norma escolar rejeita como um suporte para dar acesso à leitura na sua plenitude, isto é, ao encontro de textos densos e mais capazes de transformar a visão do mundo, as maneiras de sentir e de pensar.

Assim, as escolhas dos textos a serem trabalhados, feitas pelas escolas e pelas ONGs, precisam levar em consideração o valor estético das obras, mas também o público com o qual estão lidando: o jovem leitor.

Se pensarmos no texto como o ponto de partida e o ponto de chegada, repleto de indicações de leitura, e possuindo a dimensão dialógica que Bakhtin (1988) explicita, talvez possamos descobrir como as leituras literárias podem tornar-se significativas para os jovens brasileiros. A estética da recepção e a teoria dos gêneros talvez possam auxiliar-nos, mais uma vez, nesta questão.

Estabelecer o contato dos jovens com os mais diversos tipos de gêneros literários é importante para que se constituam como leitores, na medida em que, segundo Jauss (1994), ao conhecerem os elementos de permanência de determinados gêneros, podem criar um horizonte de expectativas e um saber literário prévio. Assim, os jovens podem familiarizar-se com o texto e prepararem-se para recebê-los com uma postura mais crítica.

Segundo Bakhtin (1988), ao tratarmos com diferentes gêneros, dialogamos com diferentes aspectos da sociedade, e herdamos o legado cultural da humanidade. O diálogo entre o texto, outros textos e o leitor é fundamental para se gerarem opiniões.

Criar uma familiaridade com a literatura por meio do estudo dos gêneros ajuda a refinar a sensibilidade estética e o senso crítico. Segundo Brasília (2005), ao conhecer a tradição literária, oferecem-se instrumentos para uma penetração mais aguda nas obras. E 
completam que os gêneros literários devem ser considerados "como base para a didática da literatura na escola e podem contribuir para o planejamento de atividades de reorientação de leitura".

A constituição de um horizonte de expectativas, de acordo com Jauss (1994), não se dá somente por um leitor individual e sim pelo coletivo / social. O horizonte de expectativas (criado pela repetição de elementos dentro de um gênero) é elemento fundamental, juntamente com o leitor implícito no texto, para se buscar entender qual a intenção do texto, o resultado desta intenção e seu caráter artístico.

Ou seja, quando o jovem se constitui como leitor e constrói seus horizontes de expectativas no contexto social em que se insere, poderá perceber mais claramente a distância entre seu horizonte e o efeito final da obra, caracterizando, assim, a importância estética de um texto. $\mathrm{O}$ estranhamento, o choque gerado pelo distanciamento entre expectativas e efeito pode se dar de maneira positiva, trazendo um horizonte novo.

Talvez buscar desenvolver horizontes de expectativas e o conhecimento dos gêneros literários nos jovens possa auxiliá-los no seu contato como a literatura. Dialogar com os jovens, ouvindo o que pensam, o que sentem, o que esperam, na tentativa de desenvolver sua sensibilidade, expondo, em contrapartida, elementos novos que a literatura traz consigo para o diálogo, talvez ajude a melhorar o relacionamento entre nossos jovens e a literatura. $\mathrm{Na}$ escolha de textos para os jovens leitores é importante ter isso em mente, bem como o universo cultural e os estágios cognitivos dos alunos.

Segundo Nelly Novaes Coelho (2002, p. 32),

Para que o convívio do leitor com a literatura resulte efetivo, nessa aventura espiritual que é a leitura, muitos fatores estão em jogo. Entre os mais importantes está a necessária adequação dos textos às diversas etapas do desenvolvimento infantil/juvenil. Embora a evolução biopsíquica das crianças, préadolescentes e adolescentes divirja de uns para outros (...) a natureza e a seqüência de cada estágio são iguais para todos, conforme o prova a psicologia experimental. Assim, a inclusão do leitor em determinada "categoria" depende não apenas de sua faixa etária, mas principalmente da inter-relação entre sua idade cronológica, nível de amadurecimento biopsíquico-afetivo-intelectual e grau ou nível de conhecimento/domínio do mecanismo da leitura. 
Tendo em vista esta afirmação, a autora (2002, p. 33 a 40) sugere a seguinte classificação:

\section{- O Pré-Leitor:}

* Primeira infância (15/17 meses aos 3 anos): a criança inicia o reconhecimento da realidade, principalmente pelos contatos afetivos e pelo tato. É o momento em que a criança começa a conquista da própria linguagem e passa a nomear as realidades à sua volta.

* Segunda infância (a partir dos 2/3 anos): passagem da indiferenciação psíquica para a percepção do próprio ser. Início da fase egocêntrica e dos interesses ludopráticos. Impulso crescente de adaptação ao meio físico e crescente interesse pela comunicação verbal.

- O Leitor Iniciante (a partir dos 6/7 anos): Fase da aprendizagem da leitura, na qual a criança já reconhece, com facilidade, os signos do alfabeto e reconhece a formação das sílabas simples e complexas. Início do processo de socialização e de racionalização da realidade.

O Leitor-em-processo (a partir dos 8/9 anos): Fase em que a criança já domina com facilidade o mecanismo da leitura. Agudiza-se o interesse pelo conhecimento das coisas. Seu pensamento lógico organiza-se em formas concretas que permitem as operações mentais. Atração pelos desafios e pelos questionamentos de toda natureza.

O Leitor Fluente (a partir dos 10/11 anos): Fase de consolidação do domínio do mecanismo da leitura e da compreensão do mundo expresso no livro. A leitura segue apoiada pela reflexão; a capacidade de concentração aumenta, permitindo o engajamento do leitor na experiência narrada e, conseqüentemente, alargando ou aprofundando seu conhecimento ou percepção de mundo. A partir dessa fase, desenvolve-se o pensamento hipotético dedutivo e a conseqüente capacidade de abstração. O ser é atraído pelo confronto de idéias e ideais e seus possíveis valores ou desvalores. As potencialidades afetivas se mesclam com uma 
nova sensação de poder interior: a da inteligência, do pensamento formal, reflexivo. É a fase da pré-adolescência.

E, finalmente, o leitor crítico, alvo deste trabalho:

- O Leitor Crítico (a partir dos 12/13 anos): Fase de total domínio da leitura, da linguagem escrita, capacidade de reflexão em maior profundidade, podendo ir mais fundo no texto e atingir a visão de mundo ali presente. Fase de desenvolvimento do pensamento reflexivo e crítico, empenhado na leitura do mundo, e despertar da consciência crítica em relação às realidades consagradas. (...) Nesta fase, o adolescente deve se abrir plenamente para o mundo e entrar em relação essencial com o outro. (...) O convívio do leitor crítico com o texto literário deve extrapolar a mera fruição de prazer ou emoção e deve provocá-lo para penetrar no mecanismo de leitura. O conhecimento de rudimentos básicos de teoria literária faz-se necessário; pois a literatura é a arte da linguagem e como qualquer arte exige iniciação (grifo nosso).

Assim, tal classificação torna-se interessante no sentido de auxiliar professores e educadores a melhor adequar as propostas de leitura feitas a seus alunos, levando sempre em consideração seus respectivos momentos cognitivos, bem como seus horizontes de expectativas e interesses particulares. 


\section{Capítulo 4 - AS ONGs NA SOCIEDADE: EM FOCO, A LEITURA}

$\mathrm{Na}$ tentativa de buscar uma nova forma de trabalhar a leitura, privilegiando o prazer, setores da sociedade civil começaram a se mobilizar, sobretudo a partir dos anos 1990, instituindo espaços para discussão sobre a questão da leitura. Nesses locais ocorreram experiências diversas com o intuito de encontrar soluções para auxiliar jovens e crianças brasileiras a melhorar seu grau de letramento.

Segundo Soares (2003, p. 20-21), não basta "saber ler e escrever, é preciso saber utilizar tais capacidades a partir das exigências que a sociedade nos faz continuamente”, ou seja, "passar da mera aquisição da 'tecnologia' do ler e escrever à inserção nas práticas sociais de leitura e escrita”.

Por esse motivo, muitas ONGs possuem como meta "desinstitucionalizar" a leitura, trazendo-a também para fora da escola, para outros espaços sociais. O objetivo, entretanto, é caminhar junto à escola para transformar a leitura efetivamente em uma prática social. A sociedade como um todo pode assumir, assim, o seu papel na constituição de leitores, uma vez que, como explicitado anteriormente, a responsabilidade por esta constituição não pode ser creditada somente aos professores. Segundo Foucambert (1994), o poder de se formar leitores está para além dos muros da escola, e, conseqüentemente, a responsabilidade social de se criar diferentes espaços sociais da leitura.

Quando se discute a questão das ONGs e dos inúmeros projetos educacionais criados pela sociedade civil, faz-se necessário também o estabelecimento dos conceitos de educação formal e não-formal. Conceitos esses discutidos por Macedo \& Semeghini-Siqueira (2000, p. 4-5):

Pode-se considerar, portanto, como EDUCAÇÃO FORMAL todas as atividades proporcionadas pela escola e EDUCAÇÃO NÃO-FORMAL tudo que possa ocorrer independentemente das propostas dos professores. Há, seguramente, especificidade nas intervenções pedagógicas, que privilegiam o “aprender a aprender”, alavancadas pelo projeto político-pedagógico de cada escola, construído em função da diversidade dos educandos. É preciso, entretanto, abrir espaço para a articulação entre a educação formal e não-formal. $\mathrm{Na}$ atual sociedade do conhecimento, especialmente em um país em desenvolvimento, os problemas educacionais não serão resolvidos somente na sala de aula. 
Por sua vez, vale lembrar Brustein (2003, p. 43), para quem os interesses coletivos não podem ser objeto apenas do poder público, “muitas vezes distantes dos problemas locais, específicos e multifacetados". Isto permite que a sociedade como um todo busque intervir junto aos problemas vivenciados na realidade local. Devemos considerar que nossa sociedade tornou-se mais complexa, de maneira que a forma e função tradicionais da educação se tornaram insuficientes, podendo ser questionada a posição da escola no seu papel de educadora social. Isto quer dizer que ela tem se limitado a cumprir uma escolarização institucionalizada e de baixa qualidade, apresentando aos alunos poucas oportunidades de desenvolverem-se em outras áreas da existência humana.

Portanto, no presente capítulo, discutimos a importância da educação não-formal na constituição de leitores, a partir do papel das ONGs na transformação e melhoria da sociedade, procurando, desta forma, expor a relevância de sua atuação na área da educação.

\subsection{O PAPEL DAS ONGs NA TRANSFORMAÇÃO DA SOCIEDADE}

Ao falarmos das ONGs, é fundamental que possamos discutir seu papel na transformação da sociedade. Elas representam uma das diversas possibilidades de a sociedade buscar avanços em diferentes setores, tendo sido mais evidentes suas intervenções no campo ambiental e educacional.

A crise do marxismo desfocou as lutas da classe trabalhadora industrial. As análises mais consistentes e freqüentes versavam sobre as estruturas sociais e políticas do capitalismo que estavam na base dessas lutas. A ênfase atual, no entanto, está na análise da pluralidade dos conflitos na sociedade atual e nas novas formas de dominação, enfatizando o poder da produção cultural (Touraine, 1989) e das formas de violência/opressão simbólicas (Bourdieu, 1989). Com isso não afirmamos, todavia, que as classes sociais e suas contradições tenham deixado de existir, mas sim que, a partir da pós-modernidade, o foco das análises mudou.

Esperamos concretizar, na presente dissertação, a análise de Cristian Topalov (1988, p.22-23): as grandes análises estruturais feitas pelos estudos marxistas deixaram de ser 
centrais e mesmo tornaram-se secundárias, e, concomitantemente, deu-se “(...) a reabilitação do empirismo, da descrição sem fim das singularidades (...)" resultante do exame crítico das anteriores análises globais. Topalov nos alerta de que é imperativo contemporaneamente buscar uma maneira de dar sentido a essas situações singulares e, assim, ultrapassarmos as limitações tanto desta abordagem como da anterior.

Nesta nova sociedade, as ONGs, dentro de uma conjuntura política favorável, possuem um papel importante como geradoras de transformações. Ao intervir diretamente nessa conjuntura, buscam a ampliação de direitos e a conquista de benefícios sociais, culturais e materiais. Aproveitamos este momento para diferenciarmos as ONGs dos movimentos sociais. Embora ambos sejam formas de organização da sociedade civil que buscam a ampliação de direitos e a conquista de benefícios, e suas origens (a forma como a coletividade se organiza na sociedade contemporânea) possam ser explicadas pelas teorias que analisamos adiante, eles possuem naturezas completamente diferentes. Enquanto as ONGs podem ser consideradas iniciativas privadas com fins públicos, mas que preservam sua dimensão privada e falam em nome de si mesmas, os movimentos sociais, como o MST Movimento dos Sem-Terra - possuem um alcance muito mais amplo e representam um segmento social, nem sempre possuindo uma forma institucional.

A seguir, a partir das análises e interpretações de Alain Touraine (1981) e Alberto Melluci (1989), discutimos o quadro sociológico em que se encontram as ONGs, a sua importância e a forma como estas podem contribuir para a transformação da sociedade.

Assim, refletimos sobre as mudanças produzidas pelas ONGs no cotidiano da sociedade e as possibilidades originadas de suas lutas no tocante ao fortalecimento da democracia e da liberdade.

Como afirma Gadotti (apud Camba, 1993, p. 113):

qualquer mudança significativa e duradoura será resultado do esforço coletivo (...) o que faz com que um governo seja mais participativo são as lutas e pressões da sociedade. 


\subsection{AS ONGs E A ATUAL SOCIEDADE COMPLEXA}

Se, anteriormente, os conflitos geradores de movimentos sociais estruturavam-se sobre o modo de produção (lutas de classe), agora nos encontramos diante da teoria da produção social. Tal teoria defende que as novas maneiras de expressão social (incluindo as ONGs) surgiram em espaços abertos pela nova sociedade advinda do processo de globalização, na qual as relações sociais, os processos naturais do homem em significar, a informação e a ciência possuem papéis centralizadores. É a luta pelos meios de produção cultural, incluindo-se a educação, que está em foco em nosso trabalho.

O ápice do capitalismo na globalização pôs em evidência a sociedade complexa. Essa sociedade engloba alguns conceitos que ajudam a explicar a realidade dada, tais como: a crise do marxismo e dos paradigmas, a multiplicidade dos atores e conflitos, a contaminação da esfera pública com a privada em muitos aspectos da vida cotidiana, e, por fim, o sistema de redes de relacionamentos e o controle da informação.

Assim, com a secundarização (e não o fim) da era do industrialismo e da tradicional luta entre operários (proletariado) e patrões, as análises dos conflitos não são mais centradas na questão da produção, agora são múltiplas, descentralizadas, plurais e difusas. Melluci (2000) denominou de nômade a busca de novas necessidades como preocupação social. São tão plurais quanto são as influências, os controles e os poderes simbólicos aos quais a sociedade está submetida. De acordo com Melluci (2001, p. 9):

(...) os sistemas complexos exigem formas de poder e de controle que asseguram a sua integração e devem avançar até o nível mais íntimo no qual se forma o sentido do agir individual e coletivo. Não é suficiente controlar a ação manifesta, mas interferir nas suas raízes motivacionais, cognitivas, afetivas; é preciso manipular a estrutura profunda da personalidade e da própria estrutura biológica.

Marx (2002) já dizia que, para sua reprodução social, não basta o capitalismo estabelecer as relações sociais de produção econômica. É fundamental que o capitalismo produza um pensamento entre as pessoas das regras de como ele funciona, sua aceitação e submissão nos mecanismos que hoje denominamos simbólicos. 
Por este motivo, a luta, segundo Touraine (1981, p. 34-35), encontra-se agora no campo do domínio da reprodução cultural, incluindo, especialmente, a educação. $\mathrm{O}$ reconhecimento do conflito na sua diversidade e heterogeneidade é básico para o entendimento das novas formas de organização social.

$\mathrm{Na}$ sociedade complexa, portanto, emerge o conflito no campo do simbólico. O objetivo é debater, buscar melhorias, nem sempre se propondo a atingir, hoje, uma grande mudança estrutural.

A sociedade está estruturada em um sistema de redes de relacionamento, de acordo com os interesses próprios de cada setor social, e em um fluxo de informações. Em momentos de tensão, o setor social interessado deixa aflorar muitas destas redes, originando uma nova forma de emergência das lutas sociais que alternam momentos de latência e visibilidade. Para Melluci (2001, p.28), mais do que a abordagem das estruturas, a importância está em focalizar a vida cotidiana no seu aspecto micro, pois esta gera uma grande transformação da cultura e dos valores sociais.

Para Scherer-Warren (1995, p. 168), “a transformação social é concebida a partir das mudanças que ocorrem nas bases, nas relações micro, no cotidiano (...)". É a rede de relacionamentos do cotidiano que pode transformar e ampliar as práticas isoladas. Ou seja, são pequenas ações que acabam gerando grandes mudanças - realizações pontuais que podem, na medida em que o tempo passa, tomar dimensões nacionais e / ou internacionais.

\subsubsection{ONGs - Organizações não-governamentais}

As ONGs pertencem ao campo das novas possibilidades mencionadas nas considerações anteriores. Entretanto, analisá-las requer a cautela de verificar suas contradições e heterogeneidade. Dentro do vasto campo composto por essas organizações, há aquelas que se institucionalizam em moldes "empresariais", reproduzindo socialmente a ética capitalista e transformando-se em um empreendimento lucrativo, em que a questão social é secundária, ou apenas uma justificativa para suas existências. 
Contraditoriamente, há também entidades com objetivos e ideais não da "razão prática" ou "razão instrumental", para as quais o que importa não é a obtenção das beneces de uma inserção institucional. São constituídas por pessoas com razões éticas e filosóficas voltadas para posições humanistas. Ao se proporem a desenvolver ações voltadas para o campo social, não significa que seus objetivos e ideais tenham sempre muita clareza quanto aos resultados e implicações decorrentes, as quais podemos mesmo contestar ou questionar em alguns casos. Por outro lado, há aquelas ONGs cujos propósitos e fundamentos dificilmente podemos desprezar, pois ao nosso ver contemplam de maneira lúcida as necessidades de vários setores sociais.

Ao trabalhar no campo educacional, as ONGs deste último grupo partem da análise de Melluci - início em ações pontuais para buscar interferir no sistema de ensino no Brasil sobretudo quando se tem a premissa básica de Paulo Freire de que educação e conscientização jamais se separam, ou seja, de que todo aprendizado deve encontrar-se intimamente associado à tomada de consciência da situação real vivida pelo educando, ou melhor, nas palavras de Freire (2002, p. 52):

quando alguém diz que a educação é afirmação de liberdade se obriga, neste mesmo momento, a reconhecer o fato da opressão, do mesmo modo que a luta pela libertação (...) O homem seria livre para atuar segundo sua própria vontade, se soubesse o que quer, o que pensa e sente. Mas não sabe. Ajusta-se ao mandado de autoridades anônimas e adota um eu que não lhe pertence.

O próprio Melluci (2001, p. 22) afirma também que:

uma consciência acrescida das possibilidades e dos vínculos da ação pode transformar a palavra dos movimentos em linguagem, cultura, relações sociais e pode fazer dos processos coletivos uma prática de liberdade.

Assim, torna-se fundamental para as ONGs que consideramos educativas uma educação para a decisão, para a responsabilidade social e política, na qual exista o reconhecimento da consciência histórica (colocando o educando numa postura de autoreflexão e de reflexão sobre seu tempo e espaço), que forme cidadãos politicamente ativos ou, pelo menos, politicamente disponíveis para a participação democrática. 
A questão da luta pelo poder das produções culturais proposta por Touraine (1981, p. 34-35) aparece também nos escritos de Paulo Freire quando este enfatiza a importância de fazer com que os educandos, antes de começarem o aprendizado do que quer que seja, percebam primeiramente que são também, não importando sua origem social, criadores de cultura, que não estão somente submersos na cultura, mas que a possuem e a controlam. Muda-se, assim, sua postura diante do mundo, ampliando sua participação democrática e ajudando-os a fortalecer uma política popular, pois esta conscientização significa uma abertura à compreensão das estruturas sociais, dos modos de dominação e da violência. Freire (2002, p. 51) coloca, então, que é:

a partir das relações do homem com a realidade, resultantes de estar com ela e de estar nela, pelos atos de criação, recriação e decisão, vai ele dinamizando o seu mundo. Vai dominando a realidade. Vai humanizando-a. Vai acrescentando a ela algo de que ele mesmo é o fazedor. Vai temporalizando os espaços geográficos. Faz cultura. E é ainda o jogo destas relações do homem com o mundo e do homem com os homens, desafiando e respondendo ao desafio, alterando, criando, que não permite a imobilidade nem das sociedades nem das culturas.

O autor (2002, p. 42) acrescenta que:

herdando a experiência adquirida, criando e recriando, integrando-se às condições de seu contexto, respondendo a seus desafios, objetivando-se a si próprio, discernindo, transcendendo, lança-se o homem num domínio que lhe é exclusivo - o da História e o da Cultura.

Há muitos estudiosos defensores das ONGs voltadas para o atendimento das necessidades sociais. Assim, vemos análises bastante positivas das mesmas.

É o caso das análises a respeito da tendência à institucionalização dos movimentos sociais. Com vistas a uma maior profissionalização, eficácia nos resultados, captação e otimização de recursos materiais e humanos, resultaram as chamadas Organizações NãoGovernamentais (ONGs), que constituiriam uma forma de apoio e assessoria aos movimentos sociais. Para Scherer-Warren (1995, p. 162), são grupos com “alguma organização formal que atuam tendo em vista a transformação de aspectos da realidade social considerados como negativos".

De acordo com Camba (2004, p. 16-17), 
A denominação ONG foi criada pela Organização das Nações Unidas (ONU), na década de 40, para diferenciá-la dos órgãos governamentais. Porém, nem tudo que não é governo são ONGs. As ONGs são associações civis e autônomas, não-estatais, sem fins lucrativos e em sua maioria são suprapartidárias. Afirmam seus objetivos sociais e seu campo de atuação na Sociedade Civil. (...) As ONGs são organizações que objetivam não apenas a satisfação das necessidades e interesses de determinados grupos da sociedade, mas também e, especialmente, mudanças globais através da influência política (atuam no intuito de influenciar políticas públicas). As ONGs possuem tanto uma função social como uma função política. No Brasil, essa função política passou a destacar-se mais na década de 80, a partir da abertura democrática, quando foram criados mais espaços à participação da sociedade (...) Nos anos 90, o movimento ambientalista foi o grande responsável pela nova organização das ONGs no Brasil, a partir da ECO 92.

\section{Assim, pode-se concluir que}

as ONGs são como organizações formais, privadas, porém com fins públicos, sem fins lucrativos, autogovernadas e com participação de parte de seus membros como voluntários, objetivando realizar mediações de caráter educacional, político, assessoria técnica, prestação de serviços e apoio material e logístico para populações-alvo específicas ou para segmentos da sociedade civil, tendo em vista expandir o poder de participação destas com o objetivo último de desencadear transformações sociais no nível micro (do cotidiano e/ ou local) ou nível macro (sistêmico e/ou global).

Segundo Scherer-Warren (1995, p. 169), as ONGs prevêem que a expansão da democracia dar-se-á a partir da organização da sociedade civil, que poderá ocorrer nas múltiplas esferas do social. Esta expansão de uma democracia popular tem como contrapartida a diminuição e descentralização do poder do Estado. A autora (1995, p. 175176) ainda complementa que o importante é a possibilidade de as ONGs participarem de um movimento social sob a forma de rede:

Isto é, sem abdicar de seu papel histórico - como o comprometimento com a democratização e o direito de cidadania para todos; compromisso com os setores populares, em suas lutas contra a exclusão, desigualdade e discriminação étnica, de gênero e outras -, a ONG por meio de um novo princípio do pluralismo possível e da diversidade desejável, conjuga-se a outras forças sociais (setores das próprias agências, segmentos dentro do Estado, novas ONGs, organizações populares e lideranças formais e informais) na construção de um movimento social mais amplo, que possa visar transformações no âmbito local, regional, nacional e às vezes transnacional. 
Para Gohn (1997, p. 61), as ONGs são, portanto, mais um ator dentro do conjunto da sociedade civil e possuem o importante papel de lutar por um mundo mais igualitário e de se apresentarem como um novo espaço menos burocrático, constituindo "mecanismos fundamentais de construção da cidadania brasileira, podendo atuar como agentes de fiscalização da sociedade civil sobre a sociedade política, no gerenciamento de bens públicos."

Camba $(2004$, p. 38, 68) lembra oportunamente ainda que

As ONGs deveriam buscar acompanhar criticamente as políticas do governo, questionar as ações do Estado, apontar falhas, propor novos modelos de gestão pública e reivindicar a participação na elaboração das políticas públicas. É nesse sentido que se mostram ameaçadoras, pois ao pôr em prática projetos sociais inovadores, podem provar que é possível administrar melhor os problemas sociais enfrentados pela população. (...) A natureza das ONGs não é substituir a ação do poder público, do Estado. Seus serviços não são universais; elas não têm como proposta ter representatividade pública. Sua missão é identificar e analisar as causas dos problemas sociais, apontar soluções, construindo modelos de intervenção, ajudar a envolver a população na luta cidadã.

De todas essas análises podemos concluir que, se antes as ONGs faziam oposição ao Estado, hoje elas buscam sua parceria com o intuito de melhorar e assegurar os direitos sociais. Resta-nos verificar até que ponto, nessa parceria, elas sustentam sua autonomia e os ideais alardeados.

É preciso acrescentar, para a compreensão das ONGs e a temática educacional que, dentre os programas inscritos no prêmio Itaú-Unicef de 1999, 93\% disseram atuar na área de educação. São também importantes as informações coletadas na revista Veja (edição 1963, ano 39, no. 26 de 5 de julho de 2006), a respeito dos grandes doadores brasileiros às ONGs e projetos sociais: 


\begin{tabular}{|c|c|c|}
\hline NOME DO DOADOR & $\begin{array}{l}\text { QUANTO DOOU }(\mathrm{em} \\
\text { milhões de reais) }\end{array}$ & FOCO \\
\hline Fundação Bradesco & 157,6 em 2005 & Educação. \\
\hline Fundação Banco do Brasil & $105,8 \mathrm{em} 2005$ & $\begin{array}{l}\text { Educação, Tecnologia } \mathrm{e} \\
\text { geração de trabalho } \mathrm{e} \\
\text { renda. }\end{array}$ \\
\hline Petrobrás & 177 em 2005 & $\begin{array}{l}\text { Educação, cultura e } \\
\text { esporte. }\end{array}$ \\
\hline Instituto Ayrton Senna & 19 em 2005 & Educação. \\
\hline Fundação Victor Civita & 24 em 2005 & Educação. \\
\hline Fundação Itaú Social & 21,5 em 2005 & Educação e saúde pública. \\
\hline Fundação Orsa & 16,3 em 2004 & $\begin{array}{l}\text { Educação, saúde e } \\
\text { combate à violência. }\end{array}$ \\
\hline Instituto Gerdal & 41,7 em 2005 & Educação. \\
\hline Instituto Votorantim & 34 em 2005 & Educação e saúde. \\
\hline Fundação Belgo Mineira & 34,8 em 5 anos & Educação e saúde. \\
\hline Instituto C\&A & 8 em 2005 & Educação. \\
\hline Instituto Camargo Corrêa & 21,4 em 5 anos & Educação e saúde. \\
\hline
\end{tabular}

Figura 01 - Quadro de doações a ONGs segundo a revista Veja, em Julho de 2006.

Tendo em vista esta tabela, que inclui Institutos e Fundações, gostaríamos de enfatizar a heterogeneidade daquilo que comumente chamamos de ONGs, tendo a consciência da problemática que é a generalização de diferentes organizações sociais. Como, sob esta denominação genérica, há uma grande heterogeneidade de perfis, estas podem ser categorizadas das mais diferentes maneiras: regional, local, nacional, internacional, de defesa dos direitos humanos, ecológicas, alinhada às igrejas ou não etc.

Em geral, as ONGs são menores que os Institutos e Fundações, não estão atreladas a empresas ou instituições financeiras e precisam captar recursos externos. Há inclusive dois 
grupos distintos: a ABONG - Associação Brasileira das Organizações Não-Governamentais - e o GIFE - Grupo, Institutos e Fundações Empresariais.

Dentro dos diferentes tipos de ONGs, consideramos sobretudo duas categorias: as ONGs de mediação e as ONGs de intervenção, como exemplificaremos no item 4.2.3.

\subsubsection{ONGs e EDUCAÇÃO}

Talvez um dos temas mais caros aos movimentos sociais tenha sido, por muito tempo, o direito à educação. No Brasil, com as CEBs (Comunidades eclesiais de base) e outros órgãos da igreja, a educação foi, desde o princípio, adotada como um dever também da sociedade civil.

A importância da educação, na construção de uma sociedade democrática e na melhoria da qualidade de vida, se justifica, não porque a educação em si eleva a renda (apesar deste ser um índice real), mas porque ela fornece alternativas e ferramentas que permitem a formação de um ser político, entendido como aquele que reflete, critica e busca soluções, propiciando o fortalecimento democrático por permitir que os homens tracem seus próprios destinos e o destino de sua sociedade. A educação, portanto, amplia a conscientização e a participação democrática do povo, sendo assim libertária e um direito social inalienável.

São inúmeros os projetos envolvendo esta temática, desde a alfabetização e a educação de jovens e adultos até a preocupação com creches no âmbito da educação infantil, passando assim por todos os estágios da educação.

O exemplo da educação infantil é bastante relevante, pois foi na sociedade civil, por meio dos movimentos sociais, que este primeiro estágio educacional passou a ser admitido como de fundamental importância no percurso do educando e não simplesmente como um período em que as crianças somente brincam sem nada aprender. Hoje, sabemos que se direcionarmos as brincadeiras e jogos desde a mais tenra idade, haverá um ganho no que tange ao desenvolvimento de aspectos cognitivos e afetivos. O Estado hoje, a partir da LDB, é obrigado a oferecer a educação infantil, vitória garantida pelos movimentos sociais. 
A constante crise por que a educação vem passando no Brasil e o descaso do poder público criaram condições para a proliferação das ações de organizações nãogovernamentais, "passando das ruas e dos espaços das comunidades para o lado de dentro dos muros da escola" (Camba, 2004).

Segundo a mesma autora (Camba, 2004), uma das lutas que se travam agora, no campo educacional, pelos movimentos sociais, é pelo fim do assistencialismo e por mudanças efetivas nas práticas de ensino, para melhoria da qualidade de ensino das escolas públicas nacionais.

Azevedo (1997, p. 38) afirma que

se considerarmos que a maioria dos alunos chega ao Ensino Médio com sérias dificuldades ao ler e ao escrever, pode-se dizer que boa parte da infância brasileira não está analfabeta porque permanece à margem do sistema escolar, e sim porque passa pela escola sem aprender. Metaforicamente, a infância brasileira vem sendo, há muito tempo, analfabetizada pela escola.

Esse quadro requer, pois, uma transformação profunda na forma como a escola pensa estar ensinando. A relação entre a sociedade civil e a educação baseia-se, então, na busca de novas políticas públicas efetivas para a área.

Segundo um funcionário de uma ONG, citado no trabalho de Camba (2004),

Não é papel das ONGs substituir as obrigações do Estado, elas criam experiências modelos e exemplares, inovadoras, originais que podem vir a ser objeto de políticas públicas universais (...) essa seria a relação adequada, que as descobertas que se fazem nessas experiências poderiam ser apropriadas e destinadas a uma maior população (...) as ONGs atuam na Educação e ocupam espaços no sistema escolar num processo crescente de participação direta nas escolas públicas. Sua importância está situada na possível interferência em busca da "qualidade" da educação.

E a autora (2004) ainda explicita que

Com o apoio oferecido pelas instituições que financiam projetos na área da educação, o governo deixa de ser a única fonte de recursos para desenvolver as atividades das escolas, embora este ainda seja a principal fonte e o responsável por manter o ensino público e gratuito, que é direito de todo cidadão 
brasileiro. É aí que entra a nova parceria "sociedade civil e escola", por meio da comunidade, e onde as ONGs passam a ter uma atuação mais próxima e direta com as escolas públicas.

Sintetizando esta primeira luta, poderíamos dizer que a problemática do assitencialismo é o fato de que este não provoca transformações profundas e só "amacia" uma situação sem de fato ajudar a resolvê-la. Nas palavras de Paulo Freire (2002, p. 65-66), o assistencialismo

contradiz a vocação natural da pessoa - a de ser sujeito e não objeto, e o assistencialismo faz de quem recebe a assistência um objeto passivo, sem possibilidade de participar do processo de sua própria recuperação (...) o grande perigo do assitencialismo está na violência do seu antidiálogo, que, impondo ao homem mutismo e passividade, não lhe oferece condições especiais para o desenvolvimento ou a “abertura” de sua consciência que, nas democracias autênticas, há de ser cada vez mais crítica. (...) Daí as relações do assitencialismo com a massificação, de que é a um tempo efeito e causa.

\subsubsection{ONG e LEITURA}

Dentro deste amplo panorama da sociedade civil e suas propostas de mudanças, temos, no Brasil, muitas ONGs que trabalham para transformar o ato de ler (incluindo-se o contato com a literatura) numa prática cotidiana, trazendo uma experiência rica de leitura fora do mundo da escola, buscando inovar o relacionamento de jovens / crianças com o texto escrito. Pretendem também ajudar a transformar as práticas que se utilizam na escola, estabelecendo parcerias para colaborar no processo de formação de um país de leitores.

A luta destas ONGs pela difusão das práticas de leitura no Brasil dá-se por meio de diversos caminhos. Um exemplo são as ONGs de mediação que investem em pesquisas, em produção de material, organização de congressos / encontros e assessorias, culminando, por fim, num diálogo travado com o Estado e na influência e força que todo este movimento acaba por conquistar, interferindo nas políticas públicas para educação: opinando, dando sugestões e avaliando atentamente os passos dos governos.

Outras ONGs deixam este primeiro caráter mediador e partem para uma ação direta com a comunidade (ONGs de intervenção), reunindo financiamentos de empresas privadas ou 
fundações, para construir bibliotecas comunitárias e, assim, aumentar ou permitir o acesso de populações mais desfavorecidas aos mais diversos materiais escritos.

Entre estas, algumas buscam fortalecer a formação continuada de professores da rede pública, fornecendo cursos e palestras. A maior parte dos conteúdos trabalhados nestes encontros é originária de atividades bem sucedidas que foram previamente trabalhadas dentro das próprias organizações, uma vez que a maior parte das ONGs funcionam, conforme elas próprias denominam, como "laboratórios pedagógicos", nos quais a leitura é trabalhada com estratégias para viabilizar o prazer de ler. E outras, por fim, como veremos, passam a atuar diretamente com os alunos. 
Capítulo 5: PESQUISA DE CAMPO INICIAL: RELATO DAS VISITAS A DIVERSAS ONGs

No presente capítulo, intencionamos fornecer ao leitor um panorama dos trabalhos de cinco ONGs do campo educacional na cidade de São Paulo. Lembramos que este foi um recorte arbitrário das inúmeras organizações existentes na cidade - não houve um levantamento sistemático, uma vez que inexiste uma base de dados que os cubra por completo. Os motivos que nos levaram para cada ONG estudada aqui encontram-se na apresentação inicial de cada uma.

Em sua maioria, são relatos descritivos do ambiente e das atividades realizadas pelas organizações a partir de entrevistas com os coordenadores e, eventualmente, de observações feitas em campo. Todas as entrevistas foram realizadas com um gravador e estruturadas anteriormente. Em geral, foram feitas as mesmas perguntas para todos os coordenadores, buscando desta forma traçar um perfil das idéias sobre educação dos profissionais que trabalham no terceiro setor e saber que tipos de projetos estão sendo desenvolvidos.

Como mencionado no capítulo de metodologia, estes relatos constituem o que chamamos de "Pesquisa de campo inicial / exploratória", que durou em torno de quatro meses e teve como objetivo a escolha de uma organização para realizar esta pesquisa. Assim, foram visitadas diversas instituições com o intuito de encontrar aquela que possuísse disponibilidade de nos receber, bem como um projeto bem estruturado no campo da leitura e do desenvolvimento do letramento.

Ressaltamos que não foram realizados estudos exaustivos destas cinco organizações; portanto, as análises deste capítulo referem-se somente àquilo que foi observado, a partir de fragmentos / momentos. Desta forma, analisamos aqui estes momentos e não o conjunto do trabalho destas ONGs em questão.

A partir desta sondagem de terreno, extraímos alguns critérios e categorias, apresentando ao final um quadro comparativo, de modo a justificar a nossa escolha pela ONG 6, a ser apresentada no capítulo seguinte. 


\subsection{ONG 1}

A primeira instituição visitada foi a que originou esta pesquisa. Como já informado na apresentação, ao estagiar em uma escola estadual, observamos alguns alunos que vestiam a camiseta desta ONG e, conversando com eles, percebemos o importante papel que ela possuía no desenvolvimento da noção de responsabilidade, bem como no desenvolvimento intelectual e afetivo destes jovens. Os alunos demonstravam prazer e entusiasmo ao relatar as suas experiências nesta organização, ao contrário do que ocorria quando questionados sobre sua relação com a escola.

Em duas visitas, conhecemos as instalações e algumas atividades, observamos os educandos e realizamos uma entrevista com as coordenadoras pedagógicas.

Previamente, havíamos marcado a entrevista com a coordenadora pedagógica dos jovens de 14 a 18 anos, Rosa, psicóloga, trabalhando há alguns meses na ONG. Ao chegar para a entrevista encontramos também a coordenadora pedagógica das crianças de 5 a 13 anos, Ana, na instituição há seis anos, chamada por Rosa para auxiliá-la. Ambas se mostraram abertas e atenciosas, dispostas a responderem todas as nossas perguntas e a permitirem, eventualmente, um trabalho de campo na instituição. No entanto, durante a conversa mantiveram-se um pouco desconfiadas e preocupadas em mostrar claramente os bons resultados de seus projetos. Esta entrevista teve duração de uma hora e meia.

\subsubsection{HISTÓRICO, PROJETO PEDAGÓGICO E ESTRUTURA}

\subsubsection{HISTÓRICO}

Ao iniciar a entrevista, Rosa fez um relato sobre a fundação da organização, surgida a partir de um trabalho feito por terapeutas florais, e que se tornou agora uma ONG de educação integral unida à área da saúde alternativa.

A organização começou suas atividades a partir de 1992. Inicialmente, como um programa social baseado, sobretudo, em um trabalho voluntário dedicado a crianças que vendiam doces nos faróis da cidade. Tal trabalho foi realizado por um grupo de terapeutas 
florais que acreditavam na eficácia de aliar o incremento da auto-estima a gotinhas de florais para resgatar das ruas crianças em situação de risco.

Em 1993, as atividades foram institucionalizadas e o programa social transformou-se em uma ONG com o objetivo principal de educar crianças e adolescentes em situação de risco por meio de um trabalho qualificado. No "folder" da ONG, foi possível verificar que ela afirma

promover o desenvolvimento integral, pessoal e social de crianças, adolescentes e suas famílias em situação de risco, por meio de ações nas áreas sociocultural, educacional, ambiental, de geração de renda, profissionalização e saúde tradicional e alternativa.

Segundo Rosa, a ONG foi constituída para suprir uma necessidade deixada pelo Estado, que não consegue atender a população local.

\subsubsection{PARCERIAS}

Hoje, a instituição sobrevive por meio de parcerias estabelecidas com empresas, instituições financeiras, outras ONGs e profissionais liberais dispostos a trabalharem como voluntários.

Alguns projetos específicos são financiados por empresas que exigem acompanhamento, bem como demonstração de resultados. Em outros projetos, funcionários das empresas parceiras da ONG participam como voluntários.

Os educandos do programa social ainda têm a oportunidade de serem certificados pelo SENAI nas oficinas de serigrafia, silkscreen e reciclagem de papel.

\subsubsection{PROJETO PEDAGÓGICO}

No início, de acordo com Rosa, "cada educador fazia o seu próprio trabalho de maneira independente, embora houvesse na linha de pensamento comum, uma visão holística e integral do ser humano”. Deste modo, tentavam integrar diversas áreas, entre elas a da saúde alternativa, unindo o desenvolvimento da mente ao do corpo. 
Porém, não havia propriamente um projeto pedagógico concreto, uma metodologia de trabalho comum, pois segundo Rosa

(...) tudo acaba ficando um pouco aberto, porque cada educador atua com a sua própria visão de mundo e de educação. Isso acabou gerando choques de idéias e conflitos dentro do grupo... a gente não tinha um espaço-tempo para se chegar a um acordo do que se queria para as crianças que entravam na organização com 5 anos $e$ saíam com 17.

Assim, mesmo após 13 anos de existência, o projeto político-pedagógico da organização, segundo suas coordenadoras, ainda estava em fase de finalização. Ana afirmou que este projeto estava sendo construído paralelamente a um relatório a pedido de um dos parceiros financeiros. Ou seja, até que fosse demandado por um dos parceiros financeiros, a ONG não havia se preocupado, em todos estes anos, em criar o seu próprio projeto pedagógico.

Rosa afirmou que a metodologia utilizada pela ONG agora baseia-se no conceito de "educação interdimensional”, ou seja, "que toda atividade precisa estar voltada para as quatro dimensões do ser humano: o sentimento (pathos: aprender a lidar com as emoções), o corpo (eros), a espiritualidade (mythos: valores humanos, projeto de vida, que tipo de ser humano eu gostaria de ser), e o conhecimento (Logus)".

Esta metodologia é proveniente de uma capacitação da qual participam os educadores da ONG, realizada por um instituto de uma empresa da área financeira em parceria com o pedagogo e idealizador do trabalho, Antonio Carlos Gomes da Costa, autor da apostila que tem sido distribuída em diversas organizações.

A primeira etapa do programa de Gomes da Costa consiste em formar os educadores dentro de sua metodologia por um período de dois anos. Para tanto, a ONG recebe verbas do instituto da empresa

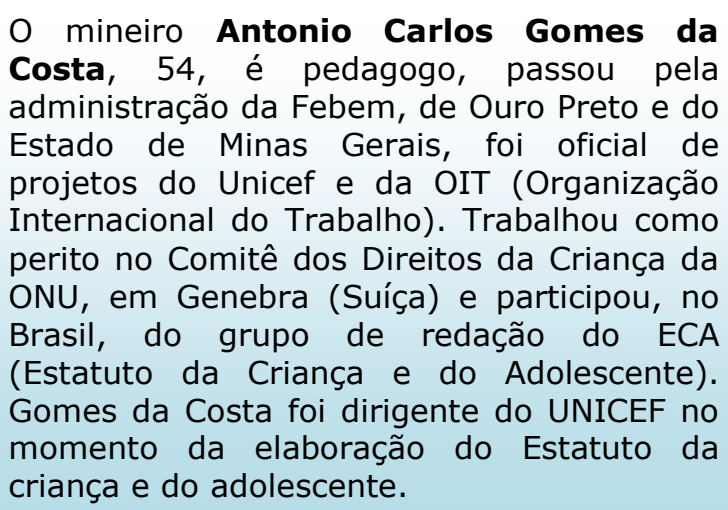
Estado de Minas Gerais, foi oficial de projetos do Unicef e da OIT (Organização Internacional do Trabalho). Trabalhou como perito no Comitê dos Direitos da Criança da ONU, em Genebra (Suíça) e participou, no Brasil, do grupo de redação do ECA (Estatuto da Criança e do Adolescente). Gomes da Costa foi dirigente do UNICEF no momento da elaboração do Estatuto da criança e do adolescente. 
financeira. Os educadores se reúnem uma vez por semana para discutir os conceitos da "educação interdimensional" e pensar suas oficinas sempre a partir dos quatro eixos propostos pelo pedagogo. Segundo Rosa, os educadores já trabalhavam com estes conceitos de maneira intuitiva, mas, pela primeira vez, estão estruturando seus trabalhos baseados em uma metodologia.

Como poderá ser observado mais adiante, o fato desta ONG permanecer anos sem um projeto pedagógico não foi, infelizmente, uma exceção dentro da análise dos cinco casos que constituem este capítulo. Portanto, percebemos ser comum as ONGs não trabalharem e / ou não apresentarem um projeto pedagógico concreto. Em geral, por se originarem de maneira casual, acabam perpetuando uma certa informalidade nociva ao desenvolvimento de práticas educacionais efetivas. Nesta ONG, por exemplo, foram apresentados conceitos abstratos de educação ("educação para decisão") e objetivos ainda mais genéricos ("criar cidadãos"), sem terem refletido sobre o significado destes conceitos e nem nas etapas e projetos pedagógicos que permitiriam o alcance desses objetivos.

\subsubsection{AVALIAÇÃO}

A avaliação é feita individualmente por meio de registros dos educadores, não existindo um documento que seja generalizado. A observação do comportamento dos educandos durante o seu período na ONG é a fonte principal desta avaliação, na qual os educadores verificam se os participantes estão atingindo ou não os objetivos propostos nas atividades. O intuito destas observações é saber se as atividades planejadas são eficientes ou se algumas delas precisam ser repetidas ou aprofundadas.

Algumas vezes, as avaliações são feitas a partir de produções escritas da "Oficina de Comunicação": depois do texto entregue, uma voluntária revisa o texto e, posteriormente, o re-escreve junto com os jovens; numa terceira etapa, em esquema de rodízio, revisam e reescrevem o texto mais uma vez. Segundo Rosa, os jovens se preocupam em melhorar o texto, principalmente porque sabem que a matéria que escreveram vai sair no jornal da ONG e será lida pela comunidade, por seus pais e colegas.

Já as crianças pequenas passam por avaliações em ambos os semestres, pois o objetivo é, de acordo com a coordenadora, a "prontidão para a alfabetização". 


\subsubsection{FUNCIONAMENTO DA ORGANIZAÇÃO}

Todos os participantes estão matriculados em escolas da rede pública. Assim sendo, em um período eles vão à escola e, no outro, para a ONG.

Por ser uma instituição conhecida há muito tempo no bairro, a ONG afirmou não precisar buscar novos participantes. Os educandos vêm procurar a instituição depois de terem ouvido comentários sobre ela de outras crianças / jovens que já fazem parte da casa. Atualmente, existe uma longa lista de espera para ingressar na ONG, e os critérios de seleção são definidos a partir da renda familiar, da época da inscrição na lista e do fato de haver ou não irmãos que já participam do projeto. Aqueles que já possuem algum familiar na ONG têm preferência, pois segundo as coordenadoras o intuito é atender a família como um todo.

\subsubsection{REGISTRO DE PRESENÇA E PERMANÊNCIA NA ORGANIZAÇÃO}

A ONG registra e requer presença mínima dos educandos. São permitidas até três faltas justificadas por mês; caso contrário, eles perdem as vagas. Há educandos que são desligados do programa após algumas tentativas de diálogo, por continuarem se mostrando desinteressados, sem motivação, ou por lá estarem apenas pela bolsa e refeições que recebem.

Esta questão parece bastante delicada no que se refere aos inúmeros projetos sociais existentes, e pode-se até levar ao questionamento do sucesso da ONG. Podemos nos perguntar se o trabalho desenvolvido está realmente fazendo alguma diferença no processo educacional e no desenvolvimento cognitivo de crianças e adolescentes ou se o grande número de alunos atendidos deve-se somente ao auxílio alimentação / financeiro. Este auxílio é importante, especialmente por ajudar a evitar que os alunos tenham que trabalhar ao invés de estudarem e participarem das atividades da ONG, mas então como fazer com que eles se interessem sem que sejam desligados?

Em geral, a permanência dos educandos na organização dura alguns anos (dois ou três). Quando ocorre evasão, isso ocorre, de acordo com Rosa, em função de mudanças de endereço e devido à necessidade de ingresso dos jovens no mercado de trabalho. A maioria não possui a perspectiva de continuar os estudos pela falta de condições financeiras. 
Depois que atinge 18 anos, o jovem não pode mais participar das atividades promovidas pela ONG e não há um encaminhamento para o campo de trabalho.

\subsubsection{PROFISSIONAIS E VOLUNTÁRIOS}

Os educadores que trabalham nas oficinas da ONG não são voluntários, mas profissionais contratados com formação em nível superior compatível com a oficina que ministram. Existem, portanto, pedagogos (que atuam com a faixa etária de 5 a 10 anos), artistas plásticos (oficinas de artes), profissionais formados em cinema e jornalismo (oficina de comunicação) e um estagiário cursando o $2^{\circ}$ ano de pedagogia. Há sempre um educador para cada turma e nas turmas de 5 a 7 anos há também uma auxiliar.

Já os voluntários (na maior parte moradores da região) trabalham no que a organização chama de atividades que ocorrem no máximo uma vez por semana. Para fazer um trabalho voluntário, deve-se participar de uma reunião mensal, aos sábados, com o intuito de conhecer a casa e preencher um cadastro no qual explicitam o que gostariam de fazer para ajudar a instituição e que tipo de atividade os interessaria. Atualmente, há voluntários que são responsáveis pelas atividades de teatro e de artes, bem como voluntários na área administrativa e na área de vendas de produtos feitos pelos participantes da ONG. Normalmente, as atividades recreativas coordenadas por voluntários acontecem aos sábados.

\subsubsection{ESTRUTURA}

A ONG em questão localiza-se em um bairro de classe média da zona sul de São Paulo, atendendo crianças e adolescentes que habitam duas favelas da região, ambas localizadas ao longo da Av. Jornalista Roberto Marinho. Os participantes da organização estão matriculados em duas escolas públicas próximas, uma estadual e a outra municipal (a matrícula na escola é requisito obrigatório para a participação do educando na instituição).

Suas instalações estão divididas por quatro unidades no mesmo bairro e duas outras em bairros diferentes, porque cada unidade possui um espaço bastante limitado. 
Há a sede da organização, onde os educandos realizam atividades, como: oficina de comunicação; oficina artística; acompanhamento escolar; aulas de língua, computação, comportamento e educação para o trabalho; "aulas" na pré-escola; utilização da brinquedoteca e da biblioteca; sessões de filmes e horários de refeições. O prédio foi doado pelo DER (Departamento de Estradas e Rodagem) e consiste em dois andares.

No primeiro andar, há um salão relativamente grande que possui um equipamento de televisão, vídeo e DVD, bem como uma lousa e cadeiras. É neste salão que ocorrem também as sessões de cinema abertas para a comunidade.

Ainda no primeiro andar, há uma sala destinada aos professores e à administração, a recepção, um banheiro, um consultório dentário (onde dentistas voluntários atendem os participantes da $\mathrm{ONG}$ ), uma despensa, um pequeno laboratório de vídeo que comporta no máximo três pessoas (há bons equipamentos para a elaboração e edição de vídeos e de jornais), e um bazar que vende peças doadas e produtos manufaturados pelas mães e jovens participantes. No fundo da casa, há o refeitório e a cozinha. A área livre possui um pequeno pátio e um playground para as crianças pequenas.

No segundo andar, há o escritório das coordenadoras pedagógicas e administrativas, banheiros, um pequeno consultório terapêutico construído por divisórias (psicólogas e terapeutas florais voluntárias atendem os participantes), a biblioteca unida ao laboratório de informática, uma pequena sala de pré-escola para crianças de 5 a 6 anos que comporta no máximo dez educandos e uma brinquedoteca.

A estrutura geral é bastante simples, mas nota-se um esforço para transformar o espaço em um ambiente agradável e prático. Quase tudo provém de doações, o que confere um aspecto um pouco desgastado aos móveis, livros e brinquedos em geral, no entanto, os equipamentos eletrônicos são todos novos.

As instalações estavam quase todas vazias no momento da visita, pois, sendo fim da tarde, as crianças e jovens estavam indo embora. Assim, as salas estavam com as luzes apagadas e por isso pareceram um pouco frias e escuras. 
As outras unidades da organização constituem-se de: uma quadra esportiva, onde os participantes praticam esportes de quadra, capoeira, aikido e dança de salão; um atelier de reciclagem; um atelier de artesanato para as mães dos participantes e que serve também como espaço do projeto "Eu quero e posso ser feliz" (projeto de auto-estima e profissionalizante para as mães); um depósito de doações; e um abrigo para crianças que por algum motivo foram retiradas de seus lares. Excetuando-se a sede principal e a quadra, que são propriedade da ONG (doadas pelo DER), as outras unidades são somente emprestadas para a organização, pelo mesmo DER.

\subsubsection{BIBLIOTECA}

A biblioteca, como fonte de material de leitura, constitui-se somente de livros (não possui revistas, jornais ou videoteca) e está organizada em estantes de metal. As estantes não possuem um espaço adequado entre si, ficando extremamente próximas e tornando inviável a busca. Os livros estão organizados por categorias como: literatura infantil, literatura brasileira, literatura estrangeira etc.

Não existe uma bibliotecária e os livros não se encontram catalogados; assim, perguntamo-nos então como seria o controle da saída dos livros, se é que ele existe. No centro deste espaço, há quatro grandes mesas unidas formando uma só, com dez cadeiras em volta: este é o espaço de leitura. Ao longo das paredes existem por volta de dez computadores. A sala é um pouco escura e bem apertada.

O espaço é claramente inadequado e nada convidativo para qualquer atividade de leitura. Desta forma, espera-se que ninguém queira lá permanecer e sobretudo ler em um espaço escuro e apertado. A biblioteca está montada em um canto qualquer, no espaço que restou. A mensagem que isso passa é que ela não é importante, portanto a leitura também não o é. Não adianta possuir livros, se estes não estão ao alcance dos educandos: se o espaço entre as prateleiras é insuficiente para permitir o deslocamento de uma pessoa, como se alcançam os livros que lá estão? 


\subsubsection{PROJETOS}

Hoje, existem as oficinas diárias e também projetos/atividades que são programados e planejados anualmente. Por três vezes, realizaram o projeto proposto pela Comunidade Solidária, da socióloga Ruth Cardoso, por meio do qual prepararam os educandos para o mercado de trabalho e finalizaram o projeto com o estágio dos educandos em empresas.

As atividades sócio-educativas promovidas pela ONG são as oficinas de teatro, música, atividades esportivas, informática, história. Quando questionadas, as coordenadoras tiveram um pouco de dificuldade para se lembrarem de todas as oficinas oferecidas, não mencionando diversas atividades que constam no folder da instituição como: jardinagem, acompanhamento escolar, aikido, capoeira, coral, dança de salão, aulas de línguas (espanhol, francês, inglês), xadrez, serigrafia, mosaico e alfabetização de pais. Tal dado colocou-nos em dúvida sobre o real funcionamento de todas estas oficinas nesta ONG.

Segundo Rosa, a intenção não é manter um currículo como o da escola oficial, onde há aulas de matemática, ciências, geografia, língua portuguesa etc. No entanto, segundo ela, os conteúdos destas matérias são trabalhados indiretamente com os educandos a partir de atividades e oficinas. O trabalho com as disciplinas escolares acontece ao longo das atividades, mas não é seu foco principal. As atividades propostas, de acordo com Rosa, procuram ser dinâmicas, envolver o aspecto lúdico, serem light e ensinar fora do esquema professor-lousa-caderno-sala de aula, que Ana afirma ser um esquema de cópias e de "sentar e ouvir o professor falar o tempo todo". Um exemplo dado por Rosa é o trabalho na horta, que envolve um trabalho ambiental (ciências) e matemático (ao calcularem o número de sementes necessárias).

Como afirma Ana, a intenção é manter-se, o mais possível, afastado do currículo escolar, pois a organização não pretende reprisar o que os educandos viram na escola. Segundo ela, no início da história da ONG, havia uma preocupação em se estabelecer um paralelismo com o conteúdo trabalhado na escola, por isso havia até reforço escolar (a partir desta afirmação de Ana concluímos que não deve haver mais, apesar de continuar constando no folder da instituição), o que não trouxe nenhum resultado positivo, principalmente com relação aos educandos do período da tarde, que chegavam cansados e já desmotivados para enfrentar mais uma tarde de reprodução do modelo escolar. 
Os participantes são divididos em grupos por faixas etárias: 5 e 6 anos, 7 a 10 anos, 11 a 13 anos e 14 a 18 anos. A escolha por faixa etária, e não por turmas seriadas, foi feita, segundo Ana, pela falta de espaço nos prédios da ONG. A maioria das atividades é realizada no prédio-sede, somente as aulas de informática ocorrem em outro espaço: em uma escola particular parceira da ONG e que dispõe de seus alunos como monitores.

\subsubsection{OFICINA DE COMUNICAÇÃO}

A "Oficina de Comunicação" é um dos projetos que mais nos interessou nesta pesquisa por envolver diretamente a questão da linguagem. Ela funciona somente no período da tarde com uma turma de 20 jovens de 14 a 18 anos, e é orientada por dois profissionais, sendo um graduado em Cinema e o outro em Jornalismo.

Nesta oficina, os jovens aprendem a fazer vídeos e produzem um jornal chamado "Favel'ativa", com notícias escritas pelos educandos referentes a acontecimentos da comunidade como: problemas domésticos, campeonato de futebol, a condição de pobreza, a necessidade de deixar a escola para trabalhar, o preconceito, tuberculose e artistas da favela. Os educandos são responsáveis pela produção do jornal, desde a criação do texto até a sua diagramação.

O financiador do projeto paga o material e remunera os educadores, além de fornecer uma bolsa-auxílio para cada jovem participante no valor de $\mathrm{R} \$ 150,00$ e uma cesta básica. Assim, os educadores, junto com os jovens, decidiram que uma parte desta bolsa deve ser utilizada para o processo educativo de cada um, de maneira que deve, com certa frequiência, ser destinada à compra de livros, CDs, idas ao cinema ou ao teatro. É preciso ressaltar que todas estas atividades são realizadas por decisão do educando, partindo da responsabilidade de cada um e de seu comprometimento pessoal com a sua própria educação. Os jovens deste grupo lêem, de acordo com Rosa, um livro a cada dois meses para esta oficina. Algumas vezes, o educador propõe trabalhar com um filme que esteja em cartaz e os educandos vão assisti-lo para depois participarem de um debate e realizar trabalhos a partir desta experiência cultural. 
A ONG não possui um projeto direcionado especificamente ao estímulo à leitura, literária ou não. Entretanto, Rosa afirma que em todas as atividades e oficinas de todas as faixas etárias há momentos em que a língua portuguesa é trabalhada, uma vez que se percebe claramente a dificuldade dos educandos em se expressarem por meio da modalidade escrita da língua: ao escrever e ler. Rosa diz que o objetivo de seu trabalho é desenvolver cidadãos, ou seja, que o cidadão possa saber "as coisas básicas da vida: no mínimo ler, escrever e fazer contas". Porém, mais uma vez não souberam afirmar como a língua portuguesa é trabalhada nas diferentes atividades e oficinas.

Para os educandos de 5 e 6 anos, um dos objetivos é, segundo Rosa, a "prontidão" para a alfabetização. São as únicas crianças da organização que não estão na escola. Para elas é realizado somente um trabalho lúdico com a linguagem.

Dos 7 aos 13 anos, as crianças participam de atividades de contação de histórias, música e teatro, de maneira a viabilizar um contato maior com livros e revistas. Esses materiais são provenientes de doações.

\subsubsection{A ONG E A ESCOLA PÚBLICA}

A visão que a ONG tem da escola pública foi definida pelas coordenadoras pedagógicas como "aquela que todo mundo tem, de muitas falhas e problemas". Ana lembrou-se dos tempos em que estudou na escola pública de alta qualidade, sem considerar, no entanto, que a saudosa escola pública de outros tempos, era também elitista e, portanto, excludente. Faltou um olhar mais crítico na visão da coordenadora pedagógica em relação à escola pública, apresentando um ponto de vista arraigado no senso comum brasileiro, sem uma reflexão mais consistente.

A ONG trabalha, sobretudo, com alunos de duas escolas, uma estadual e outra municipal. Ao longo do tempo, Ana afirmou estabelecer contato com as coordenadoras das escolas. Segundo Rosa, estes contatos são importantes, uma vez que permitem trocar informações a respeito dos alunos e estabelecer comparações de comportamento e rendimento na escola e na ONG. A partir destes contatos, Rosa acredita também que existe "uma melhora efetiva da atitude geral e do rendimento escolar dos educandos que entram no projeto da $O N G$ ", sem, no entanto, possuir dados estatísticos ou ter realizado uma pesquisa 
com os participantes e suas famílias. Ela julga que a melhora no comportamento deve-se ao trabalho feito na organização relativo à responsabilidade e motivação, que serve também aos interesses da escola.

Algumas vezes, a ONG e a escola conseguiram realizar trabalhos em parceria, porém são poucos os sucessos neste tipo de investida, pois, de acordo com Ana, há um movimento muito grande, praticamente anual, de coordenadoras e diretoras na rede pública de ensino. Dessa forma, os projetos desenvolvidos foram pontuais e sem continuidade.

Tendo em vista que existe a intenção de manter um elo com a escola, pois é um dos objetivos da ONG, tem sido difícil manter, segundo as coordenadoras, uma relação de parceria constante com a rede pública. Nos últimos tempos, alguns jogos esportivos foram realizados entre a organização e a escola, mas, no momento, a relação com a escola é muito restrita.

Apesar das afirmações feitas pelas coordenadoras, o contato com as escolas públicas não pareceu ser uma questão central para a ONG. A própria organização parece querer se distanciar da escola quando apresenta desculpas para a falta de relacionamento com o sistema público e por insistir em querer sempre se manter longe do "currículo escolar" e de tudo aquilo que se refere ao estudo formal, fazendo alusão exclusiva às suas conotações negativas, como vimos no item 5.1.2. 


\subsection{ONG 2}

A ONG 2 é uma organização bastante conhecida, principalmente por ter sido contemplada com inúmeros prêmios, inclusive o da UNESCO. Fomos visitá-la com base no seu reconhecimento público e devido também a suas inúmeras propagandas (rádio e TV), que sempre afirmavam trabalhar com a leitura. As visitas foram realizadas sempre nas últimas sextas-feiras do mês e precisaram ser agendadas.

Nesta ONG, conhecemos as instalações e assistimos a uma palestra com slides e vídeo apresentada por dois jovens da comunidade (um rapaz de 18 anos e uma moça de 17), agora transformados em mediadores culturais. Havia em torno de 25 pessoas, entre elas: estudantes universitários, interessados em participar e ajudar a fundação e pessoas que buscavam fundar suas próprias organizações.

Ambos os mediadores apresentavam a palestra pela primeira vez e, apesar de serem muito atenciosos e esforçados, estavam visivelmente nervosos e apresentaram dificuldade em responder às perguntas feitas pelos espectadores. Havia, na palestra, uma coordenadora que tentou responder algumas perguntas, porém de maneira superficial e vaga. Tentamos, posteriormente, conversar com a coordenadora pedagógica, que prometeu entrar em contato para marcarmos uma entrevista, mas que nunca o fez.

A dificuldade de contato com os coordenadores das ONGs foi uma constante, e nesta ONG sentimos pouca disponibilidade de aceitação de pesquisadores. Ignoram, assim, a possibilidade do pesquisador ser também um parceiro, na medida em que pode apontar falhas, mas também pontos positivos com o intuito de melhorar as atividades analisadas. Isso nos levou a pensar que pode haver um receio em se deixar pesquisar, o que nos fez questionar a qualidade do trabalho feito nesses espaços, uma vez que, se acreditassem verdadeiramente estar fazendo um bom trabalho, não haveria problema em aceitar a inserção de um pesquisador.

Ainda nesta primeira visita tivemos a oportunidade de conversar com Daisy, pedagoga e professora da "Oficina de Leitura e Escrita" de crianças de 12 anos, há três anos na fundação. Esta conversa foi gravada e durou cerca de 45 minutos. 


\subsubsection{HISTÓRICO, PROJETO PEDAGÓGICO E ESTRUTURA}

\subsubsection{HISTÓRICO}

A ONG foi fundada em 1998 por dois atletas brasileiros com o intuito de "contribuir para a formação educacional e cultural de crianças e jovens para que possam atuar com autonomia na transformação de suas realidades". Tal fundação possui duas unidades, uma em São Paulo, outra em Niterói, RJ.

Em 2001, a fundação foi reconhecida pela UNESCO como modelo mundial no apoio a crianças desfavorecidas, "por desenvolver um trabalho que envolve a comunidade, reforça o papel da escola e aumenta a auto-estima de crianças e adolescentes". Em um dos corredores do prédio, há inúmeros certificados e prêmios recebidos pela instituição, incluindo documentos expedidos pelo Ministério do Desenvolvimento Social e Combate à Fome, pelo Ministério Público e pela prefeitura de São Paulo.

\subsubsection{PARCERIAS}

Para seu funcionamento, a fundação conta com parcerias financeiras e institucionais de mais de 30 empresas, além de apoio governamental (Governo do Estado de S.Paulo, Ministério da Cultura, BNDES) e da UNESCO. Há ainda a colaboração que vem de sócios titulares (pessoas físicas que colaboram mensalmente com doações) e de profissionais voluntários que dedicam seu tempo para ajudar o desenvolvimento das crianças e participantes da ONG. No início da fundação, ela teve apoio do governo, que cedeu o prédio e financiamento do BNDES.

A fundação afirma ainda ter outros tipos de parcerias, com a preocupação em não trabalhar sozinha; ela diz procurar apoio das famílias, da comunidade, da igreja e das escolas, ou seja, de diferentes ambientes de convivência dos participantes, procurando assim sanar ou ajudar a resolver problemas. 


\subsubsection{PROJETO PEDAGÓGICO / METODOLOGIA}

O planejamento pedagógico é feito junto à área social. Os coordenadores organizam o calendário e as atividades anualmente, em parceria com os professores. Alguns projetos, como o "Virando o jogo", são planejados por temas.

A metodologia de trabalho ainda está em processo de sistematização. Mais uma vez temos uma ONG com vários anos de fundação ainda sem um projeto pedagógico pensado e elaborado. Somente após seis anos de trabalho com as "Oficinas de Leitura e Escrita" e com a "Formação de Agentes Comunitários", a fundação está realizando um levantamento que procura saber qual o impacto destas atividades na comunidade e na família. Portanto, não há um projeto pedagógico formatado, uma vez que afirmaram estar em processo de avaliação e ainda ser preciso analisar e considerar o que foi positivo durante estes anos de trabalho, bem como a viabilidade de projetos futuros.

Por enquanto, as turmas são divididas por idades e numeradas de 1 a 6 . As turmas 1 e 2, 3 e 4 e 5 e 6 fazem sempre os mesmos projetos que estão programados e delineados desde o início do ano.

A cada ano, os educadores trazem alguns temas e projetos que gostariam de realizar e conversam com os educandos, procurando ouvir suas opiniões. Se a idéia for bem recebida, o projeto é desenvolvido, caso contrário, os educadores junto com os participantes da ONG buscam encontrar um novo tema a ser trabalhado.

Os temas procuram ser de interesse dos educandos e relacionados com seu contexto. No ano de 2004, uma turma trabalhou o RAP, fazendo pesquisas sobre música. Em 2005, as turmas 5 e 6 (jovens) trabalharam em um projeto chamado "Adolescente", no qual realizaram uma pesquisa perguntando para outros adolescentes suas opiniões sobre música, moda, arte, etc. Aproveitaram para gravar um vídeo, exibido no final do ano, e montar uma exposição com cartazes.

Há uma festa no meio do ano, para apresentar o projeto encaminhado, e uma no fim do ano, essa aberta ao público, na qual todos os trabalhos realizados pelos educandos são expostos. 
Os focos principais de trabalho, nesta fundação, são a arte-educação, a prática esportiva e a literatura e a escrita. Segundo a $\mathrm{ONG}$, tais elementos são a base para o desenvolvimento da auto-estima, comunicação, solidariedade e sociabilidade.

\subsubsection{AVALIAÇÃO E ACOMPANHAMENTO ESCOLAR}

A coordenadora, presente na palestra, afirmou ser feito um acompanhamento escolar dos educandos a cada dois meses. Assim, cada uma das coordenadoras da ONG passa pelas escolas em que os educandos estão matriculados para conversar com as professoras, verificando freqüência, comportamento e notas. Depois, estes dados são levados para a área pedagógica que se encarrega, se for necessário, de conversar e orientar seus participantes, auxiliando a escola e colaborando para a melhoria de seu desempenho escolar.

\subsubsection{FUNCIONAMENTO DA ONG}

Atualmente, 180 crianças e adolescentes são atendidos diariamente ao longo de uma carga horária de 20 horas semanais.

Existem dois horários de funcionamento da fundação: o matutino, das $8 \mathrm{~h}$ às $11 \mathrm{~h} 30$, e o vespertino, que vai das $13 \mathrm{~h} 30$ às $17 \mathrm{~h} 30$.

\subsubsection{REGISTRO DE PRESENÇA}

A falta é controlada e, segundo a fundação, estabelece-se um senso muito forte de responsabilidade. Se a criança faltar muito, os assistentes sociais da ONG vão até a casa do educando se informar sobre o motivo de tantas ausências.

\subsubsection{PROFISSIONAIS E VOLUNTÁRIOS}

Os educadores são profissionais contratados pela fundação e graduados na área em que trabalham (pedagogia, letras, artes plásticas, educação física etc.). Há ainda os 
mediadores em formação, jovens da comunidade que auxiliam os educadores ou mantêm atividades paralelas na ONG, como a contação de histórias.

\subsubsection{ESTRUTURA}

Esta fundação está localizada em um bairro pobre da zona norte da cidade de São Paulo. Não há placas que identifiquem o local, instalado em um prédio bem conservado de uma antiga escola pública desativada e doado pelo Governo do Estado.

A unidade paulista é espaçosa $\left(1.600 \mathrm{~m}^{2}\right)$, com muitas salas de aula, refeitório, quadras esportivas, auditório, biblioteca, escritórios, salas de reunião, banheiros, cozinha, sala de produção de vídeo/audiovisual e sala de leitura. Possui uma boa infra-estrutura, especialmente por estar em uma instalação que anteriormente foi uma escola (desativada por possuir um número restrito de alunos). Nesta unidade são realizados projetos de artes visuais, dança, música, teatro, além de práticas esportivas, trabalho de leitura e escrita, aulas de informática e inglês, mediação de leitura, espaço para jogos e brinquedoteca e também atividades de recreação.

\subsubsection{BIBLIOTECA}

A biblioteca foi montada por meio de doações e está aberta também para a comunidade local, transformando-se em uma nova alternativa cultural para a população. Ela está bem instalada em uma sala ampla, mas pouco iluminada.

São cerca de 12.000 livros organizados e catalogados, em prateleiras novas de madeira, por categorias: literatura adulta, literatura juvenil, literatura infantil, educação, direito, dicionários, história, gibis, revistas etc. Há também computadores na sala para uso de internet (utilizados somente com permissão), e uma mesa com computador para a bibliotecária.

Segundo a bibliotecária, estão inscritas 1060 pessoas na biblioteca e são retirados em torno de 400 a 500 livros por mês, na maioria, romances. No início, de acordo com a bibliotecária, as crianças retiram mais gibis, com o tempo e devido às atividades de leitura, elas passam a retirar também livros infantis. 
As crianças e jovens participantes da fundação possuem uma hora diária para visitarem a biblioteca e lerem na sala anexa. As atividades de leitura são normalmente direcionadas por mediadores ou educadores e relacionadas a um projeto temático previamente estabelecido.

Anexa à biblioteca, a sala de leitura é bem iluminada e possui almofadões espalhados pelo chão, suprindo uma necessidade da biblioteca que não possui no seu espaço mesas ou cadeiras para sentar, ler ou estudar. Assim, os sócios da biblioteca devem se dirigir à sala de leitura ou a outra sala de aula (se quiserem se sentar) para poderem ler.

Durante esta visita, observamos a sala de leitura (que possui uma porta de vidro) em uso; nela, crianças de 7 a 9 anos estavam sentadas em círculo ouvindo uma das mediadoras contar uma história. Ela segurava o livro no colo e virado para a turma de forma que as crianças pudessem acompanhar com os olhos.

A biblioteca da ONG 2 tem a melhor estrutura de todas as ONGs analisadas. Está bem estruturada em um espaço adequado, é bonita, organizada e convidativa para atividades de pesquisa e leitura. A sala anexa com almofadões e iluminação natural é ótima para as crianças. Só faltou um espaço de leitura e estudo com mesas e cadeiras. Há claramente um esforço da ONG para que a biblioteca seja um espaço vivo, o que é bastante positivo.

\subsubsection{PROJETOS}

Dentre os inúmeros projetos desenvolvidos pela ONG, três são os principais e mais bem estruturados:

\subsubsection{PROGRAMA "VIRANDO O JOGO"}

O programa principal da fundação chama-se "Virando o jogo" e baseia-se, sobretudo, na complementação escolar. Ele atende 240 crianças e adolescentes de 7 a 14 anos que têm a oportunidade de praticarem esportes, trabalharem com atividades artísticas e aperfeiçoarem suas habilidades de leitura, escrita e informática. As crianças são divididas em grupos de 15 a 
20 por oficina, para facilitar e permitir o trabalho dos educadores. O critério para participação nas atividades da fundação é socioeconômico.

Segundo a ONG, todas estas atividades não são caracterizadas como reforço escolar e sim como complementação, trazendo algo novo e diferente do que é trabalhado na escola - se não pelo conteúdo, pelo menos pela forma com que a leitura e a escrita, por exemplo, são trabalhadas.

A cada dois meses, em um sábado, o prédio da fundação se abre como um espaço alternativo de lazer para a comunidade, sempre em torno de um tema ou finalidade, como: a geração de renda, a oportunidade de tirar a carteira de trabalho e a participação em oficinas de marcenaria.

\subsubsection{PROGRAMA DE FORMAÇÃO DE AGENTES COMUNITÁRIOS (FAC)}

Este programa atende 560 jovens (S.Paulo), de 15 a 21 anos, que trabalham com artes, comunicação, informática e esportes e, a partir destas experiências, constroem uma visão mais crítica do mundo e do seu cotidiano social e cultural. O projeto tem como objetivo final transformar estes jovens em agentes comunitários e monitores para as diversas atividades da fundação. Um exemplo de monitores formados pelo FAC foram os nossos anfitriões, Anderson e Camila.

\subsubsection{BIBLIOTECA COMUNITÁRIA}

A biblioteca anteriormente descrita é o núcleo do programa "Biblioteca comunitária". Paralelamente ao espaço, há um trabalho direcionado para a formação de jovens e adultos da região em monitores e mediadores de leitura. Os monitores formados passam a realizar atividades como contação de histórias e mediação de leitura.

A biblioteca também permite o acesso à Internet para trabalhos e pesquisas.

Para garantir as estratégias de constituição de leitores, há uma programação cultural com exposições, leituras dramáticas, concertos de música, além da viabilização do acesso da comunidade a um acervo de livros, vídeos, CDs e periódicos. 


\subsubsection{FUNDAÇÃO E ESCOLA PÚBLICA}

A fundação tem a preocupação de levar alguns projetos, por meio de eventos, para a escola pública, como forma de permitir a participação da escola também. Um exemplo dado por Camila foi a oficina de fotografia, que expôs o seu trabalho final nas escolas.

Os monitores afirmaram haver um intercâmbio entre a fundação e a escola, tanto por meio de projetos como por troca de informações dos alunos. Para participar da fundação, é necessária a matrícula na escola.

Em geral, o contato com a escola dá-se de maneira bastante superficial, assim como visto na ONG anterior. A organização não busca influenciar as práticas educativas da escola nem a sua gestão - ela não faz parte da comunidade, como afirma. Inexiste a troca de idéias entre as duas instituições educacionais (escola e ONG). Apesar das informações dos monitores, pode-se verificar que os projetos não são desenvolvidos em conjunto, eles são levados prontos para a escola e a relação entre escola-ONG resume-se à troca de fichas de alunos.

A intenção por parte da ONG em auxiliar a escola a melhorar parece ser nula, seu trabalho é paralelo. Isso pode ser um equívoco, pois como uma outra instância educativa, as ONGs deveriam manter um relacionamento mais estreito com a escola. Se não houver a intenção de contribuir para melhorar o sistema público de ensino e trazer melhorias com autonomia, as ONGs estarão sempre trabalhando individualmente e não para a coletividade. Se suas propostas educativas nunca chegarem à escola e a um número muito maior de alunos, o trabalho destas ONGs certamente estará incompleto e a escola pública vai permanecer sendo criticada sem receber ajuda. Obviamente que, se as melhorias na escola fossem todas implantadas e chegássemos um dia a ter um sistema público de qualidade, talvez a razão para a existência de muitas ONGs desapareceria e algumas parecem não estar dispostas a isso.

\subsubsection{TRABALHO COM A LEITURA}

A leitura é trabalhada concomitantemente à produção escrita. Os educadores selecionam livros que acreditam ser adequados à faixa etária de cada turma. Rotineiramente, 
em quase todos os encontros (que são diários), há a leitura de uma parte ou de um capítulo de um livro. Às vezes, o educador lê em voz alta, outras são os próprios educandos que se dispõem a ler. Nem sempre são feitas discussões sobre o livro que está sendo lido ou foi finalizado. A educadora Daisy afirmou que quando se lê apenas como forma de prazer, não há discussões, porém, quando o livro se insere em um projeto específico, ela cria um espaço para discussão.

Aqui questionamos a posição de Daisy, pois sabemos que o prazer não exclui a discussão nem a busca de compreensão! Se, como afirmamos, cabe ao leitor atribuir significado ao texto para que este "enriqueça ou transforme sua existência de vida" (Coelho, 2002, p.32), há intrinsecamente uma busca de compreensão. Acreditamos que o que Daisy quis dizer está relacionado à importância do prazer desinteressado que comentamos anteriormente, o prazer emocional. Porém, ao posicionar-se desta forma, ela parece dividir a leitura em duas categorias: a do prazer e a do projeto específico, como se a leitura inserida no "projeto" não pudesse ser também prazerosa, e a leitura por prazer se opusesse ao conhecimento ou à ação. A leitura, como discutimos no capítulo 3, carrega-se de significado quando, depois de experimentar o prazer emocional de uma obra, caminha em direção ao ato de reflexão e ao prazer estético. Se Daisy divide a leitura em dois tipos, a primeira, "leitura por prazer", permanecerá somente no prazer emocional e a segunda, "leitura do projeto", permanecerá como "obrigação/trabalho". Assim, há evidências de que, a partir deste ponto de vista, nenhum dos tipos de leitura contribuirá eficazmente para o enriquecimento humano e intelectual dos alunos, e muito menos para a sedução dos alunos para o universo da palavra escrita.

Daisy complementou que, durante as seções de leitura, os educadores não forçam as crianças a lerem, mas procuram atraí-las para a atividade. Porém, se encontram resistência, permitem que a criança não participe, evitando, de acordo com ela, causar um bloqueio ainda maior em relação ao ato de ler. Daisy afirmou, no entanto, que nunca desiste de tentar criar um "hábito de leitura" e a leitura por prazer, mas que isto não tem sido um trabalho fácil, nem tem obtido $100 \%$ de sucesso. É possível que uma das causas do fracasso em constituir leitores esteja nas práticas educativas da educadora ao separar e rotular os "tipos de leitura". 


\subsection{ONG 3}

Decidimos visitar esta ONG por ser uma organização já bastante reconhecida por seu trabalho e ter sido uma das vencedoras do prêmio Itaú - Unicef.

Segundo o site da ONG, seu intuito é funcionar como um laboratório de práticas pedagógicas, "no qual são testados e desenvolvidos programas para fazer da escola uma extensão da comunidade e da comunidade uma extensão da escola, criando, assim um grande espaço educativo: o bairro-escola".

Nossa visita foi realizada na sede da ONG, em um pequeno pátio coberto que funciona como uma copa e por onde passam muitas pessoas. Em função do local, a entrevista realizada neste dia sofreu diversas interrupções de outros funcionários da instituição (três vezes), informando algo ou simplesmente parando para conversar, e de um grupo de publicitários buscando um acordo com os grafiteiros da organização para um projeto.

Foi Marta, coordenadora que trabalha com contatos, parceiros, eventos e marketing, quem nos atendeu. Antes de conseguirmos marcar este primeiro encontro foi preciso telefonar diversas vezes, e, no decorrer da entrevista, tornaram-se ainda mais perceptíveis a agitação e os inúmeros compromissos da entrevistada. Duas vezes, ela se perdeu nas respostas dadas, começando a responder e continuando com um discurso já decorado sobre a instituição. Sentimos mais uma vez a dificuldade em estabelecer contato com algumas ONGs e a disponibilidade dos seus coordenadores em atender os pesquisadores.

Há quatro anos e meio na ONG, Marta mostrou-se bastante inteirada sobre as atividades e informações gerais da instituição e foi, apesar da demora em nos atender, bastante atenciosa no decorrer da entrevista realizada com inúmeras interrupções.

\subsubsection{HISTÓRICO, PROJETO PEDAGÓGICO E ESTRUTURA}

\subsubsection{HISTÓRICO}

Esta terceira ONG, com foco em educação comunitária, foi criada em 1997 por um famoso jornalista. 
O projeto teve início com um site, criado e mantido por jovens provenientes de escolas públicas e particulares, cujo objetivo era estudar a forma com que os conteúdos de Direitos Humanos poderiam se encaixar no currículo escolar. A partir da redação deste site, outros projetos que giravam em torno da questão educativa e comunicativa foram surgindo e, assim, o site transformou-se em uma ONG. Todas as atividades da instituição baseiam-se no conceito de Bairro-Escola que tem o intuito de, segundo seu site:

integrar os agentes sociais e a comunidade num amplo espaço educativo. Cidades transformadas em comunidades educativas, ampliando as possibilidades de aprendizagem e melhorando a qualidade de vida urbana. Cafés, praças, becos, restaurantes, discotecas, livrarias, entre outros, transformados em salas de aula, construindo assim uma inter-relação com as escolas.

\subsubsection{PARCERIAS}

Para Marta, uma ONG é um grupo de pessoas da sociedade civil que se reúne com o mesmo ideal: criar formas de desenvolvimento da comunidade, por meio de sua forma de pensar.

A ONG 3 tem seu foco na educação. Segundo Marta, cada ONG, dentro de sua especialidade, propõe-se a fazer um trabalho que acha que não está sendo feito, a fim de suprir uma carência deixada pelo poder público em benefício da sociedade.

No caso desta ONG, suas parcerias são financeiras para a manutenção da própria organização e também institucionais, por meio de fornecimento de material e colaboração de voluntários (por exemplo, na área de publicidade e assessoria de imprensa). No entanto, apesar destas parcerias, a coordenadora afirma que a organização não se submete ao julgo e vontade de seus financiadores, sendo a idéia de responsabilidade social e a boa imagem da empresa suficientes para angariar a adesão de seus parceiros.

A cobrança de suas parcerias restringe-se à prestação de contas (contabilidade) e à sua credibilidade. Em geral, seus patrocinadores não acompanham os projetos, mas interessam-se pelos resultados finais. De acordo com Marta, uma vez que a ONG 3 possui uma política e 
uma proposta bem definida, seus parceiros são parceiros porque aceitam sua proposta de trabalho, pelo conceito que vem desenvolvendo e que pretendem multiplicar.

Ao serem perguntadas sobre a dependência dos parceiros financeiros, todas as ONGs afirmaram que esta dependência não se refletia nas decisões tomadas pelas organizações e nem no andamento dos projetos. Na realidade, isto parece uma questão um pouco mais complicada do que as ONGs querem nos fazer crer. Evidentemente que há uma obrigação em apresentar resultados positivos das atividades propostas, o que, por um lado, é algo bom, porém é complicado permanecer neutros quando se depende economicamente de outras instâncias que possuem seus próprios interesses. Na ONG 1, o grupo financeiro que dava apoio era também quem estava fornecendo um curso de formação de educadores. Até que ponto então os parceiros financeiros realmente não direcionam ou influenciam as ONGs? Este é um assunto instigante que poderá ser tema de outras pesquisas e que merece ser aprofundado.

\subsubsection{PROJETO PEDAGÓGICO E METODOLOGIA}

A base da proposta pedagógica da ONG, de acordo com Marta, vem de Anísio Teixeira, John Due e Freinet. Segundo a coordenadora, a ONG 3 não inventa nada, mas se utiliza de idéias disseminadas pelo mundo (Estados Unidos, Índia, as cidades-educadoras da Espanha) e que acredita serem úteis e adequadas para o nosso sistema, nas condições em que nos encontramos no Brasil. Desse modo, norteiam-se por diversas teorias e exemplos práticos para realizar suas atividades.

A ONG não trabalha em paralelismo com o conteúdo da escola, o trabalho pedagógico é feito por meio das diferentes oficinas nas quais se estudam as matérias clássicas da escola, como matemática, ciências, português etc., de modo prático, ou seja, em atividades como a de robótica. Assim sendo, segundo Marta, "as atividades são realizadas a partir de um aprendizado e de uma realização concreta e não de um conteúdo decorado para passar na prova”.

A ONG 3 fornece inúmeras oficinas para os educandos, bem como círculo de discussões e palestras. No dia em que estivemos lá, o Doutor Dráuzio Varella estava presente dando uma palestra e conversando com os jovens sobre o uso de drogas e narcóticos. 
O planejamento das atividades é feito anualmente e começa a partir de outubro do ano anterior. A ONG já possui uma estrutura básica de trabalho e, a cada ano, há mudança de pequenos detalhes. Os coordenadores da ONG decidem o quê, como e com quem pretendem trabalhar.

No início de cada ano, apresentam uma grade horária para os educandos escolherem livremente as atividades das quais participarão: há cursos de robótica, tênis, basquete, design / desenho animado no computador, atividades circenses, leitura e contação de histórias, artes. Há, ainda, a produção de um jornal pelas crianças e curso de fotografia.

As atividades acontecem na praça, no beco, na rua, em salas, de maneira que, para a ONG, qualquer espaço é um espaço educacional.

Há aulas de culinária em um buffet da região e aulas de barman em um bar. Ao espalhar as atividades pelo bairro, conscientizam as crianças e jovens de que nem sempre o aprendizado se dá em uma sala de aula.

O conteúdo a ser trabalhado nas diversas oficinas e aulas não é decidido somente pelo educador, há uma diretoria pedagógica composta por coordenadores de áreas. É um planejamento conjunto feito dentro da proposta principal da ONG de incentivar a criatividade, a expressão, a comunicação. As reuniões entre diretores, coordenadores e educadores ocorrem semanalmente, de maneira a permitir que todos fiquem inteirados do que está sendo trabalhado nas diversas oficinas oferecidas pela organização.

Por trás do trabalho da ONG 3, há toda uma teoria dos bairros-escolas que embasa suas ações e direciona a organização para certas metas. Possuem também um livro, escrito por outro famoso jornalista, que conta a história da ONG e as idéias com as quais trabalha. Porém, não apresentaram um projeto pedagógico ou um documento que explicasse de forma teórica suas idéias e apresentasse as etapas do processo para atingirem seus objetivos. 


\subsubsection{AVALIAÇÃO}

Durante três anos, os coordenadores discutiram quais os índices que deviam medir para avaliar o impacto de suas ações na vida dos educandos e no seu desempenho escolar, sem, no entanto, chegarem a um denominador comum. Junto a técnicos discutiram meios possíveis de avaliar seus programas e, segundo Marta, chegaram à conclusão de que seria muito difícil medir "felicidade", ou melhoria da qualidade de vida.

Alguns projetos, como as oficinas de informática e de rádio, possuem avaliações individuais a partir de alguns dados. Neste ponto, Marta não foi muito clara, deixando de explicar detalhadamente como é realizada tal avaliação e que dados são considerados para chegar-se a conclusões.

No entanto, realizam acompanhamento dos educandos na escola e na sua vida familiar. Marta defendeu a importância de trabalhar qualitativamente e não quantitativamente, de maneira a fundamentar a avaliação da ONG a partir deste acompanhamento da vida diária das crianças e jovens atendidos.

Sem dados concretos que apontem a melhora do desenvolvimento humano e intelectual, a ONG possui dados de observações de seus educandos e famílias. Segundo Marta, são depoimentos sobre a melhoria da qualidade de vida ("felicidade") de alunos da rede pública que por lá passaram e continuaram seus estudos na faculdade.

Quando perguntada se havia algum meio de detectar a influência das atividades promovidas pela ONG na vida das crianças e jovens que delas participam, Marta contou que uma das formas de perceber a positividade das ações da organização é o interesse que eles demonstram ao vir todos os dias para a ONG 3, sendo que o castigo / punição que alguns pais dão para seus filhos, quando estes não se comportam bem, é não ir à ONG. Segundo a coordenadora, isto se deve ao fato de que os educandos estão lá por escolha própria, e participam de atividades escolhidas livremente por eles mesmos. A proposta da ONG é fornecer um leque diversificado de oportunidades para que os educandos possam desenvolver suas habilidades, uma vez que ao descobrir qual é a sua habilidade, torna-se mais fácil traçar um plano de vida, determinar metas, aumentar a auto-estima. 
Resumindo, não há também nesta ONG, como nas anteriores, um sistema de avaliação concreto e eficaz que realmente aponte os resultados dos trabalhos da organização. É certo que depoimentos dos participantes são fundamentais, porém não representam o todo. A importância de um sistema de avaliação está no fato dele promover algumas respostas e mostrar se realmente uma atividade está colaborando ou não para o desenvolvimento cognitivo e pessoal dos alunos.

\subsubsection{FUNCIONAMENTO DA ONG}

Como nas ONGs visitadas anteriormente, nesta organização os participantes tomam parte das atividades propostas no período em que não estão na escola. Assim, quem estuda de manhã freqüenta a ONG à tarde e quem estuda à tarde freqüenta a ONG pela manhã.

Os jovens não são divididos em faixas etárias, trabalhando todos juntos dos 16 aos 22 anos. No caso das crianças, dependendo do tipo de atividade, há uma divisão que vai dos 4 aos 6 anos, depois dos 7 aos 10, dos 10 aos 13 e, finalmente, dos 14 aos 16 anos. Porém a organização afirma pretender misturar mais as faixas etárias.

Todos os educandos que participam das oficinas oferecidas pela ONG precisam estar matriculados na rede oficial de ensino, pois, segundo Marta, a organização não é uma escola.

A ONG não possui número de vagas limitadas, conseqüentemente, não possui um critério para a participação das crianças e jovens em seus projetos. Em 2004, o número de crianças atendidas ficou em torno de 300, em 2005, foram 200.

A ONG 3 não faz divulgação no bairro para atrair um número maior de participantes, pois, estando na região há 8 anos, já se tornou bastante conhecida. No entanto, possui parcerias com todas as escolas da região, buscando trabalhar não só com a criança, mas também com seus pais, com a escola e com a comunidade, uma vez que percebem a criança como um sujeito inserido em um bairro, em uma comunidade. Dessas crianças, $80 \%$ moram na favela que existe na Rua Fidalga e $20 \%$ são crianças de outros bairros cujos pais trabalham nesta região e não conseguiram vagas nas escolas da periferia de onde provêm. Há ainda uma porcentagem menor de crianças provenientes de um albergue da região. 
No primeiro ano de existência, a ONG começou a trabalhar com 19 crianças e, a cada ano, este número foi aumentando, bem como a própria organização que buscou criar novas oficinas e atividades para comportar o público que vinha procurá-la.

O projeto proposto pela ONG existe no bairro de Vila Madalena como um modelo para outros bairros, não se propondo a expandir-se para outras localidades. Possuem, no entanto, algumas ações na favela Heliópolis, na favela Paraisópolis, no Jardim Conceição, bairro periférico de Osasco, e em Boa Vista, capital de Rondônia.

\subsubsection{REGISTRO DE PRESENÇA}

Nesta ONG, não é realizada uma chamada, como ocorre na escola, mas há o controle de presença pelo educador a partir da observação. Se um número muito grande de faltas é percebido pelo educador, a organização entra em contato com a família para saber os motivos das ausências.

\subsubsection{EDUCADORES E VOLUNTÁRIOS}

Todos os educadores da ONG são prestadores de serviço que recebem por hora-aula, e são graduados também em algum curso superior: pedagogia, artes plásticas, arte-educação, psicologia, comunicação, engenharia, direito. No total, a ONG possui 85 educadores. Na área de educação, há um voluntário de vídeo que trabalha junto com o educador da "Oficina de Vídeo" e outro voluntário na área de fotografia.

\subsubsection{ESTRUTURA}

Localizada na Vila Madalena, um bairro de classe média alta da zona Oeste de São Paulo e considerada pela UNESCO uma referência mundial em educação, a ONG possui cinco espaços na região: a sede (financeiro, administrativo, diretoria), um grande galpão com uma sala de cursinho pré-vestibular e uma de informática e robótica, uma casa, chamada “casa das crianças", uma praça e um beco, revitalizados pela própria instituição, e um Café. Todos estes espaços atenderam, em 2004, 780 jovens e crianças e um público indireto de 12 mil pessoas por ano nas atividades promovidas pela ONG espalhadas pelo bairro. 
Segundo Marta, a escolha da região deveu-se a uma pesquisa prévia dos moradores do bairro. Observando que neste havia um grande número de artistas, produtores de cinema, arquitetos e designers, os fundadores da ONG chegaram à conclusão de que este seria um espaço ideal, pois seus moradores estariam mais abertos e propensos a aceitar e entender as intervenções urbanas e as mudanças que a ONG promoveria nos arredores: desde a grafitagem e decoração de muros, passando pelas atividades educativas propostas e realizadas em vários espaços diferentes do bairro, até a recuperação de espaços degradados.

Ao ouvir esta explicação, contestamos se um bairro de periferia também não estaria aberto a essas intervenções. Por que não? Pelo que foi possível observar dos participantes de diversos projetos sociais, as famílias atendidas, bem como as comunidades nas quais estão inseridas, sempre se mostraram bastante abertas às propostas que vêm das inúmeras ONGs espalhadas pelo país. Questionamos por que um projeto que se preocupa com os mais necessitados e focaliza a escola pública como alvo de intervenções está localizado em um bairro de classe média alta. Seria uma questão de infraestrutura que a periferia eventualmente não possui, inviabilizando-a para o projeto Bairro-Escola? Mas se qualquer espaço é um espaço de aprendizagem, segundo a ONG, por que não um bairro periférico?

\subsubsection{BIBLIOTECA}

A ONG ainda estava construindo um espaço para abrigar uma biblioteca no momento da entrevista.

\subsubsection{PROJETOS - OBSERVAÇÃO DE UMA ATIVIDADE}

Na segunda visita à ONG 3, participamos de um encontro do grupo de crianças de 4 a 7 anos na "Casa das crianças". Para nossa surpresa, o que observamos foi algo muito diferente do que esperávamos a partir da nossa conversa com Marta e do conceito que havíamos formado da organização.

Em cada dia da semana, as crianças possuem uma atividade diferente, entre elas: circo, música, educação ambiental, tênis e o kid's net (computação para crianças), que observamos. 
A "Casa das crianças" é um sobrado espaçoso e bem cuidado. No piso térreo, possui um hall de entrada com sofás e murais de informação, uma cozinha, uma copa onde os educandos lancham, uma sala de computação (na qual havia muitos jovens que utilizavam os computadores enquanto esperavam o início de suas atividades) e banheiros. No segundo andar, há um terraço, um laboratório de fotografia, uma sala de educadores e três salas para atividades, duas com mesas e cadeiras dispostas tal qual uma sala de reuniões e uma só com uma estante de livros e algumas almofadas espalhadas sobre um tapete.

Antes do início das atividades conversamos com algumas crianças que esperavam pela educadora. O único menino da turma, Luis, 7 anos, não quis conversar, mantendo-se calado e nos observando. Luis alegava estar com sono e dizia que não queria ter vindo à ONG. Quando a educadora chegou, foi logo nos avisando que ele era um "garoto-problema" e muito indisciplinado, criticando-o em sua presença, situação bastante semelhante às que vivenciamos nas escolas públicas onde fizemos estágio: a professora criticava duramente seus educandos para a estagiária / pesquisadora na frente das próprias crianças, afetando bastante sua auto-estima.

A educadora, Cristina, aposentada, na verdade não era educadora e sim "a pessoa responsável pela turma”. Esperávamos encontrar uma educadora, porém ficamos sabendo, para nossa surpresa, que Cristina não era graduada na área de educação, nem possuía experiência prévia no campo.

Cristina participava do programa "Old net" (Internet para idosos), porém quando o programa terminou, não querendo se desvincular das atividades da ONG, conseguiu este espaço para trabalhar voluntariamente. Ela era uma senhora de mais ou menos 70 anos, bastante vigorosa e com uma séria preocupação com o controle de tudo: das crianças, do tempo e do material utilizado. Demonstrou estar muito feliz em poder continuar na ONG, e teceu inúmeros elogios à organização e ao seu fundador. Ao mostrar-me as instalações e os materiais disponíveis, ela mesma ficou encantada, perguntando-se quando aquelas crianças teriam acesso a tudo aquilo se não fosse pela ONG.

Junto com Cristina, vieram mais duas monitoras, Helena e Daniela. Helena também é uma ex-educanda da ONG que, tendo participado da oficina de rádio e mostrado um bom desempenho, foi convidada pela organização para trabalhar como monitora dos pequenos, 
recebendo para isso uma bolsa-auxílio. Helena ainda não tinha entrado na faculdade, mas prestaria o vestibular no ano de 2006. Daniela, por sua vez, é moradora do bairro e estava no $1^{\mathrm{o}}$ ano da faculdade de Nutrição.

Nenhuma das três monitoras está diretamente ligada ao campo da educação ou possui fundamentos teóricos consistentes sobre a área. Não ficamos sabendo, no entanto, se passaram por alguma capacitação antes de monitorarem as crianças.

Quando o grupo todo estava reunido, as três monitoras e 8 crianças (7 meninas e 1 menino) foram para uma sala sem mesas.

\subsubsection{Leitura, desenho livre e Kid's net}

Dentro desta sala, havia um tapete, dois almofadões, duas cadeiras, uma pilha de enciclopédias e uma grande estante com livros. Na parte inferior da estante havia revistas e gibis, na prateleira logo acima, livros de literatura infantil e juvenil e alguns vídeos infantis. Nas outras prateleiras, havia mais livros infantis e juvenis e depois alguns livros didáticos.

Ao chegarem à sala, sentaram todos no chão. Algumas crianças pegaram uns livros que estavam em um canto, e começaram a folheá-los, olhando, sobretudo, as ilustrações. Quando Cristina perguntou para as crianças se elas gostariam de ler uma história juntas, imediatamente todas responderam que não. Disseram que era chato ouvir histórias e que preferiam desenhar.

Fomos com a intenção de observar uma atividade de leitura, no entanto, as voluntárias, ao ouvir das crianças que não queriam ler, distribuíram uma folha em uma prancheta individual para cada criança e colocaram caixas de lápis de cor, canetinhas e giz de cera no meio do grupo. As crianças ficaram desenhando no chão, portanto, numa postura não muito adequada.

A abordagem das responsáveis pela turma foi bastante falha no que se refere a práticas de leitura. Não houve em nenhum momento a tentativa de inserir a leitura de forma significativa ou uma proposta de leitura que despertasse o interesse e/ou seduzisse as crianças para o livro. Elas simplesmente perguntaram: "Vocês querem ler?" e, naturalmente, não 
tendo o hábito nem acesso a materiais escritos, as crianças responderam prontamente "não", e não houve mais nenhum questionamento. Afirmamos novamente que o processo de constituição de leitores precisa passar pelo momento de sedução e do prazer emocional que, em geral, surge de um reconhecimento de si mesmo naquilo que se lê. Se inserida de forma significativa, a leitura seria, para estas crianças, uma atividade prazerosa e catártica. Se as responsáveis tivessem trazido a leitura com uma encenação, ou com uma conversa introdutória sobre o assunto da leitura (que necessariamente deveria se relacionar com as crianças), sem perguntar “vamos ler?", a atividade poderia ter sido bem sucedida.

A atividade então virou desenho livre, sem direcionamento, apenas supervisionada pelas monitoras.

Do meio para o fim da atividade, Renata, uma menina de 5 anos, pegou um livro da Cinderela e começou a copiar as letras que via no livro, imitando as palavras.

Ao olhar o relógio depois de 45 minutos de desenho, Cristina informou às crianças que agora iriam mudar de atividade e brincar com massinhas de modelar. Apressou as crianças para terminarem seus desenhos e disse a Renata que parasse de copiar as letras porque iriam brincar de massinha.

A atitude de Cristina foi inapropriada e faltou sensibilidade educativa por parte da voluntária, pois Renata estava muito interessada no que estava fazendo, familiarizando-se com as letras, com o próprio objeto-livro. Uma vez que ainda não era alfabetizada, aquele momento era importante para a menina, que provavelmente não possuía muito contato com materiais escritos.

Renata aceitou deixar o livro de lado, após Cristina prometer que mais tarde ela poderia continuar o que estava fazendo.

Assim, Cristina trouxe algumas caixas de massinha de modelar e disse para as crianças que elas poderiam fazer o que quisessem, sem nenhuma direção ou finalidade, e ressaltou durante toda a atividade que as crianças não deveriam misturar as massinhas de cores diferentes, pois a massinha seria reutilizada em outra ocasião. Lembrou também que 
não deveriam desperdiçar material. Assim cada criança fez algo diferente: bonecos, sorvetes, bolinhas, sol, árvore, comidas etc. Depois de pronto, as monitoras tiraram fotografias.

Ao fim da atividade com a massa de modelar, as crianças desceram até a copa para tomar um lanche: suco de laranja, mamão em pedaços e pão com manteiga.

Durante o lanche, percebemos que Renata havia descido com o livro da Cinderela debaixo do braço, provavelmente esperando pelo momento de retornar à sua cópia. O que não foi possível, pois logo após o lanche fomos até o núcleo de comunicação, um prédio ao lado da "Casa das crianças" que possui um amplo e bem iluminado espaço com 10 computadores para a oficina de computação: "Kid's net".

Neste espaço ocorrem as oficinas de computação, a "Kid’s net" para as crianças e a "Old net" para os idosos.

Cada criança sentou-se em frente a um microcomputador para desenhar livremente no programa PowerPoint da Microsoft. Após completarem seus desenhos, com o auxílio das monitoras, cada criança pode imprimir o seu trabalho e levá-lo para casa.

\subsubsection{BREVE ANÁLISE DAS ATIVIDADES}

De tudo o que vimos, ficou evidente a falta de direcionamento e propósito das atividades e, principalmente, a falta de uma preocupação pedagógica. As voluntárias não possuíam nenhum fundamento teórico e nem ao menos sensibilidade para entender as necessidades de aprendizagem das crianças. Não houve, nesta atividade, um desenvolvimento cognitivo e significativo - foram 45 minutos de desenho...

Nesta ONG, tivemos restrições (e decepção) pela maneira por meio da qual as atividades foram realizadas. Quando fizemos a primeira visita e entrevistamos Marta (a coordenadora), ela nos informou que os grupos eram monitorados por educadores contratados, formados em suas respectivas áreas de conhecimento, mas não foi o que observamos. Talvez nas aulas de artes, inglês, tênis, robótica isto efetivamente ocorra. 
As monitoras não demonstraram preparo nem organização para trabalhar com as crianças, simplesmente decidiram que seria dia de massa de modelar. Não criaram uma atividade que fosse significativa, por meio das quais as crianças pudessem aprender alguma coisa, ou lidar com seus sentimentos. Não houve uma atividade direcionada, com algum objetivo. Sabemos que mesmo a massa de modelar e o desenho podem ser inseridos de maneira significativa.

Grande parte das reclamações de alunos a respeito do trabalho feito na escola é que eles não entendem o porquê, os objetivos daquilo que estão fazendo. Ocorreu o mesmo na ONG.

O tratamento dispensado às crianças, nesta $\mathrm{ONG}$, pareceu-nos semelhante ao de uma creche tradicional que se ocupa em "olhar as crianças" enquanto os pais estão trabalhando, ocupando-as de alguma forma, ou de qualquer forma, e não como um laboratório pedagógico de novas práticas de ensino.

Podemos estabelecer um paralelo com propostas de atividades de leitura em que os educadores acreditam que, colocando as crianças em contato com os objetos-livros, é o suficiente para que se tornem leitoras. Certamente, as crianças poderiam atingir alguma melhora no seu desenvolvimento cognitivo se guiadas e instruídas por um adulto. $\mathrm{O}$ acesso a materiais diversos é importante, mas não é suficiente.

\subsubsection{ONG, EDUCAÇÃO COMUNITÁRIA E ESCOLA PÚBLICA}

O conceito de educação comunitária, que permeia todas as atividades da ONG, surgiu a partir das experiências que a organização veio acumulando em oito anos de existência. Hoje, a coordenadora afirma ter certeza de que ou a escola (principalmente a pública) se abre para a comunidade ou ela está fadada a ser o que é: uma instituição que não alcança mais os seus objetivos de aprendizagem.

O conceito de Bairro-Escola é outro pilar da proposta da ONG. Tal conceito busca a integração de elementos que estão separados na sociedade e, portanto, não se relacionam. Assim, buscam unir educação, cultura, esporte e saúde em um mesmo bairro, fazendo com que os moradores conheçam e utilizem os equipamentos sociais que seu bairro fornece, desde 
bibliotecas públicas até clubes esportivos. A escola, na maioria das vezes, não utiliza estes equipamentos sociais já existentes em benefício do desenvolvimento de seus jovens. Segundo Marta, muitas vezes os próprios professores desconhecem, por exemplo, as bibliotecas comunitárias de sua região.

No ano de 2005, a ONG conseguiu atingir uma meta que sonhara desde a sua fundação: interferir nas políticas públicas de educação.

Tudo o que construíra, todos os resultados dos laboratórios pedagógicos com crianças e jovens deram origem a um curso destinado aos professores da rede pública, que, agora, estão sendo formados dentro do conceito de educadores comunitários. Primeiramente, o trabalho começou com professores da rede pública municipal de 18 escolas da região central da cidade de São Paulo. Agora, o curso sobre educação comunitária da ONG está fazendo parte de um curso mais amplo fornecido pela USP Leste para 350 diretores e gestores de escolas públicas, buscando com isso melhorar o ensino público, sua relação com o bairro e ajudar no desenvolvimento da qualidade do trabalho dos professores, tentando fazê-los rever a sua forma de atuação. No ano de 2006, segundo Marta, começariam um curso em parceria com a Unicamp, para 6.000 professores-alunos abrangendo toda a rede estadual de São Paulo.

A ONG acredita que a escola pública precisa mudar e para isso propõe o diálogo como forma de repensar a escola. Segundo Marta, os professores não possuem a oportunidade nem o tempo para pesquisar novas formas de intervenção pedagógica e experimentá-las, mas a ONG sim. Logo, o fundamental neste caso é a troca de idéias e informações.

Marta afirma que a ONG estabelece relação com as escolas (professores também) de onde provêm seus participantes. No ano passado, a organização capacitou dez escolas da região para utilizarem seus próprios laboratórios de informática, que estavam fechados por falta de habilitação por parte de professores e funcionários. Participaram deste projeto dois professores e dois alunos de cada escola, totalizando 40 pessoas. Estas intervenções realizadas nas escolas públicas surgem por interesse das próprias escolas que procuram a ONG para ajudá-las a resolver suas deficiências.

As crianças também levam para a escola as atividades promovidas pela ONG. 


\subsubsection{TRABALHO COM A LINGUAGEM E LEITURA}

Segundo a coordenadora, a comunicação e a expressão são o foco principal da ONG. Marta afirmou que a organização não ensina Língua Portuguesa, no sentido escolar, mas ensina por meio de oficinas e atividades de leitura, narração de histórias e criação de desenhos animados no computador e nas aulas de arte. A linguagem permeia todas as atividades. $\mathrm{Na}$ escolinha da praça, há oficinas de poesia que acontecem o ano todo. $\mathrm{Na}$ realidade, não há um projeto específico de leitura e as informações transmitidas foram evasivas, como na ONG 1.

A ONG ainda não possui uma biblioteca própria, mas estavam iniciando a construção de uma mais direcionada ao público infantil em parceria com a Faculdade de Belas Artes. O espaço já existe na escolinha da praça, onde funciona uma sala de leitura decorada com pufes e cadeiras. Após a conclusão da biblioteca, será ministrado um curso de formação de monitores para a utilização deste novo espaço como um espaço de lazer e aprendizado.

A ONG pretende auxiliar os professores da rede pública a utilizarem as bibliotecas do bairro, para que possam usufruir de um espaço de cultura já existente: fazendo leitura e contação de histórias, buscando despertar o prazer de ler e escrever. 


\subsection{ONG 4}

Ao procurar organizações sociais que trabalhassem com a temática da leitura, chegamos até a ONG 4 por meio do site da ABONG (Associação Brasileira de Organizações Não-Governamentais).

Fomos recebidos para uma entrevista com Joana, assistente de coordenação, há três anos na instituição e estudante de pedagogia da Universidade de São Paulo (USP). Joana mostrou-se disponível e bastante atenciosa durante toda a visita, apresentando todos os funcionários com carinho, desde a copeira até os coordenadores. Sua fala foi toda pontuada pelos conceitos do educador que dá o nome à $\mathrm{ONG}$, mostrando um conhecimento profundo acerca da base teórica de seu trabalho, mas, por vezes, parecendo ter decorado falas e as utilizando em momentos que julgamos desconectados do que estávamos discutindo ou conversando.

\subsubsection{HISTÓRICO, PROJETO PEDAGÓGICO E ESTRUTURA}

\subsubsection{HISTÓRICO}

De acordo com seu site, a ONG 4 "surgiu da convergência de uma série de idéias e iniciativas" , fundada em 1991 durante um encontro entre intelectuais da área da educação de diversos países, quando seu fundador estava palestrando na Universidade da Califórnia (UCLA).

No site da organização, pode-se ler que a importância da ONG é poder

proporcionar o encontro de pessoas e instituições que pesquisassem ou trabalhassem em torno dos mesmos princípios que fundamentam a pedagogia do seu fundador (...) e reunir pessoas que movidas pelos mesmos sonhos, pudessem aprofundar reflexões, melhorar suas práticas e se fortalecer na luta pela construção de um mundo mais feliz ${ }^{5}$.

Consta em seu site que

\footnotetext{
${ }^{5}$ Site da Organização.
} 
Hoje, a ONG 4, uma associação civil, sem fins lucrativos, constitui-se numa rede internacional de pessoas e instituições, com membros distribuídos em vinte e quatro países.

\subsubsection{PARCERIAS}

A ONG 4 se sustenta por meio das atividades e projetos que desenvolve recebendo recursos de parcerias para a manutenção do próprio trabalho. De acordo com Joana, estes trabalhos não são vendidos como mercadoria, e sim subsidiados por uma entidade propositora que procura a ONG 4 e a convida para estabelecer uma parceria.

No momento da entrevista, não havia cursos em andamento, somente desenvolvimento de projetos em parceria com instituições diversas, com secretarias de educação, bem como com o Ministério da Educação.

Nas parcerias há o propositor, o articulador político e o executor (no caso, a ONG 4), cada um destes três dá algo e, em contrapartida, estabelece-se uma parceria e uma iniciativa.

Nestas parcerias, há uma troca de idéias e um diálogo intenso, a fim de proporcionar que tanto um lado como o outro possam influenciar nas tomadas de decisão dentro do projeto que está sendo desenvolvido. Normalmente, o representante da ONG 4, junto com o representante do parceiro, forma um núcleo gestor, e é este núcleo que delibera sobre as ações a serem implementadas.

\subsubsection{PROJETO PEDAGÓGICO / METODOLOGIA: FOLDER DA ONG 4}

O conceito adotado pela ONG 4 de escola cidadã tem sua origem no movimento de educação popular e comunitária da década de 80, que lutava por uma educação para e pela cidadania. Segundo a ONG 4, este movimento influenciou a Constituição Federal de 1988, a qual incorporou algumas de suas principais reivindicações. No ano seguinte, o fundador da ONG 4 iniciou sua gestão em São Paulo, cuja marca mais significativa foi a proposta de uma “escola pública popular", que mais tarde passaria a chamar de Escola Cidadã. Essa escola tem como princípios ser estatal quanto ao financiamento, comunitária e democrática quanto à gestão e pública quanto à destinação. 


\section{Objetivos - de acordo com o folder da ONG 4}

O principal objetivo do Movimento Escola Cidadã é contribuir para a construção de uma nova cidadania, como espaço de organização da sociedade para a defesa de direitos conquistados e criação de novos, buscando a gestação de um novo espaço público de decisão não estatal com vistas à construção de uma sociedade radicalmente democrática. Para isso, o Movimento procura:

- Desenvolver estudos e pesquisas que contribuam para a formação de educadores e definição de políticas públicas educacionais;

- Oferecer formação inicial e continuada, presencial e a distância, aos educadores das redes municipais e estaduais de ensino e de movimentos populares, centrada em quatro eixos: princípios de convivência, gestão democrática, ciclos e avaliação dialógica e currículo;

- Participar e colaborar com os movimentos de luta pela melhoria da educação formal e informal, em todos os seus níveis;

- Assessorar e oferecer consultorias a órgãos governamentais e não-governamentais para a definição de sua política educacional;

- Realizar pesquisas e organizar publicações que contribuam para manter vivo e atualizado o legado de Paulo Freire, bem como oferecer subsídios para reflexões e práticas educativas;

- Organizar e participar de eventos nacionais e internacionais que promovam o encontro de pessoas, instituições, sistematização e fortalecimento de experiências em torno da educação formal e informal, referenciadas no legado de Paulo Freire.

\section{Projetos em andamento, segundo folder da ONG 4}

- Escola Cidadã: a construção do projeto político-pedagógico (2000-2002 acreditamos que o folder deve ser de 2002) - com duas escolas estaduais de São Paulo, município de Osasco, para a construção do projeto político-pedagógico a partir dos princípios filosóficos de Paulo Freire. Público beneficiário direto: 5 mil alunos e 160 educadores das escolas - apoio Instituto C\&A e Programa Itaú Social; 
- Plano Municipal de Educação - desenvolvido junto à SEMED de Marabá-PA para elaboração do Plano de Ação Pedagógica. Público beneficiário: a equipe técnica da Secretaria da Educação e todos os educadores e alunos da rede.

\subsubsection{AVALIAÇÃO}

Cada sede, sub-sede e núcleo de estudos (espalhados pelo Brasil e pelo mundo) são encarregados de avaliar os efeitos de suas ações, sem para isso existir um método ou um processo previamente estruturado.

Mais uma vez, não existe um sistema de avaliação, assim, não há como saber sobre os resultados de sua atuação e, portanto, não se sabe o que pode ser feito para melhorar e/ou mudar.

\subsubsection{FUNCIONAMENTO}

A ONG 4, buscando a troca de experiências e o aprofundamento das reflexões teóricas sobre educação, em suas diversas unidades organiza seminários, congressos, fóruns e cursos de formação de educadores. Inclui também um programa de Pós-Graduação.

A atuação da ONG 4 centra-se na educação de jovens e adultos e compreende as áreas: avaliação dialógica, custo-aluno, carta escolar e etnografia da escola, currículo da escola cidadã, ecopedagogia, educação de jovens e adultos, gestão escolar e convivência, informática aplicada à educação, planejamento socializado ascendente e projeto políticopedagógico da escola.

\subsubsection{REGISTRO DE PRESENÇA}

Cada sede, sub-sede e núcleo de estudos (espalhados pelo Brasil e pelo mundo) são encarregados de controlar a presença dos participantes em cada um dos cursos oferecidos, sobretudo os de alfabetização. 


\subsubsection{PROFISSIONAIS E VOLUNTÁRIOS}

A ONG conta com a participação de profisssionais especializados nas ciências da Educação. A maior parte tem formação em Pedagogia e Pós-Graduação na área. Não há voluntários.

\subsubsection{ESTRUTURA}

A ONG 4 localiza-se em um prédio de fachada mal conservada, bastante pichado e antigo no bairro de Alto de Pinheiros (região nobre de São Paulo). Ocupa três andares e algumas salas no nível da garagem. Além dos trabalhos de coordenação e administração, há a biblioteca original de Paulo Freire, que pode ser visitada. Há ainda uma área anexa (Casa da cidadania), que não foi por nós visitada, onde acontecem cursos e palestras.

As instalações são bastante simples, porém bem organizadas. Há pelo menos 30 funcionários trabalhando no prédio. Em uma das salas trabalha-se com software livre, buscando autonomia em relação ao monopólio instaurado pela Microsoft.

\subsubsection{BIBLIOTECA}

Há na ONG a biblioteca de seu fundador, que só pode ser consultada no local (sete mil volumes) e livros espalhados pelas salas da administração. Por não possuir um espaço físico próprio para os educandos, a ONG não possui uma biblioteca ou um espaço de leitura.

\subsubsection{PROJETOS}

Ao ser perguntada sobre os projetos principais do instituto, Joana afirmou que tudo que fazem é principal e singular: "buscando sempre a valorização do ser humano enquanto sujeito histórico e ativo no processo de sua própria vida e no processo de construção de um mundo mais justo". Mas, por fim, acabou destacando dois projetos de EJA (Educação de Jovens e Adultos) como foco principal do instituto: MOVA Brasil, em parceria com a Petrobrás (alfabetização de jovens e adultos) e o Projeto Memória, realizado junto com a Fundação Banco do Brasil. 
Há ainda muitos outros citados por Joana, como: Tecendo saber; Talher nacional Fome Zero; AP Guarulhos e mais um em Nova Iguaçu.

Joana enfatizou que todos os projetos da ONG 4 são pedagógicos, e potencialmente educativos, pois "sempre possuem uma dimensão formativa, por mais que, por vezes, possuam um viés mais administrativo". Segundo ela, não há como dissociar o técnico do pedagógico, o administrativo do pedagógico, uma vez que "educar é encharcar de sentido cada ato da vida cotidiana". Assim, os projetos procuram "encharcar" as ações de sentido para que tudo tenha uma função educativa.

Ela não soube informar quantos projetos há em andamento. Apesar de a ONG 4 não ser dividida em departamentos, os funcionários formam grupos entre si para trabalhar em diferentes projetos.

\subsubsection{MOVA}

O projeto MOVA acontece atualmente em cinco estados: Rio de Janeiro, Ceará, Bahia, Sergipe e Rio Grande do Norte. Cada um desses pólos educacionais possui um coordenador que representa a ONG 4.

A escolha desses estados foi realizada a partir da detecção do grupo gestor, que considerou que estas áreas apresentavam um grande déficit de alfabetização e que, portanto, precisavam de um projeto específico.

O trabalho de leitura da palavra é feito associado à leitura do mundo, na direção da intervenção social.

\subsubsection{FORMAÇÃO DE ALFABETIZADORES}

O foco principal da ONG 4 é a educação de jovens e adultos, no entanto, possuem algumas intervenções direcionadas ao público infantil, como o projeto "AP criança". Em geral, não trabalham diretamente com as crianças, mas com a formação do alfabetizador. 
Os cursos de formação de alfabetizadores, por vezes, ocorrem na Casa da cidadania e são fornecidos por educadores contratados. Dentro do projeto MOVA, as aulas de formação de alfabetizadores são todas ministradas em São Paulo; depois, cada formador retorna a seu pólo e multiplica o conhecimento, formando novos educadores em suas localidades. É importante que os formadores sejam da localidade onde ocorre a alfabetização, pois é necessário que o alfabetizador saiba ler o contexto local para poder relacioná-lo com o global depois.

\subsubsection{PROJETO BRASIL ALFABETIZADO}

No momento desta entrevista, estava em curso no estado de São Paulo apenas o projeto Brasil Alfabetizado. Porém, Joana afirmou não ter clareza quanto aos locais em que ocorre, citando apenas a existência de turmas de alfabetização em presídios, em parceria com a Funap, e outras em Ferraz de Vasconcelos e no Vale do Ribeira.

Por saber que o processo de leitura se inicia na alfabetização e não termina nela (após o domínio da leitura da palavra), os educandos que participam dos programas de alfabetização sempre dão continuidade a seus estudos após o término do curso, ou refazem o curso de alfabetização ministrado pela ONG, caso haja necessidade.

O público dos núcleos de alfabetização vem de comunidades carentes, a partir dos 14 e 15 anos.

\subsubsection{FOMENTO À PESQUISA}

Um dos objetivos principais da ONG 4 é o fomento a pesquisas que resultarão em intervenções diversas, como os vários projetos coordenados pela organização. Assim, buscam a manutenção de um diálogo com a realidade existente, em termos de transformação de mundo, intervenção social e demanda social. Desta forma, os programas nascem de uma demanda concreta, como por exemplo, a necessidade de alfabetização de jovens no nordeste brasileiro. Portanto, o fato de os projetos existirem já seria, segundo Joana, uma intervenção, por serem fruto de uma leitura do mundo. 


\subsubsection{MOVIMENTO DA ESCOLA CIDADÃ}

Com o intuito de ajudar a escola pública, a ONG 4 possui muitos programas, sendo o principal o Escola Cidadã. Este projeto volta-se, sobretudo, para a assessoria da gestão escolar, debates sobre avaliação, currículo e princípios de convivência, buscando desta forma a democratização do ensino.

O movimento da escola cidadã trabalha na perspectiva da ampliação da participação democrática, da cidadania democrática e da construção de uma escola pública construída pelo povo. Dentro deste movimento, há diversas iniciativas, como a assessoria prestada para os CEUs (Centros de Ensino Unificado da cidade de S.Paulo), para secretarias de ensino e para o Orçamento Participativo de Guarulhos.

A ONG 4 acredita muito na escola pública e em sua melhoria, e, sobretudo, que ela não pertence ao governo, mas sim ao cidadão, ao coletivo, enquanto cidadania coletiva que se mobiliza. Sua postura é acreditar no ensino público, investir e se debruçar sobre ele.

Joana ainda completou, com o seu conhecimento da teoria do fundador da ONG, que "só seremos protagonistas na medida em que os outros também o sejam e juntos formarmos um coletivo". Assim, a luta da ONG 4 se faz nesta perspectiva, que "encara a escola como um bem público e coletivo, que também possui uma dimensão que é individual, de cada um enquanto cidadão dentro do coletivo, porque sozinho não se faz revoluções”.

\subsubsection{ONG E ESCOLA PÚBLICA}

Joana não se sentiu confortável em fornecer uma visão institucional da ONG 4 sobre a escola pública, porém aceitou dar sua visão pessoal, que colocamos aqui como o depoimento de uma profissional que se identifica com a instituição na qual trabalha.

Assim, segundo ela, a ONG 4 valoriza a escola pública, vista como um bem público que depende do cidadão que dela faz parte, para construí-la e melhorá-la cada vez mais. A responsabilidade pela escola é do estado enquanto órgão público, mas é também do cidadão, 
pois educação é dever do estado, mas é também dever do cidadão. A escola é um espaço potencialmente transformador, mas sozinha não transforma o mundo.

Joana propõe alguns pontos para reflexão. Primeiramente, se falar de qualidade é falar de qualidade para $10 \%$ da população, isto, para ela, não pode ser considerado qualidade. Para Joana, há muitos erros na implantação da progressão continuada, mas um avanço precisa ser admitido: quem estava fora da escola, agora está dentro dela. A democratização do ensino se deu efetivamente, porém a escola não está sabendo o que fazer com esta população que historicamente não esteve nos bancos escolares, e que não possui o mesmo capital cultural que possuía a população com a qual a escola havia se acostumado. Assim, agora a escola lida com um outro público, com carências e necessidades específicas e diferentes das de outros tempos históricos. Esse público precisa ser considerado em sua singularidade e respeitado no seu saber de experiência. Portanto, enquanto a escola não atentar para estas questões, o progresso na qualidade do ensino será conflitante.

Um dos problemas que se refere à alfabetização e à leitura na escola, segundo Joana, é que o professor não acredita em si mesmo como sujeito da prática pedagógica e tampouco acredita no seu aluno como sujeito capaz de aprender. Na medida em que se acredita na sua própria capacidade e na de seu aluno, a leitura torna-se fácil. Segundo ela, o professor precisa se ver como criador da prática pedagógica e não como "piloto do livro didático" e enxergar o aluno como potencial sujeito histórico, igual a ele, no sentido humano do diálogo e do relacionamento.

Quando perguntada sobre o propósito de muitas ONGs que buscam suprir as carências da escola pública, Joana diz não acreditar em suprir carências, em assistencialismo e em generosidade falsa que forma dependentes, e sim em rever a estrutura. Neste sentido, uma ação emergencial e imediata tem de vir necessariamente acompanhada de uma ação mais estruturada, para que um dia, através da luta pela melhoria da escola pública, possa-se abandonar o emergencial e investir no estrutural.

Joana apresentou uma alta conscientização dos problemas e realidade do sistema público de ensino, passando a confiança de quem sabe sobre o que está falando, diferente de outras ONGs pesquisadas. 


\subsubsection{LINGUAGEM}

Segundo Joana, a linguagem permeia as atividades de alfabetização, uma vez que a alfabetização não se limita ao aprendizado da técnica de decodificação do código, mas consiste em um ciclo que abarca o ler o mundo e ler a palavra: lendo a palavra se lê o mundo, e lendo o mundo se lê a palavra. Assim, a prática de leitura com objetivo de formação estaria desde o princípio no trabalho de alfabetização. Dentro da perspectiva de leitura do mundo, muitos materiais se fazem potencialmente instrumentos para a leitura, ou seja, objetos para serem lidos. 


\subsection{ONG 5}

Esta ONG nos foi apresentada por uma professora entusiasta do método de trabalho Waldorf e que já a havia visitado anteriormente.

Nossa visita restringiu-se a uma visita guiada e organizada por uma funcionária, Karen, ex-educanda da organização e que mora na comunidade atendida por este projeto social. Foi interessante constatar que muitos dos funcionários desta ONG são ex-educandos.

Para participar desta visita, deve-se agendar, pagar uma pequena taxa e levar $1 \mathrm{Kg}$ de alimento. O grupo de visitantes constituía-se de uma professora universitária, uma aluna universitária de Terapia Ocupacional, dois novos funcionários da instituição (também exeducandos da ONG 5) e uma funcionária da prefeitura.

\subsubsection{HISTÓRICO, PROJETO PEDAGÓGICO E ESTRUTURA}

\subsubsection{HISTÓRICO}

Localizada dentro da favela de mesmo nome (zona sul da cidade de São Paulo), a associação surgiu quando uma pedagoga alemã, que trabalhava em uma escola Waldorf, em 1975, começou a receber crianças da rua e da favela em sua casa, proporcionando momentos de lazer educativo para aqueles que batiam em sua porta mendigando e pedindo comida.

A pedagoga sabia que só fornecer comida não traria benefícios a longo prazo e, pensando na importância de criar um espaço para aquelas crianças, onde pudessem brincar com segurança, começou a trazê-las para dentro de sua casa e para o seu quintal. A cada dia apareciam mais crianças e, então, a pedagoga começou a dar também reforço escolar. Uma das idéias centrais do trabalho da ONG está no desenvolvimento da capacidade criativa, na importância do tempo reservado para brincar e no aprimoramento da sensibilidade por meio das artes.

Numa tentativa de unir sua realidade profissional - lecionando para crianças ricas na escola Waldorf - e sua realidade pessoal - atendendo crianças pobres que freqüentavam sua 
casa - a pedagoga alemã trouxe seus alunos da escola para brincarem junto com as crianças da favela. Segundo nossa guia, foi uma experiência de troca muito rica, pois as crianças da escola sabiam muito sobre música e artes plásticas e buscaram ensinar as outras crianças, enquanto estas também lhes ensinaram diversas brincadeiras de rua.

\subsubsection{PARCERIAS}

Para financiar seu projeto, a pedagoga viajou pela Europa, principalmente Alemanha, em busca de apoio financeiro. Hoje a ONG 5 possui parceiros mantenedores alemães e brasileiros (10). Entre estes parceiros estão a Prefeitura da cidade de São Paulo, a Ação Criança e o Colégio Visconde de Porto Seguro. Possui também alguns parceiros de projetos específicos, entre estes estão muitas empresas, bem como o Unicef.

Segundo Karen, cerca de 50\% da verba da instituição é proveniente da Prefeitura de São Paulo, $20 \%$ são doações do exterior, $15 \%$ são doações de pessoas físicas e jurídicas que contribuem mensalmente, e o restante provém da venda de produtos produzidos pelos funcionários da associação.

Karen ressaltou que os produtos produzidos pelos educandos nas oficinas de reciclagem, artesanato e marcenaria não podem ser vendidos. Assim, tudo o que os educandos produzem, eles levam para suas casas, sendo colocado à venda somente aquilo que é fruto do trabalho de professores e funcionários.

Nas oficinas, há sempre dois espaços, um pedagógico e outro de produção.

\subsubsection{PROJETO PEDAGÓGICO / METODOLOGIA}

De acordo com o folder da organização, a missão da ONG é

promover o amor ao ser humano independente da nacionalidade, raça, religião, posição política e condições social e física, proporcionando oportunidades através da educação, cultura e saúde, principalmente para as pessoas não-privilegiadas se desenvolverem material, social e espiritualmente, estimulando-as a agir conscientemente, com liberdade e amor. 
Nossa guia ainda completou que o desenvolvimento do ser humano, segundo a ONG, passa por três pilares: educação, saúde e cultura - e que são desenvolvidos nos diversos projetos da organização.

A ONG busca também o desenvolvimento social e a urbanização da favela: fazendo mutirões para a canalização do córrego (a ONG financiou 75\% das despesas, com a promessa de que o governo municipal arcaria com os 25\% restantes; no entanto, a prefeitura não cumpriu com sua parte no acordo e a ONG acabou arcando com toda a despesa) e construção de áreas de lazer (playground, construído por meio de doações, e a quadra esportiva, construída com mão-de-obra dos próprios moradores), no interior da favela.

Constatamos novamente que não há um projeto pedagógico específico da organização. Afirmam usar o mesmo método e o embasamento teórico das escolas Waldorf, porém não possuíam um documento com etapas e objetivos educacionais.

\subsubsection{AVALIAÇÃO}

Karen não soube informar se há um método avaliativo das atividades promovidas pela ONG. Disse, no entanto, que os resultados podem ser confirmados ao andar pela comunidade e conversar com seus participantes. Mais uma vez, as ONGs mostram seus resultados de maneira informal, sem uma análise aprofundada dos resultados de suas atividades.

\subsubsection{FUNCIONAMENTO DA ONG}

\subsubsection{REGISTRO DE PRESENÇA}

A matrícula na rede oficial de ensino não é quesito obrigatório para a participação das crianças em idade escolar nos projetos da instituição, pois o fato de estar fora da escola reflete algum problema que a ONG vai buscar resolver junto com a família, encaminhando a criança para a escola. A demanda por vagas na instituição é muito grande, não há prérequisitos que favoreçam o ingresso de uma criança, dependendo apenas da lista de espera, ou seja, da ordem de chegada (é anotada, inclusive, a hora em que é feita a inscrição). 
Devido ao número limitado de vagas, a presença é controlada. Há um número máximo de faltas permitidas por criança, para evitar ociosidade. A ONG ainda precisa, segundo Karen, prestar contas à prefeitura, informando o número de refeições servidas por mês e a freqüência das crianças. Apesar de não serem uma escola, nossa guia informa que é preciso estabelecer certos critérios de seriedade, como a freqüência.

\subsubsection{PROFISSIONAIS E VOLUNTÁRIOS}

Hoje a ONG 5 atende cerca de 1100 crianças e jovens (na faixa dos 4 meses de idade até os 18 anos), com um quadro de 230 funcionários (sendo $70 \%$ do quadro composto por pessoas da comunidade) e 80 voluntários (sendo 60 brasileiros e 20 estrangeiros que vêm a São Paulo temporariamente por meio de um sistema de intercâmbio).

\subsubsection{ESTRUTURA}

Com o passar do tempo e o número crescente de crianças que apareciam em sua casa, a fundadora da ONG precisou procurar os pais destas crianças para tentar encontrar uma solução e obter ajuda com vistas a dar continuidade ao trabalho. Assim, em 1979, criaram uma escolinha que hoje é chamada de centro cultural, onde se deu uma primeira palestra. $\mathrm{O}$ centro cultural é na verdade a sede da associação e conta com um teatro, salas de aulas, setor administrativo, pátio, refeitório, cozinha e uma lojinha que vende os produtos produzidos pelos funcionários da instituição. Junto com este prédio, foi construído um ambulatório que funciona como um posto de saúde para os moradores, além de fornecer também atendimento psicológico.

$\mathrm{Na}$ favela onde se localiza a ONG, além do centro cultural / sede da organização e do ambulatório (um prédio de dois andares, bastante amplo, organizado e limpo), a ONG possui diversos espaços: uma biblioteca, uma oficina de marcenaria, uma oficina de papel reciclado, uma oficina de artesanato, uma padaria, uma creche e uma sala de informática.

A creche localiza-se em uma casa térrea com um pequeno espaço de playground nos fundos. Constitui-se de uma grande sala cor-de-rosa bem iluminada, com piso azulejado e 
móveis do tamanho das crianças (mesas, cadeiras, armários). Há também nesta casa uma cozinha onde são preparadas refeições para as crianças.

A oficina de papel reciclado localiza-se em outro prédio, junto com o laboratório de informática. A sala da oficina é bastante ampla e bem iluminada. Há diversas mesas grandes (altas e com o tampo amplo), do tipo que é utilizada por arquitetos, unidas de maneira a formar um "L". Ao redor destas, existem cadeiras altas para os educandos sentarem. Algumas peças produzidas pelos educandos estão expostas em uma estante de metal e um varal feito de barbantes cruza a sala de ponta a ponta, em um movimento de ida e volta, onde são pendurados pedaços de papel reciclado. No fundo da sala existe um tanque e muitas telas.

O laboratório de informática possui 15 computadores conectados à Internet. Um monitor permanece na sala o tempo todo auxiliando os usuários. Quando não há cursos, a sala fica aberta à disposição da comunidade. Os computadores estão dispostos na sala ao redor das paredes e a mesa do monitor fica no centro da sala.

A oficina de marcenaria está instalada em um amplo galpão totalmente equipado com aparelhos de corte, medida e lixamento. Há muito material encostado pelas paredes para ser utilizado pelos educandos e funcionários.

Não foi permitida a visita às oficinas de artesanato, tear e padaria.

A associação ainda possui um segundo núcleo, em outra favela da região. E um terceiro, denominado "Horizonte", a 17 km de São Paulo. Este terceiro núcleo surgiu a partir da compra de um terreno na região, adquirido com o intuito de receber as crianças das favelas atendidas, para brincarem e terem contato com a natureza. Porém, ao chegarem ao local, perceberam que as crianças daquela região possuíam carências iguais ou até maiores que as crianças que eles estavam levando para brincar e, assim, iniciaram-se os trabalhos neste novo núcleo.

A associação possui no "Horizonte" uma horta orgânica que abastece as três unidades. 


\subsubsection{BIBLIOTECA}

A biblioteca está instalada em uma casa de dois andares, localizada em um terreno mais elevado que o restante da favela, poderíamos dizer, sobre um morro. Há uma placa que indica a direção da biblioteca.

A porta de entrada é estreita e o espaço é um pouco restrito, seu acervo é relativamente grande e diverso (segundo Karen, a biblioteca possui aproximadamente 7000 livros), estando instalado em prateleiras de madeira, bastante próximas umas das outras, com os livros dispostos tal como em qualquer biblioteca.

Por sua vez, o acervo de literatura infantil e juvenil está disposto em estantes de metal não muito altas e com as capas viradas para frente, tal como encontramos as revistas em bancas de jornal. Consideramos muito interessante a organização deste espaço, permitindo às crianças um acesso mais fácil aos livros e também a visualização das capas e ilustrações que possuem um papel central nos livros infantis e, às vezes, determinante na escolha dos pequenos leitores.

Há também no centro da área que abriga a seção infantil e juvenil uma grande mesa coberta de livros didáticos e de temáticas históricas e geográficas. Tais livros estão dispostos em pilhas, de forma que a capa do livro que se encontra no topo fica exposta aos visitantes.

$\mathrm{Na}$ área de livros técnicos e de literatura dita "adulta", depois da última estante, há uma pequena mesa onde fica a responsável pela biblioteca, Lúcia. Sobre sua mesa há um computador conectado à internet que serve, entre outras coisas, para fazer consultas. Por mês, Lúcia afirma que ocorrem por volta de 1000 retiradas de livros. Ela não tinha certeza dos números, pois ainda não possuía um sistema que permitisse este controle - os livros ainda não estavam catalogados (só o acervo de literatura brasileira estava pronto) - e o controle existente é feito por meio de anotações em um caderno. De qualquer forma, Lúcia afirmou que o número de retiradas depende muito da época do ano, se os educandos estão ou não em período escolar ou em época de provas e trabalhos. 
Ainda segundo a responsável pelo espaço, a maioria dos usuários são alunos que vêm fazer pesquisas escolares. Ultimamente, tem aumentado o número de senhoras ( $3^{\mathrm{a}}$ idade) e moças que freqüentam a biblioteca. Elas normalmente retiram romances estrangeiros.

Quando perguntada sobre o número de pessoas que estão inscritas para retirar livros, Lúcia não soube dizer, mas afirmou que há dias em que chega a receber 60 inscrições. É possível retirar livros, com exceção dos livros didáticos.

No segundo andar do prédio da biblioteca, há um espaço grande que está sendo utilizado como academia de ginástica. Havia a intenção de utilizá-lo como um espaço de leitura, pois no primeiro andar não existem mesas ou cadeiras para quem pretende ler. No entanto, outros moradores acabaram ocupando o espaço para práticas esportivas, tocando música em uma altura razoável.

Segundo Karen, este mesmo espaço da academia, por vezes, é utilizado para festas nos finais de semana pela comunidade, já tendo ocorrido inclusive festas de casamento. Durante os dias de sábado, há um cursinho pré-vestibular neste espaço. Para nossa guia, é um espaço "multi-uso, de mil e uma utilidades".

A localização da biblioteca é excelente, bem no meio da comunidade e acessível a todos. O ambiente é muito amigável e, na medida do possível, bem organizado. Falta, no entanto, espaço para leitura e iluminação adequada para que a biblioteca seja ainda mais atraente e possa favorecer atividades de leitura.

\subsubsection{PROJETOS}

$\mathrm{Na}$ área da educação, a ONG possui as seguintes atividades: até os 7 anos, as crianças ficam na creche em período integral. Dos 7 aos 14 anos, elas passam a fazer parte do projeto "Gente jovem", ficando meio período na instituição e participando de atividades de reforço escolar (ajuda no dever de casa de história, geografia, português e matemática), artesanato, dança, pintura, música etc. (que não fazem parte do currículo da escola). Finalmente, dos 15 aos 18 anos, os jovens participam de oficinas de iniciação ao trabalho: marcenaria, corte e costura, tecelagem, bijuteria, reciclagem de papéis, reciclagem de móveis e padaria. 
Os cursos da área de educação fornecidos pela ONG são ministrados por profissionais qualificados na área de atuação correspondente ao conteúdo que ministram. Todos são contratados pela $\mathrm{ONG}$ e recebem pagamento por suas atividades.

Eventualmente, a associação promove palestras com médicos, pedagogos e outros profissionais liberais, abertas à comunidade, incentivando a discussão entre os moradores sobre aspectos importantes para a vida diária de todos.

No que concerne à área da cultura, o espaço do teatro é utilizado para apresentações diversas, como recitais de música, corais e saraus. Há ainda 70 oficinas culturais que acontecem nos três núcleos da Associação. Estas oficinas incluem cursos de línguas (considerados no âmbito da cultura e não da educação), música, dança, artesanato etc. As oficinas são gratuitas e ministradas por voluntários.

Já a área da saúde está concentrada no ambulatório que atende por volta de 3.000 pessoas por mês, onde os funcionários trabalham a partir da medicina antroposófica. $\mathrm{O}$ trabalho nesta área é feito em parceria com o posto de saúde local, que encaminha as pessoas para o ambulatório da associação. Há ainda uma parceria com uma farmácia homeopática que fornece os medicamentos a preço de custo para a instituição.

\subsubsection{ONG E ESCOLA PÚBLICA}

Segundo Karen, excetuando-se o reforço escolar, o conteúdo trabalhado na ONG não busca estabelecer uma relação direta e paralela com o que os alunos estudam na escola. Em geral, as educadoras procuram trabalhar juntamente com a escola, no entanto, Karen não soube dar detalhes, nem responder se possuem projetos em parceria com as escolas, limitando-se se a responder: "eu não sei em que pé está isto (relação entre a ONG e as escolas), mas eu sei também que não é uma coisa fácil. São muitas as escolas, muitas as crianças e poucas as educadoras, então, dificilmente a gente tem fôlego para isso”.

Ao ser perguntada sobre o reflexo do trabalho da ONG nas escolas públicas que as crianças freqüentam, Karen também não soube responder, comentando outro aspecto referente à diferença de metodologia e visão de mundo da ONG e da escola (o "lá fora"): 
Olha, da faixa etária dos 7 aos 18 anos, eu não sei te responder com precisão, mas posso te falar da creche. Por exemplo, na creche a criança fica aqui em período integral. Tá certo que não tem esse contato com outra escola, mas aí, a notícia que chega para a gente, é que na segunda-feira, as crianças sempre chegam mais, é, assim (querendo dizer animadas)... em sala, pelo fato de terem tido um contato maior dentro da própria casa, no final de semana (...) as educadoras também tentam trabalhar diretamente com os pais, explicando mais detalhadamente a pedagogia Waldorf, mas chega lá fora é outra realidade, é um mundo bem diferente. E eu acredito que não seja bem diferente com as outras faixas etárias.

Não há novamente, como nas ONGs 1 e 2, relação com a escola pública, nem ao menos troca de informação sobre os alunos. Ao contrário das outras ONGs, esta não tem como pré-requisito a matrícula na escola. Mais uma vez, não existe a preocupação em melhorar a escola pública ou auxiliá-la de algum modo.

\subsubsection{LINGUAGEM}

A ONG não possui uma oficina específica para leitura e trabalho com a linguagem. $\mathrm{O}$ pouco que se trabalha com esta questão restringe-se ao reforço escolar que, muitas vezes, ocorre na biblioteca.

Há um projeto da responsável pela biblioteca para o incentivo à leitura, porém focalizando a questão sob a perspectiva do reforço escolar. Segundo Karen, o projeto ainda está buscando voluntários.

Existia um curso de alfabetização de adultos ministrado por uma voluntária, ligado ao programa MOVA do governo. Todavia, por algum motivo, que Karen desconhece, o curso foi suspenso. 


\subsection{QUADRO COMPARATIVO DAS ONGs, ANÁllSE DOS DADOS E JUSTIFICATIVA PARA ESCOLHA DA ONG 6}

O que vimos e analisamos nessas visitas às cinco organizações foi muito boa vontade, mas também muito amadorismo. Em geral, percebemos em todas a intenção de procurar trazer melhorias de qualidade de vida para a população atendida, por meio da melhoria da educação dos seus alunos. Há, sem dúvida, boa intenção, mas falta muito fundamento teórico. Como analisado anteriormente, as concepções não são explicitadas e muitas têm dificuldade de apontar seus objetivos e os caminhos percorridos a fim de alcançá-los.

Nas ONGs, verificou-se a ausência de projetos pedagógicos e de sistemas de avaliação. A maior parte parece permanecer no que chamamos de atuação por "intuição" ou amadorismo, sem reflexão e direcionamento de suas atividades em busca do melhor desenvolvimento cognitivo e afetivo/pessoal dos seus educandos. Freqüentemente, quando questionadas sobre seu projeto pedagógico, afirmaram que o estão desenvolvendo. A preocupação com o projeto pedagógico e o estudo de práticas e das ciências da educação não parecem ser uma questão central para elas. As ONGs atuam sem base teórica, vão direto para a prática sem conceituação. Falta formação para que possam direcionar de maneira mais eficaz as suas atividades e práticas e, assim, contribuir realmente para a melhoria da educação de seus participantes.

O fato mais preocupante, no entanto, foi a ausência de ações compromissadas da maioria das ONGs objeto de nossa investigação (ONGs 1, 2 e 5) em relação à escola pública. A fraca ou inexistente atuação dessas ONGs junto às escolas mostra um desinteresse quanto à melhoria do sistema público de ensino, que não adiciona muito à sociedade e, principalmente, não a transforma.

Como afirmamos anteriormente, estas organizações não buscam influenciar as práticas educativas da escola nem a sua gestão e, por isso, mantêm-se à margem da comunidade. A falta de troca de idéias entre escola e ONG não ajuda a estabelecer melhorias. O trabalho paralelo das organizações pouco acrescenta para a coletividade, talvez acrescente somente individualmente, se é que isso ocorre com freqüência, visto que as organizações também não possuem um processo avaliativo para comprovar a melhora e/ou desenvolvimento cognitivo dos indivíduos participantes. Mais uma vez, afirmamos que se as 
propostas educativas da sociedade civil nunca chegarem à escola e a um número maior de alunos, o trabalho destas ONGs estará incompleto e a escola pública vai permanecer sendo criticada sem ajuda e sem ações/intervenções positivas.

Tendo em vista o quadro comparativo (Figura 02) que se segue, baseamos nele a nossa escolha pela ONG 6, que será apresentada no capítulo seguinte, por contemplar um projeto pedagógico (o que nenhuma das ONGs deste capítulo apresentou), possuir um sistema de avaliação, influenciar/atuar diretamente na escola, bem como por possuir um programa direcionado especificamente para a constituição de leitores e para o desenvolvimento do letramento. 


\begin{tabular}{|c|c|c|c|c|c|c|c|c|c|c|}
\hline & $\begin{array}{l}\text { Ano de } \\
\text { fundação }\end{array}$ & Fundador & $\begin{array}{l}\text { Projeto } \\
\text { Pedagógico }\end{array}$ & $\begin{array}{l}\text { Sistema de } \\
\text { Avaliação }\end{array}$ & Profissionais & Biblioteca & $\begin{array}{l}\text { Projeto } \\
\text { de } \\
\text { Leitura }\end{array}$ & $\begin{array}{l}\text { Relação com } \\
\text { a escola }\end{array}$ & $\begin{array}{l}\text { Abertura } \mathrm{p} / \\
\text { pesquisa }\end{array}$ & $\begin{array}{l}\text { Tipo de } \\
\text { ONG }\end{array}$ \\
\hline ONG 1 & 1992 & $\begin{array}{l}\text { Terapeutas } \\
\text { Florais }\end{array}$ & $\begin{array}{l}\text { Não - em } \\
\text { andamento }\end{array}$ & Não & Sim & Sim - ruim & Não & Fraca & Boa & $\begin{array}{l}\text { Interven- } \\
\text { ção }\end{array}$ \\
\hline ONG 2 & 1998 & Atletas & $\begin{array}{l}\text { Não - em } \\
\text { andamento }\end{array}$ & Não & Sim & Sim - boa & Sim & Fraca & Fraca & $\begin{array}{l}\text { Interven- } \\
\text { ção }\end{array}$ \\
\hline ONG 3 & 1997 & Jornalista & $\begin{array}{l}\text { Não - mas } \\
\text { tem emba - } \\
\text { samento } \\
\text { teórico }\end{array}$ & Não & Sim & $\begin{array}{l}\text { Não - em } \\
\text { construção }\end{array}$ & Não & $\begin{array}{l}\text { Sim - cursos e } \\
\text { troca de } \\
\text { idéias } \\
\text { com } \\
\text { professores }\end{array}$ & Regular & $\begin{array}{l}\text { Interven- } \\
\text { ção }\end{array}$ \\
\hline ONG 4 & 1991 & Educador & $\begin{array}{l}\text { Não - mas } \\
\text { tem emba - } \\
\text { samento } \\
\text { teórico }\end{array}$ & Não & Sim & $\begin{array}{l}\text { Sim - só } \\
\text { consultas } \\
\text { no local }\end{array}$ & Não & $\begin{array}{l}\text { Sim - gestão e } \\
\text { movimento } \\
\text { escola cidadã }\end{array}$ & Regular & Mediação \\
\hline ONG 5 & 1975 & Educador & $\begin{array}{l}\text { Não - mas } \\
\text { tem emba - } \\
\text { samento } \\
\text { teórico }\end{array}$ & Não & Sim & $\begin{array}{l}\text { Sim - regu - } \\
\text { lar }\end{array}$ & Não & Não há & Boa & $\begin{array}{l}\text { Interven- } \\
\text { Ção }\end{array}$ \\
\hline ONG 6 & 1987 & Jornalista & Sim & Sim & Sim & Não & Sim & $\begin{array}{l}\text { Sim - } \\
\text { interven- } \\
\text { ção direta nas } \\
\text { atividades e } \\
\text { grade horária }\end{array}$ & Boa & $\begin{array}{l}\text { Interven- } \\
\text { Ção }\end{array}$ \\
\hline
\end{tabular}

Fig. 02 Quadro comparativo de tópicos analisados nas 6 ONGs observadas 



\section{CAPÍTULO 6: ESTUDO DE CAMPO NA ONG 6}

Nos próximos dois capítulos, apresentamos a ONG na qual foi realizada esta pesquisa. As informações aqui expostas resultaram da leitura de documentos produzidos pela organização, observações feitas em campo e de entrevistas estruturadas realizadas com diversos participantes do projeto (coordenadora, educadores, professores e educandos), que foram registradas com um gravador. Desta maneira, buscamos traçar um perfil mais detalhado dos propósitos que permeiam o projeto educativo da organização.

Como esta pesquisa se caracteriza por ter cunho etnográfico, trazemos muitos relatos descritivos das atividades das quais participamos, bem como análises do que foi observado. Assim, procuramos, a partir de alguns princípios da pesquisa etnográfica, reconhecer o universo teórico que respalda as atividades da organização, tendo em vista verificar, principalmente, até que ponto a preocupação com a constituição de leitores e com o desenvolvimento do letramento está (ou não) presente.

Como resultado, iniciamos, no capítulo 6, com uma introdução da organização, seu histórico e modos de operação para, no capítulo seguinte, expormos e analisarmos o projeto "Círculo de leitura" (aplicado e instituído pelas educadoras da ONG e seus participantes), que constitui o corpo da nossa dissertação.

\subsection{ONG 6}

O primeiro contato com esta ONG deu-se por meio de um colega de Mestrado da FEUSP, que já havia participado de algumas atividades da organização, com o intuito de estudar as questões políticas e organizacionais implicadas na sua administração. 


\subsubsection{HISTÓRICO, PROJETO PEDAGÓGICO E ESTRUTURA}

\subsubsection{HISTÓRICO - Relato proveniente de entrevistas e documentos da organização}

A ONG 6 foi criada em 1987 por um grupo de jornalistas, sociólogos e empresários que sentiram a necessidade de constituir um fórum para estudar os problemas econômicos enfrentados pelo país. Tratava-se de uma tentativa de encontrar soluções a partir de pesquisas, publicações e debates, sobretudo no que se referia às políticas públicas como: segurança pública, educação e economia.

Com o passar do tempo e após inúmeras discussões, os membros da ONG 6 perceberam que os problemas econômicos estavam diretamente relacionados aos problemas sociais e que, portanto, não poderiam desvencilhar o econômico do social, na medida em que um se refletia no outro e ambos influenciavam-se reciprocamente.

A difícil situação econômica do Brasil tornava os problemas e as distâncias sociais cada vez maiores, ao mesmo tempo em que a situação social também não contribuía para a melhoria do panorama econômico, pois a maior parte da população continuava com vários comprometimentos em sua instrução e com poucas possibilidades de participar efetiva e ativamente das práticas sociais e cívicas da vida política e econômica do país.

Desta forma, aos poucos foi surgindo um núcleo de intervenção dentro da ONG 6 que, originariamente, era somente uma ONG de mediação. E dentro deste novo núcleo, surgiu o projeto "Círculo de Leitura". 


\subsubsection{PARCERIAS}

Essa ONG vive de patrocínios e a coordenadora do projeto é também captadora de recursos. Esses recursos são utilizados para financiar o jornal do Instituto publicação trimestral (Espaço de Opinião), os seminários promovidos, os livros que estão lançando sobre educação, o pagamento de pesquisa, material e os estagiários.

As parcerias são estabelecidas com diversas empresas e instituições financeiras. Como patrocinadoras, essas empresas acompanham os resultados das ações da ONG, porém, não interferem nas atividades nem na organização e estrutura dos projetos. $\mathrm{A}$ ONG tem a preocupação de organizar relatórios para os patrocinadores de maneira a deixá-los a par de tudo o que acontece na Instituição e de como seus recursos estão sendo utilizados. Além destes relatórios, existe um intercâmbio da ONG com um dos maiores parceiros, que encaminha regularmente alguns de seus funcionários e estagiários para visitarem a sede da ONG e participarem dos círculos de leitura (o principal projeto da $\mathrm{ONG}$ ), às sextas-feiras e aos sábados. Ou então, a própria ONG visita o parceiro, levando alguns participantes do projeto.

Há ainda os parceiros não-financeiros que vêm do círculo de amizades da coordenadora do projeto e trabalham voluntariamente. Assim, regularmente, há convidados especiais nos círculos de leitura que se propõem a orientar e coordenar as atividades. São em geral psicólogos, filósofos e artistas especializados em um tema. Há, por exemplo, um convidado especializado em Guimarães Rosa, outro em Cervantes. Durante o tempo de observação que realizamos, pudemos acompanhar um grupo coordenado por Eduardo Gianetti, jornalista, economista e professor do IBMEC, que leu "A riqueza das Nações", de Adam Smith, com os educandos.

\subsubsection{PROJETO PEDAGÓGICO / METODOLOGIA}

O projeto pedagógico "Círculo de Leitura" tem como objetivo desenvolver o gosto e o interesse de jovens de baixa renda pela leitura, estudantes de escolas públicas, de comunidades periféricas do ABC paulista, sobretudo de Diadema e de São Bernardo do Campo. 
Desde o início, fomos bem recebidos por todos os funcionários e participantes. Ao contrário do que ocorrera nas outras ONGs visitadas, nesta, a organização social facilitava o acesso ao seu trabalho, apresentando uma organização melhor do que as demais: recebemos uma apostila que detalhava a proposta metodológica do projeto, bem como o material utilizado e produzido pelos círculos de leitura: livros de literatura, brochuras e textos comentados pelos participantes (chamado pela ONG de "fluxo de idéias"). As impressões que registramos a respeito da primeira visita feita a esta ONG testemunham a organização do projeto:

Foi a primeira vez que uma organização apresentava sua proposta metodológica por escrito e fornecia uma cópia para nós. Além disso, da mesma forma que os participantes do projeto, ganhamos os livros lidos no decorrer dos círculos e cópias de contos e poemas utilizados. Mesmo sendo apenas visitantes, fomos recebidos como participantes, o que causou uma sensação de pertencimento $e$ facilitou o estabelecimento de interações dentro do grupo.

Segundo as coordenadoras, o projeto "Círculo de leitura" tem como uma de suas características receber visitantes (qualquer pessoa que esteja interessada em participar), pois acredita que uma pessoa que venha de fora pode sempre acrescentar um olhar novo para as questões que são discutidas. Assim, é freqüente a participação de visitantes: estudantes, professores, artistas plásticos e amantes da literatura em geral.

O próprio fato de a organização nos receber diretamente em uma atividade, colocando os pesquisadores em contato direto com os educandos e não somente em uma entrevista com a coordenação nos pareceu um bom indicativo da postura da ONG em relação ao seu próprio trabalho. Sentimos, desde o início, a confiança que a organização possuía em estar fazendo o melhor trabalho que podia e com toda a seriedade e fundamento necessário. Não sentimos que a coordenação queria nos esconder algo ou dificultar o nosso acesso, em momento nenhum houve este movimento por parte da coordenação, que sempre nos confiou o direito de analisá-la. 
Explicitaremos detalhadamente a metodologia de trabalho da ONG 6 mais adiante, quando apresentarmos o projeto "Círculo de leituras" na sua totalidade.

\subsubsection{AVALIAÇÃO}

A avaliação dos educandos é feita a partir da observação diária de sua postura nas atividades e de um questionário que eles preenchem no início e no final de cada ano. Assim, os coordenadores podem perceber mudanças nos educandos tanto no convívio quanto por meio das produções escritas.

Jurema, assistente de coordenação, contou-nos a história de uma aluna que havia demonstrado um processo claro de mudança na sua interação com o mundo (à parte o seu desenvolvimento na prática da leitura) quando esta afirmou que estava muito feliz, pois havia ajudado a Virgínia (educadora) a carregar a enorme e pesada mochila que sempre trazia. Segundo Jurema, ela afirmou: "porque eu sempre via a Virgínia carregando esta mochila, mas eu tinha medo de me oferecer para ajudar e hoje eu consegui fazer isso".

Podemos vislumbrar aqui a expressão de um processo de (re)construção da autoestima, fundamental para uma relação com o mundo na qual a superação do medo é favorecedora de interações menos díspares.

Em outra conversa com a pesquisadora, Daiane, aluna do Ensino Médio, participante do projeto já há alguns anos e também multiplicadora, afirmou que era muito tímida e calada e, por isso, nunca expressava seu ponto de vista nos círculos. Porém, com o tempo foi ficando mais à vontade e, instigada pelo educador, foi começando a falar. De início, ela apenas escrevia suas opiniões e depois entregava para o educador, porém, este, ao perceber sua potencialidade, passou a insistir mais para que ela participasse oralmente das discussões provenientes das leituras, o que a ajudou a vencer algumas barreiras.

À parte estes depoimentos e observações (que também foram registrados nas outras ONGs), verificamos, nos “círculos”, as atividades de produção escrita, feitas após 
a leitura de um conto, por meio das quais os participantes são convidados a escrever o que no texto lido foi mais importante, qual sua passagem favorita e / ou sua opinião sobre o que leu.

Há ainda, como forma de avaliação, a produção de diários nos quais os educandos colocam os temas surgidos no grupo a cada encontro, para poderem dividir com os outros colegas. Em média, há cinco produções escritas por ano que podem ser comparadas para avaliar o desenvolvimento dos educandos. Segundo a ONG, estas produções escritas não são apresentadas de "maneira obrigatória", porém os educadores lembram a existência de um acordo no grupo implicando que não escrever coloca o educando fora do grupo, ou melhor, da construção do patrimônio do grupo (o que na realidade, os obriga a escrever...). Depois que escrevem, os educandos lêem para o restante do grupo, a fim de que os colegas discutam como aquele indivíduo percebeu a leitura. Por vezes, os educandos mais tímidos são incumbidos de escrever o diário como contribuição para o grupo, o que, segundo a ONG, tem funcionado bastante.

De acordo com Jurema, no final do ano, estas produções escritas são avaliadas de acordo com os critérios do PISA, com o auxílio de especialistas em avaliação.

No entanto, durante nossa pesquisa, não acompanhamos o processo de avaliação. No grupo observado só houve duas produções escritas, ambas realizadas nos primeiros encontros. Talvez fosse necessário sistematizar essa avaliação, procurando fazer uma no início das atividades do ano e outra ao final do período do projeto com o intuito de saberem se, efetivamente, a ONG está colaborando para a melhoria do desempenho dos educandos, tanto no que se refere à produção escrita quanto à leitura.

A ONG não realiza um levantamento ou avaliação das leituras anteriores dos educandos que entram no projeto, portanto não traça um perfil dos participantes como leitores e, assim, não estabelece o universo cultural em que estes estão inseridos, nem o conhecimento de mundo que trazem. Este fato pode, eventualmente, dificultar a aceitação pelos educandos do material de leitura escolhido, uma vez que os participantes podem sentir que certos textos não correspondem aos seus horizontes de expectativas e não se adequam aos seus interesses e, como colocou Coelho (2002, p. 32), pode haver inadequação na "inter-relação entre sua idade cronológica, nível de 
amadurecimento biopsíquico-afetivo-intelectual e grau de conhecimento do mecanismo da leitura".

Como colocado por Paulo Freire (2002, 2006), é de fundamental importância que os educadores tenham em mente o mundo no qual seus educandos estão inseridos, suas realidades e referências. É certamente inadequado lidar com a leitura de mundo dos educandos se não se considera o contexto destas pessoas. Se partirmos do pressuposto da leitura de mundo, vamos buscar que os educandos leiam o nosso mundo ou o mundo em que se inserem? De forma que é preciso um conhecimento mínimo do outro ponto em que o educando está, do outro pólo com o qual também se dialoga, se não o que deveria ser um diálogo torna-se um monólogo que despreza a outra parte e a leitura de mundo que o outro traz consigo.

\subsubsection{FUNCIONAMENTO DA ONG}

No ano da pesquisa, a ONG atua em 18 escolas da região do ABC paulista, nos municípios de Diadema e São Bernardo do Campo, e possui a sua sede no bairro de Higienópolis, na cidade de São Paulo.

$\mathrm{Na}$ sede, ficam os escritórios e uma casa, chamada pelos participantes de "casinha", que recebe quinzenalmente os participantes do projeto, às sextas-feiras e aos sábados. Nesta sede, ocorrem as atividades administrativas (reuniões pedagógicas, fóruns, palestras, captação de recursos etc.) e também os "círculos de leitura" para os educadores e multiplicadores. Nessas discussões, originam-se os temas que devem ser tratados nas leituras feitas nas escolas. Assim, sempre é realizada uma leitura na sede antes de levar o texto para as escolas.

Sexta-feira é o único dia em que não há atividades nas escolas, o que permite a todos os educadores e multiplicadores estarem presentes na sede das $9 \mathrm{~h}$ às $16 \mathrm{~h} 30$. É também na sede, às sextas e sábados, que ocorrem os "círculos de leitura" com os convidados especialistas em alguns temas, como Eduardo Gianetti. Além dos funcionários e estagiários (todos advindos e participantes do próprio projeto), para esses encontros também são convidados alguns educandos dos grupos que se reúnem nas 
escolas - estes convites são feitos devido ao destaque que obtêm durante os "círculos". Nesses encontros, além de prepararem material para as leituras nas escolas, as coordenadoras buscam observar os novos participantes para, eventualmente, os convidarem a se tornarem multiplicadores e, posteriormente, educadores do projeto.

Segundo as coordenadoras do projeto, a vinda dos educandos para a sede da ONG é fundamental, para que possam multiplicar os círculos, realizar reuniões e saber o andamento das atividades nas escolas. É também importante para fornecer a estes educandos a oportunidade de saírem de seus bairros e "viajarem" para São Paulo, expandindo seus horizontes, visitando não só a sede como outros espaços da cidade. Em geral, a maioria desses educandos, antes de participarem do projeto, nunca havia estado no município de São Paulo.

Ressaltamos a preocupação das coordenadoras com a expansão dos horizontes dos educandos e, principalmente, o acompanhamento que realizam de suas atividades escolares. Verificamos uma constante preocupação com a observação e a avaliação dos participantes nestes encontros, às sextas e aos sábados, o que foi uma característica bastante positiva, uma vez que estavam constantemente procurando fazer pequenos ajustes e tentando resolver os problemas que apareciam, sempre em um processo de auto-avaliação.

\subsubsection{REGISTRO DE PRESENÇA E PERMANÊNCIA NA ONG}

É comum a evasão dos educandos do projeto. Por vezes, inicia-se com 60 educandos e termina-se o ano com 20. Porém, a ONG afirma que esses 20 educandos são freqüentes e dedicados ao projeto. Segundo Jurema, a ONG concentra-se naqueles que estão presentes e não se preocupa com os que foram embora.

Há uma lista de presença no início de cada encontro e é feita uma análise das frequiências para compreender os motivos da evasão. Quando se julga pertinente, buscase aumentar o grupo. 
Discutiremos o problema da evasão, do sucesso e do fracasso das atividades mais adiante, no item 7.3.4 do próximo capítulo.

\subsubsection{PROFISSIONAIS E VOLUNTÁRIOS}

Todos os educadores são contratados pela ONG, porém quase nenhum vem da área da educação. Entre eles há estudantes de filosofia, ciências sociais, administração, arte-oficineiros e de diferentes áreas voltadas à arte. Os requisitos para se tornarem educadores restringem-se ao seu desempenho nos "círculos", uma vez que eles são recrutados do próprio projeto. A grande maioria dos educadores veio do projeto-piloto em Diadema (que será apresentado mais adiante). No entanto, há voluntários que originalmente são educadores por formação acadêmica, como dois estudantes de Letras. O importante para a ONG é que seus educadores saibam criar o espaço de reflexão, independente de suas formações.

Além dos educadores, a ONG conta com os multiplicadores que auxiliam o educador na condução do grupo e escrevem o "Diário do Grupo" para que as coordenadoras saibam o que está acontecendo nas escolas. Os multiplicadores também são alunos da escola pública que participaram ou ainda participam dos "círculos de leitura”. Eles recebem uma bolsa-auxílio, vales para refeição e transporte e participam das reuniões na sede.

Há também estagiários, igualmente ex-educandos do projeto que trabalham no setor administrativo. Assim, a ONG dá oportunidade para os próprios educandos das escolas onde atuam, por meio de um trabalho remunerado àqueles que se destacam, o que parece ser muito estimulante para os alunos.

\subsubsection{ESTRUTURA}

O local onde acontecem os encontros semanais todas as sextas-feiras e aos sábados, com educadores, multiplicadores, convidados e educandos convidados (aqueles que se destacam nos "círculos de leitura" nas escolas e possíveis futuros multiplicadores), é um bonito sobrado de tijolos aparentes em uma pequena rua de 
Higienópolis, bairro de classe média alta da cidade de S.Paulo, onde também se localiza a sede (escritórios) da ONG.

O interior da casa é muito aconchegante e bem arrumado com muitos sofás, cadeiras, tapetes e almofadões. Posteriormente, em conversa informal com a idealizadora e coordenadora do projeto, Carina, soube que houve, durante a reforma do espaço, uma preocupação em tornar aquele lugar aconchegante, com "cara de casa", para que os participantes pudessem se sentir à vontade, como parte de uma família, o que notamos que efetivamente acontece. Na primeira visita realizada, antes de conversar com qualquer uma das coordenadoras, as anotações da época mostram que:

(...) logo que chegamos à casa fomos levadas até a cozinha onde encontramos Carina e um grupo de 11 educandos tomando café da manhã em volta de uma comprida mesa e ajudando a preparar os alimentos para o almoço. Tivemos uma impressão de união muito forte. Quando chegamos, a cena era familiar, não no sentido de ser habitual, mas no sentido de perceber aquele grupo como uma família. Sentados em volta da mesa, conversando, ajudando a recolher a louça, a cortar os alimentos, a limpar a mesa, pareciam todos irmãos. Quando entramos na cozinha, Carina foi a primeira a cumprimentar, e em seguida pediu para que nos apresentássemos para o grupo, explicando o porquê da nossa visita e de nosso interesse. Terminada a apresentação fomos convidadas a sentar à mesa e logo vários jovens começaram a conversar conosco em um ambiente bastante acolhedor. Foi um primeiro contato muito rico, pois foram os próprios jovens (de início instigados por Carina) que nos explicaram o funcionamento dos "círculos de leitura" e deram depoimentos sobre suas experiências no grupo. Esta conversa informal teve a participação, sobretudo, de quatro garotas. Os garotos se restringiram mais a explicar sobre o funcionamento do grupo e a ouvir os depoimentos das garotas, que se mostraram extremamente entusiasmadas em relatar suas experiências.

A casa constitui-se do piso térreo, onde há uma grande sala com poltronas, cadeiras e almofadas, além de bancos, banheiros, uma sala menor no fundo e uma 
clarabóia que fornece iluminação natural. É neste espaço que acontece a maior parte dos “círculos". São evidentes a procupação e o cuidado na construção deste espaço, montado de maneira a estimular e a convidar para a reflexão, a leitura e a sociabilização. A iluminação natural é ótima para as atividades de leitura e traz uma sensação de amplitude do espaço.

No segundo andar, há mais uma sala organizada da mesma forma, com sofás, poltronas, cadeiras, computadores e aparelhos de televisão / DVD e um banheiro. No último andar, há uma grande cozinha, um terraço, um banheiro e outra sala. Nas paredes laterais das escadas e na sala do nível intermediário, há livros expostos, alguns enfileirados como em uma biblioteca, outros deitados e outros, ainda, expondo a capa. Todos os livros estão à disposição e ao alcance dos educandos e o ambiente da "casinha", com os livros espalhados, parece transpirar "leitura". O espaço definitivamente foi muito bem pensado e elaborado para as atividades da ONG. Talvez, o que tenha favorecido o sucesso deste espaço foi o fato de ele ter sido reformado já com o intuito de abrigar o projeto.

\subsubsection{BIBLIOTECA}

Não há um espaço específico/formal que pode ser considerado como uma biblioteca de consulta para os participantes na sede da ONG. Na "casinha", há livros espalhados ao alcance dos educandos, que podem ser emprestados, como colocado no item anterior.

Ademais, o projeto fornece a todos os educandos os livros que estão sendo trabalhados. Assim, cada um tem o seu próprio objeto-livro e pode levá-lo para suas casas, ou para onde quiserem.

O fato de não haver um espaço específico para a biblioteca ou uma sala de estudo pode ser considerado uma falta, porém a maneira como a "casinha" foi 
estruturada cumpre o papel de estimular a leitura e permitir o acesso dos educandos a um dado acervo de livros.

Sem dúvida, um dos pontos mais positivos do projeto em relação ao acesso aos materiais de leitura é o fato de terem a possibilidade de fornecer para cada aluno o seu próprio livro. É muito importante a posse do seu próprio objeto de leitura, primeiramente porque muitos dos educandos atendidos nunca tiveram um livro, ou um livro novo só deles, e também porque assim sentem concretamente a posse da "leitura" - podem escrever, fazer anotações, dobrar/marcar as páginas e carregá-los para ler onde, como e quando quiserem.

\subsection{PROJETO “CÍRCULO DE LEITURA” - ORIGENS}

A origem do projeto partiu de um fórum de debates ocorrido em Diadema sobre o problema da violência. O diretor da ONG 6, um jornalista americano radicado no Brasil há 25 anos, acreditando que a ignorância e o não conhecimento eram as causas da violência e observando os problemas públicos e sociais da América Latina, montou os chamados "círculos de leitura", inspirado por seu amor à literatura, partindo do pressuposto de que a literatura e o diálogo poderiam contribuir para reverter o quadro de violência. Em parceria com sua esposa, a coordenadora do projeto, filósofa e psicanalista, eles começaram o projeto-piloto em manicômios, antes de levar para as escolas. O projeto baseava-se na realização de leituras e discussões feitas em grupo.

O projeto "Círculo de leitura" foi também uma continuidade e hoje engloba o projeto anterior, chamado "Biblioteca Escolar", que começou a partir do contato da ONG com as escolas, após os fóruns sobre violência em Diadema. Segundo Jurema, a maioria das escolas não possuía um acervo organizado ou, às vezes, nem possuía uma biblioteca. Preocupada com este fato, a ONG decidiu começar a criar e/ou organizar as bibliotecas escolares. Este programa ainda existe, e, em 2004, inauguraram duas bibliotecas em duas escolas estaduais de São Bernardo do Campo. Quem mantém estes espaços funcionando são educandos dos "círculos de leitura" que agora se tornaram agentes multiplicadores das Bibliotecas Escolares. Estes educandos ajudaram tanto na organização do acervo quanto nas atividades programadas, como contação de histórias, 
cumprindo o ideal da ONG de transformar a biblioteca em um espaço vivo, fazendo os livros circularem.

Os círculos de leitura nas escolas, propriamente ditos, começaram em 2002 com três instituições de ensino em Diadema. Em 2003, o projeto se estendeu para seis escolas de São Bernardo do Campo indicadas pela diretoria de ensino local. Essas escolas eram consideradas de risco, com níveis de violência muito altos. Segundo Jurema, a diretoria de ensino estava testando a ONG, pois se ela conseguisse manter as atividades nestas escolas é porque o projeto funcionaria.

Assim que o projeto começou, os participantes do "círculo", principalmente os diretores das escolas, foram contando para os outros colegas e o projeto foi aumentando, tanto que, em 2004, já eram 18 escolas (número que permanece até hoje). Atualmente, a ONG só vai a escolas que a convidam e que pedem para participar do projeto. A expansão do número de escolas é feita gradualmente.

Hoje, o contato com as escolas se dá, primeiramente, com a direção e com a coordenadoria, para quem o projeto é apresentado. Se a direção da escola concordar e aceitar o projeto, as coordenadoras da ONG entram em contato com os professores e, durante o HTPC (Horário de Trabalho Pedagógico Coletivo), elas promovem um "círculo de leitura" ou workshops/oficinas com os próprios professores. Posteriormente, a ONG solicita aos professores que divulguem o projeto junto aos seus alunos, bem como indiquem aqueles alunos cujo interesse julgam promissor. Jurema afirma que, sem o apoio da direção e dos professores, o trabalho torna-se muito difícil de ser realizado, pois seu apoio diário na escola auxilia na escolha de um espaço físico adequado e nas ações rotineiras e práticas. Assim, após as indicações, o projeto começa a ser realizado com os alunos, a partir de oficinas nas quais a proposta é apresentada e vivenciada.

A indicação feita pelas professoras dos educandos que participam do projeto é defendida pelas coordenadoras da $\mathrm{ONG}$, pois estas acreditam que se o grupo não for constituído por educandos interessados, as atividades não se desenrolam. Diante disso, comentamos com Jurema: 
Esse tipo de escolha leva-nos a pensar naqueles alunos que já são marginalizados, e que possuem, em geral, maiores problemas de aprendizado. Será que eles não terminam por serem excluídos novamente, uma vez que não são indicados para participarem dos círculos?

Diante dessa indagação, Jurema esclareceu que o pedido de indicação dos alunos não se baseia simplesmente em serem bons alunos, mas em serem os interessados, de tal maneira que acabem por chamar e atrair outros colegas para as atividades e, assim, atingir mais alunos. No entanto, o gráfico abaixo, de dados coletados pela própria organização, mostra-nos que o número de educandos que adere ao projeto por indicações de amigos é bem inferior ao número daqueles que vêm indicados por professores, diretores e pelo educador do projeto. A seguir, apresentamos dados sobre as respostas dadas à questão: "Como você soube dos Círculos de Leitura?", em dois momentos (Figuras 03 e 04).

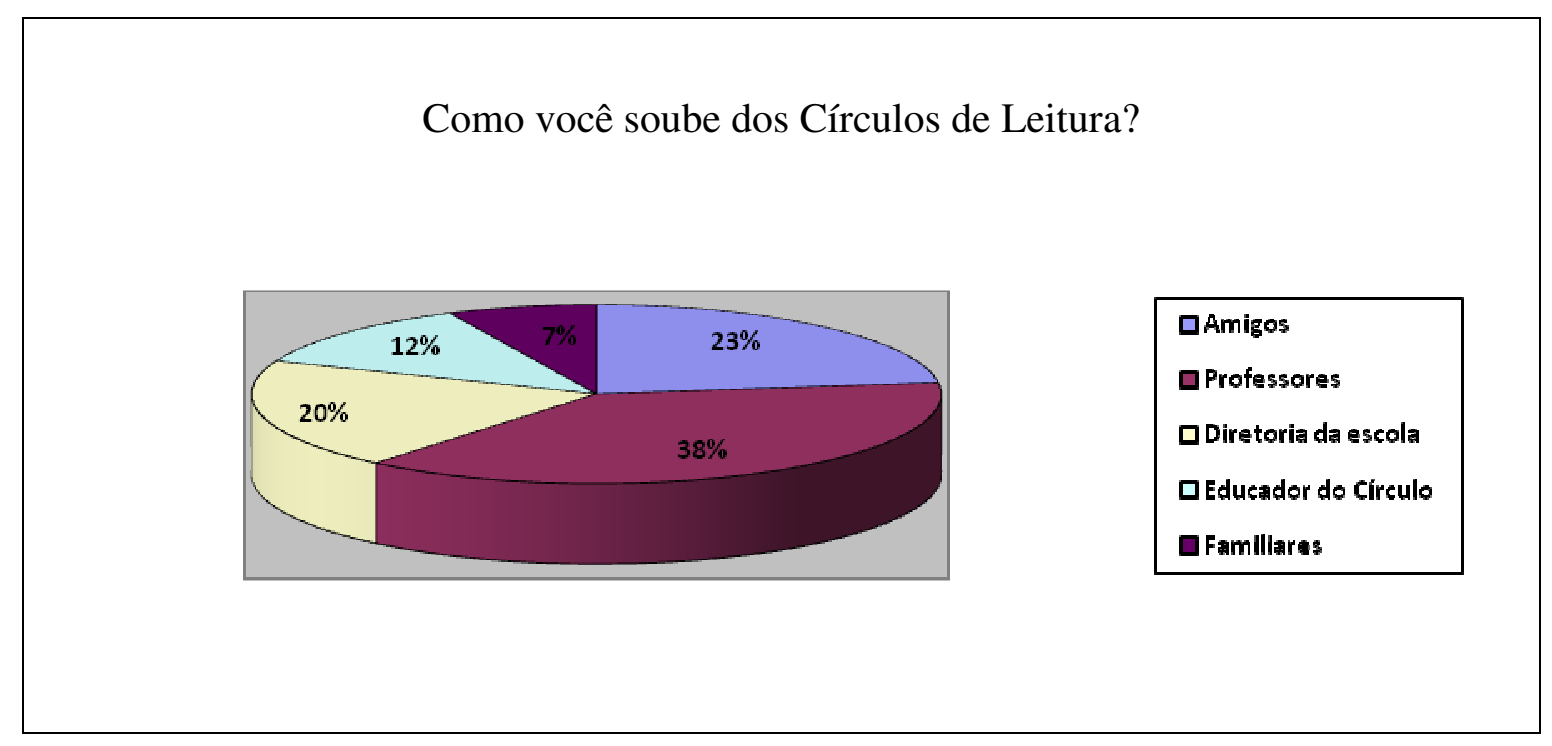

Fig. 03 - Dados resultantes do questionário inicial aplicado para 219 jovens no $1^{\circ}$ semestre de 2005 
Como você soube dos Círculos de Leitura?

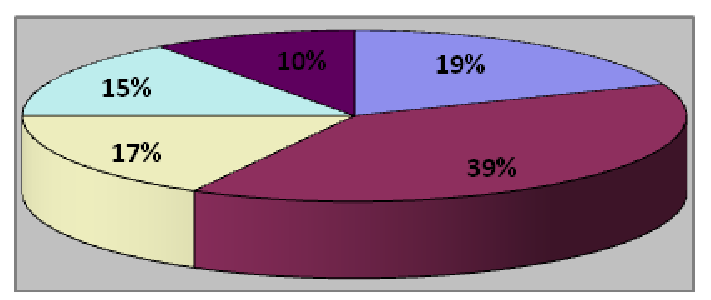

口Amigos

口Professores

口Diretoria da Eseola

口Educador do círeulo

口Familiares

Fig. 04 - Dados resultantes do questionário inicial aplicado para 123 jovens no $2^{\circ}$ semestre de 2005

No decorrer do estudo de campo, observamos uma situação que corroborou a explicação dada pelas coordenadoras sobre a diferença de atitude dos alunos indicados e dos não-indicados nas atividades do círculo:

Durante a participação em um círculo ocorrido em uma escola de São Bernardo (29/março/2007) que estava recebendo dois educandos que não haviam sido indicados pelas professoras, mas que haviam se interessado por conta própria, observamos que ambos se mostraram desatentos e desinteressados na medida em que a leitura foi se desenvolvendo. Enquanto os outros educandos participavam dos debates e sua postura corporal vergava para frente em direção ao educador, estes dois educandos ficavam recostados nas cadeiras, engajando-se em conversas paralelas e acabaram se retirando do círculo antes de concluídas as atividades.

Em contrapartida, obtivemos relatos de educandos não-indicados que participam/participaram dos círculos de uma maneira extremamente positiva e que, no entanto, possuem/ possuíam um histórico problemático dentro da escola.

Tendo em vista estas observações, é evidente que há alunos que apresentam mais resistência ao projeto e ao envolvimento com práticas de leitura, mas isso não deveria excluí-los do projeto, como se pode perceber de relatos como os mencionados no 
parágrafo acima. Na realidade, este deveria ser considerado o grande desafio do projeto: a constituição de leitores - a sedução de alunos inicialmente não interessados e nãoindicados, para a leitura.

Funcionando desta forma seletiva, o projeto permanece excludente e por isso não se constitui como uma atividade pública. Que o trabalho funciona mais facilmente com alunos indicados e interessados é evidente, mas seria bem mais expressivo se o projeto pudesse mostrar como despertar a capacidade de reflexão em alunos que desconhecem que a possuem. Esta talvez seja a observação menos positiva referente ao projeto.

\subsection{ONG, GOVERNO E ESCOLA PÚBLICA}

A ONG optou por trabalhar no ABC devido a um fórum de debates sobre violência, ocorrido em Diadema, e expandiu-se a partir do convite feito pela diretoria de ensino de São Bernardo do Campo.

O grande sonho da organização é um dia deixar as escolas e fazer com que elas próprias dêem continuidade ao projeto, incorporando-o nas suas atividades. Jurema, coordenadora, acredita que por enquanto isso não é possível, pois ainda se faz necessário chamar e motivar os educandos.

Ao ser perguntada sobre a visão que tinha do sistema público de ensino, Jurema contou que sempre estudou em escola pública, onde encontrou tanto bons quanto maus professores. Consideramos sua trajetória escolar (em escola pública durante toda a sua vida) importante e fundamental, pois indica tratar-se de uma educadora que viveu o cotidiano do sistema público como aluna. Não se trata de uma teórica que nunca pisou em uma sala da rede municipal ou estadual de ensino. Jurema evidencia sua vivência de 11 anos dentro do sistema.

Segundo a coordenadora, ela sempre se ressentiu do fato de as escolas públicas não aproveitarem os talentos que existem nelas e que vão se perdendo devido à falta de investimento ou incentivo. Jurema sentia que os alunos-problema recebiam mais atenção e investimento do que aqueles que apresentavam talentos, quando disse que 
(...) o foco fica no aluno problemático, que atrapalha a aula e o aluno que é bom, você sabe que ele é bom e você não precisa investir porque ele é bom. Você passa II anos na escola, e se você é bom, você fica no mesmo lugar, eu senti falta disso como estudante. Hoje eu sinto que a escola está passando por um processo de transformação, ela tem tentado, em grande ou pequena escala, modificar alguns padrões de antigamente.

Porém, contestamos esta queixa de Jurema, pois, em realidade, a escola sempre privilegiou os "bons alunos" em detrimento dos "maus alunos", por muitos anos os profissionais do ensino não souberam lidar com o chamado "fracasso" escolar. Os dados do PISA confirmam que quem não aprende continua sem aprender: muitos alunos continuam chegando ao Ensino Médio com um grau de letramento muito baixo. Se parece haver pouca atenção aos "bons" alunos, aos "maus" talvez haja ainda menos. Evidentemente que as questões que envolvem a rede pública de ensino são muito complexas e não pretendemos aqui tecer críticas ou analisar as condições e problemas que esta traz, e sim buscar colaborar para sua melhoria.

Outro problema apontado por Jurema é a falta de estabilidade no quadro de funcionários de algumas escolas que, em um curto período de tempo, têm uma rotatividade muito grande de diretores e professores, muitas vezes impedindo a continuidade no desenvolvimento das atividades na escola. Para Jurema, é preciso uma equipe de direção disposta a ficar e a mudar a escola. Assim, a ONG trabalha no sentido de apostar somente nas ações que estão dando certo, pois segundo Jurema, "se a gente ficar no pessimismo de que nada dá certo, a gente não faz nada".

De acordo com Jurema, o papel da ONG seria, portanto, criar um espaço para discussão dos problemas enfrentados na escola, reunindo pessoas de diversas áreas. Um exemplo disso foi o seminário ocorrido na ONG 6 sobre ensino de ciências que contou com a participação de professores da rede pública, da rede particular e de empresários. Cada um trouxe algo para adicionar, transformando a ONG em um espaço de discussão e, mais importante, de realização, pois segundo Jurema, "não adianta somente ficar no plano das idéias sem concretizar nada". O próprio "círculo de leitura" surgiu destes fóruns 
de debates e discussões sobre a violência em Diadema, como um complemento do Instituto.

De acordo com Jurema, se a sociedade ficar esperando que o governo desenvolva todas as ações educativas necessárias, não se empenhando em mudar pontualmente e em pequenos focos, as melhorias sociais dificilmente acontecerão. Segundo Jurema:

a gente está colocando uma grande responsabilidade nele [Estado], por exemplo, quando a gente vai para a escola, a gente sabe dos problemas que estão acontecendo, que nossos jovens estão se perdendo, aí a gente descobre o quê? Que a responsabilidade que é da família, esta não está conseguindo suprir, a responsabilidade que é da escola, a escola já tem muito o que fazer, e então para quem vai esta responsabilidade? Para ninguém? Então a nossa idéia é dividir um pouco, é começar a ajudar todo mundo a perceber que este é um papel de todos, não é tapar buracos, mas é fazer alguma coisa. Você começa a tapar buracos e vai encontrando outras pessoas para taparem este buraco juntas, e é justamente o que estamos fazendo, buscar aliados não só para tapar buracos, mas encontrar pessoas que saibam que há problemas estruturais e contestar esta estrutura. Como há ONGs que são assistencialistas, há programas do próprio governo que também o são, então é um problema. A idéia do "círculo de leitura" é criar pessoas autônomas que saibam procurar a possibilidade de que há bolsas de estudos em escolas particulares e outras coisas, que não há só o centro de São Bernardo, que há outros lugares, outras instâncias que podem oferecer muito a eles, sejam centros culturais, seja um emprego. Ele pode querer coisas fora daquele seu mundinho, e, principalmente, o sonho da Carina é que estes jovens que 
trabalham conosco possam fazer coisas para se sustentar. Fazemos oficinas profissionalizantes. Investimos no capital humano.

Há uma clara preocupação da ONG 6 em intervir e mudar as práticas de ensino nas escolas públicas, algo que não vimos em todas as ONGs estudadas no capítulo anterior. Esta intervenção é fundamental para que se socializem numa escala bem maior as mudanças e as próprias práticas de ensino trazidas pelas ONGs, e com isso provocar uma verdadeira transformação no ensino brasileiro. $\mathrm{O}$ trabalho para incluir as atividades na escola e para criar autonomia dentro delas, a fim de que elas mesmas continuem o projeto, é importante na medida em que não se busca mais uma ação assistencialista e sim uma verdadeira ação em parceria, que não cria laços nocivos de dependência. 


\section{CAPÍTULO 7 - ANÁLISE DOS DADOS CONCERNENTES À METODOLOGIA E ÀS INTERAÇÕES DOS PARTICIPANTES DO PROJETO “CÍRCULO DE} LEITURA"

Como previamente apontado no capítulo 6, neste descrevemos e analisamos o projeto "Círculo de leitura" da ONG 6, destacando a sua proposta metodológica, a bibliografia em que se baseia e a abordagem dos participantes em relação à leitura dentro e fora do projeto. Os resultados estão pautados no acompanhamento do trabalho realizado pela organização ao longo de um ano, a partir de observações, entrevistas com os participantes e análise de documentos, de atividades realizadas, e das relações dos educadores com os educandos. Sendo assim, a análise destas observações focalizou três eixos:

- Teoria: concepção de leitura e leitor que subjaz ao discurso dos participantes (coordenadores, educadores e educandos) do projeto "Círculo de Leitura", analisadas a partir de entrevistas e documentos fornecidos pela própria organização;

- Prática: proposta de trabalho e metodologia, relação com as escolas e interações entre os participantes, nos círculos, analisadas por meio de entrevistas, documentos e observações;

- Resultado: análise do projeto na perspectiva dos próprios participantes a partir de entrevistas e observações.

Lembramos tratar-se somente de uma divisão didática, uma vez que teoria, prática e avaliação de resultados são elementos inter-relacionados, que devem estabelecer coerência entre si. 


\subsection{TEORIA: CONCEPÇÃO DE LEITURA E LEITOR NA ONG - (entrevistas e documentos)}

\subsubsection{AS REFLEXÕES DA ONG SOBRE A LEITURA}

Durante a análise documental da proposta metodológica do projeto e das observações traçadas ao longo da pesquisa de campo, pareceu-nos que a ONG estudada possui uma visão muito clara do que, para ela, representa a leitura e o acesso aos bens culturais. Esta visão está diretamente relacionada à formação acadêmica e profissional da idealizadora do projeto, filósofa e psicanalista, permeando, freqüentemente, também as falas de seus participantes. Segundo o documento produzido pela organização,

\section{Este método busca desenvolver o gosto e o interesse pela leitura entre crianças e adolescentes de baixa renda em comunidades urbanas de periferia. A leitura tem a função de ampliar o universo cultural-afetivo desses jovens, normalmente bastante restrito. (grifo nosso)}

É interessante que a questão afetiva apareça logo nos objetivos do projeto, uma vez que, dentro da fundamentação teórica por nós apresentada, o prazer emocional, ligado à afetividade, deve ser um dos elementos principais na "conquista" dos jovens leitores, como foi discutido anteriormente. A própria idealizadora do projeto e alguns participantes, no decorrer do nosso convívio, usaram a palavra "sedução" para justificar o sucesso ou o fracasso do projeto em determinado caso. Assim, para a ONG, é fundamental que haja uma sedução para o universo da leitura, a partir, sobretudo, do afeto e da emoção.

A idealizadora do projeto, Carina, por ser também terapeuta, ditou um tom muito forte em relação à constituição da identidade dos educandos dentro do projeto e à sua humanização, um discurso muito semelhante àquele colocado por Antonio Candido (1995), como relatamos no capítulo 2 desta dissertação. Trata-se de um fato bastante interessante, visto que, quando indagada sobre os textos de Candido, Carina afirmou desconhecê-los. 
De acordo com o documento da ONG:

De forma geral [no mundo atual] acentua-se a tendência ao individualismo, à supervalorização dos bens materiais, à busca do prazer imediato facilmente descartável e substituível, ao sucesso rápido. Nesse contexto torna-se difícil a formação de uma identidade coerente e segura, que para se consolidar depende de parâmetros firmes, consistentes, constantes. Tais parâmetros nos chegam somente através de uma sabedoria estruturada em séculos e séculos de experiência, de história, de contato com a natureza e com o patrimônio cultural que chegou até nós. A linguagem humana, gravada, falada, escrita sempre se encarregou de difundir, ampliar, imortalizar para a posteridade uma herança inigualável. E é esta que buscamos transmitir a estes jovens e crianças, com os quais entramos em contato.

O projeto em questão afirma que busca criar oportunidades, por meio da leitura, da linguagem e do diálogo, para que jovens e crianças travem contato com a herança cultural da humanidade e, assim, enriqueçam seu conhecimento de mundo e possam consolidar suas identidades a partir de parâmetros "firmes e consistentes". Para as coordenadoras do projeto, terapeutas e pedagogas, é essencial o contato e o "reconhecimento deles [educandos] como seres humanos dignos de afeto e atenção" para que o projeto tenha êxito, tanto na constituição de leitores como na de indivíduos.

Verifica-se no discurso da organização, ainda que de forma secundária, a importância do aprender a criticar, discriminar e avaliar os textos que os educandos lêem. Dizemos "secundária", pois nos parece que a preocupação principal da ONG é com a humanização dos seus educandos a partir da leitura, ou seja, a ONG usa a leitura como meio de atingir um propósito maior do que o "desenvolver o gosto e o interesse pela leitura", não se concentrando na leitura por ela mesma, mas como um mecanismo de auto-conhecimento, como discutiremos mais adiante. Não há, assim, uma 
grande preocupação com o que chamamos anteriormente de prazer estético, de fruição estética de uma obra. $\mathrm{O}$ foco permanece, sobretudo, no prazer emocional e na relação catártica do leitor com o texto.

De acordo com a ONG,

Nossa primeira atitude em relação a um texto não é a crítica, mas a observação reverente. Se não acreditamos no autor quando o lemos, se não reverenciamos a obra que estudamos juntos, não sentimos a alegria e o conforto necessários para usufruirmos de sua verdadeira essência. As críticas geram um desvio da obra, o enrijecimento de uma determinada opinião sobre ela e, ao invés de se criar um trabalho com o texto se cria um outro tipo de estrutura, paralela a ela, que afasta aqueles que não são experientes o suficiente de sua verdadeira essência. Buscamos o universo primário da obra (não o secundário criado pela crítica) pois é ele que nos permite sentir a emoção e a partir dela dar significado ao mundo. [...] Ao compartilharmos as idéias, entramos no estado de devaneio criativo, em que as obras de arte são compreendidas - pretendidas dentro de nós - não pelo saber racional, mas pelos sentidos, pelo corpo.

Neste excerto, a ONG defende com mais clareza o trabalho com a leitura a partir do que chamamos de prazer emocional em detrimento do prazer estético, mostrando até um certo desprezo pelo pensamento intelectual e analítico. Há muita ênfase no sentimento e na parte afetiva, elementos que, como vimos anteriormente, possuem valor fundamental na constituição de leitores; porém, há um equívoco quando se exclui também o trabalho intelectual/racional do ato de ler.

Na busca para despertar o prazer da leitura catártica, a ONG acabou limitando as possibilidades que a leitura nos fornece. Acreditamos que, indiretamente, os educandos participantes do projeto possam desenvolver certas habilidades ligadas ao prazer estético, mas esta, certamente, não é a intenção principal da organização. 
Há radicalismo na negação da ONG ao trabalho da crítica literária, ao afirmar que as críticas causam um "enrijecimento de uma opinião" ou ainda "cria-se uma estrutura paralela à obra”. Entendemos que, se o diálogo está presente na leitura, uma crítica não deveria enrijecer uma opinião e sim enriquecer as discussões e trazer maior aprofundamento para a leitura. Concordamos que não se deve começar uma leitura pela sua crítica, ou com um vocabulário muitas vezes hermético para leitores iniciantes, porém, abandonar o trabalho de crítica literária parece-nos perigoso, no sentido de que algumas discussões podem acabar superficiais e nos "achismos" de seus leitores, sem o devido aprofundamento, o que foi observado em algumas ocasiões.

O discurso anti-crítica pareceu-nos um contra-senso em relação ao que observamos durante o tempo em que acompanhamos o grupo de Renato, mas, tendo observado outros grupos, sabemos que Renato é uma exceção entre os educadores. Este educador resolveu trabalhar a obra de João Guimarães Rosa com seus alunos do $3^{\circ}$ ano do Ensino Médio, e, nesse sentido, fez um vasto estudo por conta própria e trouxe muitos elementos da crítica rosaniana às discussões do grupo, o que consideramos importante e fundamental, tendo em vista o aprofundamento em alguns textos. Sua fala estava pontuada de temas que a crítica rosaniana apontou como específicos do autor, como a "querência":

\section{[12-04-2007] - Leitura do conto "Seqüência"}

Cauê: "Viera do Pãodolhão - sua querência"

Renato: GRIFEM aí esta parte, por favor marquem "sua querência". Essa querência é uma chave para a gente depois....

Cauê: $\bigcirc$ que que é isso?

Renato: Então, querência vem de querer. Mas a gente vai pensar depois, é uma chave importante para a gente depois entrar naquele jogo do infinito. Querência no Guimarães Rosa é uma palavra importantíssima. Guarda aí.

$[\ldots]$ 
Renato: E querençosa eu já vou adiantar o que é. É você falou do querer, que vem do querer. É, mas tem uma coisa nos contos de fada que é assim "o complexo de saudade", então sempre nos contos de fada tem um personagem que sonha voltar para algum lugar, tem saudade de algum lugar. Mas, em geral ele tem que voltar para algum lugar, sempre tem isso, geralmente tem isso. Isso é o complexo de saudade. E o Guimarães Rosa abrasileirou isso e chamou de querência. Então quando os personagens dele têm querência significa....

Cauê: Existe essa palavra no dicionário?

Renato: Existe. Acho que já existe, não sei, mas é engraçado porque se não existe, ela deriva de palavras que a gente conhece. Você já entendeu logo de cara que vinha do verbo querer, não é? Então a personagem querençosa do Guimarães Rosa, elas geralmente sabem mais do que as outras, só que elas não sabem exatamente o que é que elas sabem mais do que as outras. Têm alguma coisa muito delas, dentro do coração, elas sabem que existe um sentido muito maior além do que ela tá vivendo ali, ela quer ir para esse lugar, encontrar esse sentido. Então é isso que move ela, é um desejo tão profundo, é uma saudade, a querência nada mais é do que uma saudade. Você sente uma saudade de uma coisa que você não sabe exatamente o que que é, mas é essa coisa que te move no mundo e você vai pelo mundo para descobrir isso. E quando você chega lá nesse lugar, você descobre então, você tem um conhecimento que te ilumina. Na verdade, já falou que a vaquinha era querençosa, então tem um saber que move essa vaquinha, e o rapaz, olha lá, só um dos filhos, "rapaz, senhor- moço, quis-se, de repente, para aquilo". Ele QUIS, ele também tem querência. Ele também é querençoso. Então tem alguma coisa, que eu não sei o que que é ainda que move ele. Isso é muito platônico, uma idéia de que existe, de que a gente pertence a um lugar, a um tempo que não é o daqui da terra. E a nossa travessia nesse mundo é para tentar atingir esse tempo onde a gente é iluminado, onde a gente sabe de tudo, tem todo o conhecimento. Então, aqui na terra, quando a gente vai conhecendo as coisas, na verdade é só lembrar desse tempo para onde a gente está indo, este mundo das idéias. O Guimarães Rosa tem muito disso. Mas está claro a idéia da querência?

Neste mesmo encontro, o terceiro do grupo, no qual se iniciou a leitura do livro "Primeiras Estórias", Renato fez uma introdução sobre a obra do autor, iniciando o encontro com a explicação sobre os símbolos que apareciam nos desenhos do índice do livro e o significado da Banda de Moebius, o símbolo do infinito, deixando entrever por suas falas as inúmeras críticas que havia lido sobre a obra de Guimarães Rosa: 
[12-04-2007] - Leitura do conto "Seqüência"

$[\ldots]$

Renato: Lá no índice no final tem o nome dos contos e uma seqüência de desenhos, na verdade, no Guimarães Rosa nada é por acaso, cada palavra é muito bem pensada, ela remete a um monte de coisa. Então, ele sugere uma interpretação infinita, por mais que você pense que concluiu uma idéia em torno de um texto, sempre há uma coisa que abre para uma outra possibilidade de interpretação. [...] Mas de todo modo chama atenção o seguinte, que ele coloca aqui este oito deitado aqui, sabe o que significa isto aqui?

Cavê: É negócio de signo.

Renato: É tem isso, tem os símbolos do feminino, do masculino, tem um monte de coisa. Mas este símbolo, este primeiro, o oito deitado? Esse oito deitado é o símbolo do infinito, é também o símbolo do feminino. [...] Olha só, ele coloca no começo de uma seqüência o símbolo do infinito, e no final da outra seqüência o símbolo do infinito, você viu isso que eu falei, Cavê? E assim por diante, ele vai alternando, até que ele chega ao conto "Nenhum, nenhuma" que não tem o símbolo do infinito.

Cauê: Porque tem fim?

Renato: Não, na verdade tem. É porque é o conto número 8. Então, por isso ele não se deu o trabalho, então implicitamente ele está. Mas, porque será que este símbolo do infinito está aqui, no Guimarães Rosa? Por que vocês acham? Se eu disser que tem tudo a ver com a obra dele?

Carla: Ah, porque tem muitas definições, você pode ler, olhar de infinitas formas. Várias estórias.

Renato: Uh hum. E tem uma outra coisa que aparece, Carla, são 21 contos, no meio exato desta série de contos, tem um conto chamado "O Espelho", então, não bastasse esta idéia de infinitude, tem também um conto chamado "O Espelho". Ele é um gênio, então, ele reflete, não sei, nesse jogo doido de infinitude, você soma um jogo de espelho, é como se estes contos tivessem no meio deles, da seqüência, estes tivessem, imagina, se chocar com este espelho, então, aumenta ainda mais o infinito, com esse jogo de espelho, esse jogo virtual, e mais uma coisa interessante, tem um crítico que descobriu que estes contos se correspondem, da seguinte maneira: "As margens da alegria", o duplo dele é o último conto, "Os cimos", o segundo conto, corresponde ao penúltimo, e assim por diante até que se fecha no "O Espelho". Então, para um conto se corresponder com o outro, ele tem que atravessar este espelho.

Natália: O desenho do primeiro e do último são parecidos... 
$[\ldots]$

Renato: Ah legal, legal. Já tem esse jogo invertido...E por que que eu fiz isso aqui [segurando o símbolo do infinito que havia feito com uma tira de papel]. Com isso aqui fica mais claro. Tem matemáticos que passam uma vida estudando isso aqui. Isso se chama Banda de Moebius, que é o cara que estudou. Porque isso aqui tem uns cálculos matemáticos que eu seria incapaz de explicar para vocês, é exigir demais, mas eu vou mostrar para vocês o que pode virar com a gente cortando [ele vai cortando ao meio na vertical - pelo comprimento], tem um crítico do Guimarães Rosa, se eu não me engano um alemão, e ele escreveu um livro sobre o "Primeiras Estórias" cheio de cálculos matemáticos, e pelos cálculos matemáticos ele mostra que na verdade, dado este jogo de espelho, aqui não teria 21 contos, aqui TEM 21 contos, mas ele faz uns cálculos e ele chega a conclusão de que há muito mais do que 21 contos aqui. E ele mostra isso matematicamente. Por que isso (Banda de Moebius) se desdobrando uma na outra não tem fim. Então, só para vocês terem idéia, uma brincadeira com isso aqui é ver no que isso pode ir virando. $O$ que vocês acham que isso vira quando eu terminar de cortar?

Educandos: Não sei...

Renato: Ah uma coisa que eu não falei é que ela rompe com a noção de espaço também, né? Olha aqui, o que é que é dentro e o que é que é fora? Supondo que você me diga que isso aqui é fora, aí você vai caminhando e chega um momento que está dentro. E vice-versa. Então, aí você já não sabe mais o que é dentro e o que é fora. Rompeu com essa relação, agora é impossível você falar o que é dentro e o que é fora.

$[\ldots]$

Renato: Seja lá o que isso virar, vamos sempre relacionar com a estrutura do livro, ok? Vamos ver então... Olha só...Na verdade ela está duplicada, não é um círculo, ela dá duas voltas, aumentou, não se soltou...Agora vocês vão ficar pasmos, o que vai acontecer se eu cortar de novo?

$[\ldots]$

Cauê: Não tenho a mínima idéia. Quem inventou esse troço?

Renato: Pois é que tá, ninguém inventou, alguém descobriu. Porque assim já existe isso, e isso se explica matematicamente. Dois mais dois era quatro antes de um cara fazer esta soma...

Taís: Não sei quem é pior se os matemáticos ou se é os escritores. A gente estava fazendo um trabalho sobre escritores, aí o Fernando Pessoa tinha num sei quantos mil...

Renato: Heterônimos. 
Taís: Ele tinha um distúrbio não é possível.

Renato: Não é que ele tinha um distúrbio...

Cauê: Entrelaçou...

Renato: Entrelaçou, enfim foi o mesmo movimento que aconteceu? Não é inacreditável isso? Se a gente cortar de novo, fica um monte de argolas preso em uma argola maior. Todo mundo se espanta é muito legal. Tem gente que se dedica uma vida inteira para estudar isso. Bom, de qualquer maneira isso é por conta do Guimarães Rosa. Eu quis mostrar isso por que, Taís, sobre a estrutura?

Cauê: Que é infinito.

Taís: Que o símbolo mostra o infinito, que nunca vai ter uma preparação, sempre que você vai cortando... vou fazer este teste em casa.

Renato: E é uma tentativa de alguém que escreveu uma obra, é uma tentativa de tentar achar o quê? De atingir o quê?

Natália: $\bigcirc$ infinito.

Renato: Não, mas a gente viu que não tem infinito, como é que a gente vai atingir um fim com a idéia de infinito? Ele está tentando atingir, acho eu, não sei, alguém perguntou quem é o cara que inventou isso, ele não inventou...

Cauê: Descobriu.

Renato: Isso, assim como dois mais dois já eram quatro antes de alguém fazer esta descoberta. Então, é como se ele tentasse entrar nessas verdades eternas, essas coisas que sempre estiveram aí, e o que mais há para descobrir, né? Se um dia houve a banda de Moebius e alguém descobriu, quanta coisa que tá aí oculta que precisa ser descoberta? Então é este movimento por esta busca do saber, por esta verdade que só é dita assim, uma coisa levando a outra, aí o mundo vai se revelando. É um pouco isso, mas, assim, o mais interessante é a gente ver como é que ele faz isso na obra dele. A gente pode começar a ler então hoje...

Depois deste encontro, na volta para São Paulo, Renato afirmou, em tom de auto-crítica, que a aula havia sido um pouco didática demais, e completou que com o passar do tempo, ele havia sentido que os educandos precisavam de alguns dados conceituais, que eles pediam isso indiretamente, pois sem esses elementos muitos achavam que não estavam aprendendo muita coisa com a leitura. Após esta conversa, registramos no caderno de pesquisa: 
Acredito que estes elementos conceituais são fundamentais, fiquei intrigada com o tom de lamento de Renato em relação a dar uma "aula mais didática”, qual o problema? Achei o encontro extremamente interessante e os educandos pareceram deslumbrar-se com a complexidade daquilo que estava sendo apresentado.

No encontro que se seguiu a este, os educandos iniciaram o círculo contando ao educando Tiago, que havia faltado no encontro anterior, o que haviam lido e discutido, e, neste momento, uma das alunas reforçou a observação feita no caderno de campo:

\section{[19-04-2007] - Segunda leitura do conto "Seqüência"}

Taís: O Tiago perdeu a melhor parte desse conto. Quer dizer do livro. A explicação, aquele negócio que a gente falou [faz o símbolo do infinito com o dedo indicador].

No entanto, geralmente, durante as discussões e leituras, sobretudo as realizadas na "casinha", com Carina, há poucos comentários baseados em críticas literárias e inevitavelmente a leitura é direcionada com ênfase em um olhar psicanalítico. Ao realizar a leitura do conto de Gabriel Garcia Marques, "O afogado mais bonito do mundo", Carina, por exemplo, sugeriu que pensássemos a respeito da importância da relação que cada um ou que cada povo estabelece com seu passado, contida no texto. Há um viés psicanalítico bastante forte nas análises feitas por Carina e na maneira com que ela conduz o círculo. Esta observação levou-nos à seguinte anotação:

Os temas propostos por Carina, para serem pensados, sempre recaem sobre uma análise de cada um, pois busca fazer com que os participantes reflitam sobre o tema originado do texto, porém no contexto de suas próprias vivências. $O$ círculo de leitura pareceu-nos uma grande terapia em grupo. O que não consideramos negativo, já que sua proposta é, entendemos, a de desenvolver o prazer da leitura por meio da afetividade, do lado emocional dos jovens. Sem emoção, afeto e sensibilidade não existiria a literatura. 
Neste momento, no entanto, não havíamos ainda percebido que o trabalho com a leitura dentro do projeto, por vezes, acabava restrito somente ao prazer emocional, nem sempre caminhando em direção ao prazer estético.

Posteriormente compreendemos que a literatura e a leitura estavam ali, no projeto, como pretexto e ponto de partida para a discussão sobre eles mesmos e de temas humanos e universais que a eles pertencem. Não se trata, portanto, de uma aula de literatura ou de uma discussão literária, não se trata de discutir a forma, os gêneros, seu contexto histórico e seu impacto na sociedade e na cultura. O "Círculo de Leitura" focaliza a leitura a partir dos temas e questões levantadas nos textos. Cabe nos perguntar se o que envolve os educandos é mesmo a leitura literária ou a possibilidade de discutir e estar em grupo, de participar de uma "terapia em grupo". E se, efetivamente, um pode levar ao outro.

A proeminência dos aspectos psicanalíticos acaba, por vezes, reduzindo os aspectos que podem ser levantados na leitura, tornando a proposta do projeto bastante "unitária" e restrita. Sendo a realidade múltipla e os olhares dirigidos de diversos ângulos, não nos parece interessante evitar outras possibilidades que a leitura pode nos fornecer, outras maneiras de criticar um texto.

No entanto, é possível que, tendo a leitura dos textos literários como ponto de partida e construindo a auto-estima destes educandos como leitores (fazendo-os perceber que eles podem ler qualquer obra, que possuem capacitação para tal e que a leitura leva à reflexão prazerosa), haja mais chances de que estes alunos se tornem leitores autônomos e críticos. No entanto, ao conversar com Carina, esta demonstrou preocupação com o fato da maioria dos educandos não ler por conta própria, sozinhos, no seu tempo livre. Os educandos comparecem aos círculos de leitura, nos quais eles lêem, discutem e apreciam, porém, continuam não lendo fora dos círculos, nem o texto trabalhado em grupo, nem outros textos escolhidos livremente. $\mathrm{O}$ costume de ler não estava até o momento sendo adquirido pela maior parte dos participantes. Estes aspectos, de certa forma, reforçam a nossa hipótese de que a convivência e as discussões 
em grupo teriam mais importância do que a leitura por si mesma para os participantes do projeto.

Carina afirmou, no entanto, que estava se esforçando muito para atingir este objetivo, insistindo com os educandos sobre a necessidade de ler individualmente e sobre o enriquecimento propiciado pela leitura silenciosa e interior, diferente daquela feita em grupo. Acreditamos que cada educando precisa conquistar sua independência como leitor, tentar chegar a um nível crítico sozinho, refletir e raciocinar por conta própria e, sobretudo, apreciar e gostar de ler.

Acreditamos que o problema enfrentado por Carina (a não constituição de leitores) talvez esteja relacionado à sua própria base metodológica. A bibliografia do projeto (em anexo) aponta para uma direção psicanalítica, estando bastante carregada de livros de psicanálise e filosofia e com poucas referências a trabalhos de crítica literária e, muito menos, de ciências da educação. Não encontramos nela, por exemplo, trabalhos de Paulo Freire ou de Nelly Novaes Coelho.

Se a proposta é "desenvolver o gosto e o interesse pela leitura", há um problema entre este objetivo e sua base teórica. Há muita psicanálise e pouca teoria sobre a leitura e práticas educativas. A ONG 6, como mencionado anteriormente, usa a leitura como meio de ampliar o universo cultural-afetivo dos educandos, buscando desta forma ajudar a construir suas identidades. Ou seja, a leitura para eles é um meio e não um fim, um objetivo a ser atingido (o desfrute do prazer estético), como nos faz crer a sua proposta. Se realmente a proposta não for focalizada no trabalho com a leitura e sim com a constituição de identidade, seria importante que fosse alterada.

Partimos ambos (a ONG e nós) da concepção de que a leitura é uma recepção não passiva de mensagem, que nos serve para dialogar com o mundo e nos constituirmos como sujeitos históricos e sociais, sendo essa prática do diálogo mediado pela leitura uma prática libertadora. Entretanto, ainda que tais concepções estejam subjacentes aos trabalhos da ONG, esta, ao se restringir ao prazer emocional e não direcionar os educandos também ao prazer estético, limita o seu trabalho, na medida em 
que não os torna capaz de "dar o salto" (ao qual o educador Renato se referirá mais adiante), ou seja, de serem capazes de discernir uma leitura de qualidade artística/estética de um simples produto comercial que não favorece diálogo nem possibilidade de reflexão e, portanto, não colabora com a constituição de um sujeito social.

A concepção de leitura focalizada na constituição da identidade pode ainda ser mais problemática, não só por empobrecer a prática da leitura, mas porque pode facilmente cair no moralismo, na antiga concepção de literatura infantil segundo a qual a leitura deveria servir somente para o que se chamava "constituição de caráter" (Coelho, 2002). Este problema será melhor discutido quando analisarmos a lista de livros e a maneira como estas leituras são selecionadas dentro do projeto.

\subsubsection{EDUCADOR RENATO E SUA CONCEPÇÃO DE LEITURA E DE LITERATURA}

Em diversas conversas e na entrevista com Renato discutimos o conceito geral da leitura literária como encantamento. Renato explicitou a opinião pessoal sobre a importância da leitura como formadora da identidade e a importância da questão estética. Esses enfoques não apareceram no conceito de leitura da ONG, o que, talvez, explique a busca do educador por elementos provenientes da crítica literária para embasar seus círculos de leitura.

Renato mostrou-se bastante consciente do seu papel como educador e, também, claro e seguro sobre as concepções que possuía sobre o ensino da leitura, sobre a leitura propriamente dita e sobre a literatura. Em um dado momento, ao conversar sobre o ensino de literatura na escola, Renato fez a seguinte observação:

Em geral, nas aulas de português, principalmente de literatura, eu não tive bons professores. As aulas eram sobre HISTÓRIA da literatura, e MUITO superficial, então era assim: um período era conseqüência do outro e também para negar este outro período e ponto. A gente não lia as obras, a gente lia trechinhos assim ( $\mathrm{faz}$ o sinal de pequeno) e acho que faltou muito a história... faltou muito uma aula voltada para a estética 
literária que isso as escolas não têm. A gente não tem uma longa tradição disso no Brasil: estética literária. Então eu demorei muito para saber selecionar um livro, sabe? Eu li muita coisa assim, que eu não precisava ter lido até chegar, até conseguir saber: "Puxa, isso é literatura, isso é arte, isso não é muito interessante". Falta isso, então demorei a ter esse tipo de visão que a escola infelizmente não dá.

Esta fala foi significativa por mostrar sua preocupação com a estética literária, diferentemente do discurso da ONG. Ao mesmo tempo, ele corrobora a crítica feita por Jauss (1994) ao estudo da literatura nas escolas, no texto "A história da literatura como provocação à teoria literária". Para Renato, durante sua experiência escolar, as aulas de literatura equivaliam "a HISTÓRIA da literatura, de localizar o cara em algum lugar do tempo e determinar o que ele QUIS dizer, o que eu acho um absurdo. Eu tive aulas assim, a Clarice Lispector quis dizer tal coisa".

Indagado sobre sua posição frente à importância (ou não) da história da literatura, Renato afirmou:

Acho, claro que acho [importante]. Mas, te contam uma história de uma coisa que você nem sabe o que é, como se fosse distante de você, fosse privilégio de poetas. Então, a literatura é algo que só interessa a poetas e professores. Não tem sentido nenhum com você. Nunca vai te dizer nada, e você não é parte, parece até que é um gênero à parte do gênero humano, o poeta. Ele não é uma exceção do gênero que pode acrescentar para o próprio gênero, ele é uma outra espécie que não está relacionado com você. Ele é muito genial e a literatura é só de gente intelectual, você não tem contato... Acho isso absurdo, acho que precisa passar pelo encantamento mesmo. Assim, como quando a gente conta uma história para crianças, elas não querem saber se alguém escreveu aquilo, não, está dizendo com elas. Mais tarde ela lê que existe alguém que se dedica àquilo.

Aqui Renato traz à tona outra questão bastante freqüente: o distanciamento da literatura dos "seres comuns". A arte colocada numa torre de marfim é um problema 
constante quando conversamos com os alunos (que têm aulas de história da literatura e lêem trechos de obras sem reflexão e sem, sobretudo, compreensão - o que faz a literatura parecer ainda mais distante). Talvez por isso a ONG tenha tanto receio de incorporar a crítica literária ao seu trabalho, especialmente porque não possui também uma base didática e metodológica estruturada em leituras e pesquisas no campo educacional. Sabemos que há maneiras adequadas de introduzir elementos da crítica literária no contexto de uma aula ou de um círculo, como nos demonstra o próprio Renato.

Durante as observações de seu grupo, ficou claro seu foco no prazer emocional e estético ao trabalhar com os textos propostos. Renato deixou de lado, no entanto, qualquer referência histórica do autor e da obra e em nenhum momento introduziu o autor propriamente dito, partindo do pressuposto de que os educandos já o conheciam. Desta forma, ele não construiu nenhum horizonte de expectativa nos participantes, que não sabiam ao certo o que esperar da leitura que fariam, o que talvez possa ter prejudicado, de início, a empatia com o texto e com o autor.

\section{[29-03-07] - Leitura do conto "Os irmãos Dagobé"}

Após realizar a retomada do encontro anterior e estabelecer uma ponte temática com o conto que havia trazido para trabalhar com os alunos, Renato propôs a leitura de "Os irmãos Dagobé" como porta de entrada para a leitura de Guimarães Rosa. Sem tecer nenhum comentário sobre o autor, sua obra, importância histórica e características, Renato pediu para que os educandos antecipassem hipóteses sobre o que iriam ler, acreditamos que só baseados no título. Os educandos não souberam responder. Após um tempo, um aluno disse ter a ver com o tema do outro encontro - o que já havia sido exposto pelo educador. Evidentemente que não surgiram hipóteses por parte dos alunos, que não tinham nenhuma base que lhes permitisse criá-las.

Não queremos dizer com isso que o contexto histórico e a biografia do autor sejam mais importantes do que a própria leitura do texto em si. Concordamos com o 
educador e com Jauss (1994) que a leitura da obra é mais importante que os dados históricos, no entanto, estes não devem ser totalmente ignorados. Neste caso, talvez tivesse sido mais interessante traçar um panorama geral do texto, especialmente quando pensamos em horizontes de expectativas e em criar interesse nos leitores.

Nos encontros de leitura da "A riqueza das nações", de Adam Smith, o convidado, Eduardo Gianetti, propôs nos dois primeiros encontros traçar um panorama histórico e depois fazer uma breve biografia do autor antes de começarem a leitura da obra, o que foi bastante interessante e permitiu que os educandos já iniciassem a leitura por conta própria em suas casas, preparando-se para opinar quando a leitura fosse feita em grupo.

Em um dos últimos encontros do grupo de Renato, a aluna Penélope iniciou uma conversa indagando como seria a pessoa de Guimarães Rosa. Quando dissemos que traríamos uma revista sobre ele, a aluna ficou muito animada, demonstrando que tinha curiosidade e sentia falta de algumas informações prévias sobre o autor, que não se limitassem à sua obra, mostrando inclusive interesse em outros autores que fossem "parecidos com este".

Quando indagado sobre a função da literatura, na sua visão, além da questão formadora, mais uma vez a estética surgiu com muita força no seu discurso. Renato respondeu:

Eu acho que [a literatura serve] para você entrar em contato com saberes formadores de civilizações, da humanidade e também são saberes que nem sempre são considerados [...] Então, acho que quando você lê literatura, você tem acesso a outros saberes que, às vezes, colocam em discussão, é quando você descobre que você pode ser diferente do que de repente sistematicamente se estabeleceu que é o homem. Então é esta possibilidade de ser outras coisas. Então eu acredito nisso e também de você... mas, eu nunca tenho a literatura como refúgio: "Ah, porque a realidade está ruim, eu vou entrar no livro e acabou". Eu acho que eu sempre tive uma relação sublime com a 
literatura. Não é assim, ficar viajando na imaginação. Tentar trazer, saber que estes elementos foram dados por uma realidade, que pode se modificar e as relações com as outras pessoas, para mim a função é esta. E também a de puro encantamento, porque tem que saber, acho que na literatura você chega mais rápido em coisas que você não alcança objetivamente e que a humanidade talvez nunca venha a alcançar, mas você quando tem uma função estética, você é remetido a um entendimento que talvez nunca pode ser expresso nas relações cotidianas, nunca pode ser expresso sistematicamente, você sabe que 0 mundo é muito maior e você entende alguma coisa que só se expressa desta forma. Então, acho que é isso, não sei se responde, é sempre complicado falar disso. [...] O que é específico da literatura, eu acho que ela causa uma surpresa, assim muito maior porque trabalha com a língua e a língua tem umas armadilhas muito grandes, porque você pode sistematizar, codificar as falas e chegar, e assim, cria um vício de entendimento e de conceituação das coisas. Mas, quando você usa a literatura, ela dobra a sua língua a uma outra coisa, você tem um espanto de: "Mas o que estava falando? É assim mesmo?" Você entra em outro universo. Não sei, eu acho que isso é específico da literatura. Ela desmistifica, ela exige de você um outro dizer, porque para você entender, você tem que dizer também. Sair, abandonar esta estrutura lingüística da qual você está acostumado, você tem que dizer de uma outra forma. Quando você chega ao ponto de formular um pensamento para dizer de uma outra forma, você se transformou. A minha obsessão chegou um tempo que era isso: saber o que diferenciava. A questão não era só contar estórias. Porque tinha estórias bem contadas e mal contadas. Aliás quando eu era pequeno, depois que eu vim pensar nisso, mas assim eu detestava o Érico Veríssimo, eu adoro o Érico Veríssimo, mas não como escritor infantil. Então, eu lia lá "O urso que tinha música na barriga" e eu me perguntava: "O que que é isso?" . Eu achava um absurdo, NÃO me convencia de que houvesse um urso que tinha música na barriga. Mas, eu não me espantava nem um pouco do fato da Emília falar, do Visconde ser um sábio, um científico e etc. Era intuitivo, se expressava em uma aversão: isso presta, isso não presta, esse escritor é 
idiota e este é maravilhoso, era muito radical. Mas, depois eu fui pensar nisso, e isso voltou de uma outra maneira e me dei conta de que já pequeno eu tinha essa... intuição.

Após esta afirmação, indagado sobre como então ele buscava trabalhar esta questão estética nos círculos, se é que a trabalhava, Renato, então, respondeu:

Primeiro eu parto do denotativo, do que eles estão entendendo. Aí, depois a gente vai julgar aquilo, vai pensar as opiniões que eles têm a respeito da trama. Mas aí, a idéia é causar não um choque, mas pelo menos uma surpresa quando a gente vê que aquele juízo que estamos fazendo não é suficiente, não é bem assim. Olha só, vamos ver direito como está dito, aí, às vezes, eles dão um significado para uma palavra e julgam em cima daquilo, bom, mas será que esta palavra que está posta aqui quer dizer só isso? Então, é tentar, dessa maneira, partindo de um discurso... é conceitual, com os valores que eles já têm daquilo que há de denotativo no texto, a gente tentar ir desmoronando um pouco esse vício lingüístico, discursivo, para poder entrar neste outro universo. $\mathrm{Na}$ verdade é complicado, falar de um método assim, é uma coisa que eu só sei fazer... e também eu sei ensinar as pessoas a fazerem, porque a gente também forma multiplicadores, mas eu não sei se dá para dizer assim como é que é. Tem que passar um pouco pelo processo, mas a idéia é essa, o que há de imediato, tomar isso e aos poucos... Aí, às vezes, então eu aceito um juízo, eu sei que aquilo vai ser desmoronado depois, mas aí eu espero o momento certo para falar: "Então, espera aí, aquilo que..." E finjo que eu estou acreditando também, falo: "Nossa, então espera aí, isso já mudou tudo o meu pensamento, não é bem isso que eu estava pensando, porque tem esse detalhe aqui". E o Guimarães Rosa eu gosto de trabalhar muito, embora seja considerado difícil, e eu acho mesmo que é difícil, porque ele tem no estilo dele, essa capacidade inacreditável de parecer extremamente, obsessivamente realista, enfim aquela idéia dele sair com o caderno de anotações no sertão... Então, ele parece quase um cientista descrevendo POSITIVAMENTE uma coisa ali, mas tem um jogo que ele faz e com movimentos sutis ele te joga em outro universo. (...) Ou então, por 
exemplo, quando você lê um texto mais simples como "O Pintor, a cidade e o mar", aí é dito que ele entrou no quadro, e às vezes eu me faço de bobo e pergunto: "Peraí, vocês são tão inteligentes e vão me dizer que vocês nunca entraram num quadro?" Aí, eles não sabem se eu estou falando sério ou não, aí eu já falo: "Também não vou aceitar que vocês me digam que ele viajou na fantasia, na imaginação, falou que ele entrou, então ele entrou e pronto". Então, eles têm que criar recursos para responder isso. Aí a inteligência deles já foi valorizada e eles sabem que eles podem viajar, podem falar, até quebrar isso, então o grupo por si mesmo quebra. É só falar que eu não aceito certos clichês, por exemplo lá no "Dragão de fogo": "Ah, o importante é o amor, porque Dragão vê que o amor é a coisa mais forte que existe..." , mas "Peraí, tá bom todo mundo entendeu o que é o amor? Olha eu tô cansado de receber um monte de mensagens na internet falando que o importante é ser feliz, que o mais importante é o amor, isso não me transforma, por que isso é só um chavão, então vamos ver no que consiste este amor, onde está este amor, então a gente volta no texto, e vai ter que achar como este amor foi trabalhado e como o Dragão reconhece o amor" . Então, tinha algo denotativo, agora a gente vai para um outro aspecto, e eles vão e acham é só você desafiar, é só dizer que isso que está sendo dito não transforma, eu não vim aqui para falar as mesmas coisas, eu não vim aqui para vocês saírem dizendo "O importante é ser feliz", isso vocês já sabiam, já falavam, então não é isso, eu vim falar outra coisa, porque só falar isso, esta frase pronta, ela não tem efeito transformador nenhum, e eles entendem isso, é incrível, eles sabem que a gente está aqui para uma coisa diferente. Então tem todo um conjunto de coisas, não é à toa que nós sentamos em círculos... para poder dialogar.

De uma maneira não-sistematizada, Renato busca desenvolver nos seus educandos um sentido estético na medida em que procura fazer com que percebam que a linguagem literária é diferente da linguagem comum, ao fugir de "chavões" e frases feitas, mostrando aos educandos formas diferentes e mais complexas de se dizer as coisas e demonstrar suas opiniões. É desta maneira que ele procura trabalhar o estético dentro do texto, sem fazer uso de teorias ou denominações. Renato pareceu-nos proporse a ir mais além do que despertar o prazer emocional nos seus educandos. Há, nas suas 
intervenções e discurso, uma preocupação genuína com a forma e assim relaciona o prazer emocional ao estético, procurando fazer com que seus educandos caminhem de um para o outro. É instigante ver a descoberta da forma, do jogo de palavras pelos educandos:

[12-04-2007] - Leitura do conto "Seqüência"

Taís continua a leitura.

Taís: "(...) Àquelas qüilas águas trans".

Renato: Tem um jogo aqui, perceberam também? Aqui é o Guimarães. Aquelas águas tranqüilas. Mas quando ele desmembrou o que é que vira?

Cauê: Águas tranqüilas... [refletindo]

Renato: Mas porque o trabalho de escrever assim: qüilas águas trans? [pausa de 6 segundos]. Não sei, acho que é um pouco assim...

Cauê: Que ele escreve uns negócios muito difíceis.

Renato: É, mas isso não tá, a gente tem um exemplo claro disso, porque será que ele fez isso, vamos ver. Todo o significado desse livro. Ele entrou naquelas águas, naquelas qüilas águas trans, ele podia ter falado tranqüilas, aí seriam SÓ águas tranqüilas, o que traz essa idéia?

Cauê: É como se trocasse de mundo.

Penélope: Trans de transformar.

Renato: De transformar, de TRANSCENDER. Eram águas tranqüilas, mas não era só isso.

Carla: Tinha algo de especial. Que podia ser a transformação dele.

Renato: Então mudando a ordem, não é mais uma coisa familiar, um dizer tão especial que não pode ser linear, tenho que inverter, não tem mais essa ordem direta com a qual a gente está acostumado, dizer que exige um reverter das palavras, um desmembrar. Vocês pegaram, né? Eram tranqüilas, mas iam além. Transcender. 
[19-04-07] - Leitura do conto "Seqüência"

Tiago: "O rio liso e brilhante, de movimentos insensíveis..."

Renato: Invisíveis...

Cauê: Eu falei a mesma coisa! Na semana passada!!!

[Todos concordam e riem]

Cauê: É, tem alguma coisa errada com o livro!

Renato: Não, não. Nunca é à toa quando a gente tem esses atos falhos assim...movimentos insensíveis...

Cauê: Eu falei a mesma coisa... juro!

Renato: Pois é, é engraçado isso... Fala...

Taís: Renato, sempre quando chega aquela hora que fica repetindo "longa, longa, longa", você começa a rir...

Renato: Eu não sei... é que é tão bonito, não é bonito como vai falando? Tem um momento, acho que é n' "As margens da alegria" que ele diz "a longa, longa, longa nuvem"... não sei.

Cauê: E o "irrompida ida"? "Até que outra cerca travou-a, ia deixando-a desairada. Volveu - irrompida ida: de um ímpeto então a saltou: num salto que queria ser vôo".

Renato: Aonde é que está?

Cauê: Nesta mesma página, mais em cima.

Renato: $O$ que você quer dizer com isso?

Cauê: "Volveu - irrompida ida: de um ímpeto então a saltou". Irrompida ida. É engraçado.

[Todos riem]

Renato: O que é uma irrompida ida? Rompe depois segue...?

Cauê: É engraçado...

Penélope: $\bigcirc$ que é volver?

Renato: Voltar. 
Taís: Não teve uma parte que ele colocou a palavra separado e a gente ficou falando?

Renato: Volver não é português, é espanhol, não é? Mas, o Guimarães, ele sabia 13 línguas.

Taís: "É as qüilas águas trans".

Renato: É, "as qüilas águas trans". É maravilhoso, née Isso vai dando um gosto especial, não é? Ele tem umas frases... "Deu patas às fantasias", né? Tem umas expressões espantosas para a gente...

Cauê: Ele fala muito estranho.

Renato: E é uma maneira também...

Cauê: Ele fala muito estranho. Ele ESCREVE muito estranho.

Renato: É, escreve. Mas é lindo não é? Vocês não acham bonito?

Natália: Do jeito que ele escreve dá para imaginar várias coisas.

Cauê: Eu acho estranho.

Renato: E é estranho.

Natália: "Ela se desescondia dele. Inesperavam-se".

Renato: "Inesperavam-se?" - Isso é interessante, porque não existe o verbo "inesperar", não é verdade? Existe o inesperado e pronto. Não existe "Eu inespero, tu inesperas, ele inespera...", né? Não existe esse verbo, porque será que ele cria esse verbo?

Carla: Acho que ele quis dizer: esperavam-se?

Renato: Esperavam-se, mas sem saber? Inesperadamente eles se esperavam? Não é maravilhoso isso? Ele cria um verbo para dizer isso...

Taís: Eu acho que é uma mistura...

Renato: Quantas coisas nos inesperam? Esperamos sem saber que esperamos?

Tiago: MUITO estranho.

Renato: A idéia é essa. Não é para a gente abrir o livro e ficar na mesma. É, mas esse estranhamento, Tiago, eu acho que ele vira intimidade, a partir do momento em que a gente, em que ele começa a jogar a gente para esse outro lado. Não parece, porque cotidianamente ninguém fala assim, não é verdade? Ninguém que for te contar uma história, vai te contar nessas palavras, nestes termos. Ninguém vai te falar: "Olha, ela se jogou naquelas qüilas águas trans". Vão pensar que a pessoa tá meio louca, mas o que que 
acontece quando tá escrito aqui? Ai, Meu Deus! Você tem que entrar no jogo do cara, e quando você entra no jogo do cara, você está em outro lugar, em outra realidade, não é verdade? Então, pela linguagem é uma maneira de se lançar nesse mundo.

Cauê: Eu nunca ia falar para uma pessoa: "o avanço que levava, não se o the dava de o bastante". Eu não vou conseguir falar isso.

Renato: Pois é, mas é essa estranheza que vai te pôr em um outro movimento. Né, Carla? Porque a Carla olha assim... Você sente isso? [Os alunos riem, e fazem mais ou menos]. Você não sente que está em outro universo, Tiago? Parece uma música que vai te levando... Bom, vamos embora. Eu fico muito feliz quando vocês percebem essas coisas.

$[\ldots]$

Tiago: "Como cortando o mundo em dois, no caminho se atravessava - sem som. Seriam buracos negros, as sombras perto das margens".

Renato: Além de estar escurecendo, tinha umas sombras perto das margens.

Cauê: Pareciam buracos negros...

Renato: É um lugar muito escuro, muito, muito escuro. Haja querência!

Cauê: É aqui fala da mãe do breu!

Renato: É ele vai para a casa da mãe do breu.

[Todos riem]

Renato: Viu Thomas, escuro é pouco, sabe quando a gente fala escuro, é mais ainda é a...

Cauê: CASA DA MÃE DO BREU! [Ri]

Renato: Aí você vê que o negócio é perigoso. Uma coisa é ficar no escuro, mas ir para a casa da mãe do breu. O negócio muda de figura. É ou não é?

[Meninos riem]

Taís: Ai que bobos!!!

Cauê: Bobo é ele que escreve essas besteiras!

Renato: Besteiras?

Cauê: Besteiras não...

Renato: Olha a cara de vocês...vocês já estão nesse universo, é uma maneira de te levar lá. 
Cauê: Mas, "mãe do breu" é da hora!!!

[todos riem]

Renato: É, mas é maravilhoso, olha só...

Cauê: Da hora, da hora....

Renato: Porque o escuro só não é suficiente, falar que estava escuro, e daí? Meu filho, escuro, parecia um buraco negro, além de estar escurecendo naquela hora, tinha umas sombras nas margens e mais, se você atravessar esse rio você vai parar em outro mundo, e nesse outro mundo, você pensa que é só chegar e já é luz? Não, você ainda vai passar pela casa da mãe do breu. Porque são essas provações desses heróis. Vocês conhecem a Odisséia? É um modelo, a Odisséia, o cara sai e vai passar 20 anos por provações, para conseguir voltar e ter aquilo que você deseja, você tem que passar por muitas coisas ainda. Você vai ter que passar por terras onde gigantes devoram homens, você vai ter que ouvir o canto de sereias com o risco de se lançar no mar... Até você chegar na sua Ítaca, você se sentir digno... Porque de certa maneira, a gente pode pensar que este rapaz está indo para a Ítaca dele. É a Odisséia desse cara. Então, na Odisséia, Tiago, a gente ri quando fala da casa da mãe do breu, e é engraçado mesmo, dá uma graça. A gente se desarma quando a gente ri, a gente cria uma empatia e se envolve mais com a história. É como pensar quando Ulisses da Odisséia vai no Hades, que é o lugar dos mortos. Então, é um pouco essa provação do herói. Você tem que atravessar os silêncios, assim para buscar esse conhecimento... essa querência. O Dante lá na Divina Comédia, ele não vai lá no inferno, é a história de uma ida aos infernos, né? Então, você tem que ir no inferno para resgatar... não importa até onde você tem que ir, você precisa ir no inferno para poder resgatar isso... Os heróis passam por isso. Por isso, não é qualquer um que vai até a casa da mãe do breu. "Eu ir na casa da mãe do breu? Tá louco, eu passar por isso?" É a provação. Tudo bem você não quer passar, então volta para a sua casa, volta para a Pedra, né?

Cauê: É verdade.

Para o educador, o processo de leitura envolve muitas variáveis. Ele fez a seguinte reflexão sobre o que seria preciso para saber ler.

\section{[12-04-2007] - Entrevista}

Renato: É interessante isso, porque geralmente a gente pensa que pelo fato da pessoa ser alfabetizada e ler fluentemente já é suficiente para ela ler qualquer coisa. Eu acho que você tem que ter repertórios, é... anteriores, eu tava falando da minha avó, e dos exemplos das histórias, é... acho que para você ter acesso. Eu posso ler um texto do Guimarães Rosa, entender 
denotativamente, fazer até um texto crítico sobre ele, mas nem por isso significa que eu tenha sido afetado pelo texto. É difícil falar disso, eu quero dizer que é como se aquelas portas de passagem para este outro universo, tem que ter acessado isso antes de alguma maneira, se não fica mais difícil para você acessar. Acho que o que a gente faz é abrir estas portas, mostrar um pouco este caminho, para este outro universo, que aí sim eu acho que o leitor se torna completo, ao menos, se tratando de literatura. [...] Conhecimento de mundo... É, mas aí que tá, é num outro nível de conhecimento, de uma experiência mesmo vivida, de uma realidade possível. Eu digo isso, por que assim, mesmo na faculdade, eu tenho muitos amigos meus que lêem muito, mas têm justamente esta dificuldade desta entrega para um texto literário, ou para uma obra de arte de modo geral.[...] Acho que isso vem do repertório, somada à defasagem na própria alfabetização, porque você acha que você lê fluentemente um texto, significa que você é um leitor completo, quando eu acho que não.

Pesquisadora: O que está entre este leitor que lê fluente mas você acha... Onde é que se dá este salto da leitura?

Renato: Aí é que está, é um pouco polêmico isso. É que eu não SEl se todo mundo dá este salto... eu não sei se eu posso exigir de todo mundo, neste sentido que eu julgo um bom leitor em se tratando de texto literário, eu não sei se eu posso exigir que todo mundo tenha esta entrega, eu acho que não. Eu não sei se ESTA experiência SUBLIME é para todas as pessoas. Eu tenho sérias dúvidas quanto a isso. Para começar, o projeto "Círculo de Leitura" é bem seletivo, então, se você quer somente uma aula TÉCNICA, você não vai ter, tanto que hoje, por exemplo, a gente fez uma coisa mais didática, mas eu falei semana que vem a gente vai retomar o texto e viajar, tem uma outra experiência aí. Eu não sei se todo mundo precisa passar por isso. Olha, sinceramente, eu até queria poder responder precisamente, mas eu não consigo, não sei se eu posso exigir.

Pesquisadora: Você disse que hoje foi mais didático, em que sentido?

Renato: Não, não foi mais didático... eu trouxe informações mais é... estruturais, estéticas... Mas, não me basta só o cara pegar o Guimarães Rosa e saber disso, eu quero que ele VIVA aquilo mesmo. Então, vamos ver até que ponto a gente consegue viajar agora com significados nossos neste texto. Vou me entregar agora e vou viajar, é quando a gente começa a falar as coisas mais mirabolantes, a gente se empolga muito, e não tem nada de lógico naquilo, é essa a intenção, né? Com este contraditório, este paradoxal. Um dia uma menina falou: "Isto está relacionado com o 'Nada e a nossa condição', eu acho que na verdade este rapaz na idéia de atravessar o espelho, ele cruza o espelho e se torna o velho do 'Nada e da nossa condição'"'! E era perfeitamente possível para a gente aquilo, então coisa desse tipo. Embarcar nessa onda.

Pesquisadora: $\bigcirc$ que me intriga é onde se dá este salto...

Renato: É para mim também, como que muda, que botão você aperta lá e você toca. Eu acho interessante isso, por isso eu coloco em dúvida... 
Claro que a pergunta continua, se é para todo mundo, mas tudo bem, mesmo que não seja para todo mundo, para aqueles para quem é, onde é que é o lance. Porque aí, eu vou brincar com aquele texto do Fernando Pessoa: aí você pode falar que é o poder da graça, do divino espírito santo, do bom anjo da guarda, ou enfim, o nome que você quiser dar, junta com a parte do mistério. Este texto é apresentação que ele faz do livro "Mensagem". Eu gosto inclusive de ler no texto, porque vai mostrando os níveis diferentes, pelos quais você passa para ter acesso a uma interpretação satisfatória. E é muito bacana, a simpatia, a inteligência, o pensamento quando se torna analógico, passa do discursivo para o analógico, isso também é importante. Uma coisa remetendo a uma outra coisa, né? Eu gosto do Guimarães Rosa de novo por isso, porque neste movimento circular a relação se dá, de alguma coisa que talvez você não saiba dizer conceitualmente, mas aí o próprio Fernando Pessoa no último parágrafo já joga um outro elemento, bom agora é o mistério de novo. Ou seja, tudo isso para cair no mistério de novo que é a graça, talvez tenha também esse aspecto de também poder insistir no mistério, revelar, mas insistir. Eu sei que tem uma responsabilidade objetiva de despertar isso nas pessoas... ainda estou pensando.

Permeando todas as falas do educador Renato existe uma concepção de leitura e também de literatura que se aproximou muito mais da concepção com a qual trabalhamos na presente pesquisa do que aquela apresentada pela própria organização, uma vez que além da preocupação com o prazer emocional, ele tem uma preocupação com a busca do prazer estético e, conseqüentemente, com a busca de um diálogo humanizador e reflexivo.

O "puro encantamento" (prazer emocional) está relacionado, para ele, com "uma forma diferente de se dizer as coisas" (prazer estético) e é esta forma diferente de colocar as idéias que confere à literatura um potencial transformador, que transforma as relações do sujeito com o mundo, que fornece diálogo e contato com diferentes "saberes formadores das civilizações".

\subsubsection{EDUCANDOS E LEITURA}

A partir de entrevistas feitas com diversos educandos do projeto "Círculo de Leitura”, obtivemos uma gama bastante variada de conceitos sobre leitura e sobre o que consideravam ser bons leitores. Estes conceitos foram surgindo de três perguntas feitas: 
1) Em sua opinião, para que servem a leitura/ os livros? Servem para alguma coisa?

2) Por que você lê?

3) O que é ser um bom leitor? Você se considera um bom leitor?

Lembramos que as entrevistas foram gravadas, em geral na biblioteca da escola, espaço onde ocorriam os "círculos", somente com a presença da pesquisadora e do aluno entrevistado, portanto sem interferência de educadores, coordenadores, professores ou colegas.

Foi bastante comum obter dos educandos comentários sobre a "beleza" da leitura e o estabelecimento de relações diretas entre boa leitura e fluência na oralização do texto (leitura em voz alta):

Laura: Ah, boa, boa leitora assim não. [...] Um bom leitor é tipo que saiba, tipo interpretar, sei lá, falando, demonstrando aquilo que está lendo. Acho que eu ainda tenho que, sei lá, às vezes, eu ainda fico meio nervosa ainda para ler alguma coisa assim. Fico nervosa quando eu não consigo falar, pronunciar as palavras, eu fico super nervosa mesmo, enrolo a língua, porque, sei lá. Não é sempre, só quando está difícil, as palavras, uma ou outra, não o contexto todo [...] (Com o projeto) desenvolvi mais....Tipo em voz alta, tinha vergonha, perdi a vergonha totalmente, mas foi bom ajudou a desenvolver a minha mente [...] Teve bastante mudanças. Até os professores sentiram esta diferença, né? Porque antes, eu lia, mas eu lia para mim, sabe? Aquela coisa assim (ela quer dizer travada), vergonha dos outros falar alguma coisa, principalmente se eu errasse alguma palavra, e os professores mesmo falaram que na leitura eu mudei muito, muito mesmo. Antes eu lia para dentro e ninguém escutava, falava baixinho, para mim mesmo, e quando o professor pedia para eu explicar: Nossa Senhora! Que dificuldade! Eu lia, lia, lia e não conseguia explicar, viajar mesmo. Agora eu consigo explicar, vou até além, porque é, porque não é, entendeu?

Taís: [O bom leitor é aquele que sabe] Ler bem. Não ficar fazendo aquelas PAUSAS assim, saber a pontuação, porque tem a pontuação ali, por mais que não implique nisto, mas, se a pessoa lê que nem um... sem a vírgula, sem o ponto, parece um jogo de futebol narrado. E saber entender, saber passar o que você entendeu do livro. Eu acho que sou uma boa leitora, eu não leio muito, mas, quando eu leio, eu, geralmente em tudo que eu faço eu me aplico para fazer o melhor, e quando eu leio eu tento entender, eu tento ler bem, eu tento aumentar o meu vocabulário, eu pergunto as palavras que eu não sei para saber o que é. 
Além de afirmarem que a leitura ajuda a aumentar o vocabulário e, portanto, a se expressarem melhor, os educandos apontaram como principal contribuição da leitura ajudá-los a interpretar e a aprender:

Laura: É importante, porque nós aprendemos muitas coisas, muitas pessoas dizem: "ai, sei lá, isso é coisa da sua cabeça", mas não, a gente lendo, a gente aprende MUITA coisa mesmo, desenvolve a mente mais, a gente fica por dentro das coisas, que pode acontecer e que não pode... Agora eu posso dizer que é porque eu gosto de ler. Gosto de ler e ficar por dentro, sei lá, das histórias, das coisas, poder viajar um pouco, comigo mesmo.

Taís: Serve. Primeiro, porque você aprende a, na minha opinião, quando você começa a ler o seu vocabulário aumenta, você fala muito melhor, e o livro sempre tem alguma coisa para te passar. Depois do círculo de leitura eu aprendi a ver que o que os escritores escreveram não foi só porque eles estavam com vontade, mas porque eles tinham alguma coisa para passar para o mundo, que eles queriam que mais alguém entendesse e soubesse.

Cauê: Serve. Depende do livro, dá um sentido... pode até melhorar a vida de uma pessoa, depende do estado da pessoa também. Às vezes, ela lê uma estória falando da vida de alguém, essa pessoa sofreu muito, essa pessoa acha que ela é sofrida, aí ela percebe que a vida dela é linda, maravilhosa, perto do que ela leu, entendeu? Isso pode até inspirar uma pessoa na vida. E também conhecer palavras, também qualquer livro, para falar a verdade, serve para isso. Interpretação, acho ótimo isso. E é isso.

Tiago: Ah, com certeza, serve sim. Acho que para interpretar melhor até. [Silêncio]... Por que eu leio? Ah, não sei... é um... [silêncio]... é importante porque é um recurso que eu tenho, que eu preciso ter para a vida. Tipo, sem leitura, sei lá... ah, não sei explicar.

Penélope: Serve, serve para você escrever melhor, falar melhor, se expressar melhor, adquirir conhecimento, ver novas formas de, como eles dizem, sobre a vida, filosofia. É muito importante. Eu leio porque eu quero me tornar... ter bastante conhecimento das coisas, né? Ter mais sabedoria. Acho que um bom leitor, ele procura sempre estar se atualizando e também procurando discutir com outras pessoas o que elas acham daquela leitura, e estar se atualizando, conhecendo mais... um bom leitor é isso. Acho que eu sou mais ou menos uma boa leitora [ri sem graça]. Porque é agora que eu tô começando a ler mais, os grandes autores, o João Guimarães Rosa, Platão... Eu tô começando a 
ler agora, então eu não me considero uma boa leitora. Mas procurando... procurando conhecer mais.

Entendemos, pois, que a leitura, para os educandos, tem importante papel no desenvolvimento da habilidade de pensar, interpretar e, assim, adquirir conhecimento. $\mathrm{O}$ ser um bom leitor também está diretamente relacionado a esta capacidade de interpretação; portanto, o bom leitor seria aquele que entende, que sabe explicar o que leu, que guarda na memória o que leu e que presta atenção.

\section{[26-04-2007] - Entrevista}

Pesquisadora: Você se considera um bom leitor? Por quê? O que é um bom leitor?

Tiago: Bom leitor? Não. Deixa eu tentar explicar... [silêncio extenso] entendeu? Bom leitor, você diz como assim?... Bom leitor... bom, para mim um bom leitor é aquele que lê, absorve o que leu e sabe interpretar melhor, interpretar bem, eu acho que isso é um bom leitor.

Pesquisadora: E você não interpreta bem?

Tiago: Ah, eu não guardo nada do que eu leio. Eu esqueço logo depois.

Somente uma aluna relacionou diretamente a leitura a habilidades de escrita:

Penélope: Serve, serve para você escrever melhor, falar melhor, se expressar melhor, adquirir conhecimento, ver novas formas de, como eles dizem, sobre a vida, filosofia. É muito importante.

Podemos perceber que os alunos não estabeleceram uma relação entre a leitura e o "encantamento" / prazer, como vimos anteriormente no discurso da ONG e do educador. Aqui está expresso, pela voz dos alunos, o problema metodológico do projeto e o seu fracasso em constituir leitores: para eles, a leitura não serve também para se divertir, se encantar, ter prazer. Há ainda por parte dos alunos um olhar unicamente pragmático em relação à leitura. Na busca da constituição de leitores, é este o olhar que precisa ser transformado. $\mathrm{O}$ único momento em que se esboçou um direcionamento do olhar neste sentido foi na seguinte entrevista: 


\section{[10-05-2007] - Entrevista}

Pesquisadora: Você se considera um bom leitor? Por quê? O que é um bom leitor?

Cauê: Mais ou menos. Às vezes eu não entendo algumas coisas, tenho que reler, entendeu? O bom leitor é aquele que entende. Vai lendo, vai lendo, por mais que seja rápido, ele entende tudo, se prende naquilo. Às vezes, eu tô lendo e nem presto atenção, eu tenho que ler duas páginas de novo, porque eu estava pensando em outra coisa, sabe? Um bom leitor é aquele que se prende naquilo.

Pesquisadora: Mas $100 \%$ do tempo? Porque, às vezes, acontece da gente ter uns devaneios no meio da leitura. Em geral você lê e entende?

Cauê: Entendo.

Pesquisadora: Você não se considera um bom leitor porque você tem essas escapadas?

Cauê: Às vezes, eu não entendo algumas palavras também. Não, não é que eu não sou bom, eu não sou BOOOOOM. Eu sou bom, mas não um bom assim. Tem algumas coisas que eu não entendo.

Pesquisadora: Porque você lê?

Cauê: Não sei [ri]. Às vezes porque eu gosto. Algumas leituras para me divertir mesmo, para passar o tempo. E têm aquelas que você quer ler, não sei explicar, acho interessante, começo a ler e você prende naquela leitura. Às vezes eu começo a gostar e você se prende. Porque a leitura é uma lição de vida, às vezes.

Nesta entrevista com Cauê, o que nos chamou a atenção foi o fato de ele ter sido o único educando a afirmar que lia por prazer, "para passar o tempo, para me divertir".

Encontramos na sua fala e na de outros alunos, outro elemento importante: um problema de auto-estima em relação à leitura. Do grupo todo, apenas Tais afirmou ser uma boa leitora. Isso nos leva a perguntar em que medida o trabalho com a leitura na escola tem contribuído para instaurar este sentimento de impotência e incompetência diante do texto escrito. E se o projeto da ONG tem ajudado ou não a melhorar este sentimento. 
Concluímos que a questão fundamental na maneira como os educandos encaram a leitura está no fato de ela representar para eles apenas um instrumento de conhecimento e até de auto-conhecimento, mas não também uma fonte de fruição e entretenimento. O gosto e o interesse pela leitura, objetivo principal do projeto da ONG, não aparecem nas falas dos educandos e sua ausência pode ser um indicativo de anos de trabalho pedagógico infrutífero nas escolas, mas também do problema metodológico dos "círculos", visto que, mais uma vez, a ONG foca-se na constituição da identidade e na auto-análise mais do que no trabalho com a leitura propriamente dita, apesar dos esforços do educador Renato.

\subsection{PRÁticA: PROPOSTA DE TRABALHO E METODOLOGIA DO PROJETO “CÍRCULO DE LEITURA” - (entrevistas, observações e documentos)}

A metodologia do círculo existe, segundo uma de suas coordenadoras, "desde sempre", uma vez que, para os educadores da ONG, "o conhecimento está no universo". Porém, com as diversas experiências e novas idéias que vão surgindo, o método vai sendo, pouco a pouco, aperfeiçoado.

Antes de iniciarmos a exposição detalhada da metodologia do projeto, propomos o quadro a seguir com o intuito de apresentar brevemente alguns pontos principais (Figura 05).

Como informado anteriormente, cada educando do projeto ganha seu próprio livro, ou cópia (se for um conto), para manusear e fazer anotações, além de um caderno pautado e uma brochura com uma coletânea de poesias. Nos círculos que ocorrem na sede, disponibiliza-se, no centro, um porta-lápis com canetas.

A partir do quadro (Figura 05) percebemos que há preferência em se montar grupos pequenos, pois a ONG percebeu que os encontros realizados com um número restrito de participantes (até 10) têm rendimento diferenciado, uma vez que, em grupos menores, há mais espaço para que os educandos participem e se expressem, inclusive os tímidos. Na primeira visita realizada observamos: 
Para dar início à leitura, as educadoras dividiram os educandos em três grupos, um de 8 , e dois de 7 integrantes. A própria divisão do grupo pareceu-nos uma boa estratégia. Grupos menores permitem que mais alunos possam se expressar, o que, por vezes, tornou a discussão mais intimista.

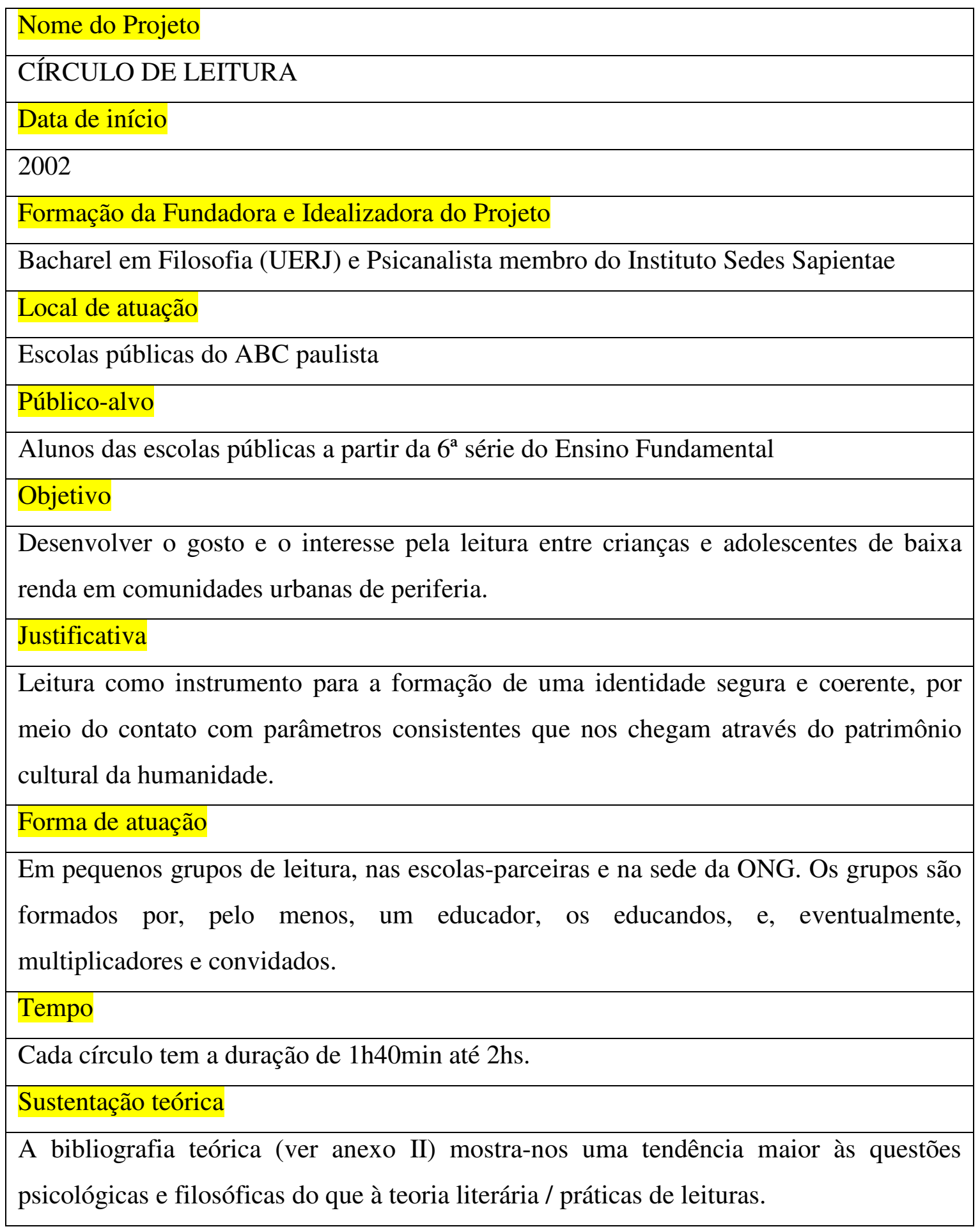

Fig. 05 - Pontos principais do Projeto "Círculo de Leitura" 
Assim, a leitura é realizada em pequenos grupos, tanto na sede quanto nas escolas. Na sede, após as leituras em pequenos grupos, estes se reúnem, em um único grande círculo, para compartilhar as impressões que tiveram e as questões levantadas em cada grupo, enriquecendo ainda mais a discussão. Já nas escolas, estas trocas ocorrem quando alguns alunos são convidados a participar de grupos em escolas diferentes, existindo uma espécie de intercâmbio de educandos.

Esta troca de idéias torna o círculo ainda mais rico, e ocorre com frequiência durante o desenrolar do projeto nas escolas do ABC. As coordenadoras acham muito importante que os participantes possam aumentar sua visão e perspectiva, ao se relacionarem com outros grupos, em outros ambientes. A própria visita semanal à sede da ONG, às sextas-feiras, também proporciona esta troca, pois são educandos de diferentes escolas que vêm para a sede participar dessas leituras e, depois, levam os temas que foram discutidos para suas escolas. Em geral, há sempre uma leitura-piloto na sede antes de se levar os textos para as escolas.

A viagem, subsidiada pelo projeto, que os educandos do $A B C$ fazem para São Paulo às sextas-feiras e aos sábados, também é um elemento importante. Segundo Carina, estas "viagens" ajudam a expandir os horizontes dos educandos, mostrando que a barreira que aparentemente existe entre o $\mathrm{ABC}$ e a capital pode ser transposta e que é possível pegar um ônibus e vir até S.Paulo para participar de um evento cultural ou de um encontro; mais que isso, que vale a pena sair de casa.

Todo este movimento de educandos que ocorre entre os diversos círculos promovidos pela ONG 6 não só colabora com a abertura de horizontes culturais e intelectuais, defendida por Carina, como promove principalmente a sociabilidade dos jovens - algo que eles apreciam muito no projeto: a oportunidade de conhecer outros educandos e convidados/palestrantes especiais.

Nos grupos, os educandos sentam-se em círculo, e a leitura em voz alta se inicia por algum voluntário, freqüentemente o próprio educador, que lê um parágrafo, algumas 
frases ou até uma página inteira, dando a vez a outro participante do círculo, em sentido horário.

É clara a intenção da ONG em distribuir os educandos em círculos ao invés de recriar um espaço de sala de aula/enfileirados ou mesmo colocá-los em um espaço retangular. Naturalmente, o círculo/ a "távola redonda" representa um espaço de igualdade e de participação, no qual todos se vêem e todos podem ser ouvidos facilmente. O diálogo buscado pela ONG a partir da literatura deve ser este espaço de igualdade e de valorização do indivíduo para que haja produção de conhecimento.

Neste caso, a leitura em voz alta nos círculos tem a mesma função que tinha séculos atrás, na época do Antigo Regime até o início do século XIX, como nos explica Roger Chartier (1999, p.142-143):

(...) ler em voz alta era uma forma de sociabilidade compartilhada (...) A leitura em voz alta alimentava o encontro com o outro, sobre a base da familiaridade, do conhecimento recíproco, ou do encontro casual, para passar o tempo. (...) A leitura em voz alta foi também vivida como uma forma de mobilização cultural e política dos novos meios citadinos (...) alimentava uma relação entre o leitor e a comunidade dos próximos.

Tendo isto em mente e buscando criar um espaço seguro e agradável para os educandos, os educadores afirmaram que não forçam ninguém a ler, procurando não causar bloqueios ou inibição. Fica determinado, desde o início, que não se pode rir do erro dos outros, uma vez que "nós todos estamos sujeitos ao erro". Os educadores possuem uma atitude bastante positiva no auxílio aos educandos quando lêem em voz alta e fazem tudo para manter um ambiente seguro e agradável, mantendo sempre uma unidade no grupo.

\section{[12-04-07] - Leitura do conto "Seqüência"}

Natália estava lendo com dificuldades

Natália: "Latidos, noutra parte, faziam-na entra outra...".

Renato: entrar oculta... 
Natália: entrar oculta no cerrado...
$[\ldots]$

Natália: "Légua adiante, entanto, nos Antônios, desabalava em golpe..." Cauê: Galope...

Renato: Galope. Vamos devagarzinho que a gente consegue...

Natália: Espandonga...

Renato: Toda espandongada, toda desengonçada...

Antes da leitura, é interessante notar que fica também estabelecido no grupo tanto aquele que deve fazer as anotações no "diário do grupo", o "escriba", que é o responsável por anotar as idéias mais interessantes que forem surgindo no decorrer dessas discussões, bem como aquele que será o responsável por abrir a porta (na sede) se alguém tocar a campainha. A esse respeito, fizemos o seguinte comentário:

Achamos muito interessantes estes acordos, pois evita que distrações ocorram, principalmente em relação à chegada posterior de outros participantes, os educandos não se distraem para decidir quem deve abrir a porta, uma vez que o assunto já foi discutido. Estes pequenos detalhes, metodologicamente, parecem fazer bastante diferença no "fluxo" da leitura.

A interrupção da leitura também é livre. Ou seja, quando algum participante quiser fazer algum comentário, pergunta ou observação, está livre para se expressar a qualquer momento. Assim, a cada interrupção, surge uma nova discussão interessante que pode durar bastante tempo, pois uma idéia leva a outra e se origina o que o projeto chama de fluxo de idéias. Terminado o debate, continua-se a leitura.

Após a leitura dos textos, em alguns encontros, é dado um tempo (em geral 15 minutos) para que os participantes escrevam suas impressões sobre a leitura feita. Neste momento, é distribuída uma folha para cada um. Em eventuais encontros, alguns educandos produziram poesias também. Anotamos em nosso diário: 
Jéferson, 15 anos, nesta $6^{a}$ feira, durante as atividades de escrita aproveitou para compor o seu próprio poema relacionado ao tema que havia sido discutido durante a leitura e se propôs a ler sua produção. Ele fez sua leitura e foi elogiado, sentindo-se muito orgulhoso.

Quando há tempo, a coletânea de poesias é utilizada nos fechamentos dos encontros. As poesias são lidas em voz alta pelo grupo, porém sem uma ordem estabelecida, cada participante lê um verso no momento que quiser, o que causa uma leitura bastante interessante com vozes sobrepostas. A leitura das poesias, em geral, é feita mais de uma vez, a repetição é justificada na proposta da ONG:

Ao final de cada atividade de leitura lemos uma poesia em voz alta, repetidas vezes, para que possamos apreender sua sonoridade, musicalidade, seu ritmo [...] utilizamos o ritmo da criação poética como agente de sedução para que os jovens fiquem impregnados das palavras dos autores, que o som das palavras ressoe dentro de cada um [...] incentivamos os participantes a decorar suas poesias preferidas, pois acreditamos ser isto um instrumento para adquirir conhecimento. Além disto, uma poesia é fácil de ser memorizada. Esta prática também tem a função de nos ensinar a respirar e fazer pausas ao falar.

Presenciamos, em alguns encontros na sede, os educadores propondo aos participantes que lessem uma poesia da coletânea antes de dormir, a fim de que o texto entrasse nos seus sub-conscientes durante a noite, o que poderia ajudá-los a decorar. Em um momento, uma das coordenadoras afirmou que a importância de se decorar os poemas residia no fato de que, segundo ela, no instante em que memorizamos a poesia, esta se torna parte de nós.

Infelizmente, nossas observações demonstraram que a leitura de poesia é feita raramente. Em geral o tempo é curto para a leitura de um conto ou, às vezes, com o prolongamento das discussões, o "círculo" termina antes que se possa chegar até ela. A postura metodológica da $\mathrm{ONG}$, referente à leitura de poesia, mais uma vez, minimiza o 
trabalho de constituição de leitores, pois não há tempo assegurado para tal em todos os encontros.

É preciso ressaltar que a poesia é, geralmente, só lida, não se discute o seu conteúdo nem a sua forma. Há boas intenções quando procuram trabalhar a musicalidade e a sonoridade da poesia, mas a repetição em voz alta não tem se mostrado suficiente para que haja entendimento, nem se desperte com isso o prazer emocional e muito menos o prazer estético. A poesia, por sua constituição e elementos, tende a ser um pouco mais hermética do que a prosa, e sem um direcionamento, permanece incompreendida pelos educandos e, portanto, não dialoga, nem transforma.

Apresentamos na Figura 06 um quadro que busca resumir os passos das atividades realizadas nos "círculos".

\begin{tabular}{|c|c|}
\hline PASSO 1 & Divisão em pequenos grupos. Os participantes sentam em círculo. \\
\hline PASSO 2 & $\begin{array}{l}\text { É definido quem será o "escriba” e o responsável pela logística (abrir } \\
\text { a porta, buscar papel, canetas etc.). }\end{array}$ \\
\hline PASSO 3 & $\begin{array}{l}\text { Início da leitura - começa por um voluntário e segue no sentido } \\
\text { horário. Discussões. }\end{array}$ \\
\hline PASSO 4 & $\begin{array}{l}\text { Eventualmente, há a reunião de grupos para uma troca mais ampla de } \\
\text { idéias surgidas do texto, momentos de produção escrita e leitura das } \\
\text { produções escritas. }\end{array}$ \\
\hline PASSO 5 & Leitura em voz alta de poesias. \\
\hline
\end{tabular}

Figura 06 - Passos das atividades realizadas nos "Círculos"

Em 2006, com a experiência adquirida em quatro anos de trabalho, as coordenadoras propuseram algumas modificações no projeto. A partir desta data, decidiram produzir um roteiro de leitura para cada texto literário trabalhado, com o intuito de orientar educadores e multiplicadores que, por vezes, se perdiam na leitura com seus grupos e passavam um tempo improdutivo em devaneios.

Sendo assim, agora foi estabelecido um calendário que também determina o número de encontros necessários para a leitura de cada texto. Quem elabora estes 
roteiros de leitura são Paula e Carina, as coordenadoras do projeto, e duas professoras de literatura, voluntárias. Muito do que está nestes roteiros surgiu também dos círculos de leitura ocorridos na sede da ONG com os educandos-destaques e educandosmultiplicadores do projeto.

Entendemos, por um lado, a necessidade de melhor direcionar seus educandos (uma vez que não são especialistas nem em literatura, nem em práticas de leitura), mas, por outro lado, os "roteiros de leitura" podem acabar funcionando como "apostilas" e aí sim "engessar" as discussões. A ONG anteriormente havia adotado uma postura contrária às críticas literárias, sendo elas, sob o seu ponto de vista, "um desvio da obra, o enrijecimento de uma determinada opinião sobre ela (...) uma estrutura paralela que afasta (os leitores inexperientes)". Perguntamo-nos, então: o que são estes roteiros de leitura? Ao contrário do que a crítica literária faz (ampliar o campo de discussão), os roteiros enrijessem, pois seu próprio nome remete à idéia de que há só um caminho a ser seguido, como se só existisse uma leitura, do que naturalmente discordamos. Chartier (1999, p. 77) nos lembra que:

\footnotetext{
A leitura é sempre apropriação, invenção, produção de significados. Segundo a bela imagem de Certeau, o leitor é um caçador que percorre terras alheias. (...) Toda a história da leitura supõe, em seu princípio, esta liberdade do leitor que desloca e subverte aquilo que o livro pretende impor.
}

Não somos contra os roteiros, pois observamos que há educadores que precisam de direcionamento ou de algumas idéias para discussão, porém atentamos para o cuidado que se deve ter ao utilizá-los, posto que, se empregados de forma inadequada, podem restringir ainda mais o trabalho realizado na ONG e tornar as leituras impostas, como critica Paulo Freire (2006, p. 20):

as palavras devem vir carregadas de significação de sua (do educando) experiência existencial e não da experiência do educador.

A outra mudança feita no ano de 2006 foi a diminuição dos encontros dos multiplicadores e educandos-destaques na sede da ONG em São Paulo. Anteriormente, em todas as sextas-feiras e sábados eram realizados encontros e círculos de leitura na sede. Porém, as coordenadoras decidiram transformar estes encontros semanais em 
encontros quinzenais, e, segundo Jurema, esta mudança foi positiva, pois permitiu que os educandos tivessem mais tempo para "digerir" as discussões da semana anterior, uma vez que cada encontro fornece uma gama muito grande de informações. Além disso, os educandos podem escrever seus diários (nos quais relatam os encontros e os assuntos discutidos para utilizarem nas escolas). A sede continua recebendo, nas datas marcadas, convidados especiais para círculos de leitura e os educandos-destaques das escolas de São Bernardo do Campo.

\subsubsection{TEXTOS ESCOLHIDOS}

No projeto "Círculo de leitura", são os coordenadores e educadores que escolhem os livros a serem trabalhados, restringindo-se aos que eles consideram como clássicos.

Inicialmente, há um círculo de leitura feito só com os educadores, no qual são levantadas questões do texto para serem levadas aos educandos, bem como são realizados os roteiros de leitura. Segundo a ONG, os livros são escolhidos pelo tema e não pela forma literária, pela sua construção: a preocupação primeira dos círculos é o contato com a história e não com a composição ou o lugar desta obra na literatura ou, ainda, com suas qualidades literárias. O saber contar a história é o ponto chave da metodologia, pois, quando "o saber está no corpo, é possível partir para o segundo plano de pensar nesta história”. Nas palavras de Jurema:

a gente não está interessado em críticos, como por exemplo o Saramago, que tem uma linguagem própria dele, mas não é a forma da linguagem dele que a gente está interessado, é justamente o que esta história pode fazer você pensar, o que isso vai contribuir para a sua história, que diálogo você vai estabelecer com o texto, mas é claro que surge, tem uma pessoa que sabe dos dados, com alguma informação sobre Saramago... isso é sempre bem-vindo. 
Os critérios para a escolha dos textos demonstram mais uma vez a importância que a ONG atribui ao conteúdo e ao prazer emocional advindo do reconhecimento e da catarse do leitor; porém, ao excluir a forma, relega a segundo plano o desenvolvimento do prazer estético. Lembramos que se a ONG está trabalhando com o leitor crítico, de Nelly Novaes Coelho (2002, p. 40), apresentado no item 3.2.2, é preciso levar em conta que:

O convívio do leitor crítico com o texto literário deve extrapolar a mera fruição de prazer ou emoção e deve provocá-lo para penetrar no mecanismo de leitura. O conhecimento de rudimentos básicos de teoria literária faz-se necessário; pois a literatura é a arte da linguagem e como qualquer arte exige iniciação.

Há evidentemente uma busca da ONG pelo "seguro", por aquilo que já foi reconhecido como "clássico" e com valor literário (evidentemente que o que determina este valor é sua qualidade estética, que pode ser apreciada quando se tem desenvolvido o senso estético - o mesmo que não é trabalhado no projeto da organização).

A decisão de escolher as obras clássicas foi defendida pela ONG nos seguintes termos:

Escolhemos obras daqueles escritores que conseguiram entrar em contato com as profundezas da alma humana, colocando no papel este universo imenso que é o homem (...) São aqueles que retomam temas universais, que sobrevivem ao tempo (...) Para os círculos escolhemos estas obras, que nos possibilitam retomar estes temas, recomeçar pelos fundamentos, pelas origens. As histórias que escolhemos têm o dom do encantamento, do deslumbramento. (...) Como os sonhos, os mitos se utilizam de imagens simbólicas, que não são apenas do sonhador, mas pertencem a um patrimônio coletivo, à rica experiência da humanidade. (...) Assim, valorizamos os clássicos da literatura porque eles oferecem ao jovem um repertório de temas e valores que o apóiam na transição para a vida adulta, permitindo-o 
relacionar dilemas e situações do dia-a-dia com temas, heróis, valores, idéias e condutas que sobrevivem ao tempo.

O que pode ser questionado neste sistema de escolha dos livros não é somente a restrição a textos clássicos, mas, sobretudo, o fato de não haver participação dos educandos neste processo. Sabemos que é papel do educador direcionar as chamadas "leituras anárquicas" dos jovens (discutidas no item 3.2.2) e proporcionar um contato dos educandos com leituras de valor estético reconhecido, direcionando-os para um outro universo. Porém, como afirmamos anteriormente, o processo de escolha de material de leitura deve ter em vista não só o valor estético das obras, mas também o público a quem se destina.

Segundo Jurema, há momentos em que os educandos propõem textos. Ela ressaltou que o projeto está aberto às sugestões de leitura, mas o seu próprio discurso a contradiz quando afirma que, em geral, os coordenadores acabam se mantendo dentro do repertório clássico que eles escolheram, uma vez que, para eles, este é um repertório muito bem pensado e refletido, e os textos sugeridos pelos educandos, freqüentemente, não se adequam ao projeto, não são o que pretendem discutir. Assim, sutilmente dizem que não é possível a discussão do texto no grupo, mas que, se quiserem compartilhar com outra pessoa, é possível eles criarem seus próprios grupos de discussão.

O problema aqui está exatamente nas palavras de Jurema: “os textos sugeridos não se adequam ao projeto". Perguntamos então se não seria o contrário: não deveria o projeto buscar se adequar aos seus educandos e aos temas que eles querem discutir e não impor discussões que nem sempre interessam a eles?

Esta imposição de textos, sem diálogo, sem levar em consideração o universo do outro pode estar fadada a fracassar. É preciso um conhecimento mínimo do outro com quem se dialoga, se não, não existe um diálogo que leva ao conhecimento e, sim, um monólogo que o outro não entende ou pelo qual não se interessa.

Pareceu-nos haver um enrijecimento dos coordenadores em relação à colaboração dos participantes na escolha dos livros, repetindo de certa forma o que acontece na escola: a falta de conhecimento por parte dos professores/educadores sobre 
quem são os leitores com quem buscam trabalhar, quais são seus universos culturais e horizontes de expectativas.

Deve-se levar em consideração também que os educandos atendidos pela ONG de hoje estão, na realidade, mais próximos do leitor fragmentado e movente (alguns caminhando para o leitor virtual) do que do leitor contemplativo/meditativo e isso requer uma outra abordagem e diferentes escolhas de livros.

Segundo Santaella (sem data), o leitor contemplativo é aquele leitor da era préindustrial, do livro e da imagem expositiva que

(...) não sofre, não é acossado pelas urgências do tempo. Um leitor que contempla e medita. (...) é o leitor que os procura, escolhe-os e delibera sobre o tempo que o desejo lhe faz dispensar a eles (...) Um livro, um quadro exigem do leitor a lentidão de uma dedicação em que o tempo não conta.

Sendo o leitor fragmentado e movente, um filho da revolução industrial, dos centros urbanos:

(...) É o leitor apressado de linguagens efêmeras, híbridas, misturadas.(...) nasce com o jornal um tipo novo de leitor, o leitor fugaz, novidadeiro, de memória curta, mas ágil. Um leitor que precisa esquecer, pelo excesso de estímulos, e na falta do tempo de retê-los. Um leitor de fragmentos (...) A cidade começa a se povoar de signos (...) Esbarrando a todo o instante em signos, signos que vêm ao seu encontro, fora e dentro de casa, esse leitor aprende a transitar entre linguagens, passando das coisas aos signos, da imagem ao verbo, do som para a imagem (...) Isso se acentua com o advento da televisão.

Tendo em vista estes diferentes tipos de leitores, quando se pensa em constituição de leitores contemplativos/reflexivos é preciso começar com outra linguagem e, sobretudo, com temas atuais/juvenis que se relacionem com a vida destes educandos, para então encaminhá-los à leitura dos textos clássicos. Talvez uma forma de começar a direcionar estes leitores moventes no sentido de se tornarem leitores contemplativos seria a ONG centrar-se naquilo que a literatura infantil e juvenil tem para oferecer, especialmente com os educandos na faixa dos 11 aos 14 anos. Naturalmente que "Fernão Capelo Gaivota" ou "O pequeno príncipe" oferecem conteúdo para a discussão sobre amizade, por exemplo, porém a sua forma não é, a 
princípio, apelativa aos alunos de hoje e não os seduz. A forma e a linguagem deles são outras: se buscassem trabalhar o mesmo tema com livros de Ziraldo, Ricardo Azevedo, Ana Maria Machado, talvez o projeto fosse mais eficaz na constituição de leitores.

O repertório do projeto também não é muito extenso, há momentos em que um convidado traz um novo livro, porém, a intenção do projeto, de acordo com as coordenadoras, é concentrar-se em poucas obras e trabalhá-las profundamente, sendo comum o que chamam de revisitar a obra, fazendo re-leituras. Por vezes, terminam o ano com a leitura do primeiro conto que leram juntos, pois esta se torna uma leitura completamente diferente, o que permite avaliar o desenvolvimento do educando, do seu olhar, o que é uma forma de avaliação bastante positiva.

Há também por parte da ONG uma preocupação com os temas que cada leitura traz consigo. As coordenadoras do projeto buscam sempre leituras que consideram "edificantes", em oposição a leituras violentas e "pessimistas". Acerca deste assunto, segundo Jurema, o projeto sabe que a realidade em que vivem muitos dos seus participantes já é muito dura, evitando-se, assim, a possibilidade de que as leituras os "deprimam" mais ainda.

Este é um assunto delicado que pode ser contestado por muitos. Podemos até mesmo afirmar que certas escolhas promoveriam a alienação, fornecendo uma falsa realidade, um mundo de Poliana. É algo controverso, mas consideramos que tudo pode ser lido e principalmente que se pode direcionar as reflexões e discussões para uma finalidade edificante, é preciso tirar o rótulo de "excluídos" dos educandos e deixar fluir a leitura, diferentes leituras.

No entanto, é compreensível esta posição da organização e a apoiamos na medida em que ela busca genuinamente a reflexão dos educandos. Entendemos esta escolha, pois o projeto se propõe a criar um "espaço de sonho, a liberdade do devaneio", promovendo um "encontro direto com a magia e com a arte". Sendo assim, as escolhas de leitura do projeto levam sempre em consideração a construção da auto-estima de seus participantes. 
A lista de alguns títulos escolhidos é a que se segue:

- "Fernão Capelo Gaivota" - Richard Bach

- "A chave do tamanho" - Monteiro Lobato

- "O pequeno príncipe" - Antoine Saint-Exupéry

- "O Banquete" - Platão

- "A Odisséia" - Homero

- "A riqueza das nações" - Adam Smith

- “Grande Sertão Veredas" - João Guimarães Rosa

- "Primeiras Estórias" - João Guimarães Rosa

- "Autobiografia" - Benjamin Franklin

- "Dom Quixote" - Miguel de Cervantes

- "Otelo" - William Shakespeare

- "Romeu e Julieta" - William Shakespeare

- "Sidarta" - Herman Hesse

- "O velho e o mar" - Ernest Hemingway

- "Robinson Crusoe" - Daniel Dafoe

- "O conto da ilha desconhecida" - José Saramago

- "O Apólogo"; "O espelho" - Machado de Assis

- "A arte de ser feliz" - Cecília Meireles

- "O pintor, a cidade e o mar"; "O catador de pensamentos" - Mônica Feth

- "A menina e o pássaro encantado" - Rubem Alves

- "O afogado mais bonito do mundo" - Gabriel Garcia Márquez

- “A moça tecelã" - Marina Colassanti

- "Felicidade Clandestina" - Clarice Lispector

- "Boles" - Máximo Gorki

- "Vestida de Preto" - Mário de Andrade

- Excertos de "As três transformações do espírito" e "Assim falou Zaratustra" Friedrich Nietzche 


\subsubsection{GESTÃO DO TEMPO E PARCERIA COM A ESCOLA}

A partir das entrevistas realizadas com educandos-participantes do projeto e de observações feitas ao longo dos estágios realizados durante o curso de licenciatura em Letras na Faculdade de Educação, concluímos que, na sala de aula, o tempo dedicado à leitura é restrito e, por vezes, inexistente. Geralmente, os professores realizam atividades de leitura para preencher um espaço de tempo que restou no final das aulas. Há uma crença entre os professores de que ler em sala de aula é perda de tempo, uma vez que os alunos podem ler fora do tempo de aula, o que muitas vezes não acontece.

No projeto estudado, cada círculo de leitura acontece para que a leitura possa ser feita tranqüilamente em um período de duas horas, na sede da ONG e nos círculos que ocorrem fora do horário escolar, tempo ideal para o leitor imersivo do qual estamos tratando. A maior parte dos encontros acontece no período em que os educandos não estão estudando. Assim, quem estuda de manhã, participa dos círculos à tarde na escola e vice-versa.

No ano de 2006 houve uma grande mudança na organização do projeto. Isto porque, no ano anterior, a ONG realizou um projeto-piloto em uma das escolas de São Bernardo do Campo que havia pedido a realização dos círculos de leitura durante o horário de aula, ou seja, dentro da grade curricular. Assim, a ONG, em parceria com os professores de Português, começou a realizar várias oficinas de leitura com diferentes grupos da classe, até atingir $100 \%$ dos alunos do professor-parceiro. Passada esta primeira fase, a ONG e os professores, após observarem a iniciativa e vontade dos alunos, escolheram 15 alunos para montar um grupo de leitura por classe. Os alunos de maior destaque na discussão dos contos apresentados foram selecionados, o que, segundo a ONG, não impossibilitou a participação de um aluno de menor destaque que, no entanto, mostrou interesse pela atividade. Essa permanece sendo uma prática excludente, como já discutimos, uma vez que não está disponível para todos os alunos da escola igualmente.

O mais importante nisso tudo foi o fato da ONG integrar o horário de aulas, uma grande e importante conquista, na medida em que passou a interferir diretamente na grade escolar e na metodologia de trabalho dos professores. Outro ponto positivo foi 
que, colocando o círculo de leitura dentro do horário de aula, a evasão do projeto diminuiu bastante. Assim, toda semana, os professores de Português permitem que os 15 alunos selecionados participem do círculo de leitura em uma aula dupla (1h40).

Encontramos nesta ONG o que buscávamos na pesquisa de campo inicial com as outras cinco organizações visitadas: uma parceria real com a escola pública, na qual as práticas educativas da ONG são levadas para dentro da escola, buscando com isso uma verdadeira mudança no ensino público. No momento em que os círculos se ampliarem e atingirem todos os alunos da escola-parceira, aí poderemos afirmar que finalmente houve uma intervenção da ONG numa prática pública com o intuito de auxiliar o sistema e melhorar a qualidade do ensino público. E é isso o que buscávamos.

\subsection{RESUltado: ANÁlise DO PROJETO POR PARTE DOS PARTICIPANTES - (entrevistas e observações)}

Neste item procuramos, por meio de observações e entrevistas com os participantes do projeto, analisar a eficácia ou não das atividades propostas pela ONG no tocante à melhoria do grau de letramento, ao desenvolvimento do gosto pela leitura $\mathrm{e}$ à constituição de leitores. Para tanto, fizemos aos educandos as seguintes perguntas:

- O que você está achando das atividades do círculo de leitura?

- Você sente alguma diferença na sua forma de ler após participar do projeto?

- Você está lendo mais depois de participar do projeto?

\subsubsection{OS EDUCANDOS E SUA RELAÇÃO COM O PROJETO E COM O DESENVOLVIMENTO DA LEITURA}

Tendo em vista o levantamento de dados obtidos, percebemos que a participação nos círculos de leitura tem revelado uma melhora na auto-estima dos educandos em relação à leitura, e na forma com que agora abordam um texto. Em geral, a questão da interpretação foi a que mais apareceu no discurso dos educandos: 
Laura: Sei lá, gostei muito... Tipo em voz alta, tinha vergonha, não deu pra perder a vergonha totalmente, mas foi bom. Ajudou a desenvolver a minha mente, fiquei sei lá, com a mente mais aberta, assim, em relação às outras pessoas que eu via lendo, "mó" espontânea ali, explicando, entendeu? E hoje eu já sei ler uma coisa e explicar para as pessoas... porque nem todos têm a mesma visão. Por exemplo, eu leio uma coisa e já imagino uma coisa, e outra pessoa lê e imagina uma coisa totalmente diferente, isso me ajudou muito...

Taís: Tô achando legal. Mudou o meu jeito de ver a leitura, a gente aprende a pronunciar as palavras melhor, a conviver em grupo, a entender as idéias das outras pessoas. [...] Depois do círculo de leitura eu comecei a ver o modo de ler diferente, porque antes era só uma leitura, mais uma estória, e agora, depois do círculo de leitura, eu vejo que não é MAIS só uma estória, é uma estória que quer passar alguma coisa para as pessoas.

Cauê: Estou gostando bastante. Então, o que eu falei de interpretação, consegue ficar bem mais fácil, você aprende aqui a interpretar.[...] depois do círculo de leitura você começa a prestar mais atenção nos mínimos detalhes que nem dava bola, eu presto mais atenção.

Tiago: Eu tô pensando mais. Antes eu lia só por ler, não conseguia absorver o que estava passando. Agora é melhor.

Penélope: Muito legal! Porque é uma coisa muito diferente assim, da escola, né? Não é aquela coisa: você vai ler literatura, desse jeito... e ponto. É uma coisa que você pode discutir, debater, você pode expor a sua idéia para a pessoa. É muito legal. [...] (minha forma de ler) Mudou, mudou a interpretação. Eu não procuro ver aquilo ali que o texto acabou, eu procuro ter uma outra, o que o texto quer falar além daquilo. E se eu não consigo, eu leio de novo.

Há nos discursos dos educandos uma observação clara da transformação da leitura por obrigação ou só ligada ao prazer emocional em uma leitura mais cuidadosa, relacionada ao prazer estético e às mensagens que cada obra traz. Apesar do projeto não focalizar a questão do desenvolvimento do prazer estético e o trabalho com a estrutura dos textos, o fato de buscarem nos textos não a história, o enredo simplesmente, mas o conteúdo implícito na obra, auxiliou os educandos a darem um passo a mais em direção ao prazer estético que uma obra de arte pode proporcionar.

A passagem da mera decodificação de um texto para o diálogo com ele é a melhoria do grau de letramento que bucávamos nas atividades da ONG e que se mostrou efetiva neste grupo de alunos. 
O desenvolvimento do grau de letramento do grupo foi sendo construído a cada encontro com o uso de diversas práticas usadas pelo educador Renato, tal como a retomada do encontro anterior, na qual Renato foi instigando os educandos a recontar a história lida e, assim, aprenderem a parafrasear um texto, a atentar para os momentos mais importantes, a refletirem sobre porque alguns momentos são essenciais e o que querem dizer. A paráfrase dos textos ocorria no início dos encontros, quando retomavam o encontro anterior ou mesmo durante os círculos, para retomar o que estavam lendo e confirmar se os educandos estavam entendendo o que estava sendo lido.

\section{[29-03-07] - Retomada e paráfrase do encontro anterior}

Renato: $O$ que que a gente tinha falado de Prometeu e Epimeteu? Vocês lembram?

Taís: Por causa da coisa do fogo.

Renato: Fogo? Que coisa do fogo?

Taís: Que o poder do fogo era muito grande.

Renato: Muito grande, sim, mas que poder era este, né? É grande, sem dúvida, mas tem muitos poderes. Quais desses poderes grandes a gente quis explorar? Vocês lembram? (...) o que significava? O que que a gente deve ao fogo?

Penélope: A civilização.

Renato: A civilização. Basicamente o mito de Prometeu é que a gente deve ao fogo a civilização, mas não só isso (...) o fogo veio junto com o quê?

Taís: Com as divisões lá, foi Zeus que falou para Prometeu e Epimeteu darem qualidades para os seres vivos...

Renato: Para os animais também.

[Renato vai instigando os alunos a recontarem a história, direcionando e buscando detalhes; uma aluna liderou a paráfrase].

Taís: Quem foi mesmo que deu o fogo? Prometeu ou Epimeteu?

Renato: Prometeu.

Taís: Ele deu o fogo, a inteligência, a... 
Renato: Tudo isso ele deu? De uma vez? O que que ele trouxe pra cá? O que que ele roubou de Atenas?

Cavê: $O$ fogo.

Renato: $\bigcirc$ fogo mais...

Cauê: A inteligência?

Renato: A arte!!! Porque se você só der o fogo para o homem, né? é como dar uma tocha na mão de uma criancinha, né? Ela vai pôr o fogo em qualquer lugar, onde puder pegar fogo, ela vai pôr, porque é bonito, então ele pega também as artes, a habilidade disso. Aí, isso é suficiente para a humanidade conviver ou não? Foi suficiente? O que que faltava? O que que acontecia com os homens, você se lembra Tiago?

Tiago: Não tô lembrando não... [6 segundos de pausa]. A Política.

Renato: Isso! Porque faltava política. Quem entrega?

Tiago: É o... Zeus fala para entregar... como é que ele chama?

Taís: Hermes!!!

$[\ldots]$

Taís: Ah, tem esse negócio aqui (pega o texto e lê), Zeus fala no final: (...) todo homem incapaz de compartilhar do pudor e da justiça, deve ser entregue à morte, por ser um flagelo para a cidade.

Renato: O respeito e a justiça, portanto, são habilidades que todos têm, cada um dos mortais tem. Por isso esta sentença de Zeus, que teve como função organizar o cosmos. Superar a época dos Titãs e instituir a política. (...) Pensando então neste final que a Taís colocou, desta sentença dada por Zeus, é que eu trouxe então o texto do Guimarães Rosa, né? Que se chama "Os irmãos Dagobé" e acho que a gente pode discutir um pouco o que acontece quando os homens não zelam pelo dom da política, esse dom... o que é que pode acontecer... (...) Aí, se a gente se der bem com o Guimarães Rosa, com "Os irmãos Dagobé", então, semana que vem a gente já começa com o livro de onde foi tirado este texto, "Primeiras estórias".

Neste outro momento de paráfrase, realizado durante a leitura, Renato instiga os alunos a fazerem suas próprias anotações no livro, registrando comentários ou dúvidas como forma de começar assim a aprender a dialogar com o texto e torná-lo vivo. Aqui percebemos que os educandos ainda não apresentavam o costume de riscar o livro e 
ainda o viam como um objeto a ser reverenciado e não como algo seu que faz parte do seu conhecimento.

\section{[12-04-07] - Leitura do conto "Seqüência"}

[Após a leitura dos dois primeiros parágrafos]

Renato: Gente, dá para entender a estória? Ele espanta pela maneira como ele vai falando, não é?

Taís: Eu entendi que a vaca não era de ninguém.

Renato: É, mas ela está indo para umas terras... Fala...

Cauê: Ela tá indo, ela ainda não chegou, ela está passando...

Renato: É, e ela se faz de boba, de sonsa, finge que está pastando, né? Mas, fala naquele primeiro parágrafo que ela sabe muito bem para onde vai, ela "nem hesitava nas encruzilhadas", então ela pertence a algum lugar sim.

Cauê: Ela pertence a algum lugar, ela sabe onde é, mas está passando pelo caminho.

Renato: Mas, aqui fala: "reto a trazia, para o rio, e - para lá do rio - a terras de um Major Quitério, nos confins do dia, à fazenda do Pãodolhão". Ela tá indo para um lugar chamado Pãodolhão. Você ainda não sabe de onde ela saiu, mas tá claro isso né? Mas, marquem as coisas que vocês... não tenha dó de riscar livro, nem que seja à lápis, é importante se não a gente acaba se perdendo, escreve aí, mesmo pequenininho, depois a gente apaga, as idéias que vocês forem tendo, tá bom?

Cauê: É que é novo...

Taís: É, é tão novinho, cheiroso...

Renato: Ah, tá bom... Vamos lá.

[Em poucos momentos os alunos começaram a riscar seus livros - em geral sempre os mesmos - as garotas]

Além das paráfrases, outro mecanismo utilizado para a melhoria do grau de letramento dos educandos era a retomada das idéias discutidas no círculo como preparação para o texto que iriam escrever sobre o que havia ficado para cada um da leitura realizada. Esta retomada incluía, como no decorrer de todo o círculo, momentos em que o educador leva os alunos à reflexão e à interpretação do texto. 
[29-03-07] - Leitura do conto "Os irmãos Dagobé"

[Fim da leitura]

Renato: E aí?

Tiago: Era isso mesmo que eles queriam, ir cuidar da vida deles.

Renato: O que mais? Vamos ver?

Taís: Eles queriam ir para a cidade grande...

Renato: Vamos pensar nisso... o que significa a cidade grande?

Taís: Uma outra vida...

Renato: É, lá tem padre, tem autoridade...

Penélope: Quatro pessoas na cidade grande desaparecem.

Cauê: É porque lá eles iam ter que ficar neste sistema que o irmão tinha instituído, e eles não queriam isso. No outro lugar, era diferente, eles podiam ser outras pessoas. Um lugar que tem política. Você vai começar sua história lá. Ele pode falar "nunca matei ninguém".

Renato: É uma chance de ser, né?

$[\ldots]$

Renato: Vocês não acham que na fala do Liojorge tem alguma coisa que tocou os Dagobés? Quando ele estava explicando por que ele matou o irmão deles, a gente falou da estratégia... ele não tem nada a perder, mas tem uma coisa certeira que ele falou que eu acho que toca lá nos Dagobés...

Tiago: Desculpa.

Renato: Ainda não é isso. Desculpa, não é só desculpa, porque ele matou sem querer mesmo, né? Sim, ele vai pedir desculpas, no entendimento dos outros você está coberto de razão. Eu quero que vocês entendam que eu matei para preservar a minha vida, "por destino de desastre", mas neste momento ele fala uma outra coisa...

Taís: "Não tinha querido matar irmão de cidadão cristão nenhum".

Renato: Perfeito! O que isso significa? Porque cidadãos cristãos os Dagobés não eram. Não é verdade? Eu não quis matar irmão de cidadão cristão, ou seja, vocês que são cidadãos cristãos... ele está se referindo aos três vivos.

Taís: No final ele fala: "Moço, o senhor vá, se recolha. Sucede que o meu irmão é que era um diabo de danado..." 
Renato: O que é que você quer fazer com este pedaço? Eu sei que você sacou alguma coisa. Vamos lá. Acho importante. O Liojorge falou não queria matar irmão de cidadão cristão nenhum, e no final ele fala "nosso irmão é que era um diabo de danado"...

Taís: Acho que é porque ele sabe que os três não têm culpa de ser assim.

Renato: Fala Carla... Fala.

Tiago: O Liojorge sabia que os três irmãos não eram maldosos estava fazendo mais por conta das obrigações deles com o irmão. O Liojorge vê.

Carla: A gente não queria fazer o que ele impunha para a gente.

Renato: Pois é, mas cidadãos cristãos eles não eram mesmo, mesmo fazendo contra a vontade, eles eram "absolutamente facínoras", umas bestas-feras mesmo, sanguinários. Mas quando eu falo, "não queria matar irmão de cidadão cristão nenhum", parece que eu acendo a possibilidade de ele ser isso (...) Ninguém nunca falou isso para eles com certeza. Aí é que o Liojorge acertou. $O$ que mais gente?

Em um desses momentos de paráfrase, capturamos a magia da literatura, no desfrute do prazer estético, por um dos educandos, Tiago. É difícil descrever aqui o rosto de Tiago ao repetir algumas frases do texto, mas esperamos que a reprodução do diálogo possa representar um pouco deste momento.

\section{[19-04-07] - Leitura do conto "Seqüência"}

[Os alunos estão retomando o conto da semana anterior e contando para Tiago que não estava presente].

Natália: Estava anoitecendo.

Renato: É, estava tudo escuro. E a vaquinha vai, entra na água, só os chifres de fora, vai nadando e atravessa. Mas este rapaz, ele sente uma coisa, o que que ele sente para conseguir atravessar?

Penélope: Ter confiança...

Renato: Un-hum, e ele sente um desejo. A gente deu nome para isso, não deu? Está relacionada a querer...

Vários alunos: Querência.

Renato: Querência, né? Que ali naquele momento, é uma espécie de saudade. Na verdade, a querência... 
Taís: Coitado do Tiago, ele tá boiando... [vendo o rosto do colega]

Renato: Mas ele tá entendendo, você vai ver se ele não vai entender... ele está com essa cara de quem vai entender. Até aqui tudo bem, né Tiago? O Tiago é inteligente, ele tá entendendo. Então, Tiago, é o seguinte. Esse negócio de sair aí pelo mundo, mesmo sem saber ao certo, não é também assim que você SAI de qualquer jeito e tanto faz eu ir para a direita ou para a esquerda, pra cima ou pra baixo, não.

Tiago: Você sai atrás de uma vaquinha.

Renato: EXATO. O Tiago está certíssimo. Eu não vou sair... eu vou sair quando eu tiver uma vaquinha. Não sei para onde a vaquinha está me levando, mas só de saber que eu estou seguindo uma vaquinha, já é um rumo na minha vida, cê acha que não? Aonde a vaquinha vai eu não sei. Então, tem uma coisa que a gente não dá para explicar muito bem, mas você sente que é aquilo e você vai embora. Que é a querência, o desejo de um outro lugar. Aí essa vaquinha tá num lugar chamado "Pedra" e tá indo para o...

Cauê: PÃOdolhão.

Renato: Então ela sai da pedra para ir para o Pão. Então, você desconfiou...

Taís: Ela era de uma boiada muito...

Renato: Era um "gado de coração ativo".

Tiago: Coração ativo... [rosto iluminado, reflexivo]

Taís: Ela não era marrom nem preta. Ela era VERMELHA. E sai com o sol vermelho, tipo como camuflando.

Renato: Olha o Tiago... ele sentiu certas imagens, ele pegou e repetiu o que eu falei: "Coração ativo"... Ele sentiu o coração ativo.

[Tiago fica em silêncio com o olhar um pouco perdido e um leve sorriso nos lábios como se estivesse descobrindo algo belo]

[Taís ri]

Renato: $O$ que você acha que é um gado de coração ativo?

Penélope: Selvagem, não é?

Renato: Selvagem, pode ser. É, num é uma coisa assim, um gado qualquer.

Carla: Um coração que tem bondade e vontade.

Renato: Acho que é um gado que tem querência, né Carla? Ele tem vontade própria, então ele tem querência, é ou não é? Acho que é por aí. Não é de qualquer raça. 
Taís: Que capta o sentimento, coração ativo.

Renato: Acho que é isso mesmo, um coração que pulsa meio que com o ritmo do mundo. Acho que a gente pode pensar assim.

Tiago: Bonito isso...

$[\ldots]$

Renato: Quando eu falo que ele pulsa conforme o movimento do mundo dá a impressão de que é um gado que está em sintonia mesmo com essa coisa maior do universo, esse coração pulsando que te move no mundo, que você só com a inteligência, só com a razão você não consegue... só adivinhando mesmo, você sabe que tem que sair da Pedra e ir para o Pãodolhão.

Taís: Normalmente a vida te coloca dois caminhos, os dois podem ser bom ou ruim. Só com a intuição você sabe que caminho você vai tomar.

Renato: Então, segue o coração ativo, né? Tem corações que parecem pulsar com o mundo. Eu tô viajando. Semana passada, Tiago, a gente leu, marcou uns pontos, mas a idéia hoje era viajar nesse conto. A gente podia ler hoje de novo direto, só para relembrar algumas coisas e aí a gente volta na viagem. Qual é a página mesmo?

Apesar dos gráficos que seguem (Figuras 07 e 08), fornecidos pela ONG a partir de um formulário preenchido pelos educandos, mostrarem que os alunos afirmam ler livros fora das atividades dos círculos de leitura, isso não se mostrou verdadeiro na nossa pesquisa de campo. A hipótese que temos para esta discrepância de resultados é a de que no formulário da ONG, os educandos podem ter sentido a necessidade de darem respostas que fossem agradar ao projeto, nem sempre sendo sinceros nas suas respostas. 


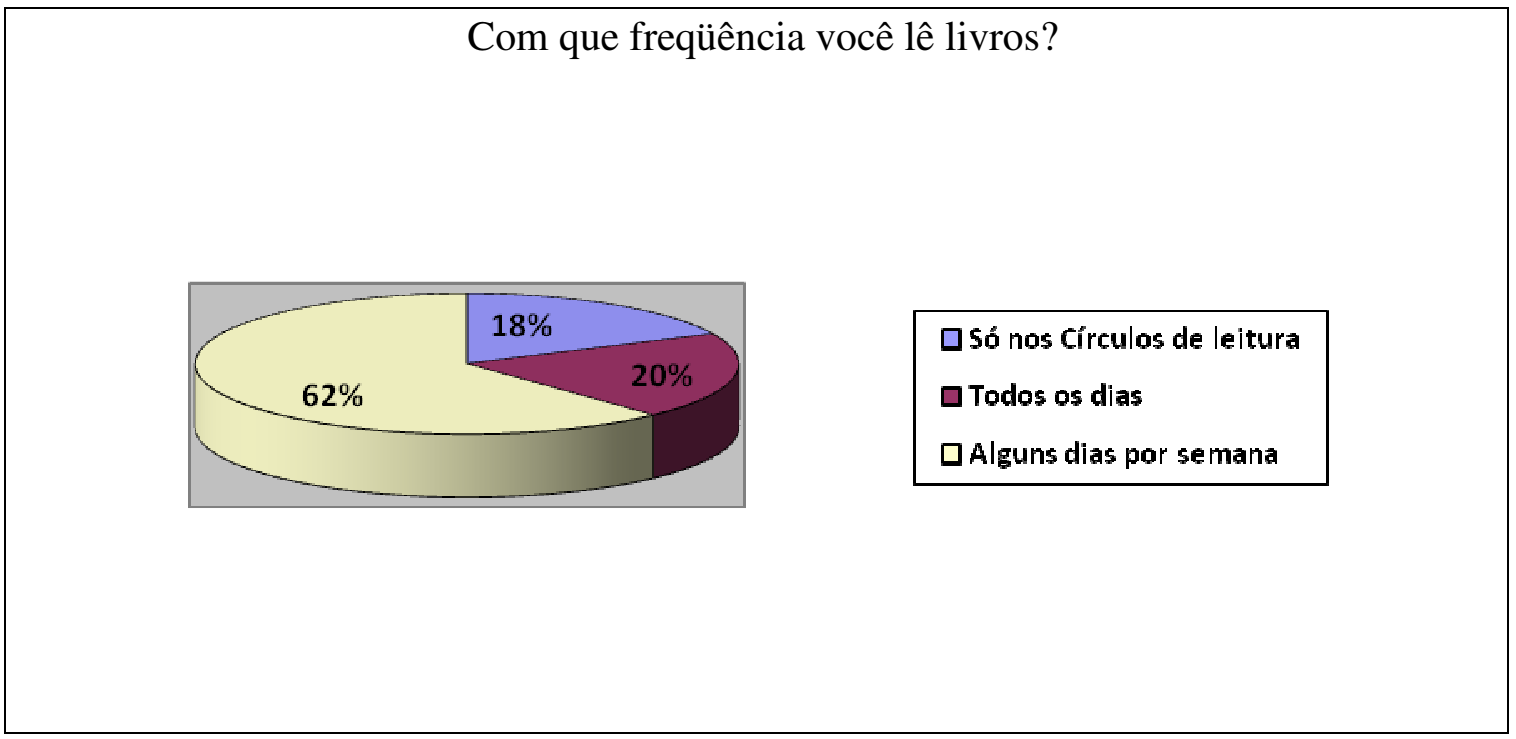

Fig. 07 - Dados resultantes do questionário inicial aplicado para 219 jovens no $1^{\circ}$ semestre de 2005

Com que frequiência você lê livros?

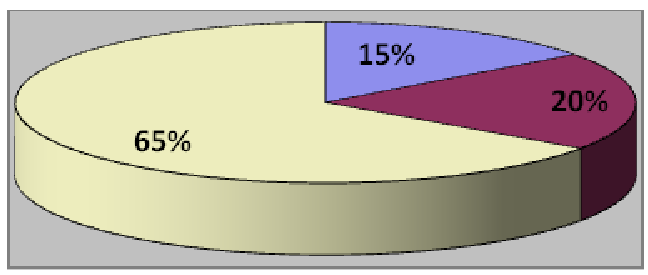

$\square$ Só nos Círculos

口Todos os dlas

$\square$ Alguns dias por semana

Fig. 08 - Dados resultantes do questionário inicial aplicado para 123 jovens no $2^{\circ}$ semestre de 2005

Em nossa pesquisa, a melhoria do grau de letramento nem sempre foi acompanhada pelo aumento na freqüência ou no volume de leitura realizada pelos educandos. Em geral, os educandos afirmaram não ter tempo para ler fora dos círculos. A maior parte deles permanece só com a leitura feita nos encontros e raramente lêem por conta própria, mesmo o material lido em grupo. Quando afirmam ler, de modo 
geral, são os textos do projeto; raríssimos são aqueles que começam a ler mais, e a ler materiais e livros que não estão no projeto.

Laura, aluna participante do grupo de Renato, afirmou estar lendo mais, porém, depois, afirmou que não tinha muito tempo para retirar livros da biblioteca:

Pesquisadora: Você tem lido mais depois que começou a participar do projeto?

Laura: Tô, tô lendo mais, bem mais. As coisas que estão no círculo, qualquer coisinha que eu vejo eu já me interesso para ler. [...] Só vou na biblioteca quando eu vou fazer trabalho mesmo. É muito difícil, eu não tenho tempo mesmo. Antes de trabalhar eu ia bastante, nesta da escola.

Os outros educandos participantes do grupo de Renato deram as seguintes respostas para a mesma pergunta:

Taís: Leio. Agora, depois do círculo, eu leio mais. O livro do Guimarães eu não tenho lido fora do círculo não. Mas quando eu li o José Saramago, a "Ilha desconhecida", eu lia em casa antes e lia depois de novo. O do Guimarães agora eu não tô lendo, porque eu tô muito sem tempo. Eu jogo handball pela escola, e agora eu tô tendo jogo, treino, e época de prova.

Cauê: Alguns dias eu pego para ler sim. Eu leio de novo, as que a gente leu. Eu não quero sair e já saber as estórias, entendeu? Não queria ler um conto que a gente ainda vai ler no círculo. Só reli. [...] Acho que em quantidade tô lendo igual.

Tiago: Não, só leio no círculo. [...] Não tô lendo mais não.

Penélope: Tô, tô lendo fora do círculo. O Guimarães Rosa eu deixo para ler no círculo porque eu gosto mais de ler os contos no círculo, mas os outros, a Odisséia, eu leio. [...] Livro tô lendo mais. Eu tomei mais gosto para ler livros, que antes eu não tinha. Eu lia, mas não com tanta freqüência.

Tal fato levou-nos a pensar se realmente o projeto está conseguindo efetivamente atingir o seu objetivo de "desenvolver o gosto e o interesse pela leitura", ou se "a ampliação do universo cultural-afetivo" é, por enquanto, o único objetivo que está sendo atingido. Há, evidentemente, uma grande importância em ampliar o universo desses jovens, porém, mais uma vez, a leitura está sendo usada como um instrumento para esta ampliação e não nos parece estar trabalhando efetivamente o desenvolvimento do gosto pela leitura, uma vez que os educandos não passaram a incorporar a leitura 
como atividade cotidiana ou como atividade prazerosa para ser realizada também nas horas de lazer.

Acreditamos que uma das causas principais do projeto não conseguir atingir o objetivo de formar leitores está na discussão realizada no item "7.2.1 Textos escolhidos". Exatamente pelo fato de a ONG não dialogar com o público que atende e ignorar os seus horizontes de expectativas, suas realidades de leitor movente e seus interesses. Este permanece sendo um grande desafio para o projeto. Há, sim, um despertar para a leitura e uma geração de interesse, mas não o suficiente para mobilizar os educandos em direção à busca de suas próprias leituras.

Em geral, também constatamos que os educandos que permanecem no projeto por mais tempo já gostavam de ler, mesmo antes de entrarem para os círculos. Em alguns poucos casos, obtivemos depoimentos de educandos que afirmaram que não gostavam de ler e aprenderam a extrair prazer da leitura após a participação no projeto, mas foram mais raros.

Laura: Eu não gostava MUUUITO assim, mas gostava, era vergonha mesmo, e eu perdi essa vergonha mesmo de ler, de tudo. Eu gosto de ler desde sempre, porque eu acho "mó" bonito ver as pessoas, as professoras lendo, assim, eu sempre achei bonito.

Taís: Eu sempre gostei de ler. Eu gosto de tudo o que me interessa, eu nunca tenho assim um objetivo, eu gosto só de drama, ou só de ficção, de tudo um pouco, depende. Não tenho um tipo favorito.

Cauê: Gosto, gosto. Nem sempre eu gostei. Comecei a gostar quando eu li "Harry Potter", faz uns 4 anos. Acho que na 6a série...

Tiago: Só gosto de ler o que me interessa. [...] Ah, eu leio, assim, só os livros que a escola passa... Eu não leio nada por conta própria.

Penélope: Eu comecei a gostar mais de ler assim, quando eu comecei a ler gibi, né? Aí comecei a ter o hábito e a ler sempre mais... Mas, eu sempre tive o hábito de ler.

Talvez, o fato de os educandos já terem a inclinação para a leitura explique suas participações voluntárias no projeto. Ou seja, não entram para os círculos aqueles que, 
por princípio, não gostam de ler. Quando surge alguém afirmando que não gostava de ler antes de entrar no projeto, em geral este participante vem depois de obter indicações de colegas. O maior desafio seria despertar o prazer da leitura naqueles que afirmam não gostar de ler, o que não está nos objetivos do projeto da ONG.

A própria pesquisa da ONG nos revela que os educandos que participam do projeto já possuem uma base que favorece a sua constituição como leitores: a maioria possui exemplo familiar de leitores, principalmente materno, assim como alguém que lia histórias para eles quando crianças. Estudos já comprovaram a importância da influência familiar na constituição do hábito de ler - em geral, aqueles que possuem exemplos de leitores em casa, acesso a livros e foram estimulados / habituados desde pequenos com narrativas, possuem maiores chances de virem a se tornar leitores freqüentes ou terem algum interesse pela leitura. Isso provavelmente não faz parte da experiência dos alunos que não mostraram interesse em participar do projeto ou que dele foram excluídos (Figuras 9, 10, 11 e 12).

Alguém lia histórias para você quando era pequeno?

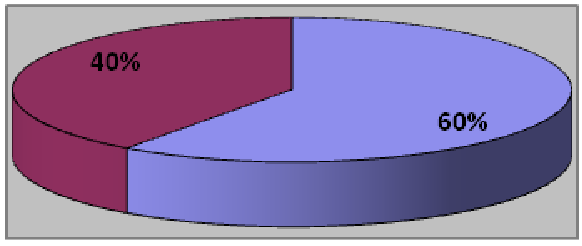


Além de você, quem tem o hábito de ler em casa?

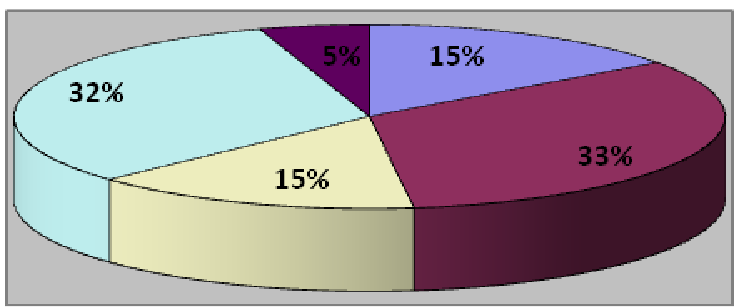

$\square$ Ninguém 口ที้อีลอ

$\square$ Pail

口|rmã̄os

Qutros

Fig. 10 - Dados resultantes do questionário inicial aplicado para 219 jovens no $1^{\circ}$ semestre de 2005

Alguém lia histórias para você quando era pequeno?

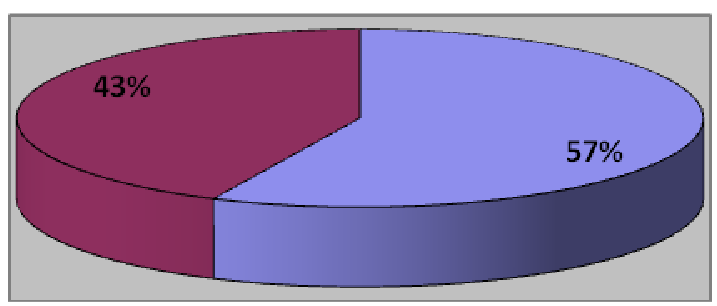

$\square \operatorname{sim}$

口Nลัก

Fig. 11 - Dados resultantes do questionário inicial aplicado para 123 jovens no $2^{\circ}$ semestre de 2005 
Além de você, quem tem o hábito de ler em casa?
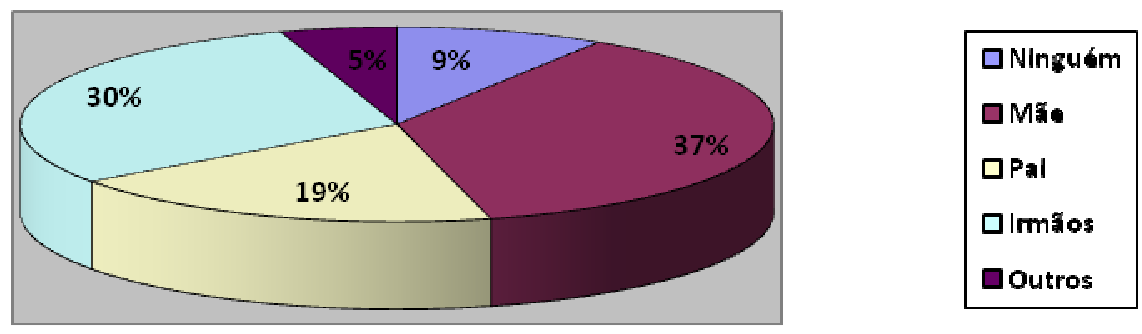

Fig. 12 - Dados resultantes do questionário inicial aplicado para 123 jovens no $2^{\circ}$ semestre de 2005

No entanto, para aqueles que participam do projeto, o trabalho da ONG é bastante importante ao estimular aqueles que já gostam de ler, ajudando-os a expandir seus horizontes. Acreditamos que isto reflete a visão (já contestada) da coordenadora Jurema, que afirmou que a ONG busca premiar os bons alunos e auxiliá-los a se desenvolverem. Muitos dos participantes do projeto, depois de conviverem com outros educandos, com as coordenadoras e com os vários convidados, passaram a almejar também cursar uma faculdade e dar continuidade aos estudos regulares.

Tivemos um exemplo disso em uma das visitas feitas à sede da ONG, quando conhecemos Letícia, 18 anos, participante dos círculos de leitura há três anos, que começara a freqüentar o grupo quando era aluna do $2^{\circ}$ ano do Ensino Médio de uma escola estadual de São Bernardo do Campo. Depois de ter entrado para o "Círculo de leitura", disse ter ficado tão entusiasmada com a literatura que agora cursa o $1^{\circ}$ ano de Letras na Faculdade Anhembi-Morumbi.

Conversamos também com Janaína, educadora contratada pela ONG 6 que, hoje, cursa Contabilidade. Ela começou a participar do círculo quando estava no $2^{\circ}$ ano do Ensino Médio, apesar de o projeto, em sua escola (em São Bernardo do Campo), só oferecer o círculo para as oitavas séries do Ensino Fundamental. Segundo ela, por ser 
muito curiosa e gostar de participar de diversas atividades, ao saber da existência do projeto, foi participar por conta própria, sem ter sido convidada.

Antes do círculo, Janaína afirmou que só lia os livros que a escola requisitava e não tinha o costume de ler por conta própria. Emocionada, contou-nos de seu primeiro círculo de leitura, ocasião em que, pela primeira vez, alguém lhe perguntou sobre o que ela gostava.

Em 2006, Janaína coordenou o seu primeiro círculo de leitura como educadora, na mesma escola em que estudou. Ela havia passado de aluna-participante para multiplicadora (estagiária) e, agora, era educadora contratada e auxiliava também na parte administrativa da organização. Ela afirmou, na época, estar muito ansiosa e emocionada por fazer este trabalho e poder contribuir para a melhoria de sua antiga escola, que sempre teve muitos problemas, inclusive a interrupção do projeto "Círculo de Leitura" por mais de um ano. Agora, feliz, ela deu início novamente ao projeto, com o auxílio e apoio da nova diretoria.

\subsubsection{AVALIAÇÃo DO PROJETO “CÍRCULO DE LEITURA" PELA PROFESSORA DE PORTUGUÊS E IMPACTO DO TRABALHO DA ONG NA ESCOLA}

Tomando por base a entrevista com Selma, professora de Língua Portuguesa dos alunos do grupo estudado, em São Bernardo do Campo, traçamos aqui a avaliação feita pela instituição escolar sobre o trabalho realizado pela ONG e sobre a parceria escolaONG.

Selma leciona há 15 anos para o Ensino Médio e Fundamental II e é parceira do projeto "Círculo de Leitura" há dois anos, tendo-o conhecido por intermédio da diretora da escola e também por ter participado de uma oficina promovida pela ONG na Diretoria de ensino de São Bernardo do Campo. Durante o ano de 2007, a professora Selma tinha cerca de 35 alunos no projeto. 
Quando questionada sobre o papel das ONGs na sociedade, Selma nos respondeu:

Mostrar à sociedade que é possível realizar projetos para melhoria sócio-cultural sem fins, somente, lucrativos; demonstrar que a organização de uma ONG bem centrada pode mobilizar toda sociedade para um bem comum e não se abater pelas críticas e - descrédito de alguns em relação aos objetivos e comprometimento social e cultural dessas ONGs.

Há no seu discurso uma conscientização do papel das ONGs, que ela acredita realizarem um trabalho sério e comprometido a favor da educação. Para Selma, a melhor forma de as ONGs ajudarem a escola pública é através de projetos que procurem envolver o jovem, "tornando-o protagonista de suas ações, tornando-o uma pessoa crítica com relação a si e ao mundo". Algo que ela acredita estar acontecendo na sua parceria com a ONG 6, que caracterizou como "muito produtiva e positiva", havendo um envolvimento recíproco entre ONG e escola.

No entanto, Selma chama a atenção para o cuidado que as ONGs devem ter para não caírem em descrédito, e defende que a proposta e objetivos das ONGs sejam muito bem explanados à comunidade. Para a professora, não existe possibilidade de as ONGs assumirem responsabilidades governamentais, pois não as enxerga "como uma 'bandeira' política, mas sim social'.

A parceria com o projeto tem sido extremamente positiva para a professora, pois os círculos têm acrescentado muito aos seus alunos, uma vez que ela mesma "não trabalha a leitura em sala de aula como gostaria”. Tanto os alunos como a própria professora admitiram que a leitura praticamente não é trabalhada em sala de aula, e leitura de literatura é inexistente. Segundo Selma: 
Trabalho com o Ensino Médio e, muitas vezes, os alunos são resistentes quanto à leitura, porém proporciono a eles leituras de jornais e revistas que levo diariamente para sala, deixando a leitura acontecer de uma forma livre, não imposta, e a partir daí, discutimos alguns assuntos ou temas. Confesso que a biblioteca é utilizada pelos alunos sem a minha participação. Oriento-os a utilizar a biblioteca, que na maioria das vezes é utilizada fora do horário de aula.

Assim, o círculo tem promovido aquilo que falta a suas aulas, é uma pena que ele só esteja sendo aproveitado por poucos alunos.

Para Selma, há uma "mudança significativa" no desempenho dos alunos que participam do projeto em relação à leitura:

$\mathrm{Na}$ maioria dos participantes é significativa a mudança, para melhor, porém há alunos que ainda se mostram tímidos e pouco à vontade para expor suas idéias ou criticar determinada situação fora do contexto do "círculo". Essa postura do aluno, muitas vezes, encobre a real evolução desse participante.

A professora afirma, ainda, que os alunos talvez se sintam mais à vontade para se expressarem dentro dos círculos do que na sala de aula, algo muito importante que discutiremos a seguir. 


\subsubsection{PROBLEMAS DE EVASÃO, DESEMPENHO ESCOLAR E OUTRAS CONSIDERAÇÕES}

Como afirmado no item 6.1.1.6 - Registro de presença e permanência na ONG, tem sido comum a evasão dos educandos do projeto. Este, por vezes, inicia-se com 60 educandos e termina o ano com 20.

Porém, segundo Jurema, os educandos que permanecem são freqüentes e dedicados ao projeto. A ONG dedica-se, portanto, aos que ficam, não dispensando atenção ou esforços àqueles que vão embora ou aos que não se interessam por leitura.

Deste ponto de vista, o sucesso do projeto parece facilitado, se apenas os acertos são focalizados e os fracassos não são objeto de reflexão.

Durante o período em que acompanhamos as atividades, observamos bastante seriedade e dedicação ao trabalho realizado, embora a ONG não busque trabalhar com desafios maiores, ou seja, com os alunos mais expostos ao fracasso escolar e aos reveses na vida pessoal e profissional. No grupo observado, houve a saída de apenas um membro, Tiago, que no início do mês de junho mudou de escola. Havia também a constante preocupação do educador em relação à frequiência dos educandos, metodicamente passando a lista de presença no início de todos os encontros, sempre notando se faltava alguém e perguntando por esta pessoa.

Há uma preocupação da ONG com o desenvolvimento geral daqueles educandos que permanecem no projeto. Além de trabalharem com o desenvolvimento da leitura, a ONG passou a ocupar-se de outras áreas educacionais. Tal fato originou-se da conclusão de que seus educandos possuíam um bom desempenho nas atividades de leitura e escrita, porém, quando eram requeridos outros conhecimentos, como o 
matemático, científico e organizacional, em geral, os educandos não se saíam muito bem.

Um dos parceiros financeiros da ONG havia solicitado aos coordenadores que indicassem seus melhores educandos a fim de prestarem uma prova que lhes daria direito a uma bolsa de estudo em um conceituado colégio particular de São Paulo. Para surpresa das coordenadoras, nenhum dos educandos obteve média suficiente.

Tendo em vista esta realidade, as coordenadoras concluíram que o desenvolvimento da leitura não era suficiente para que seus participantes fossem bons alunos. Foi comum observar que muitos dos educandos consideravam suficiente, como índice de sucesso escolar, seu bom desempenho em leitura, não se dedicando às outras matérias ensinadas na escola.

Assim, em 2005, a ONG iniciou o projeto “Academia de Ciências”, que tem sido um sonho do diretor do Instituto há muitos anos. Esta academia pretende ajudar os professores no ensino de Ciências, a partir de um intercâmbio com centros de excelência na área. Assim, a ONG colocou um professor e dois ajudantes em uma escola pública, para fazer alguns projetos pilotos tendo em vista ajudar a criar estratégias identificadas com o ensino de Ciências. Desta maneira, deram início a outros projetos na área educacional.

Há, portanto, uma focalização nos alunos que já se interessam pela leitura, enquanto se ignoram os alunos dissidentes. Assim, é fácil afirmar que o projeto é um sucesso. Seria necessário fazer um levantamento dos educandos que desistiram das atividades da ONG para que ficassem mais claros os motivos das desistências e o que pode ser feito para que o projeto seja melhorado, mantendo todos os educandos que iniciam as atividades. Se apenas os acertos forem focalizados, não há como corrigir os erros, não há como melhorar e, sobretudo, não há como expandir o projeto para toda a escola, intensificando o processo de constituição de leitores.

Infelizmente, não houve tempo hábil, neste trabalho, para pesquisarmos as causas da evasão, mas futuros pesquisadores e, principalmente, a própria ONG poderia se encarregar desta tarefa e buscar pontos que podem ser melhorados, como, por 
exemplo, os critérios para a escolha do material de leitura que, segundo nossa hipótese, constitui-se como principal determinante para o fracasso do projeto em ampliar o número de leitores.

\subsubsection{RELACIONAMENTOS INTER-PESSOAIS: A QUESTÃO AFETIVA E GRUPAL}

Com base nas entrevistas, conversas e observações, o principal fato que nos chamou a atenção dentro da pesquisa de campo foi o envolvimento dos educandos e as relações estabelecidas entre eles.

Ao perguntar para os educandos o que, dentro do círculo de leitura, era o mais importante e a razão principal para gostarem das atividades propostas, a grande maioria, para a nossa surpresa, não respondeu ser a leitura o ponto fundamental, mas sim a convivência em grupo e o fato de, nele, terem espaço para se expressarem e serem respeitados. Com o passar do tempo, foi se tornando clara a necessidade que os educandos possuíam de serem ouvidos e terem suas opiniões consideradas. Dentro do grupo e pela leitura, muitos ganhavam voz pela primeira vez e aprendiam a se expressar oralmente, ordenando seu pensamento.

\section{Entrevista - [12-04-2007]}

Renato: Acho que o que mais gostava nos círculos quando era participante e não educador é o interesse pelo que você tem a dizer. Porque eu acho que antes o que eu tinha para dizer era muito combativo. Então, eu vinha já com pedras nas mãos para falar com as pessoas, porque eu sabia que eu tinha que romper uma crosta difícil, e às vezes eu tava falando em um lugar errado. Eu descobri que tinha um lugar para falar, para pensar, para aceitar, para ESCUTAR também. Eu não tinha esta relação de falar e também ouvir. Porque eu ouvia sempre em combate, sempre chocando as idéias, e então eu descobri que eu podia falar uma coisa sem entrar em conflito, eu podia discordar de alguém e alguém podia discordar de mim e a gente não resolver o paradoxo, e o paradoxo que era bom mesmo. Mas acho que quebrou um vício de tentar também, é abstrair uma idéia da literatura e isso virar um conceito, e você necessariamente colocar naquela relação tensa de que uma idéia tem que vencer a outra, porque há uma verdade. Sendo que a literatura justamente é a possibilidade de quebrar com conceitos, de você dizer coisas de um modo completamente contraditório e por isso conseguir dizer mais. Aí, quando eu fui colocado nessa situação, eu acho que foi 
uma das coisas mais interessantes. E também não era como eu pensei uma aula de literatura.

Pesquisadora: Em relação aos seus educandos, qual você acha que é a motivação principal daqueles que permanecem no projeto?

Renato: Eu acho que é porque eles sentem que a inteligência deles é valorizada, eles se descobrem inteligentes e talentosos, eles não sabiam disso. E um outro motivo, que eu acho, é quando eles descobrem também que a arte é transcendente. Eles se empolgam muito com isso, porque realmente é descobrir um nível de realidade outra. Então, eu acho que isso sustenta. Mas, em um primeiro momento, acho que primeiro é porque eles gostam de falar, de dar a opinião deles, acho que pela mesma razão que eu fiquei. Junta o encantamento, eles se sentem inteligentes, às vezes, nem sabem que são, mas eles sentem. E também porque eles criam vínculos com pessoas, num nível que eles não conseguem criar em outras condições. Como, por exemplo, a gente foi para o Rio de Janeiro e um menino falou que viajou inclusive com pessoas, às vezes da família ou de outros projetos, e ele não conseguiu ter um envolvimento com elas como ele teve através do círculo de leitura. Então, a gente lia, e as próprias atividades que a gente fazia, mesmo se divertindo tinha outro significado.

Outros depoimentos:

Laura: É... é difícil falar uma coisa só que eu goste no círculo... talvez, sei lá... o convívio com a leitura, sei lá, eu não sei, muitas coisas mesmo. Sei lá, a gente consegue viajar e é opiniões diferentes, saber respeitar opiniões dos outros, e eles também respeitam a minha opinião, então é uma coisa que, não tem aquela opinião... o professor [educador] Renato, fala uma coisa, a gente dá opinião e talvez não é a mesma dele, mas no círculo ele aceita, sei lá viajando junto com a nossa opinião. O Renato viaja na nossa opinião, e é super legal, porque a gente não fica só com a opinião dele, né?

Na aula, tem alguns professores que não aceitam a nossa opinião, quer dizer aceitam, mas não tanto quanto aqui. Aqui a gente desenvolve mais, e vai mais além.

Tiago: Um motivo principale Acho que é a discussão que tem, né? Para saber melhor as coisas. Tanto é que quando eu leio, na hora que a gente tá lendo lá, eu não consigo ver o que as outras pessoas estão vendo. Daí depois com a discussão, eu vou entendendo melhor.

Penélope: $O$ que eu gosto do círculo é o debate de opiniões. E poder ver outra interpretação daquele texto ali. 
Este convívio em grupo, a sensação de pertencimento e respeito que observamos em todos os grupos parece-nos fundamental para o sucesso do projeto dentre aqueles que nele permanecem. Há uma preocupação clara com a auto-estima dos participantes, desde a escolha dos textos até a condução dos grupos. Cremos que este enfoque deve-se, sobretudo, à visão terapêutica da idealizadora do projeto, ela mesma analista.

Na primeira visita, após a conclusão das atividades do círculo de leitura do qual participamos, junto da idealizadora do projeto, Carina, fizemos os seguintes comentários:

Durante este círculo que presenciamos e do qual também participamos (pois Carina nos invocou a opinar sobre o que líamos, a fim de conhecer-nos e de decidir se nós possuíamos ou não o perfil do projeto para que nos permitisse pesquisá-lo), observamos que, como educadora, filósofa, psicanalista e mediadora de leitura, Carina possuía uma preocupação bastante grande em deixar todos à vontade, além de se preocupar em dar voz a todos os participantes, chamando os mais tímidos a também se expressarem. A opinião de todos foi considerada, discutida e respeitada, não criando em nenhum momento embaraço, humilhação ou bloqueios em relação à própria leitura ou à participação dentro do grupo. Carina elogiou as boas idéias, aumentando a segurança daqueles que se expressavam.

[...]

É bastante evidente a sua preocupação com o desenvolvimento afetivo dos participantes, além de fornecer segurança para que eles possam assumir sua individualidade, suas opiniões e expressar sua sensibilidade.

Ficamos bastante surpresas com a desenvoltura e a forma com que todos os educandos se expressaram. Naturalmente, os educandos que lá se encontravam já são os de melhor desempenho dentro de cada grupo nas escolas, porém, ficamos satisfeitas em observar o entusiasmo com que falavam, a paixão demonstrada por alguns pela discussão e a segurança e conforto com que se expunham. 
Este apelo afetivo do grupo, marcante no projeto, muitas vezes acaba sendo o principal motivo para a participação e permanência dos educandos. Tendo como principal objetivo o desenvolvimento do gosto e do interesse pela leitura, o projeto acabou atingindo um objetivo diverso, por meio da leitura: o desenvolvimento da identidade e da auto-estima.

Observamos que os educandos realmente necessitam deste cuidado com a autoestima, uma vez que a maioria se mostra insegura quanto à prática da leitura. Como vimos anteriormente, praticamente nenhum dos entrevistados respondeu que se considerava um bom leitor. Houve também um episódio bastante interessante no grupo pesquisado, que refletiu o conceito que os educandos possuíam de si mesmos e de seus colegas, conforme anotamos no diário:

Os alunos entraram na biblioteca querendo saber o significado da palavra DEFERIDO e, instigados pelo educador, levantaram hipóteses partindo do que estava escrito quando aparecia e quando não aparecia a palavra "deferido". Eles tinham visto esta palavra seguindo uma lista de nomes no mural da administração da escola. Em alguns nomes estava escrito "deferido" e, em outros, "falar com a diretora". Os alunos chegaram à conclusão de que deveria ser algo ruim, pois a maior parte dos nomes estava com "deferido" ao lado. Um dos educandos, em tom de brincadeira, afirmou que os alunos da escola não eram muito bons - revelando uma auto-imagem depreciativa, como parte do corpo discente. Ao ouvir isto, Renato afirmou que ele estava sendo injusto, e ele concordou. Renato aproveitou para ressaltar como o juízo deles sobre si mesmos estava errado. Pois se no lugar de "deferido" estava "falar com a diretora”, aí sim queria dizer que havia algum problema. Um dos alunos completou: "Não sei o que passou na cabeça da diretora para pôr uma palavra que ninguém entende”.

Foi interessante notar, ao longo das observações, o estímulo do educador durante os encontros e os mecanismos que ele usou para que os alunos tivessem sempre a sua inteligência respeitada. Além de estimular os educandos, tecendo elogios, considerando suas complementações e ficando verdadeiramente entusiasmado com o que os 
educandos falavam, há um momento em que Renato usa a expressão "a gente", grifada no texto abaixo, deixando claro que o raciocínio feito e as interpretações às quais o grupo chega são fruto de todos e não dele ou de um só educando, ajudando a criar um sentimento de unidade e cooperação. É um momento em que todos se sentem valorizados, respeitados e podem expor suas opiniões.

\section{[12-04-07] - Leitura do conto "Seqüência"}

Taís: "Esse seu Rigério tinha os filhos diversos..." - [Ela pára para rir, acha o nome engraçado]

Cauê: É, Rigério, de rígido...

Renato: Cauê, eu sempre gosto dessas associações, guarda isso vamos pensar nessa idéia depois.

$[\ldots]$

[Depois do sétimo parágrafo]

Renato: Tá dando para acompanhar a estória? O que está acontecendo?

Carla: A vaca tinha fugido, aí o filho do Seu Rigério, um deles se interessou e foi atrás.

Renato: Exatamente, o único. Ele não precisava ter ido. Tinha muitos filhos lá, esse fazendeiro podia pôr alguém atrás desta vaca. Mas, este filho ainda perguntou: "É uma vaquinha pitanga?"

Taís: Eu grifei...

Renato: Por que você grifou? O que você pensou?

Taís: Porque aqui no começo, a vaquinha é vermelha...

Renato: Exatamente. E ela sai, é dito aqui, numa madrugada "num céu quase da sua cor". É muito interessante isso. Primeiro ela é uma vaca vermelha, mas ela sai para esta viagem dela, quando o céu está meio avermelhado. O que vocês pensam com isso?

Penélope: $\mathrm{O}$ céu está nascendo...

Renato: Exatamente. Mas o que que isso pode significar simbolicamente?

Cauê: Camuflada. 
Renato: Camuflada, meio confundida. Mas assim, ela está camuflada no mundo, não tá? Ela tá meio que confundida com o mundo? Parece que a essa altura, aquela manhã, aquele céu não se distingue muito da vaca. E é engraçado isso, não é? Ela está camuflada, mas no mundo. Em sintonia com esse céu. $O$ céu e a vaca têm tudo a ver. Tem ou não tem? Tem tudo a ver, é a hora inclusive que ela escolhe para sair, fugir. Assim, essa vaca não é qualquer vaca não, vocês não acham?

Cauê: Eu achei interessante, nesta parte que ele pergunta "mas, é uma vaquinha pitanga?" Tipo ele sabia alguma coisa, tinha algum interesse nela.

Renato: É, eu acho que é por isso, olha que interessante o que A GENTE está conseguindo propor. Olha só, a vaca é vermelha, ela sai com um céu quase da sua cor, você fala que ela tá camuflada, ela tá camuflada nesse mundo então. Está explicitamente esta relação, o céu e a vaca tem alguma coisa aí que a gente ainda não sabe o que que é. E esse rapaz sabe alguma coisa que esta vaca tem, porque ele vai, ele confirma se é uma vaca vermelha para ele ir atrás dela.

$[\ldots]$

Renato: E aqui fala: "o inimigo já vinha perto", mas tem alguma coisa aqui... "um salto que queria ser vôo..."

Taís: O desenho...olha o desenho da seqüência...

Renato: O que que tem o desenho?

Taís: Tem um cara aqui com muito cara de mau, aí tem o moço lá com o cavalo indo atrás da vaquinha. Nesse lugar tem uma estrela...

Renato: $\underline{\text { Perfeito. }}$

Taís: Muito bem destacada...

Cauê: Quase maior do que a casa...

Taís: E essa flecha saindo de lá e está indo...

Renato: Puxa, olha é mesmo uma flecha bem...

Taís: Que desvia da vaca...

Renato: É verdade, ela passa por baixo da estrela, por cima da vaca, em direção a esse rapaz no cavalo...

Taís: Então, eles estão saindo do mal, porque olha a cara de medo...

Renato: Fala, fala, eu tô adorando...

Taís: Olha a cara de bravo... 
Renato: Saindo do mal... Ótimo! Fala, fala!!! [todos riem da empolgação do educador] Isso saindo do mal e o que mais?

Taís: Estão indo assim: "eu vou indo para a minha sina, a minha estrela, a minha luz", tem a estrela aqui.

Renato: Perfeito. Parece que este rapaz está buscando um destino, você fala procurar a minha sina, não é? Parece que essa vaca, intuitivamente, a gente sabe que essa vaca tem um destino. "É a vaca pitanga?", então é hora de eu me pôr na estrada a caminho porque chegou a hora. Parece que tem isso aqui.

Cauê: Parece que ele sabia que ele ia se dar bem, ou coisa assim...

Renato: É, e essas estórias dessas pessoas que se põem a caminho, sempre são desviadas, você está andando aí de repente você segue um animal... aí sua vida muda... não sei. Os heróis têm umas coisas assim, não têm?

Cauê: Têm.

Renato: Então, acho que não está à toa não. Vamos guardar isso aqui que a Taís falou. Vocês prestaram atenção no que a Taís falou? Vamos guardar isso. Acho isso fundamental, eu acho que é por aí mesmo.

$[\ldots]$

[Após $12^{\circ}$ parágrafo]

Renato: Interessante isso...

Natália: Ele tá falando em setembro, mas não era outubro?

Renato: É, perfeito, perfeito o que você está falando... Ele fala junho, outubro, não sei... ele fala de agosto, agora fala de setembro... são fases, é engraçado, se você pegar ao pé da letra foi em um dia isso, né?

Natália: É, mas para ele não.

Renato: Mas, ao mesmo tempo, é por isso que eu estou falando, ele não tá falando só de uma estória... MUITO bem sacado isso, Natália. Ele não está falando de uma estória de um cara que vai atrás de uma vaca simplesmente, ele tá falando de um movimento, de

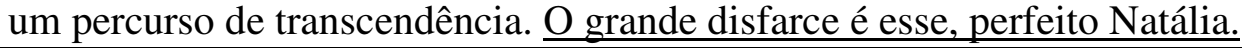

Aparece também no documento do projeto a preocupação com este convívio em grupo:

(...) acreditamos que o espaço do grupo é a liberdade do devaneio. (...) Neste espaço se rompem as barreiras que separam 
um eu do outro, desaparecem as hierarquias, e isso cria um estado de bem estar que libera a imaginação, e os sentimentos mais variados estão em liberdade de entrar em novas combinatórias. (...) $\bigcirc$ que sustenta o trabalho dos Círculos de leitura é oferecer a possibilidade de promover essas formações grupais do psiquismo humano, que se manifestam quando lemos nos deixando conduzir pelo fluxo das idéias, das palavras, que um determinado texto promove.

Assim, talvez o principal mérito de todo o projeto seja mesmo o incremento da auto-estima dos educandos, deixando a leitura em segundo plano. $\mathrm{O}$ desenvolvimento da leitura parece ser, na verdade, um mecanismo e não um fim em si mesmo, como já havíamos notado. Desta forma, a preocupação com a leitura e com o desenvolvimento do prazer estético perpassa o projeto, não sendo seu principal foco. A leitura é vista, então, como um dispositivo para "ampliar o universo cultural-afetivo" dos participantes, o que o projeto tem conseguido fazer com relativo sucesso. 


\section{CONSIDERAÇÕES FINAIS}

O problema que motivou esta pesquisa originou-se da constatação do baixo grau de letramento dos jovens brasileiros e, portanto, do fracasso do ensino público em constituir leitores. Na expectativa de encontrar soluções para esta questão, voltamos-nos para a sociedade civil em busca de respostas e novas propostas. Fizemo-nos, então, a seguinte pergunta:

A sociedade, por meio das organizações não-governamentais, pode efetivamente ajudar a melhorar o quadro do baixo grau de letramento dos alunos brasileiros? E, se possível, como e em que medida?

Diante da problemática, dispusemo-nos a pesquisar o tema a partir de um estudo de campo em uma ONG que, observando a falta de investimento do governo nos projetos de constituição de leitores, acreditou na possibilidade de reversão do quadro apresentado pelo exame do PISA 2000 e 2003. Como pudemos verificar, é uma tentativa de mudança pontual e modesta se pensarmos no sistema educacional como um todo no Brasil, mas ela apresenta elementos que podem contribuir para uma transformação.

A análise dessas ações pontuais é importante, pois ao prestar atenção ao micro, àquilo que está latente na sociedade, podemos perceber as pequenas transformações que vão influenciar o campo político, mudando, posteriormente, também os códigos sociais, a visão de mundo e as atitudes cotidianas. Habermas (1984) já dizia que um sistema particular possui a capacidade de ressonar no público.

A nova mentalidade, a visão de mundo e as práticas apresentadas por estas ações sociais são respostas a problemas existentes há muito tempo na sociedade complexa, são respostas aos anseios do povo que o Estado/sistema se recusa a fornecer.

Assim, nesta pesquisa de cunho etnográfico, baseada em observações feitas em campo, entrevistas e análise de documentos, partimos de um referencial teórico que 
buscou discutir a importância de se considerar leitura como prática social e o papel do desvelo e do prazer emocional na constituição do leitor, a fim de que se consiga atingir o grau crítico necessário para desfrutar do prazer estético que uma obra pode oferecer. Para tanto, fizemos uso de concepções provenientes da Psicolingüística e da Estética da Recepção.

Desta forma, tendo em vista as fundamentações teóricas apresentadas nos capítulos 2 e 3, trabalhamos com a concepção de leitura como produção, recepção e comunicação (poiesis, aisthesis, katharsis). Isto levou-nos a refletir sobre a importância da Estética da Recepção no auxílio aos educadores quando da escolha do material de leitura a ser trabalhado, bem como na orientação sobre a maneira de abordar-se a leitura. Compreender a dinâmica da recepção e os elementos afetivos e cognitivos que ela envolve é fundamental para entendermos quem são os sujeitos que queremos "transformar" em leitores, quais são seus universos de expectativas e com o que eles se identificam.

Assim, o primeiro passo nos pareceu ser a sedução dos sujeitos para a leitura a partir do prazer e do afeto, para, em seguida, buscar neles a participação experimentadora. A questão a ser resolvida torna-se, então, a passagem da contemplação desinteressada para a participação experimentadora que envolve a reflexão estética que cabe ao professor desenvolver nos seus alunos. Dessa forma, o trabalho do professor deverá permitir que seus alunos possam vir a julgar e fruir a leitura e, assim, recriar a obra de arte, como afirmou Goethe (Jauss, 2002, p. 103).

A idéia fundamental que surge dos estudos de leitura, com o foco no leitor, talvez seja a questão do prazer estético e, antes dele, do prazer emocional cuja importância é bastante elevada, na medida em que dele depende a sedução para a leitura. Assim, haverá também maior probabilidade de êxito para o desenvolvimento de habilidades fundamentais de leitura, a fim de que o aluno possa, finalmente, tornar-se um leitor competente e crítico, usufruindo o prazer e a experiência estética em todas as suas dimensões.

Dentro do contexto da leitura como prática social viva, dentro de um diálogo que nunca termina, podemos pensar na literatura como "comunicação inter-humana", da 
maneira proposta por Bakhtin. Tendo isto em vista, os círculos de leitura propostos pela ONG 6, espaço para se ler sem preocupação com o tempo e, principalmente, espaço para dialogar e dar voz aos jovens, possam desvelar um caminho que facilite a construção do conhecimento, a fruição do prazer estético e a constituição de um horizonte de expectativas. E quem sabe, então, o professor ou o educador como mediador de leitura possa direcionar e guiar os jovens neste caminho, transformando a leitura efetivamente em uma prática social mais construtiva e humanizadora.

Aproveitamos também para fazer um percurso pelas ações sociais de algumas ONGs e seu papel na transformação da sociedade pós-moderna. A ação voluntária da sociedade civil permite sua autonomia e possibilita, também, pressionar as autoridades públicas, anunciando mudanças possíveis. São estas ações que preparam modelos que serão utilizados por instituições, colaborando para o fortalecimento da democracia e trazendo a esperança de que um outro mundo é possível, pois existem respostas. Para Melluci (2001, p. 121):

\begin{abstract}
Existe na ação voluntária, uma função de mudança que me parece necessário distinguir em dois aspectos. O primeiro é o da inovação. A ação voluntária é o laboratório no qual são preparados os modelos culturais, organizativos, relacionais que podem ser transferidos ao mercado ou às instituições. Aqui opera também o recrutamento das elites que já falei. O segundo, ao contrário, refere-se a uma função profética. A ação voluntária, por sua própria presença, revela e anuncia: revela a existência escondida de grandes dilemas que atravessam as sociedades complexas e anuncia que "algo novo" é possível. (...) E, assim fazendo, desafia o sonho da potência e convida para a mudança e para a responsabilidade. Exatamente porque gera, revela, tira do silêncio, a ação voluntária, quando não responde a necessidade de tranqüilização, ou como função de protesto social, é um componente vital do processo de renovação de uma "sociedade civil" digna deste nome: civitas pública e individual ao mesmo tempo, capaz de colocar a diferença e de reforçar a solidariedade.
\end{abstract}

No presente trabalho, procuramos ressaltar a importância da ação social da ONG 6 para fazer com que a ampliação do grau de letramento por meio da leitura prazerosa seja um instrumento de inserção social e de socialização do conhecimento. Dessa forma, favorece-se a formação de verdadeiros atores sociais que não se submetam a mecanismos simbólicos de perpetuação de desigualdades, como já alertara Marx (2002). 
Após traçarmos um panorama das atividades educacionais promovidas por diferentes ONGs na cidade de São Paulo, com o intuito de montar um panorama das práticas pedagógicas destas instituições e sua forma de funcionamento, partimos para a análise das atividades da ONG 6. No decorrer da investigação, pudemos conviver semanalmente com os sujeitos da pesquisa por um longo período, para entendermos melhor a dinâmica nas relações entre os participantes, a proposta e o funcionamento do projeto "Círculo de leituras", bem como as concepções de leitura e leitor dos sujeitos envolvidos neste estudo.

Buscamos descrever o processo metodológico que envolve o projeto e os seus resultados, verificados ao longo da pesquisa. Constatamos a preferência da organização em focalizar os acertos e em optar por escolher os melhores educandos de cada grupo para estimular e desenvolver suas capacidades. É um mecanismo de auto-sustentação do projeto, na medida em que continuam formando multiplicadores e educadores e, assim, vão expandindo as atividades para outras escolas. No entanto, fica aqui, novamente, a questão: e aqueles educandos que nunca tiveram prazer em ler? Aqueles já marginalizados pelo sistema escolar que não vão espontaneamente participar dos círculos? Há efetivamente constituição de novos leitores neste projeto? Ou se desenvolve a capacidade daqueles que, de alguma forma, já estabeleceram um relacionamento prévio (antes da participação no projeto) com a leitura?

Há inúmeras histórias positivas na ONG pesquisada, sucesso, sobretudo, no que se refere à construção da auto-estima dos educandos e ampliação do seu "universo cultural-afetivo", mas nem sempre na constituição de leitores. Por enquanto, não foi possível perceber um incremento significativo na freqüência de leitura dos educandos:

Pesquisadora: Você lê fora do círculo?

Natália: Não, não muito. Antes eu lia mais... Porque agora eu tenho a escola, depois eu tenho o treino, depois eu tenho trabalho, eu não tenho tempo. Aí à noite, eu tomo banho e vou dormir, praticamente. Aí eu não perco meu tempo, o pouco tempo de sono. Eu não tenho tempo.

Carla: Não, porque é falta de tempo. Chego do curso, jogo as coisas e vou arrumar a casa para a minha mãe... eu gosto mais de ler os contos no círculo, mas os outros, a Odisséia, eu leio. 
Pesquisadora: Você está lendo mais com o círculo?

Natália: Não. Não leio fora do círculo, só revistas.

No entanto, há, em muitos educandos, evidências de melhora no desempenho tanto no que se refere à capacidade de interpretar um texto, de concentrar-se na leitura, bem como na organização do seu pensamento e, algumas vezes, no desenvolvimento do prazer estético. Como podemos perceber na fala dos educandos Carla, Natália e Cauê:

Pesquisadora: Você já sente alguma diferença na sua forma de ler, depois de participar do projeto?

Carla: Mudou um pouquinho. Agora eu já dou uma interpretada, interpreto mais, mais e mais. E vou vendo, porque uma coisa liga à outra, e eu vou vendo as possibilidades, o que acontece, assim... Antes eu até tentava fazer alguma relação, mas não conseguia, agora sim.

Natália: Sinto, sinto. Eu acho que eu leio com mais calma, com mais atenção para depois eu poder falar alguma coisa. Para não ficar boiando no que tão falando. Você lê com mais atenção.

Cauê: (...) Então, o que eu falei de interpretação, consegue ficar bem mais fácil, você aprende aqui a interpretar (...) depois do "Círculo" você começa a prestar mais atenção nos mínimos detalhes que nem dava bola (...)

De modo geral, o projeto "Círculo de Leitura" tem obtido bons resultados e é visto com bastante credibilidade pelas diretorias das escolas estaduais em que atua. $\mathrm{O}$ projeto iniciou-se no município de São Bernardo do Campo atuando em centros de juventudes do governo municipal e estadual, e não nas escolas. Com o passar do tempo foi ganhando mais visibilidade e a própria Secretaria da Educação Municipal procurou a ONG para que esta levasse seu projeto às escolas.

A maior parte dos círculos de leitura acontece fora do horário de aula, porém, no ano de 2007, algumas escolas, a pedido da própria direção, requisitaram que as atividades da ONG ocorressem durante o período de aula, fazendo parte da grade escolar, o que representou um enorme avanço em termos de influência da sociedade civil nas políticas públicas de educação do município em questão. 
O objetivo atingido pela ONG e pelo projeto "Círculo de Leitura" tem sido, sobretudo, a ampliação do universo cultural dos alunos, colaborando para que os melhores alunos das escolas públicas do $\mathrm{ABC}$ paulista continuem seus estudos no Ensino Superior e, na melhor das hipóteses, em universidades públicas.

Talvez o que favoreça o sucesso dos "laboratórios pedagógicos" das mais diversas ONGs seja a vantagem que possuem em relação à escola, pelo fato de os educadores não se sentirem obrigados a cumprirem um currículo pré-determinado e não sofrerem as inúmeras pressões e cobranças que os professores sofrem por parte de alunos, pais, diretoria e do próprio tempo. Além disso, ainda trabalham com alunos que participam espontaneamente das atividades, o que resulta em maior interesse e entusiasmo.

Concluímos que, na perspectiva do que foi observado, o projeto "Círculo de Leitura" da ONG 6 não atingiu os objetivos almejados, a saber, "desenvolver o gosto e o interesse pela leitura", uma vez que, geralmente, trabalha com jovens que já se interessam pela leitura e não precisam desenvolver o gosto. Ao destacarem o sucesso do projeto, seus idealizadores estão, na verdade, camuflando o fracasso expresso pelas faltas e problemas de evasão. Desta forma, eximem-se de buscar melhorias, traçando, de certa forma, um panorama enganoso do projeto. Quando optam por trabalhar apenas com jovens que se interessam pela leitura, não colaboram com a formação de novos leitores.

Por outro lado, entre os educandos que não são excluídos e que participam do projeto, há muitos ganhos cognitivos, como pudemos observar por meio das entrevistas. A maioria afirma ter melhorado seu vocabulário, adquirido fluência na leitura em voz alta e desenvoltura na expressão oral. Também observaram incremento da concentração, da reflexão e da capacidade de interpretar texto. Todos estes ganhos são importantíssimos para estes alunos e certamente melhoraram o seu grau de letramento transformando a leitura, de mera decodificação de um texto, em diálogo e aprendizado, o que contribuiu para torná-los mais críticos e aptos a dialogar com a sociedade, instaurando-se como sujeitos. 
Assim, nossas hipóteses só se confirmaram em parte, uma vez que a ONG 6 ajudou a melhorar o grau de letramento dos alunos da escola pública, no entanto, só de alguns poucos e daqueles que já possuíam propensão à leitura, tendo, raríssimas vezes, ajudado efetivamente a constituir novos leitores. Ao menos de imediato, não foi observada a formação do gosto pela leitura e o hábito da mesma pelos educandos participantes. Ou seja, o projeto "Círculo de leitura" ajuda a melhorar o grau de letramento (dos alunos não excluídos do projeto), mas não tem constituído leitores.

No entanto, ao procurar descobrir se a ONG 6 conseguia de fato despertar o prazer da leitura, outro resultado emergiu. Com o intuito de verificar como se estabeleciam as relações entre os jovens e a leitura, constatamos, por outro lado, a importância do estabelecimento de relações entre os próprios jovens e o fortalecimento de sua auto-estima, tanto consigo mesmos como em relação à leitura.

Os vínculos afetivos e a sociabilidade juvenil têm um papel central no sucesso do projeto entre os seus participantes. A construção da identidade, o estabelecimento de relações inter-pessoais saudáveis, a liberdade de expressão, o direito à escuta e consideração foram elementos decisivos e importantes para o desenvolvimento do letramento destes jovens e a melhoria do seu desempenho escolar. O trabalho com a auto-estima e com a ampliação do "universo cultural-afetivo" proposto pela organização foi um sucesso. Assim, apesar de não intensificar o gosto e o interesse pela leitura, a ONG 6 conseguiu, no entanto, tornar os seus educandos mais confiantes em si mesmos, uma vez que se consideram mais inteligentes depois da participação no projeto e possuem agora mais recursos e conhecimento para a vida.

A ONG 6 e o projeto "Círculo de Leitura" nos ensinaram a importância da focalização e do trabalho com a auto-estima dos alunos do sistema público de ensino, que, muitas vezes, consideram-se menos capazes do que são, como vimos no corpo da nossa análise. O fortalecimento da auto-imagem e da sociabilidade em um ambiente seguro, no qual sua inteligência é valorizada, favorece a melhoria do letramento, mas também de qualquer atividade cognitiva. O que seria necessário é a ampliação do trabalho da ONG 6 para todos os alunos, sem exceção. 
Para que o projeto fosse realmente bem sucedido na constituição de novos leitores, propomos o que consideramos fundamental: que a ONG se abrisse para um diálogo inicial e verdadeiro com os jovens, procurando entendê-los em suas realidades (de leitores moventes) e em suas fontes de interesse. Isto ajudaria a melhorar as escolhas de leituras e a atrair mais alunos. Seria também importante que seus educadores possuíssem uma base mais sólida em questões educacionais e literárias, além de buscarem, ainda, focalizar um pouco mais a escrita e re-escrita dos textos dos alunos, como forma não só de retomar a leitura, mas também de aprender a organizar o próprio pensamento. O trabalho com outras linguagens, como a música, pintura ou cinema, também deveria marcar presença, assim como os momentos de leitura individual, para estimular preferências e formar leitores autônomos.

De acordo com a professora Selma, representante da escola pública, o projeto da ONG 6 trouxe muitos benefícios para os seus alunos, colaborando inclusive para a melhoria do grau de letramento dos alunos e de seu desempenho em sala de aula. Tendo em vista as afirmações de Selma, podemos considerar que a escola pública tem, sim, a ganhar com o estabelecimento de parcerias com ONGs que podem, no caso de Selma, ajudar a professora, na medida em que desenvolvem atividades que ela mesma não tem tempo, nem espaço no seu currículo para realizar.

Assim, a sociedade, por meio das ONGs, pode sim ajudar a escola a melhorar de diferentes formas, inclusive tornando-a mais aberta à sociedade. Segundo a revista Nova Escola (Ano XXII, no 203, junho/julho 2007, p. 55):

Hoje as ONGs são um aliado na melhoria do ensino: formam professores, trazem idéias de gestão, oferecem atividades no contraturno e mobilizam professores e alunos em projetos que vinculam a escola ao mundo externo.

Na pesquisa realizada por nós, concluímos que, apesar de algumas falhas, a ONG colaborou para a melhoria do grau de letramento dos alunos participantes do projeto, mas foi excludente e não constituiu novos leitores. Mesmo assim, sua colaboração foi efetiva e importante para a escola. 
Desta forma, a colaboração decorrente destas iniciativas, que nunca devem ser excludentes, como ainda ocorre, pode ter grande valor para a melhoria da escola pública. Dialogando e levando até ela alternativas que possam ser vivenciadas no ambiente escolar, lançando um novo olhar sobre a escola, criando espaços de troca e mobilizando a sociedade, as ONGs podem dar mais um passo na melhoria do ensino como todo, e quem sabe, um dia, na constituição de novos leitores. 
AGUIAR, F. (org.). Antonio Candido: pensamento e militância. São Paulo: Editora Fundação Perseu Abramo, 1998.

ALVES, R. Aprendiz de mim - um bairro que virou escola. Campinas: Papirus, 2004.

ANDRÉ, M.; LÜDKE, M. Pesquisa em educação: abordagens qualitativas. São Paulo: Editora Pedagógica e Universitária, 1986.

AOYAMA, A.L. F. O papel do terceiro setor em ações de educação não-formal a partir da década de 1990 no Brasil. São Paulo: Dissertação de Mestrado, FEUSP, 2005.

ARENDT, H. "A crise na cultura: sua importância social e política” In Entre o passado e o futuro. São Paulo: Perspectiva, 2000.

ARISTÓTELES. Poética. São Paulo: Ars Poética, 1993.

AZEVEDO, M. A. Alfabetização hoje. São Paulo: Editora Cortez, 1997.

BAKHTIN, M. Questões de literatura e de estética - A teoria do romance. São Paulo: UNESP/Editora Hucitec, 1988.

BECKER, H. Problems of inference and proof in participant observation. American Sociological Review, 23, 1958.

BRUNSTEIN, J. ONGs e educação: novas possibilidades educativas? São Paulo: Tese de Doutorado, FEUSP, 2003. 
BOGDAN, R. e BILKEN, S.K. Qualitative Research for Education. Boston, Allyn and bacon, Inc, 1982.

BRASÍLIA. Orientações Curriculares Nacionais para o Ensino Médio. O conhecimento da literatura. Brasília: SEB-MEC, 2006

CAMBA, Salete Valesan. ONGs e escolas públicas. São Paulo: Dissertação de Mestrado, FEUSP, 2004.

CANDIDO, A. "O direito à literatura" In Vários Escritos. São Paulo: Duas Cidades, 1995.

CANDIDO, A. “A literatura e a formação do homem” In Ciência e cultura 24 (9), 1972, p. 803-9.

CERTEAU, M. "Ler uma operação de caça" In A invenção do cotidiano. Petrópolis: Vozes, 1998.

CHARTIER, R. A aventura do livro - do leitor ao navegador. São Paulo: Ed. UNESP Imprensa Oficial do Estado de S. Paulo, 1999.

COELHO, N. N. Literatura Infantil: teoria, análise e didática. São Paulo: Moderna, 2002.

DI PIERRO, M. C. Descentralização, focalização e parceria: uma análise das tendências nas políticas públicas de educação de jovens e adultos. Educação e Pesquisa, SP, jul/dez, 2001, p 321-337.

DRAIBE, S. M. As políticas sociais e o neoliberalismo: reflexões suscitadas pelas experiências latino-americanas. Revista USP, SP, no 17, mar/abr/mai 1993, p 86-101. 
ECO, U. Sobre literatura: ensaios. Rio de Janeiro: Record, 2003.

EITERER, C.L. Uma leitura possível: um estudo sobre a formação do leitor no ensino médio. São Paulo: Tese de Doutorado, FEUSP, 2001.

ENZENSBERGER, H. M. "Elogio ao analfabetismo" In Mediocridade de loucura e outros ensaios. São Paulo: Ática, 1985.

FREIRE, P. Educação como prática de liberdade. Rio de Janeiro: Paz e Terra, 2002.

FREIRE, P. A importância do ato de ler-em três artigos que se completam. São Paulo: Editora Cortez, 2006.

FOOTE-WHYTE, W. Treinando a observação participante. In GUIMARÃES, A.Z. (org.) Desvendando máscaras sociais. Rio de Janeiro: Livraria Francisco Alves Editora, 1980.

FOUCAMBERT, J. A leitura em questão. Porto Alegre: Artes Médicas, 1994.

GADOTTI, M. Organização do trabalho na escola. São Paulo: Ática, 1993.

GALVÃO, A. M. O. \& DI PIERRO, M.C. Preconceito contra o analfabeto. São Paulo: Cortez, 2007.

GOHN, M. G. Educação não-formal e cultura política: impactos sobre o associativismo do terceiro setor. São Paulo: Cortez, 1999.

GÓMEZ, G. R.; FLORES, J.G. e JIMENEZ, E. G. Metodologia de la investigación cualitativa. Málaga: Ediciones Aljibe, 1999.

JAUSS, H. R. "A estética da recepção: colocações gerais" In LIMA, L.C. (org.) A literatura e o leitor. São Paulo: Paz e Terra, 2002. 
JAUSS, H.R. "O prazer estético e as experiências fundamentais da Poiesis, Aisthesis e Katharsis” In LIMA, L.C. (org.). A literatura e o leitor. São Paulo: Paz e Terra, 2002.

JAUSS, H. R. A história da literatura como provocação à teoria literária. São Paulo: Ática, 1994.

KLEIMAN, A. Texto e leitor - aspectos cognitivos da leitura. Campinas: Editora Pontes, 2004.

LANDEIRA, J. L. M. “A aula de língua portuguesa e a formação de leitores” In FROM G. e LIMA- HERNANDES, M.C. (org.). Domínios da linguagem V. São Paulo: Plêiade, 2005.

LIMA, L.C. (org.) A literatura e o leitor. São Paulo: Paz e Terra, 2002.

MACEDO, N. D. \& SEMEGHINI-SIQUEIRA, I. Biblioteca Pública / Biblioteca Escolar de país em desenvolvimento: diálogos entre bibliotecária e professora para reconstrução de significados com base no Manifesto da Unesco. São Paulo: CRB8/FEUSP, 2000.

MARCHETTI, G. N. Leitura e leitor: análise do dizer teórico e do fazer prático em uma proposta avaliativa. São Paulo, Dissertação de Mestrado, Faculdade de Educação da USP, 2005.

MARQUES, M. L. A família e a escola marcando a formação do leitor. São Paulo, Tese de Doutorado, Instituto de Psicologia da USP, 1999.

MARX, K. A ideologia alemã. São Paulo: Martins Fontes, 2002.

MAZZOTTI, A. J. e GEWANDSZNAJDER, F. O método nas ciências naturais e Sociais - Pesquisa Quantitativa e Qualitativa. São Paulo: Pioneira, 1998. 
MELLUCI, A. A invenção do presente, movimentos sociais nas sociedades complexas. São Paulo: Vozes, 2001.

Nomads of the present: social movements and individual needs in contemporany society. Great Britain: Temple University Press, 1989.

"The new social movements: a theoretical approach", in: Social Science Information, 1980, p. 19, 20.

MICHELAT. G. Sobre a utilização da entrevista não-diretiva em sociologia. In THIOLLENT, M. (org.) Crítica metodológica, Investigação social e Enquete Operária. Editora Polis, 1982.

NASCIMENTO, E.M.F.S. \& GREGORIN FILHO, J.N. LDB, ensino superior $e$ construção da cidadania. São Paulo: Editora Plêiade, 2000.

POLIDO, N. E. S. A formação de professores de Língua Portuguesa de $5^{a}$ a $8^{a}$ séries do ensino fundamental: implicações na leitura dos parâmetros curriculares nacionais. São Paulo: Dissertação de Mestrado, FEUSP, 2003.

PROUST, M. Sobre a leitura. Campinas: Pontes, 1989.

SALAMON, L. A emergência do terceiro setor - uma revolução associativa global. São Paulo: Revista de Administração, jan/mar 1998, v. 33, n.1 , p. 5-11.

SCHERER- WARREN, I. "ONGs na América Latina: trajetória e perfil" In Meio Ambiente, desenvolvimento e cidadania: desafio para as ciências humanas, Vários autores. São Paulo: Artes, 1995.

SEMEGHINI-SIQUEIRA, I. Magia/Estética \& Informação: propostas para desenvolvimento de oralidade-leitura-escrita nas práticas de ensino de Língua Portuguesa. São Paulo: FEUSP, 2004. 
O poder do passado nas práticas escolares de

oralidade, leitura e escrita contemporâneas: reconstituição de alicerces para otimizar o grau de letramento/literacia de jovens brasileiros. Anais/Actas. XIV Colóquio da AFIRSE “Para um balanço da investigação da educação de 1960 a 2005”, Lisboa: Universidade de Lisboa/ FPCE.

. Modos de ler textos informativos/virtuais e questões sobre memória: estratégias para alavancar a construção do conhecimento. In REZENDE, N.; RIOLFI, C.; SEMEGHINI-SIQUEIRA, I. (org.) Linguagem $e$ Educação: implicações técnicas, éticas e estéticas. São Paulo: Humanitas, 2006, p. 169203.

SMITH, F. Compreendendo a leitura - Uma análise psicolingüística da leitura e do aprender a ler. Porto Alegre: Artes Médicas, 2003.

SOARES, M. Letramento, um tema em três gêneros. Belo Horizonte: Autêntica, 2003.

STEINER, G. "Em uma pós-cultura” In Extraterritorial - A literatura e a revolução da linguagem. São Paulo: Cia. das Letras, 1998.

TEZZARI, N. S. A constituição do aluno leitor: um estudo etnográfico. São Paulo, Tese de Doutorado, Instituto de Psicologia da USP, 2005.

TFOUNI, L.V. Letramento e alfabetização. São Paulo: Cortez Editora, 1995.

TFOUNI, L.V. Adultos não alfabetizados / $O$ avesso do avesso. Campinas: Pontes, 1988.

THOMPSON, E. P. A formação da classe operária - v. 1 . São Paulo: Paz e terra, 1997. 
TODOROV, T. Introdução à literatura fantástica. São Paulo: Editora Perspectiva, 1990.

TOPALOV, C. Fazer a história da pesquisa urbana: a experiência francesa desde 1965.

In Espaço e Debates. São Paulo: Núcleo de Estudos Regionais e Urbanos, 1988, no. 23, pp.22-23.

TOURAINE, A. O retorno do ator: ensaio sobre sociologia. Lisboa, Instituto Piaget.

. "A sociologia da ação: uma abordagem dos movimentos sociais" In:

Anais do Seminário O retorno do autor. Faculdade de Educação da USP, 1981.

VEJA (edição 1963, ano 39, no. 26 de 5 de julho de 2006)

WOLCOTT, H.W. Criteria for an etnographic approach to research in education. Human organization, 34, 1975, pp. 111-128.

VELHO, G. Observando o familiar. In NUNES, E. O. (org). A aventura sociológica. Rio de Janeiro: Zahar Editora, 1978. 


\section{ANEXO I - PROPOSTA METODOLÓGICA DOS CÍRCULOS DE LEITURA}

\section{I - Objetivo}

Este método busca desenvolver o gosto e o interesse pela leitura entre crianças e adolescentes de baixa renda em comunidades urbanas de periferia.

A leitura tem a função de ampliar o universo cultural-afetivo desses jovens, normalmente bastante restrito. $O$ método aqui apresentado já tem sido aplicado com resultado junto a crianças e jovens em escolas da rede estadual e em centros culturais de bairros da periferia na Grande São Paulo, com apoio do Instituto A e da Fundação $\mathrm{B}^{6}$.

\section{II - Justificativa}

Pode-se constatar, no mundo atual, que ao vertiginoso avanço técnicocientífico, tem correspondido um decréscimo dos valores tradicionais que se revelam na ética, na moral, na religião, nas artes, no convivio social e familiar. De uma forma geral acentua-se a tendência ao individualismo, à supervalorização dos bens materiais, à busca do prazer imediato facilmente descartável e substituivel, ao sucesso rápido. Neste contexto torna-se dificil a formação de uma identidade coerente e segura, que para se consolidar depende de parâmetros firmes, consistentes, constantes. Tais parâmetros nos chegam somente através de uma sabedoria estruturada em séculos e séculos de experiência, de

\footnotetext{
${ }^{6}$ A fim de preservar a identidade da organização retiramos qualquer referência que a possa identificar.
} 


\section{Circulação interna}

história, de contato com a natureza e com o patrimônio cultural que chegou até nós.

A linguagem humana, gravada, falada, escrita sempre se encarregou de difundir, ampliar, imortalizar para a posteridade uma herança inigualável. E é esta que buscamos transmitir a estes jovens e crianças, com os quais entramos em contato. Num primeiro momento nos assustam suas dificuldades de expressão, de comunicação, de imaginação, de entendimento. Mas isto é só num primeiro momento, pois logo descobrimos o quanto eles estavam à espera, ávidos de ter uma oportunidade para refletir e expressar o que sentem. Estão ávidos por alguém que lhes conte histórias, the ensine como refletir, meditar, que lhe fale de suas origens ancestrais. Estão à espera de alguém que se interesse por saber como eles se sentem em relação à outras pessoas. O universo deles é cercado de "nãos". Temos a pretensão de transformálos em "sims". Como? Através do contato, da continência, do reconhecimento deles como seres humanos dignos de afeto e atenção. Nosso principal instrumento: a leitura, a linguagem, o diálogo. A natural curiosidade infantil é logo despertada pelas estórias que contamos, e que eles ouvem, lêem, contam e comentam. Eles começam a exercer a crítica, a discriminação, a avaliação à medida que vão analisando e discutindo o conteúdo dos textos, opinando sobre os seus temas e tentando escrever e redigir seus próprios pensamentos.

$\mathrm{Na}$ leitura e reflexão em grupo, há um momento de perplexidade quando os jovens observam como o livro toca de forma diferente cada um. Através deste embate de diferentes leituras, o jovem vai reconhecendo que o que antes projetava no livro era na verdade parte de si próprio. O grupo e o livro nos ajudam a recuperar o que é o “próprio", o "específico" de cada um. Dentro deste universo, não é mais possivel ver o outro como inimigo, senão como alguém diferente de nós, 


\section{Circulação interna}

que pode nos ajudar na construção do nosso próprio entendimento.

Assim, estamos a caminho de nos humanizarmos; deixando de ver na violência e no crime a única forma de nos auto-afirmarmos, de desenvolvermos nossa auto-estima.

A ONG 67, que aplica este método nas escolas estaduais da periferia, tem como um dos desafios principais mostrar que se queremos ser um país civilizado e desenvolvido inserido no mundo, temos que fortalecer nossas instituições. Queremos passar para os nossos jovens a idéia de que pertencer a uma instituição pode lhes ajudar muito a desenvolverem seus talentos e se darem bem na vida. Precisamos desesperadamente que eles percebam que as instituições são espaços onde eles podem crescer. Precisamos também tirar deles a idéia de que as instituições são espaços rígidos, burocráticos, que lhes tirarão a liberdade. Há idéias geniais, inclusive de artistas, que ficam na gaveta se não encontram apoio de uma instiuição, que tenha uma boa organização.

Para o desenvolvimento deste projeto contamos, obviamente, com recursos humanos, materiais didáticos que especificamos abaixo. Mas é importante frisar que contamos primordialmente com o "milagre" da "Palavra". Os jovens e crianças sempre se envolvem e se encantam com ela, quer venha de textos modernos, quer lhes traga a poesia, os mitos, a literatura clássica, ou então aqueles célebres filósofos que há milênios já discutiam o amor, o conhecimento, o "humano".

\section{III - Histónico}

O método dos Círculos de Leitura aqui proposto foi elaborado por Carina $^{8}$, Bacharel em Filosofia (UERJ) e Psicanalista Membro do

\footnotetext{
${ }^{7}$ A fim de preservar a identidade da organização retiramos qualquer referência que a possa identificar.

${ }^{8}$ A fim de preservar a identidade da organização retiramos qualquer referência que a possa identificar.
} 


\section{Circulação interna}

Instituto Sedes Sapientae (SP), com 25 anos de experiência conduzindo grupos e vários trabalhos publicados sobre a relação entre a Psicanálise e as obras clássicas literárias de autores como Platão e Shakespeare. Ao longo de seu trabalho clínico, Carina observou que muitas pessoas buscavam a terapia por se sentirem sem sentido na vida. Ela constatou que lhes faltava um repertório cultural, um sentimento de pertencer ao mundo, que o contato com os clássicos oferece. Primeiro Carina aplicou o método no manicômio Franco da Rocha, cujo paciêntes foram convidados não para falar dos problemas, mas para ler, se relacionar e se impregnar com os diálogos do Banquete de Platão. O sucesso desta experiência fez com que Carina fosse convidada a levar para outros espaços e congressos seu método, que foi adotado como forma de terapia por profissionais em outras instituições em Campinas, Ribeirão Preto, Curitiba e Fortaleza.

Quando em 2000 a ONG 6 iniciou um programa de mobilização cívica e redução da violência em Diadema, coordenado por seu diretor executivo, Carina foi convidada a aplicar seu método em grupo de adolescentes em uma escola da cidade, lendo Fernão Capelo Gaivota de Richard Bach e O Banquete de Platão por seis meses. A partir de 2002, com a crescente demanda de jovens e o apoio de parceiros como a Fundação B e o Instituto A, o projeto Círculo de Leitura foi introduzido em diferentes escolas da rede estadual. Em 2005 o projeto já atua junto a 24 escolas e um total de 1400 adolescentes em São Bernardo, Diadema e São Paulo. Mesmo nas escolas mais carentes e com problemas crônicos de violência, o método tem sustentado o desenvolvimento de alunos que querem aprender e respondem de forma positiva ao desafio. Apesar de muitos estudantes entrarem no programa com um nível de leitura inferior ao esperado para a sua série, eles se desenvolvem rapidamente. A leitura compartilhada e atividades de escrita e poesia desenvolvem de forma integrada a fluência, o vocabulário e a compreensão de texto. Depois de seis meses, mais de 


\section{Circulação interna}

$70 \%$ dos jovens melhoram suas competências em leitura e análise de texto, de acordo com critérios baseados no Programa para Avaliação Internacional do Estudante (PISA), da OECD. Estes resultados, assim como as transformações no comportamento e nas atitudes de alunos participantes têm estimulado o interesse de professores e novas escolas para adaptar o método e levá-lo a novos alunos e comunidades da periferia.

\section{IV-Metodologia}

A matéria-prima dos Círculos de Leitura é o poder da palavra, do diálogo. É a linguagem transformada em ação. Os seguintes elementos formam o sustentáculo de nosso método:

\section{Pequenos grupos em circulos}

Formamos grupos com no máximo 15 integrantes, em encontros semanais de duas horas. Sentamos em cadeiras, já arrumadas em formato de círculo, em uma sala adequada e silenciosa, e trazemos um livro préviamente escolhido. Primeiro contamos um pouco da estória, no próximo encontro recapitulamos o último encontro. Cada participante lê um parágrafo e a leitura passa para o participante que está a seu lado. Primeiro lemos, depois dizemos o que nos tocou, compartilhando o significado daquilo com os companheiros de grupo. Qualquer um pode interromper a leitura para comentar ou fazer perguntas para o grupo. Utilizamos a forma do círculo porque nele não há ponto privilegiado. Todos podem se ver e se compreender.

Por que em grupo, por que em círculo? Quando se juntam pessoas, forma-se um organismo vivo, um corpo pulsante, com as mesmas características de um indivíduo. Por duas horas breves e intensas nos separamos do espaço e do tempo concreto para viver uma 


\section{Circulação interna}

outra vida. A leitura no círculo promove um estado de suspensão das descrenças que no dia-a-dia nos arrastam e nos imobilizam. Depois desta experiência seremos leitores capazes de perceber, aceitar e fazer, no dia-a-dia e de forma original, novas combinatórias que antes nos pareciam estranhas. Voltamos a nosso cotidiano aquecidos e sensibilizados, passando a saber lidar mais com as situações que se apresentam. Aplicamos o conceito de "corpo de sonhos", de Elaine Fonseca, no grupo, espaço onde se manifestam as energias mais intensas. No grupo recuperamos a nossa ancestralidade. Então, a nossa vida mental e emocional adquire uma complexidade imensa. Tomando consciência do passado, percebendo nossa origens, podemos reconhecer, a partir dele, o novo, inédito, inusitado e original. Elias Canetti sentiu este movimento e assim o descreveu, em A consciência das Palavras:

"E, então, o tempo, o tempo verdadeiramente físico, não se orienta pelo relógio; ele é antes, e no mais das vezes, uma função da atmosfera na qual transcorre"(p. 283).

\section{Tradição oral e correspondências}

No primeiro momento é impossível começar lendo o livro. Contamos um pouco da estória, e depois começamos a leitura em voz alta em grupo. Depois conversamos sobre o que foi lido e voltamos a ler. No final recuperamos os pontos mais marcantes da discussão, e o grupo termina lendo e recitando poesias. Cada encontro é iniciado com uma recapitulação do que se passou no encontro anterior. O coordenador é a memória do grupo. Ele vai relembrando os pontos que foram importantes e recontando a estória do livro. Logo emergem aqueles que lembram, e se reconstrói esta história. Voltamos à tradição oral - ao 


\section{Circulação interna}

imenso prazer de ouvir e contar estórias - para nos aproximarmos dos livros, e voltarmos à ela com as poesias, nossos grandes aliados que sabemos de cor. As pessoas que coordenam os grupos de Círculo de Leitura têm muito prazer em contar as estórias dos livros. Elas sabem que contar uma estória é uma forma sutil de passar conhecimento. Quando você é tocado por uma estória, você sente uma necessidade muito forte de passar, de compartilhar esta descoberta. Elas descobrem que cada vez que contam uma estória contam de forma diferente. E é só contando que vão aprendendo, assimilando. Quando uma estória lhe toca profundamente, você se sente movido a contá-la.

Contar uma estória emplica vivenciá-la. E como as estórias fazem parte da vida, elas têm também partes dolorosas, dificeis. Percebemos que em muitas famílias os adultos não querem contar reviver o que passaram para seus filhos e netos. Assim, imaginam que os estão poupando. Em um filme que normalmente vemos e discutimos em grupo, Os narradores de Javé de Eliane Caffé, uma comunidade inteira se mobiliza para construir sua história, na tentativa de não desaparecer. E, como diz Adélia B. de Menezes, sobre a função do passado, ao analisar o filme Blade Runner de Ridley Scott:

A grande questão do filme é da criação de uma história de vida para cada um dos replicantes (andróides), de atribuir-lhes um passado, aquilo que Freud chamaria de romance familiar de cada um. "Memórias. Você fala de memórias. Replicantes não têm memórias. Replicantes não têm famílias.", diz Deckard... "Se lhes for dado um passado, será criada uma base para a emoção", é a resposta do policial Bryant. $(128,129)$

Para Susanne Langer, a função da arte está em liberar uma forma emocional de conceber. A leitura em voz alta promove uma livre 


\section{Circulação interna}

associação de idéias que desperta o saber que está em cada um. O bem estar trazido pela experiência da leitura compartilhada é expresso por jovens participantes como João Paulo, participante de 19 anos, que conta:

No grupo, você consegue chegar a mais possibilidades do que sozinho. Eu li a Odisséia sozinho antes de participar dos Círculos - tanta coisa passou ali e eu não tinha percebido...Então, lendo em grupo dá para perceber mais coisas, porque cada pessoa vê o livro de um ângulo diferente e, falando e ouvindo, você vai percebendo mais coisas. (Entrevistas, 15/01/2005)

Nossa primeira atitude em relação a um texto não é a crítica, mas a observação reverente. Se não acreditamos no autor quando o lemos, se não reverenciamos a obra que estudamos juntos, não sentimos a alegria e o conforto necessário para usufruirmos de sua verdadeira essência. As críticas geram um desvio da obra, o enrijecimento de uma determinada opinião sobre ela e, ao invés de se criar um trabalho com o texto se cria um outro tipo de estrutura, paralela a ela, que afasta aqueles que não são experiêntes o suficiente de sua verdadeira essência. Buscamos o universo primário da obra (não o secundário criado pela crítica) pois é ele que nos permite sentir a emoção e a partir dela dar significado ao mundo. Nas palavras de Elaine Fonseca, entendemos que "se as formas significantes veiculam concepções emocionais, conhecer seu fundamento implica ter acesso a uma outra forma de conhecer que não a de predomínio intelectivo"(p.79, 1993)

Criamos um espaço para a poesia, para o som das palavras entrar em nós, em suas múltiplas manifestações. Quando criamos um espaço adequado e vamos lendo o livro em grupo, o autor se apresenta, se faz presente. Nos Círculos costumamos dizer que quando fazemos uma citação, marcamos um encontro com o autor - "cita" em espanhol 


\section{Circulação interna}

significa "marcar encontro". Quem trabalha conosco sabe que o autor não recusa o convite, ele vem ao encontro. Ao compartilharmos as idéias, entramos no estado de devaneio criativo, em que as obras de arte são compreendidas - prendidas dentro de nós - não pelo saber racional, mas pelos sentidos, pelo corpo. Neste estado, a conversa nunca se esgota. Isto encanta os jovens, como conta nossa educadora, Janaína, que era multiplicadora na época dessa entrevista:

Eu não sei por que, mas essa questão de vocês quererem saber o que eu estou pensando, o que me desperta mais no livro, foi me instigando mais e eu fui me aprofundando. Quando eu percebi que isso me ajuda não só dentro dos Círculos de Leitura, mas também fora, eu entrei de cabeça mesmo. (Entrevista, $10 / 03 / 2005)$

\section{Preparo para o inesperado e para os paradoxos}

O intenso compartilhamento de idéias e opiniões faz com que seja impossível prever o que vai acontecer no grupo.O coordenador sabe que o conhecimento novo desorganiza o anterior, cria um caos. Depois de vivida esta desorganização, cria-se espaço para a idéia nova. Assim, não planejamos uma discussão, mas nos preparamos para ela. Este preparo - lendo o texto, identificando pontos importantes, lendo outros textos que tratem dos mesmos temas - é o que permite que possamos perceber o quanto o diferente se apresenta. É aí que percebemos o trabalho produzido, que emergiu do grupo.

Por mais que as opiniões dos participantes de um grupo sejam divergentes, nenhuma delas está certa ou errada. O importante é respeitar os sentimentos que geram cada idéia. No grupo sempre emerge um líder que naquele momento é capaz de conciliar os pontos de 


\section{Circulação interna}

vista. O nosso desafio é tolerar essas diferenças e sustentar o pardoxo, como em $O$ Catador de Pensamentos de Mônica Feth, um dos primeiros contos que trabalhamos. Nele o Catador de Pensamentos acorda bem cedo de mnhã e sai pela cidade, recolhendo em sua sacola todos os tipos de pensamentos: inteligêntes, amalucados, bobos, desastrados, tímidos. Ele os leva para sua casa, os desembaralha, os coloca em ordem alfabética em uma prateleira, e vai descansar. Só depois os planta, lava as mãos até limpar o último grão e vai dormir porque confia na terra. Quando acorda vai ao jardim e vê aqueles pensamentos se transformarem em flores maravilhosas que exalam um único perfume. Ele senta na espreguiçadeira, imóvel, sabendo que haverá mais um momento de transformação. Aquele perfume vira música, se transforma em partículas de pensamentos que se elevam e vão penetrar nas cabeças das pessoas enquanto elas dormem. Esta metáfora representa nosso trabalho pois tais pensamentos "perdidos" representam para o jovem a sua "pulsão", sua energia. Em si mesma anárquica, ela é canalizada e encontra seu destino no grupo, tendoo educador uma função análoga ao do Catador.

\section{Poesia e fluxo de idéias}

Ao final de cada atividade de leitura lemos uma poesia em voz alta, repetidas vezes, para que possamos aprender sua sonoridade, musicalidade, seu ritmo, já que, como Octavio Paz diz, a fonte da poesia é a vida - a poesia e o pensamento são um sistema único. Assim, utilizamos o ritmo da criação poética como agente da sedução para que os jovens fiquem impregnados das palavras dos autores, que o som das palavras ressoe dentro de cada um e se sintam suas correspondências. Incentivamos os participantes a decorar suas poesias preferidas, pois acreditamos ser isto um instrumento para adquirir conhecimento. Além 


\section{Circulação interna}

disso, uma poesia é fácil de ser memorizada. Esta prática também tem a função de nos ensinar como respirar e fazer pausas ao falar. Somos da opinião do filósofo Miguel de Unamuno, que o homem sem medo é aquele cujo ritmo do coração bate ao ritmo do universo.

Além da poesia no encontro, selecionamos trinta poesias e sugerimos que os participantes leiam só uma a cada noite antes de dormir. Ao terminar toda a coletanêa, sugerimos que recomeçem a

leitura, desta vez no ritmo e do jeito que quiserem, em voz alta, baixinho, para alguém ou somente para si. Algumas folhas em branco são incluídas para que o jovem anote conclusões, sentimentos, sonhos que teve durante a noite após a leitura. Quando recomeçam a ler sentem uma surpresa e um prazer muito grande que uma segunda leitura traz.

Depois muitos participantes começam a produzir suas próprias poesias e trazê-las para o grupo, espontaneamente ou seguindo o exemplo de outros participantes que mostram suas criações. Como explica o participante Davi, de 15 anos:

Comecei a escrever poesia depois do Círculo. Talvez eu já escrevesse, mas não com tanta sensibilidade, com tanta emoção como eu passo nas minhas poesias agora. Acho que é mesmo esta questão da sensibilidade, de saber lidar com as palavras certas. Até então, eu jogava as palavras no papel e criava uma redação para a professora. Era limitado, porque era algo que eu guardava para mim. E nos Círculos, além de eu estar aprendendo a lidar com essa sensibilidade das palavras, pegando uma situação do cotidiano e pondo no papel de uma forma poética - isso eu aprendi nos Círculos, que é questão de sensibilidade - foi muito bom porque até o meu jeito de pensar a escrita me auxiliou em 


\section{Circulação interna}

tudo, em estar lidando com as pessoas, com a vida. (Entrevista, $7 / 06 / 2005)$

É uma vivência de poesia onde encontramos condensado todo o método dos Círculos de Leitura, tudo aquilo que fazemos durante a nossa convivência. Trata-se do exercício "Fluxo das idéias, Fluxo da consciência”, que se resume nos seguintes passos:

$1^{\circ}$. A partir de diversas poesias de autores variados sobre temas múltiplos, cada participante do grupo escolhe uma delas para ser lida em voz alta.

$2^{\circ}$. Cada um dos participantes escolhe dois versos, de alguma poesia lida, ou das próprias poesias;

$3^{\circ}$. O grupo escolhe alguém para ser o escrivão, que irá anotar o que foi dito por todos.

$4^{\circ}$. Os participantes mentalizam os versos escolhidos até sentílos integrados no corpo. A energia é vida, e procede do corpo. A razão envolve esta energia como uma circunferência. Assim, estamos prontos para o exercício.

$5^{\circ}$. Sem determinar de antemão quem vai começar, depois de um tempo de silêncio, alguém inicia, falando para o grupo um de seus versos. Ouvimos, respiramos, os recebemos, nos aquietamos. Quem sente que é o momento para o seu verso, o diz, assim o exercício prossegue, cada um dizendo o seu verso ao tempo que sentir como adequado. As pessoas podem alternar de um a outro verso que escolheram quando sentirem que é melhor, e podem falar divversa vezes o seu verso.

$6^{\circ}$. Não é determinado de antemão quem irá terminar a poesia, nem como isso será feito. Quando alguém coloca a sua frase e se faz um 


\section{Circulação interna}

longo silêncio, sente-se que a poesia chegou ao seu fim, ao seu término. Ela nasceu, a poesia aconteceu. O escrivão então lê para o grupo a poesia coletiva.

Quando o escrivão escolhido para ser o corpo do grupo lê a poesia recém nata, todos se surpreendem, ficando maravilhados com a criação, Muitas vezes percebemos que essa poesia pode ser lidas em diversas direções, quer seja de cima para baixo, ou de baixo para cima. O ganho é percebido por todos naquele instante. Podemos dizer que o grupo é um sonho, que sonha a sua poesia. E, ao mesmo tempo, a poesia também sonha seu grupo. Acreditando na idéia de que os livros são sonhos, devaneios, para adentrar e interpretar seu sentido profundo é necessário criar um espaço de sonhos. Utilizamos esse exercício por acreditarmos que o espaço do grupo é a liberdade do devaneio. Queremos esse encontro direto com a magia, com a arte. Neste espaço se rompem as barreiras que separam um eu do outro eu, desaparecem as hierarquias, e isso cria um estado de bem estar que libera a imaginação, e os sentimentos mais variados estão em liberdade de entrar em novas combinatórias. O que conta é a fusão dessas diversas emoções, que se transformam em poesia penetrando no sonhador que somos nós, participantes desse grupo - espaço de criação. A alma, desperta para os poderes poéticos do psiquismo humano, encontra, assim, seu mundo no mundo.

É preciso que os participantes segurem a pulsação, a intensidade do coração, para que o "escrivão" corporifique, capte, escreva, inscreva as idéias; se falamos juntos, muito rápido, ele não consegue captar, escrever, e alguma idéia se perde. Muitas vezes é preciso recomeçar repetidamente, porque a palavras se embaralham; as palavras pulsam, tomam vida própria, querem chegar cedo demais ao corpo do escrivão; necessitamos organizá-las dentro de nós para caber na "matéria" que é representada pelo corpo e as mãos do “escrivão". É um exercício que 


\section{Circulação interna}

visa tanto sentir o ritmo do nosso corpo, como captar também o ritmo dos outros participantes, entrar em sintonia com os demais membros do grupo. Se em algum momento, duas pessoas falam juntas, se olham e decidem naquele instante quem vai ceder, qual verso vai ser pronunciado, preservando assim a sintonia. Assim, o exercício continua e a poesia vai sendo tecida.

Nesta vivência encontramos a essência do nosso método. O que sustenta o trabalho dos Círculos de Leitura é oferecer a possibilidade de promover essas formações grupais do psiquismo humano, que se manifestam quando lemos nos deixando conduzir pelo fluxo das idéias, das palavras, que um determinado texto promove. Entramos neste estado de "devaneio criativo", essa atividade onírica na qual se mantém uma clareza de consciência. Assim, formamos esse "todo", essa mente grupal que está em nós, mas a reconhecemos com mais facilidade quando a deixamos manifestar-se fora de nós. É esse mundo além de nós, eterno presente sempre recriado que nos enraíza e ilumina nosso cotidiano. Assim, a razão encorpada ganha asas, tocando a palavra poética, palavra de base, raiz de nossa ancestralidade.

\section{Obras escolhidas}

Escolhemos obras daqueles escritores que conseguiram entrar em contato com as profundezas da alma humana, colocando no papel este universo imenso que é o homem. Freud fala desse gênero de escritores, que não inventam, que não criam o seu material. São aqueles que retomam temas universais, que sobrevivem ao tempo. Este material que não é novo procede do tesouro popular dos mitos, lendas e contos de fadas. Para os Círculos escolhemos estas obras, que nos possibilitam retomar estes temas, recomeçar pelos fundamentos, pelas origens. As estórias que escolhemos têm o dom do encantamento, do deslumbramento. Ao conseguir entrar nelas, os jovens fazem uma 


\section{Circulação interna}

viagem a um outro tempo, cheio de imagens, mitos e metáforas. Como os sonhos, os mitos se utilizam de imagens simbólicas, que não são apenas do sonhador, mas pertencem a um patrimônio coletivo, à rica experiência da humanidade. Muitos dos escritos de Freud examinam as fontes da capacidade criadora do artista e a misteriosa interação do escritos com o leitor:

A meu ver, o que nos prende tão poderosamente só pode ser a intenção do artista, até onde ele consegue expressá-la. Percebo que isso não pode ser simplesmente uma questão intelectual; sua intenção é despertar em nós a nossa atitude emocional, a mesma constelação mental que nele produz o ímpeto de criar.

Sem dúvida quando o autor começa a sua obra, tem planos do que pretende contar, mas na medida que vai escrevendo, os personagens ganham vida própria, o conduzem. Assim a obra vai além da proposta inicial do seu autor. Em uma conferência disseram a Thomas Mann que seu livro A montanha mágica era um livro pedagógico. Ele respondeu "Eu não sabia que eu era capaz de tanto espírito". Também disse que "enfrentar o mítico é a grande tarefa, a tarefa escolhida pelos grandes escritores e me pergunto se a novela, ao encontrar-se no seu climax volta-se para suas fontes e revela a sua essência originária"

Assim, valorizamos os clássicos da literatura porque eles oferecem aos jovens um repertório de temas e valores que o apóiam na transição para a vida adulta, permitindo-o relacionar dilemas e situações do diaa-dia com temas, heróis, valores, idéias e condutas que sobrevivem ao tempo. Como preparação para estes livros, começamos as novas turmas lendo estórias belas com temas que se remetem aos clássicos, como Fernão Capelo Gaivota de Richard Bach, A Chave do Tamanho e outras obras de Monteiro Lobato, O Pequeno Príncipe de Antoine de Saint- 


\section{Circulação interna}

Exupéry, O Conto da Ilha Desconhecida de José Saramago, além de contos selecionados de Machado de Assis (O Apólogo, O Espelho), Cecília Meireles (A Arte de Ser Feliz), Mônica Feth (O Pintor, a Cidade eo Mar; O Catador de Pensamentos), Rubens Alves (A Menina e o Pássaro Encantado), Gabriel Garcia Márquez (O Afogado mais Bonito do Mundo), Marina Colassanti (A Moça Tecelã) e Clarice Lispector (Felicidade Clandestina). Entre as obras utilizadas se encontram $O$ Banquete de Platão, A Odisséia de Homero, Romeu e Julieta e Otelo de William Shakespeare, textos de Nietzche ( As três Transformações do Espírito, Assim Falou Zaratustra) Sidarta de Herman Hesse, O Velho e o Mar de Hemingway, Robinson Crusoe de Daniel Defoe.

Os livros são trabalhados sistematicamente e não são muitos, porque queremos aprofundar os temas. Além disso, faz parte do método aprender a demorar-se. Só assim se pode a/prender a transmitir e falar das profundezas de uma obra, de forma simples e familiar, que pode tocar aquele que está ouvindo. Deste modo atingimos uma das tarefas primordiais de que nos fala Elias Canetti: "Criar mais e mais espaços dentro de si próprio...espaço para o saber...espaço para os seres humanos, com os quais se vivência”.

\section{Memória do grupo}

Observamos que em cada encontro no momento da conversa os participantes ficam muito animados com as novas idéias produzidas no calor da discussão, na livre associação. Mas nos próximos costumam chegar até nós muito desmemoriados, não conseguem recapitular as idéias discutidas, lembrar a estória, contar para os outros. O nosso desafio é que estas idéias sejam lembradas e transportadas para outros grupos e encontros. Nos Círculos, a memória individual se fortalece e se expande a partir da memória do grupo. A narrativa é o fluxo da reconstrução da memória, como descreve Flávio Aguiar, ao nos lembrar 


\section{Circulação interna}

de que o mundo, quando decifrado pela linguagem e reconstruído pela memória, possui um princípio de positividade. Por isso em nosso trabalho assumimos a função que a repetição das histórias infantis das tradições orais assumem, como explica Eliane Fonseca em Corpo de Sonho:

Neste ponto podemos nos lembrar da função da repetição nas histórias infantis das tradições orais que as crianças exigem lhes sejam contadas infindáveis vezes, com os mesmos detalhes. A repetição teria aqui a função de criar uma memória, de estabelecer traços mnêmicos, marcas que serão matizes de outros traços e marcas prospectivas, a serem criadas, como que matrizes míticas. (57)

Cada grupo e cada encontro dos Círculos têm uma identidade, um ambiente, um modo de ser. Essa experiência nos prepara para reconhecer e lidar com outros grupos, e com a imprevisivel combinação de emoções e temas que a leitura em voz alta e a discussão reverente despertam. É a abertura para o novo. Já explicamos que quando lemos juntos, somos visitados pelo autor do texto, que se expressa através da obra que criou. Compartilhando tantas idéias, entramos no estado de devaneio criativo pelo encantamento e desenvolvemos os sentidos, uma forma de conhecimento essencial no primeiro momento.

Quando sabemos lembrar e contar bem as histórias, o poder da narrativa nos apóia para criarmos nosso conhecimento, colocando as emoções em palavras. Ao contar estas histórias e ler estas poesias, criamos um fundo imaginário comum, uma unidade imaginária. Esse fundo comum é essencial, pois apóia e sustenta as divergências e promove a criatividade. Como cada encontro dos Círculos tem sua história, precisamos que educadores e multiplicadores nos ajudem a ser a memória do grupo, dividir nossas experiências e circular as idéias que 


\section{Circulação interna}

nos aparecem em cada encontro. Lembramos o que foi conversado, as idéias que surgiram, as dúvidas, os temas, como se estivéssemos contando para um outro aluno ou educador, que não pôde participar mas está com muita vontade de conhecer. Os educadores e multiplicadores selecionados conhecem bem os textos trabalhados, podem falar sobre o texto e contar sua história de cor, além de relacionar trechos com outras obras de nosso repertório, transmitindo as idéas contidas nele. Os educadores e multiplicadores que trabalham conosco são aqueles capazes de ser mensageiros, transportar a estória, as idéias no corpo e, porque não dizer, na sua alma.

\section{Visitar e hospedar}

Quando lemos juntos, somos visitados pelo autor do texto, que se expressa através da obra que criou. Merleau Ponty já disse que não somos nós que olhamos uma obra de arte, um quadro, um texto. É a arte que nos toca. Sua presença, sua energia, ao penetrar dentro de nós, nos desorganiza, desorganiza o nosso mundo interno. Passamos um tempo até poder acomodar o novo que entrou em nosso ser. Nos grupos, observamos que aquelas pessoas que conseguem ficar à vontade no grupo e se deixar impregnar pela obra conseguem se transformar.

Lendo A Odisséia de Homero, aprendemos que sobre a importância que os gregos davam à hospitalidade, ao viajar, e como ofereciam presentes aos hóspedes. Ë no contato com os outros que nos humanizamos, desenvolvendo as nossas potencialidades. Para os jovens e crianças, ser um bom anfitrião ou visitante pode ser difícil, pois não estão acostumados com esta cultura. Percebemos que os jovens tendem a se isolar dentro de sua própria casa, sua escola, e não conhecem muitas vezes os seus próprios vizinhos. É comum também que nunca tenham saído de seu bairro ou vindo a São Paulo. 


\section{Circulação interna}

O conto de Gabriel Garcia Márquez, O Afogado Mais Bonito do Mundo, que lemos em nossos grupos, ilustra este processo. Nele, conhecemos um pequeno vilarejo de pescadores, tão pequeno que toda a sua população cabia em sete botes. Até que um dia suas crianças estão brincando na praia e encontram um coberto de algas. Quando as mulheres se aproximam, lhe basta um olhar para ver que era um afogado que não era dali. Elas o recolhem, e, à medida que o vão limpando, preparando-o para um funeral, vão contemplando-o até lhe dar um nome, Estevão. Imaginam sua estória. Os homens, primeiro desconfiados, e ciumentos das atenções das mulheres, o olham com mais cuidado e se dão conta que ele não veio para atrapalhar, que entende a angústia deles, estes pescadores que ficam tantas noites distantes de suas esposas, longe, no alto-mar. O vilarejo se transforma profundamente. Depois de receber o afogado Estevão, passam a se preparar para acomodar bem o próximo visitante que vier. Plantam flores nas escarpas, para se fazerem atraentes, constrem casas mais sólidas, e portas mais altas para deixar os outros entrarem. É uma cultura da hospitalidade e da visitação que também desenvolvemos em nossos grupos. Queremos estar sempre preparados para receber o visitante, porque ele sempre traz um outro conhecimento.

Desde os primeiros encontros de um grupo dos Círculos de Leitura, construímos um ambiente adequado onde sempre aparecem visitantes. Quando o visitante chega, lhe contamos a estória que estamos lendo, e logo ele vai entrando no grupo, fazendo associações. No primeiro momento nós - os educadores e multiplicadores - somos o Afogado Estevão que chega, Depois, levamos outros educadores, multiplicadores e pessoas interessadas no projeto para visitar o grupo que se forma.

Os grupos nos Círculos que se iniciam nas escolas e espaços culturais/comunitários são fixos. Lêem um livro com um educador e um multiplicador, e recebem visitas. Estes grupos fixos necessitam de 


\section{Circulação interna}

visitas, senão se fecham. Nos Círculos, ter muitos grupos lendo a mesma obra faz parte da nossa estratégia. Observamos o susto que alguns jovens experimentam ao verem-se desta forma desafiados a pensar na diversidade de possibilidades que um livro oferece, e que nunca se esgota. Já outros jovens sentem uma alegria, um deslumbramento profundo. Os livros clássicos sofreram muitas transformações. Cada geração lhes dá uma nova roupagem, descobre novos sentidos. Estes livros têm um efeito cumulativo e o dom das metamorfoses, como Proteu na Odisséia de Homero. Eles podem tomar muitas formas, dependendo do tempo em que vivemos e da configuração do grupo no qual é discutida a obra. O nosso trabalho é justamente mostrar estas infinitas formas que pode tomar um livro. Constatamos que desta convivência emergem futuros multiplicadores e educadores. A poesia de Heidegger em "Da experiência do pensar" fala por nós:

Nós nunca chegamos aos pensamentos.

Eles vêm a nós.

É a hora conveniente para a conversação.

Isto nos dispõe para a meditação em comum. Esta nem considera o opinar contraditório, nem tolera o concordar condescendente.

O pensar permanece firme ao vento da coisa.

De uma tal convivência talvez alguns surjam como companheiros no ofício de pensar

A fim de que inesperadamente um deles

Se torne mestre

\section{V - Principais Recursos Materiais}

Principais recursos materiais incluem: 


\section{Circulação interna}

- Sala silenciosa em ambiente adequado, sem interrupção ou circulação de pessoas

- Cadeiras que possam ser organizadas em círculo

- Livros - cópias de um mesmo título para que cada participante tenha um exemplar durante o encontro (ver lista de livros utilizados)

- Folhas de papel em branco

- Coletânea de contos selecionados

- Canetas

- Coletâneas de poesias selecionadas

- Fitas e gravador

\section{VI - Recursos Humanos}

Para nós o conhecimento se dá na relação. As pessoa escolhidas para trabalhar como educadores e jovens multipplicadores nos grupos são aquelas que gostam de trabalhar com outras pessoas e que sentem que a coisa mais importante do mundo é a relação humana. Elas sabem que os livros nos apóiam na descoberta de quem somos e que, mais que conduzir precisam se deixar conduzir pela obra.

Os grupos são portanto coordenados por educadores que, conhecendo o método, têm habilidades necessárias para orientar este trabalho. Alguns participam de outros grupos dos Círculos de Leitura e se entusiasmaram, manifestando o desejo de transmitir sua experiência para crianças e jovens através de nosso método. Os educadores são auxiliados por multiplicadores, adolescentes que são participantes de outros Círculos de Leitura e emergem nos grupos como voluntários por sua afinidade com o método, aprendendo a praticá-lo na prática. Os educadores e multiplicadores selecionados conhecem bem os textos trabalhados, podem falar sobre o texto e contar sua história de cor, 


\section{Circulação interna}

além de relacionar trechos com outras obras de nosso repertório, transmitindo as idéias contidas nele.

Selecionamos pessoas que conseguem colocar em prática as cinco habilidades de que nos fala Fernando Pessoa em Mensagem, condições sem as quais os símbolos serão mortos para o intérprete, "e ele, um morto para eles": a simpatia, a inteligência, a intuição, a compreensão e o que Pessoa chama de "graça". Assim, o educador tem que ter simpatia pelos livros que se propöem a interpretar, pois "a atitude cauta, a irônica, a deslocada - todas elas privam o intérprete da primeira condição para poder interpretar". Por intuição entendemos "aquela espécie de entendimento com que se sente o que está além do ssimbolo, sem que se veja”. A compreesão permite que o livro seja "iluminado por várias luzes, relacionado com vários outros símbolos". A quinta, deixamos para o próprio Pessoa descrever:

A quinta é menos definivel. Direi talvez, falando a uns, que é a graça, falando a outros, que é a mão do Superior Incógnito, falando a terceiros, que é o Conhecimento e Conversação do Santo Anjo da Guarda, entendendo cada uma destas coisas, que são a mesma da maneira como as entendem aqueles que delas usam, falando ou escrevendo. (16)

\section{VII - Conclusão}

"Tudo vale à pena, Quando a alma não é pequena” Fernando Pessoa

Não se trata de um retorno nostálgico à cultura, mas de um investimento criativo nos livros clássicos, que resistem à passagem do tempo. Esses livros deram origem aos termos que usamos na vida 


\section{Circulação interna}

diária, criando conceitos e noção de realidade e fantasia. Sem contato com esses conhecimentos ficamos sem repertório, limitados, repetindo modos de funcionamento sem compreendê-los. Dessa forma nossas palavras, nossos gestos não têm consistência, são ocos, não se apóiam nem refletem a longa experiência humana.

Nossa tarefa é ensinar-lhes a ler segundo uma técnica na qual a palavra escrita se faz corpo, resgatando a essência na sua plenitude, transitando do espaço individual para o coletivo, resgatando a tradição na sua origem. Como Fernando Pessoa escreve em relação à língua natal "uma língua que se possua de dentro, isto é, com os pensamentos formados organicamente nela", a língua a que nos referimos é uma língua orgânica, os sentidos que emanam do corpo são órgãos do conhecimento. O dizer emerge da relação com os outros. Aprender a ler implica ver, ouvir, entender, enfim, utilizar todos os nossos sentidos. Tudo isso assume outra dimensão na medida em que esses conhecimentos são transmitidos, e o meio é a linguagem. A linguagem é ação, e gesto criativo, ou seja, a linguagem faz o homem. Ela revela o caráter histórico através do qual se exprime o sentimento, a voz de toda uma nação. 


\section{Circulação interna}

\section{BIBLIOGRAFIA DE APOIO}

AGUIAR, Flávio. As questões da crítica literária. In: MARTINS, Maria Helena (org) Rumos da crítica. São Paulo, Senac, 2000.

ARENDT, Hannah. A Permanência do Mundo e a Obra de Arte. In: $A$ Condição Humana. Forense/Salamandra/EDUSP.

BENJAMIN, Walter. O Narrador: Considerações sobre a obra de Nikolai Leskov. In Obras Escolhidas. $3^{a}$ ed. São Paulo, Brasiliense.

BONNEFOY, Yves. Observações sobre o ensino da poesia. In: MORRIN, Edgar (org) A Religação dos saberes: O desafio do século XX!. Bertand Brasil, 2001.

CALVINO, Italo. Por que ler os clássicos. São Paulo, Companhia das Letras, 1993.

CANNETI, Elias. A consciência das palauras - Ensaios. São Paulo, Companhia das Letras, 1990.

ELIOT, T.S. Tradição e talento individual. In: Ensaios. Art Editora, 1989.

FONSECA, Eliane Accioly. Corpo-de-sonho: arte e psicanálise. São Paulo, AnnaBlume, 1998.

A palavra in-sensata. Poesia e Psicanálise.

São Paulo, Escuta, 1993. 


\section{Circulação interna}

FREUD, S. Escritores criativos e devaneios. In: Edição Standard brasileira das obras completas de Sigmond Freud. Vol IX. Rio de Janeiro, Imago, 1969.

GIL, José. O espaço interior. Lisboa, Ed. Presença, 1994.

HEIDEGGER, Martin. Da experiência do pensar. Petrópolis: Globo, 1968.

LANGER, S.K. Sentimento e forma. Trad. Dirigida por J. Guinsburg. São Paulo, Perspectiva, 1980.

MANN, Thomas. Ensaios de Thomas Mann. São Paulo, Perspectiva, 1994.

MENEZES, Adélia Bezerra. Do poder da palavra: Ensaios de literatura e psicanálise. São Paulo, Livraria Duas Cidades, 1995.

OGDEN, Thomas. Uma questão de voz na poesia e na psicanálise. In: Revista Brasileira de Psicanálise. V1 32, No 3, 1998.

PAGÉS, Catalina \& LIMA, Tereza. Oficina de criatividade: o mundo além das palavras. Revista da SPAGESP, No 2, 2001.

PESSOA, Fernando. Mensagem. São Paulo, Martin Claret, 1998. 
ANEXO II - ROSA, J.G. "Seqüência", In: Primeiras Estórias. Rio de Janeiro: Nova Fronteira, 2005, p 107 - 111.

\section{Seqüência}

$\mathrm{Na}$ estrada das Tabocas, uma vaca viajava. Vinha pelo meio do caminho, como uma criatura cristã. A vaquinha vermelha, a cor grossa e afundada - o tom intenso de azamar. Ela solevava as ancas, no trote balançado e manso, seus cascos no chão batiam poeira. Nem hesitava nas encruzilhadas. Sacudia os chifres, recurvos em coroa, e baixava testa, ao rumo, que reto a trazia, para o rio, e - para lá do rio - a terras de um Major Quitério, nos confins do dia, à fazenda do Pãodolhão.

No Arcanjo, onde a estrada borda o povoado, foi notada, e, vendo que era uma rês fujã, tentaram rebatê-la; se esvencilhou, feroz, e foi-se, porém. De beira dos pastos, os anús, que voavam cruzando-a, desvinham de pousar-lhe às costas. No riachinho do Gonçalves, quase findo à míngua d'água, se deteve para beber. Deram tiros, no campo, caçando às codornas. Latidos, noutra parte, faziam-na entrar oculta no cerrado. Ora corriam dela umas mulheres, que andavam buscando lenha. Se encontrava cavaleiros, sabia deles se alonjar, colada ao tapume, com disfarces: sonsa curvada a pastar, no sofrido simulamento. Légua adiante, entanto, nos Antônios, desabalava em galope, espandongada, ao passar por currais, donde ouvia gente e não era ainda o seu termo. Tio Terêncio, o velho, à porta de casa, conversou com o outro: - “Meo fi'o, q'vaca qu'é essa?” - “Nho pai, e’a n'é nossa, não." Seguia, certa; por amor, não por acaso.

Só, assim, a vaquinha se fugira, da Pedra, madrugadamente entre o primeiro canto dos melros e o terceiro dos galos - o sol saindo à sua frente, num céu quase da sua cor. Fazia parte de um gado, transportado, de boiadeiros, gado de coração ativo. Viera do Pãodolhão - sua querência. Apressava-se nela o empolgo de saudade que adoece o boi sertanejo em terra estranha, cada outubro, no prever os trovões. 
Apanhara a boca-da-estrada - para os onde caminhos - fronteando o nascente.

Soada a notícia, seo Rigério, o dono da Pedra, disse: - "Diaba". Ele era alto, o homem, para tão pequenina coisa. Seus sabedores informavam: que a marca sendo a de grande fazendeiro, da outra banda, distante. Seus vaqueiros, postos, prontos. Esse seo Rigério tinha os filhos diversos, que por em volta se achavam. Nem deles, para o quê, havia a necessidade. E vede de que maneira tudo então se passou.

Só um dos filhos, rapaz, senhor-moço, quis-se, de repente, para aquilo: levar em brio e tomar em conta. Atou o laço na garupa. Disse: "É uma vaquinha pitanga?" Pôs-se a cavalo. Soubesse o que por lá o botava, se capaz. Saiu à estrada-geral. Ia indo, à espora leve. Ia desconhecidamente. Indo de oeste para leste.

Já a vaca. O avanço, que levava, não se lhe dava de o bastante. Ante o morro, a passo, breve, nem parava para os capins dos barrancos: arrancava-os, mesmo em marcha, no mesmo surdo insossego. Se subia - cabeceava, num desconjuntado trabalho de si. Se descia - era beiraabismos, patas abertas, se borneando. Após, no plano, trotava. Agora, lá num campal, outras vacas se avistavam. Olhava-as: alteou-se e berrou - o berro encheu a região tristonha. $\mathrm{O}$ dia era grande, azul e branco, por cima de matos e poeiras. O sol inteiro.

Já o rapaz se anorteava. Só via o horizonte e sim. Sabia o de uma vaquinha fugida: que, de alma, marca o rumo e faz atalhos querençosa. Entrequanto, ele perguntava. Davam-lhe novas da arribada. Seu cavalo murça se aplicava, indo noutra forma, ligeiro. Sabia que coisa era o tempo, a involuntária aventura. E esquipava. Ia ao longo, longo, longo. Deu patas à fantasia. Ali, escampava. Tempo sem chuvas, terrentas campinas, os tabuleiros tão sujos, campos sem fisionomia. O rapaz ora se cansava. Desde aí, o muito descansou. Do que,após, se tormentava. Apertou.

Com horas de diferença, a vaquinha providenciava. Aqui alta cerca a parou, foi seguindo-a, beira, beira. Dava num córrego. No córrego a vaquinha entrou, veio vindo, dentro d'água. Três vezes 
esperta. Até que outra cerca travou-a, ia deixando-a desairada. Volveu irrompida ida: de um ímpeto então a saltou: num salto que queria ser vôo. Vencia. E além se sumia a vaca vermelha, suspensa em bailado, a cauda oscilando. O inimigo já vinha perto.

O rapaz, no vão do mundo, assim vocado e ordenado. Ele agora se irritava. Pensou de arrepender caminho, suspender aquilo para mais tarde. Pensou palavra. $\mathrm{O}$ estúpido em que se julgava. Desanimadamente, ele, malandante, podia tirar atrás. Aonde um animal o levava? O incomeçado, o empatoso, o desnorte, o necessário. Voltasse sem ela, passava vergonha. Por que tinha assim tentado? Triste em torno. Só as encostas guardando o florir de àrvores esfolhadas: seu roxo-escuro de julho as carobinhas, ipês seu amarelo de agosto. Só via os longes de um quadro. O absurdo ar. Chatos mapas. O céu de se abismar. E indagava o chão, rastreava. Agora, manchava o campo a sombra grande de uma nuvem. O rapaz lançou longe um olhar. De repente, ajustou a mão à testa, e exclamou. Do ponto, descortinou que: aquela. A vaquinha, respoeirando. Aí e lá, tomou-a em vista. O vulto, pé de pessoa, que a cumeada do morro escalava. Ver o que diabo. Reduzida, ocupou, um instante, a lomba linha do espigão. Aí, se afundou para o de lá, e se escondeu de seus olhos. Transcendia ao que se destinava.

O rapaz, durante e tanto, montado no bom cavalo, à espora avante, galgando. Sempre e agudamente olhava. Podia seguir com os olhos como o rastro se formava. Só perseguia a paisagem. Preparava-se uma vastidão: de manchas cinzas e amarelas. O céu também em amarelo. Pitavam extensões de campo, no virar do sol, das quiemadas; altas, mais altas, azuis, as fumaças desmanchavam-se. O rapaz desdobrada vida - se pensou: - "Seja o que seja".

Aî, subia também ao morro, de onde muito se enxergava: antes das portas do longe, as colinas convalares - e um rio, em sua baixadas, em sua várzea empalmeirada. O rio, liso e brilhante, de movimentos invisiveis. Como cortando o mundo em dois, no caminho se atravessava - sem som. Seriam buracos negros, as sombras perto das margens. 
Depois dos destornamentos, a vaquinha chegava à beira, às derradeiras canas-bravas. Com roubada rapidez, ia a levantar o desterro. Foi uma mexidinha figura - quase que mal os dois chifres nadando - a vaca vermelha o transpondo, a esse rio, de tardinha; que em setembro. Sob o céu que recebia a noite, e que as fumaças chamava.

Outrarte o ouro esboço do crepúsculo. O rapaz, o cavalo bom, como vinham, contornando. Antes do rio não viam: as aves, que já ninhavam. À beira, na tardação, não queria desastrar-se, de nada; pensava. Às pausas, parte por parte. Não ouviu sino de vésperas. Tinha de perder de ganhar? Já que sim e já que não, pensou assim: jamais, jamenos... - o filho de seo Rigério. A fatal perseguição, podia quebrar e quitar-se. Hesitou, se. Por certo não passaria, sem o que ele mesmo não o sabia - a oculta, súbita saudade. Passo extremo! Pegou a descalçar as botas. E entrou - de peito feito. Àquelas qüilas águas trans - às braças. Era um rio e seu além. Estava, já, do outro lado.

- “A vaca?" - e apertava o encalço - à boa espora, à rédea larga. Mas a vaca era uma malícia, precipitava-se o logro. Nisso, anoiteceu. E não é que, seu cavalo, o murça, se sentia - da viagem de pêlo a pêlo: os joelhos bambeava, descaía quase caía para a frente o cavaleiro.

Iam-se, na ceguez da noite - à casa da mãe do breu: a vaca, o homem, a vaca - transeuntes, galopando. - "Onde então o Pãodolhão? Cujo dono? Vinha-se a qual destinatário?" Pelas vertentes, distante, e até ao cimo do monte, um campo se incendiava: faiscas - as primeiras estrelas. O andamento. O rapaz: obcego. Sofria como podia, nem podia mais desespero. $\mathrm{O}$ arrepio negro das àrvores. $\mathrm{O}$ mundo entre as estrelas e os grilos. Semiluz: sós estrelas. Onde e aonde? A vaca, essa, sabia: por amor desses lugares.

Chagava, chegavam. Os pastos da vasta fazenda. A vaca surgiase na treva. Mugiu, arrancadamente. Remugiu em fim. A um bago de luz, lá, lá. Às luzes que potilhavam, acolá, as janelas da casa, grande. Só era uma luz de entrequanto? A casa de um Major Quitério. 
O rapaz e a vaca se entravam pela porteira-mestra dos currais. $\mathrm{O}$ rapaz desapeava. Sob o estúrdio atontamento, começou a subir a escada. Tanto tinha de explicar.

Tanto ele era o bem-chegado!

A uma roda de pessoas. Às quatro moças da casa. A uma delas, a segunda. Era alta, alva, amável. Ela se desescondia dele. Inesperavamse? O moço compreendeu-se. Aquilo mudava o acontecido. Da vaca, ele a ela diria: - "É sua." Suas duas almas se transformavam? E tudo à sazão do ser. No mundo nem há parvoíces: o mel do maravilhoso, vindo a tais horas de estórias, o anel dos maravilhados. Amavam-se.

E a vaca - vitória, em seus ondes, por seus passos. 